\title{
Power Technologies Energy Data Book
}

Fourth Edition

NPE National Renewable Energy Laboratory

Prepared for the Office of Energy Efficiency and Renewable Energy
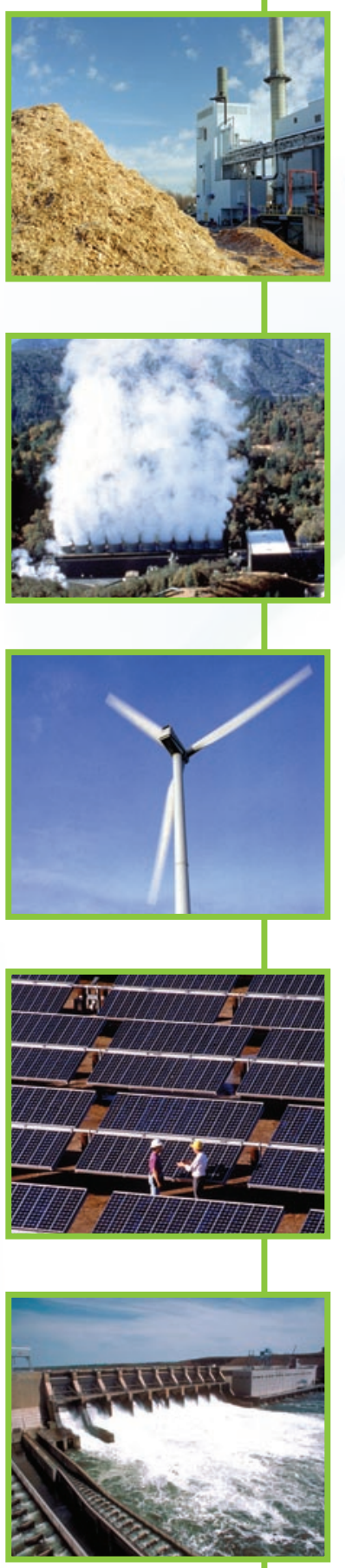

\section{August $2006 \bullet$ NREL/TP-620-39728}




\section{Power Technologies Energy Data Book}

\section{Fourth Edition}

\section{Compiled by J. Aabakken}

Prepared under Task No. WUA3.1000

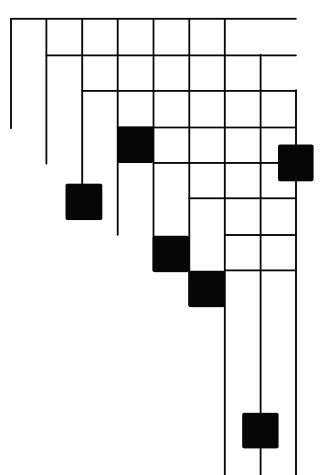




\section{NOTICE}

This report was prepared as an account of work sponsored by an agency of the United States government. Neither the United States government nor any agency thereof, nor any of their employees, makes any warranty, express or implied, or assumes any legal liability or responsibility for the accuracy, completeness, or usefulness of any information, apparatus, product, or process disclosed, or represents that its use would not infringe privately owned rights. Reference herein to any specific commercial product, process, or service by trade name, trademark, manufacturer, or otherwise does not necessarily constitute or imply its endorsement, recommendation, or favoring by the United States government or any agency thereof. The views and opinions of authors expressed herein do not necessarily state or reflect those of the United States government or any agency thereof.

Available electronically at http://www.osti.gov/bridge

Available for a processing fee to U.S. Department of Energy and its contractors, in paper, from:

U.S. Department of Energy

Office of Scientific and Technical Information

P.O. Box 62

Oak Ridge, TN 37831-0062

phone: 865.576.8401

fax: 865.576 .5728

email: mailto:reports@adonis.osti.gov

Available for sale to the public, in paper, from:

U.S. Department of Commerce

National Technical Information Service

5285 Port Royal Road

Springfield, VA 22161

phone: 800.553 .6847

fax: 703.605.6900

email: orders@ntis.fedworld.gov

online ordering: http://www.ntis.gov/ordering.htm 


\section{Table of Contents}

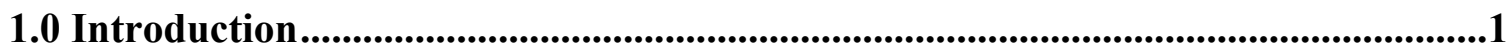

\subsection{Technology Profiles}

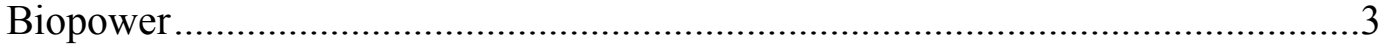

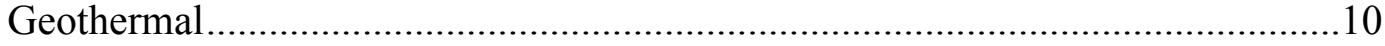

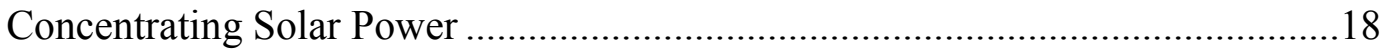

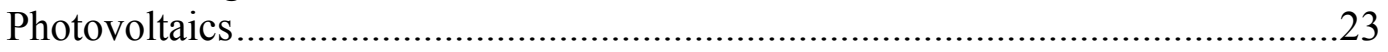

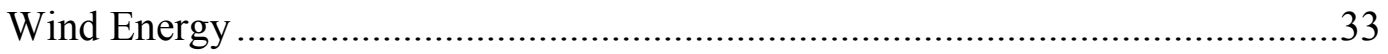

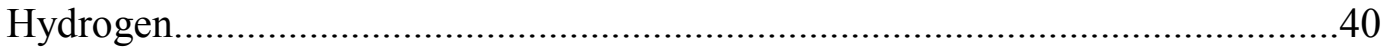

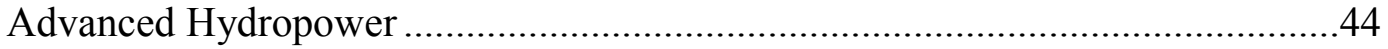

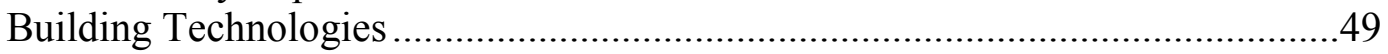

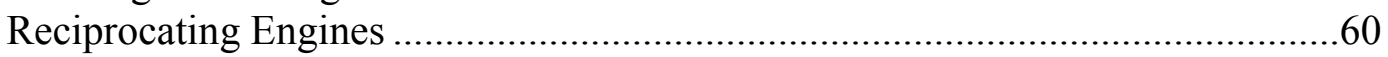

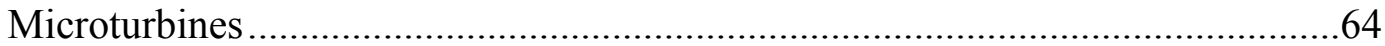

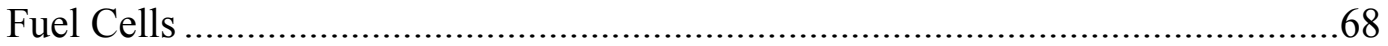

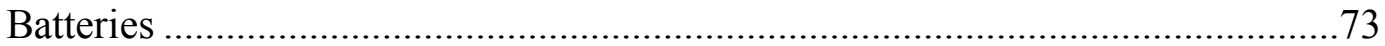

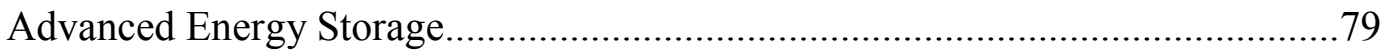

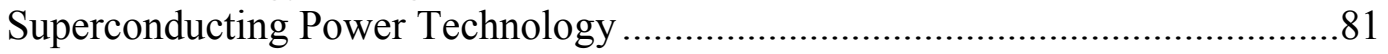

Thermally Activated Technologies ............................................................... 86

\subsection{Electricity Restructuring}

3.1 States with Competitive Electricity Markets .......................................89

3.2 States with System Benefit Charges (SBC) .........................................90

3.3 States with Renewable Portfolio Standards (RPS) .................................93

3.4 States with Net Metering Policies .........................................................99

3.5 States with Environmental Disclosure Policies ..................................... 108

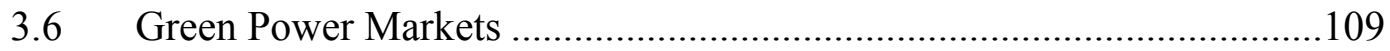

3.7 States with Utility Green Pricing Programs........................................... 112

3.8 Competitive Green Power Offerings and Renewable

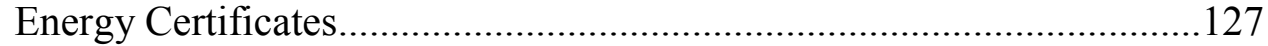

3.9 Federa Agency Purchases of Green Power ........................................... 137

3.10 State Incentive Programs ................................................................. 138

\subsection{Forecasts/Comparisons}

4.1 Projections of Renewable Electricity Net Capacity ...............................143

4.2 Projections of Renewable Electricity Net Generation ........................... 144

4.3 Projections of Renewable Electricity Carbon Dioxide

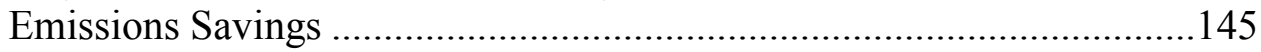

\subsection{Electricity Supply}

$5.1 \quad$ U.S. Total and Delivered Energy (Overview) .....................................147

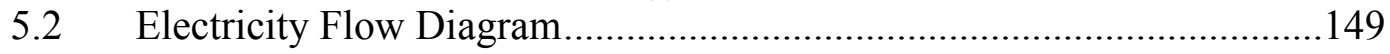

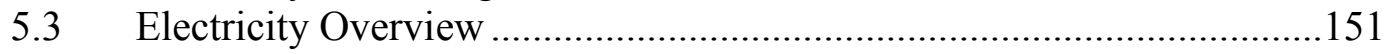

5.4 Consumption of Fossil Fuels by Electric Generators ............................ 152

5.5 Electric Power Sector Energy Consumption ...........................................153 
5.6 Fossil Fuel Generation by Age of Generating Units..............................155

5.7 Nuclear Generation by Age of Generating Units ..................................156

5.8 Operational Renewable Energy Generating Capacity ............................157

5.9 Number of Utilities by Class of Ownership and Nonutilities ..................158

5.10 Top 10 U.S. Investor-Owned Utilities ................................................159

5.11 Top 10 Independent Power Producers Worldwide (2001) .....................160

5.12 Utility Mergers and Acquisitions........................................................... 161

5.13a North American Electric Reliability Council Map for the United States ............................................................................. 162

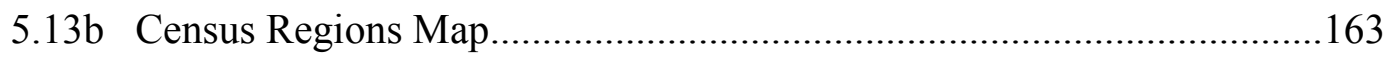

\subsection{Electricity Capability}

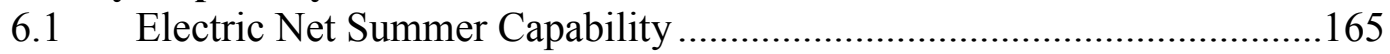

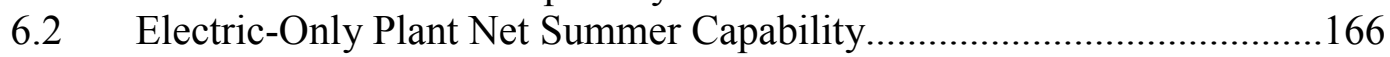

6.3 Combined-Heat-and-Power Plant Net Summer Capability ......................167

6.4 Regional Noncoincident Peak Loads and Capacity Margin .....................168

6.5 Electric Generator Cumulative Additions and Retirements.....................169

6.6 Transmission and Distribution Circuit Miles.....................................170

\subsection{Electricity Generation}

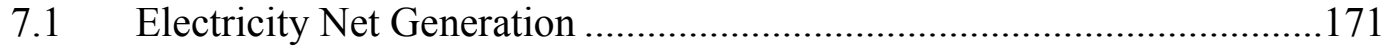

7.2 Net Generation at Electric-Only Plants .............................................172

7.3 Electricity Generation at Combined-Heat-and-Power Plants ..................173

7.4 Generation and Transmission/Distribution Losses ................................. 174

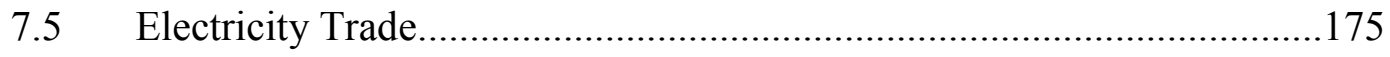

\subsection{Electricity Demand}

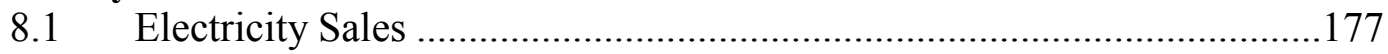

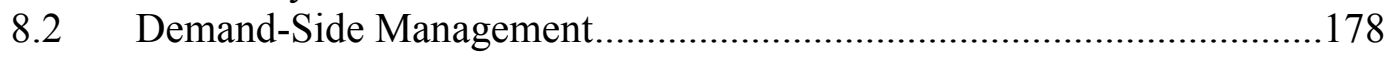

8.3 Electric Utility Sales, Revenue, and Consumption by

Census Division and State .............................................................179

\subsection{Prices}

9.1 Price of Fuels Delivered to Electric Generators ..................................181

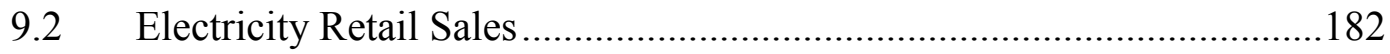

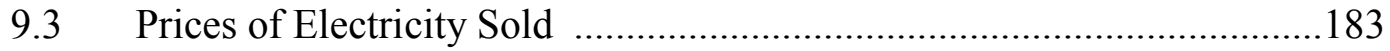

9.4 Revenue from Electric Utility Retail Sales by Sector............................ 184

9.5 Revenue from Sales to Ultimate Consumers by Sector, Census

Division, and State ..................................................................185

9.6 Production, Operation, and Maintenance Expenses for Major U.S. Investor-Owned and Publicly Owned Utilities ....................................187

9.6a Operation and Maintenance Expenses for Major U.S. Investor-Owned Electric Utilities .............................................................................. 188

9.6b Operation and Maintenance Expenses for Major U.S. Publicly Owned Generator and Nongenerator Electric Utilities ....................................189

9.7 Environmental Compliance Equipment Costs ......................................190 


\subsection{Economic Indicators}

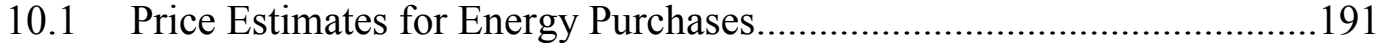

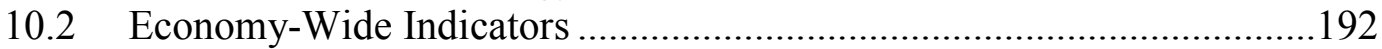

10.3 Composite Statements of Income for Major U.S. Publicly Owned Generator and Investor-Owned Electric Utilities

\subsection{Environmental Indicators}

11.1 Emissions from Electricity Generators

11.2 Installed Nameplate Capacity of Utility Steam-Electric Generators with Environmental Equipment ..................................................................197

11.3 EPA-Forecasted Nitrogen Oxide, Sulfur Dioxide, and Mercury Emissions from Electric Generators

11.4 Origin of 2004 Allowable $\mathrm{SO}_{2}$ Emissions Levels.

\subsection{Conversion Factors}

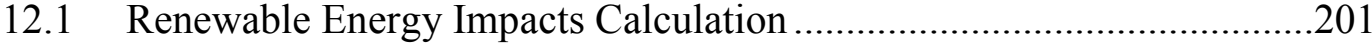

12.2 Number of Home Electricity Needs Met Calculation ..............................202

12.3 Coal Displacement Calculation.............................................................203

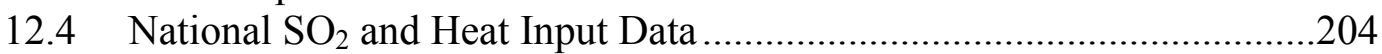

12.5 $\mathrm{SO}_{2}, \mathrm{NO}_{\mathrm{x}}, \mathrm{CO}_{2}$ Emission Factors for Coal-Fired and Noncoal-Fired Title IV Affected Units .....................................................................205

12.6a Sulfur Dioxide, Nitrogen Oxide, and Carbon Dioxide Emission Factors, Electricity Generators .......................................................................206

12.6b Nitrogen Oxide Uncontrolled Emission Factors, Electricity Generators 208

12.6c Uncontrolled Carbon Dioxide Emission Factors, Electricity Generators .....................................................................210

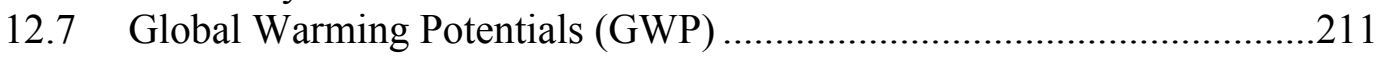

12.8 Approximate Heat Content of Selected Fuels for Electric Power Generation.

12.9 Approximate Heat Rates for Electricity ..........................................213

12.10 Heating Degree Days by Month ..........................................................214

12.11 Cooling Degree Days by Month .........................................................215

13.0 Geographic Information System (GIS) Maps ......................................................217 


\section{1 - Introduction}

About the Power Technologies Energy Data Book (PTEDB), Fourth Edition.

In 2002, the Energy Analysis Office of the National Renewable Energy Laboratory (NREL) developed the first version of the Power Technologies Energy Data Book for the Office of Power Technologies of the U.S. Department of Energy (DOE).

The main purpose of the data book is to compile, in one central document, a comprehensive set of data about power technologies from diverse sources. The need for policy makers and analysts to be well-informed about power technologies suggests the need for a publication that includes a diverse, yet focused, set of data about power technologies.

New for this fourth edition of the PTEDB is Chapter 13, which features Geographic Information System (GIS) maps. One set of maps shows the natural resource (biomass, geothermal, solar, and wind) overlaid with the national transmission grid and the major electricity load centers. The other set of maps shows the current installed capacity (biomass, geothermal, concentrating solar power, and wind), as well as a bar chart indicating the historic trend of generating capacity for the state.

The PTEDB is organized into 13 chapters:

Chapter 1 - Introduction

Chapter 2 - Technology profiles

Chapter 3 - Electricity restructuring

Chapter 4 - Forecasts/comparisons

Chapter 5 - Electricity supply

Chapter 6 - Electricity capability

Chapter 7 - Electricity generation

Chapter 8 - Electricity demand

Chapter 9 - Prices

Chapter 10 - Economic indicators

Chapter 11 - Environmental indicators

Chapter 12 - Conversion factors

Chapter 13 - Geographic Information System (GIS) maps.

The sources used for the Power Technologies Energy Data Book represent the latest available data.

This edition updates the same type of information provided in the previous edition. Most of the data in this publication is taken directly from the source materials, although it may be reformatted for presentation. Neither NREL nor DOE endorses the validity of these data. 
This fourth edition of the Power Technologies Energy Data Book, as well as previous editions, are available on the Internet at http://www.nrel.gov/analysis/power_databook/. The PTEDB may be downloaded as a single PDF file, individual chapters, or table PDF files - selected data also is available as Excel spreadsheets.

The Web site also features energy-conversion calculators and features links to the Transportation Energy Data Book and Buildings Energy Data Book. Readers are encouraged to suggest improvements to the PTEDB through the feedback form on the Web site. 


\section{Biopower}

\section{Technology Description}

Biopower, also called biomass power, is the generation of electric power from biomass resources now usually urban waste wood, crop, and forest residues; and, in the future, crops grown specifically for energy production. Biopower reduces most emissions (including emissions of greenhouse gasesGHGs) compared with fossil fuel-based electricity. Because biomass absorbs $\mathrm{CO}_{2}$ as it grows, the entire biopower cycle of growing, converting to electricity, and regrowing biomass can result in very low $\mathrm{CO}_{2}$ emissions compared to fossil energy without carbon sequestration, such as coal, oil or natural gas. Through the use of residues, biopower systems can even represent a net sink for GHG emissions by avoiding methane emissions that would result from landfilling of the unused biomass.

Representative Technologies for Conversion of Feedstock to Fuel for Power and Heat

- Homogenization is a process by which feedstock is made physically uniform for further processing or for combustion (includes chopping, grinding, baling, cubing, and pelletizing).

- Gasification (via pyrolysis, partial oxidation, or steam reforming) converts biomass to a fuel gas that can be substituted for natural gas in combustion turbines or reformed into $\mathrm{H}_{2}$ for fuel cell applications. - Anaerobic digestion produces biogas that can be used in standard or combined heat and power (CHP) applications. Agricultural digester systems use animal or agricultural waste. Landfill gas also is produced anaerobically.

- Biofuels production for power and heat provides liquid-based fuels such as methanol, ethanol, hydrogen, or biodiesel.

\section{Representative Technologies for Conversion of Fuel to Power and Heat}

- Direct combustion systems burn biomass fuel in a boiler to produce steam that is expanded in a Rankine Cycle prime mover to produce power.

- Cofiring substitutes biomass for coal or other fossil fuels in existing coal-fired boilers.

- Biomass or biomass-derived fuels (e.g. syngas, ethanol, biodiesel) also can be burned in combustion turbines (Brayton cycle) or engines (Otto or Diesel cycle) to produce power.

- When further processed, biomass-derived fuels can be used by fuels cells to produce electricity System Concepts

- CHP applications involve recovery of heat for steam and/or hot water for district energy, industrial processes, and other applications.

- Nearly all current biopower generation is based on direct combustion in small, biomass-only plants with relatively low electric efficiency $(20 \%)$, although total system efficiencies for CHP can approach 90\%. Most biomass direct-combustion generation facilities utilize the basic Rankine cycle for electric-power generation, which is made up of the steam generator (boiler), turbine, condenser, and pump.

- For the near term, cofiring is the most costeffective of the power-only technologies. Large coal steam plants have electric efficiencies near $33 \%$. The highest levels of coal cofiring $(15 \%$ on a heat-input basis) require separate feed preparation and injection systems.

- Biomass gasification combined-cycle plants

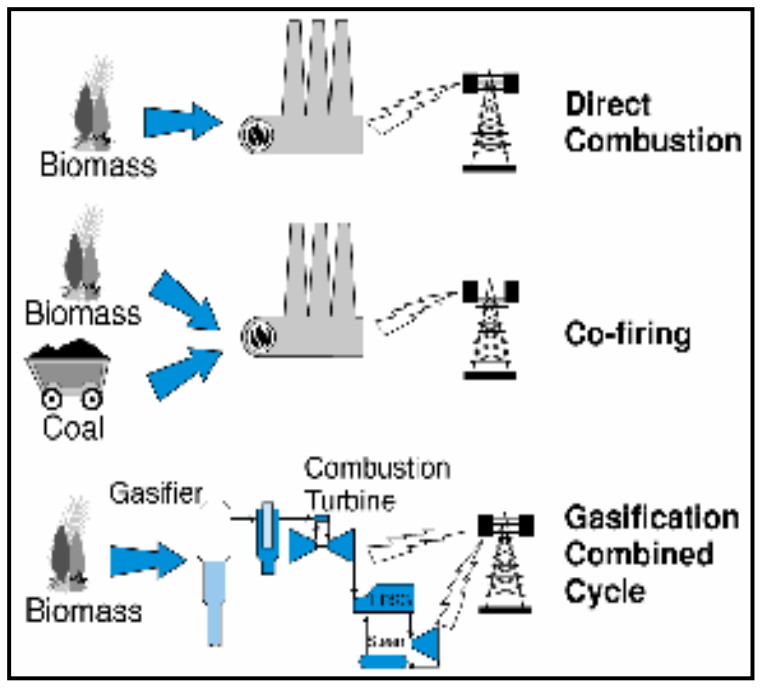
promise comparable or higher electric efficiencies ( $>40 \%)$ using only biomass, because they involve gas turbines (Brayton cycle), which are more efficient than Rankine cycles, as is true for coal. Other technologies being developed include integrated gasification/fuel cell and biorefinery concepts. 


\section{Technology Applications}

- The existing biopower sector - nearly 1,000 plants - is mainly comprised of direct-combustion plants, with an additional small amount of cofiring (six operating plants). Plant size averages $20 \mathrm{MW}_{\mathrm{e}}$, and the biomass-to-electricity conversion efficiency is about $20 \%$. Grid-connected electrical capacity has increased from less than $200 \mathrm{MW}_{\mathrm{e}}$ in 1978 to more than 9,700 $\mathrm{MW}_{\mathrm{e}}$ in 2001 . More than $75 \%$ of this power is generated in the forest products industry's CHP applications for process heat. Wood-fired systems account for close to $95 \%$ of this capacity. In addition, about 3,300 $\mathrm{MW}_{\mathrm{e}}$ of municipal solid waste and landfill gas generating capacity exists. Recent studies estimate that on a life-cycle basis, existing biopower plants represent an annual net carbon sink of 4 MMTCe. Prices generally range from $8 \notin / \mathrm{kWh}$ to $12 \notin / \mathrm{kWh}$.

\section{Current Status}

- CHP applications using a waste fuel are generally the most cost-effective biopower option. Growth is limited by availability of waste fuel and heat demand.

- Biomass cofiring with coal ( $\$ 50-250 / \mathrm{kW}$ of biomass capacity) is the most near-term option for large-scale use of biomass for power-only electricity generation. Cofiring also reduces sulfur dioxide and nitrogen oxide emissions. In addition, when cofiring crop and forest-product residues, GHG emissions are reduced by a greater percentage (e.g. $23 \%$ GHG emissions reduction with $15 \%$ cofiring). - Biomass gasification for large-scale $\left(20-100 \mathrm{MW}_{\mathrm{e}}\right)$ power production is being commercialized. It will be an important technology for cogeneration in the forest-products industries (which project a need for biomass and black liquor CHP technologies with a higher electric-thermal ratio), as well as for new baseload capacity. Gasification also is important as a potential platform for a biorefinery.

- Small biopower and biodiesel systems have been used for many years in the developing world for electricity generation. However, these systems have not always been reliable and clean. DOE is developing systems for village-power applications and for developed-world distributed generation that are efficient, reliable, and clean. These systems range in size from $3 \mathrm{~kW}$ to $5 \mathrm{MW}$ and completed field verification by 2003 .

- Approximately 15 million to 21 million gallons of biodiesel are produced annually in the United States.

- Utility and industrial biopower generation totaled more than 60 billion $\mathrm{kWh}$ in 2001, representing about $75 \%$ of nonhydroelectric renewable generation. About two-thirds of this energy is derived from wood and wood wastes, while one-third of the biopower is from municipal solid waste and landfill gas. Industry consumes more than 2.1 quadrillion Btu of primary biomass energy.

\section{Technology History}

- In the latter part of the $19^{\text {th }}$ century, wood was the primary fuel for residential, commercial, and transportation uses. By the 1950s, other fuels had supplanted wood. In 1973, wood use had dropped to 50 million tons per year.

- At that point, the forest products and pulp-and-paper industries began to use wood with coal in new plants and switched to wood-fired steam power generation.

- The Public Utility Regulatory Policies Act (PURPA) of 1978 stimulated the development of nonutility cogeneration and small-scale plants to in the wood-processing and pulp-and-paper sectors and increased supply of power to the grid.

- The combination of low natural gas prices, improved economies of scale in combined cycle palns, and withdrawal of incentives in the late 1980s, led to annual installations declining from about $600 \mathrm{MW}$ in 1989 , to $300-350 \mathrm{MW}$ in 1990.

- There are now nearly 1,000 wood-fired plants in the United States, with about two-thirds of those providing power (and heat) for on-site uses only. 


\section{Technology Future}

The levelized cost of electricity (in constant $1997 \$ / \mathrm{kWh}$ ) for biomass direct-fired and gasification configurations are projected to be:

$\begin{array}{llll} & \underline{2000} & \underline{2010} & \frac{2020}{7.0} \\ \text { Direct-fired } & 7.5 & & 5.8 \\ \text { Gasification } & 6.7 & 6.1 & 5.4\end{array}$

Source: Renewable Energy Technology Characterizations, EPRI TR-109496, 1997.

- R\&D directions include:

Gasification - This technology requires extensive field verification in order to be adopted by the relatively conservative utility and forest-products industries, especially to demonstrate integrated operation of biomass gasifier with advanced-power generation (turbines and/or fuel cells). Integration of gasification into a biorefinery platform is a key new research area.

Small Modular Systems - Small-scale systems for distributed or minigrid (for premium or village power) applications will be increasingly in demand.

Cofiring - The DOE biopower program is moving away from research on cofiring, as this technology has reached a mature status. However, continued industry research and field verifications are needed to address specific technical and nontechnical barriers to cofiring. Future technology development will benefit from finding ways to better prepare, inject, and control biomass combustion in a coal-fired boiler. Improved methods for combining coal and biomass fuels will maximize efficiency and minimize emissions. Systems are expected to include biomass cofiring up to $5 \%$ of natural gas combined-cycle capacity.

Source: National Renewable Energy Laboratory. U.S. Climate Change Technology Program. Technology Options: For the Near and Long Term. DOE/PI-0002. November 2003 (draft update, September 2005). 


\section{Biomass}

\section{Market Data}

Cumulative Generating Capability, by Type (MW)

\section{U.S. Electric Power Sector} Municipal Solid Waste ${ }^{1}$ Wood and Other Biomass ${ }^{2}$

U.S. Cogenerators ${ }^{3}$ Municipal Solid Waste ${ }^{1}$ Wood and Other Biomass ${ }^{2}$

\section{U.S. Total}

Municipal Solid Waste ${ }^{1}$

Wood and Other Biomass ${ }^{2}$

Biomass Total
Source: Energy Information Administration (EIA), EIA, Annual Energy Review 2004, DOE/EIA-0384(2004) (Washington, D.C., August 2005), Tables 8.11a and 8.11c, and world data from United Nations Development Program, World Energy Assessment, 2000, Table 7.25.

$\begin{array}{rrrrrrrrrrrrr}1980 & 1985 & 1990 & \mathbf{1 9 9 5} & \mathbf{1 9 9 6} & \mathbf{1 9 9 7} & \mathbf{1 9 9 8} & \mathbf{1 9 9 9} & \mathbf{2 0 0 0} & \mathbf{2 0 0 1} & \mathbf{2 0 0 2} & \mathbf{2 0 0 3} & \mathbf{2 0 0 4} \\ & & & & & & & & & & & & \\ \text { N/A } & 151 & 1,852 & 2,733 & 2,600 & 2,528 & 2,636 & 2,614 & 2,789 & 2,993 & 2,949 & 2,842 & 2,856 \\ 78 & 200 & 964 & 1,451 & 1,425 & 1,452 & 1,438 & 1,484 & 1,486 & 1,487 & 1,410 & 1,389 & 1,389 \\ & & & & & & & & & & & & \\ & & & & & & & & & & & & \\ & & 659 & 786 & 998 & 1,062 & 1,058 & 1,046 & 1,094 & 834 & 842 & 961 & 961 \\ & & 4,585 & 5,298 & 5,382 & 5,472 & 5,364 & 5,311 & 4,655 & 4,394 & 4,399 & 4,482 & 4,502 \\ & & & & & & & & & & & & \\ & & & & & & & & & & & & \\ \text { NA } & 151 & 2,511 & 3,519 & 3,598 & 3,590 & 3,694 & 3,660 & 3,883 & 3,827 & 3,845 & 3,803 & 3,817 \\ 78 & 200 & 5,549 & 6,750 & 6,808 & 6,924 & 6,802 & 6,795 & 6,141 & 5,882 & 5,844 & 5,871 & 5,891 \\ 78 & 351 & 8,061 & 10,269 & 10,405 & 10,515 & 10,495 & 10,454 & 10,024 & 9,709 & 9,689 & 9,674 & 9,708\end{array}$

Rest of World Total ${ }^{4}$

World Total

40,000

${ }^{1}$ Municipal solid waste, landfill gas, sludge waste, tires, agricultural byproducts, and other iomass.

${ }^{2}$ Wood, black liquor, and other wood waste.

${ }^{3}$ Data include electric power sector and end-use sector (industrial and commercial) generators.

${ }^{4}$ Number derived from subtracting U.S. total

from the world total. Figures may not add due to rounding. 
U.S. Annual Installed Generating Capability, by Type (MW)

Agricultural Waste $^{2}$

Biogas $^{3}$

Municipal Solid Waste ${ }^{4}$

Wood Residues ${ }^{5}$

Total

U.S. Cumulative Generating Capability, by Type ${ }^{6}$ (MW)

Agricultural Waste $^{2}$

Biogas $^{3}$

Municipal Solid Waste ${ }^{4}$

Wood Residues ${ }^{5}$

Total

Source: Renewable Electric Plant Information System (REPiS), Version 7, NREL, 2003.

$\begin{array}{rrrrrrrrrrrr}1980 & 1985 & 1990 & 1995 & 1996 & 1997 & 1998 & \mathbf{1 9 9 9} & \mathbf{2 0 0 0} & \mathbf{2 0 0 1} & \mathbf{2 0 0 2} & \mathbf{2 0 0 3}^{1} \\ 22.6 & 20.1 & 0 & 4.0 & 0 & 21.6 & 0 & 0 & 0 & 0 & 0 & 0 \\ 0.1 & 58.6 & 51.3 & 17.5 & 74.8 & 92.7 & 87.3 & 107.6 & 43.8 & 66.8 & 30.2 & 23.1 \\ 50.0 & 117.2 & 260.3 & 94.5 & 0 & 0 & 0 & 22.0 & 0 & 0 & 0 & 30.0 \\ 260.4 & 254.8 & 299.4 & 66.5 & 91.6 & 40.0 & 90.3 & 13.0 & 0 & 11.3 & 38.8 & 0 \\ & & & & & & & & & & & \\ 333.0 & 450.7 & 611.0 & 182.5 & 166.4 & 154.3 & 177.6 & 142.6 & 43.8 & 78.1 & 69.0 & 53.1\end{array}$

Source: Renewable Electric Plant Information System (REPiS), Version 7, NREL, 2003.

$\begin{array}{rrrrrrrrrrrr}1980 & 1985 & 1990 & 1995 & \mathbf{1 9 9 6} & \mathbf{1 9 9 7} & \mathbf{1 9 9 8} & \mathbf{1 9 9 9} & \mathbf{2 0 0 0} & \mathbf{2 0 0 1} & \mathbf{2 0 0 2} & \mathbf{2 0 0 3}^{\mathbf{1}} \\ 40 & 92 & 165 & 351 & 351 & 373 & 373 & 373 & 373 & 373 & 373 & 373 \\ 18 & 117 & 361 & 526 & 601 & 694 & 781 & 889 & 933 & 999 & 1,030 & 1,053 \\ 263 & 697 & 2,172 & 2,948 & 2,948 & 2,948 & 2,948 & 2,970 & 2,970 & 2,970 & 2,970 & 3,000 \\ 3,576 & 4,935 & 6,305 & 7,212 & 7,303 & 7,343 & 7,434 & 7,447 & 7,447 & 7,458 & 7,497 & 7,497 \\ & & & & & & & & & & & \\ 3,897 & 5,840 & 9,003 & 11,037 & 11,203 & 11,358 & 11,535 & 11,678 & 11,722 & 11,800 & 11,869 & 11,922\end{array}$

Note: The data in this table does not match data in the previous table, due to different coverage ratios in EIA and REPIS databases.

${ }^{1} 2003$ data not complete as REPiS database is updated through 2002.

${ }^{2}$ Agricultural residues, cannery wastes, nut hulls, fruit pits, nut shells

${ }^{3}$ Biogas, alcohol (includes butahol, ethanol, and methanol), bagasse, hydrogen, landfill gas, livestock manure, wood gas (from wood gasifier)

${ }^{4}$ Municipal solid waste (includes industrial and medical), hazardous waste, scrap tires, wastewater sludge, refused-derived fuel

${ }^{5}$ Timber and logging residues (includes tree bark, wood chips, saw dust, pulping liquor, peat, tree pitch, wood or wood waste)

${ }^{6}$ There are an additional $65.45 \mathrm{MW}$ of Ag Waste, 5.445 MW of Bio Gas, and 483.31 MW of Wood Residues that are not accounted for here because they have no specific online date. 
Generation from

Cumulative Capacity, by

Type (Million kWh)

U.S. Electric Power

Sector

Municipal Solid Wast

Wood and Other Biomass ${ }^{2}$

275

$640 \quad 10,245$

743

5,32

$16,078 \quad 16,397$

$6,493 \quad 6,468$

16,963

6,644

17,112

7,254

7,301

17,221

6,571

17,359

7,265

$8,141 \quad 17,809$

U.S. Cogenerators ${ }^{3}$

Municipal Solid Waste ${ }^{1}$

Wood and Other Biomass ${ }^{2}$

$\begin{array}{rrrr}2,904 & 4,079 & 4,834 & 5,312 \\ 26,939 & 30,636 & 30,307 & 30,480\end{array}$

5,485
29,694

5,460

29,787

5,540

4,543

5,498

5,889

$30,294 \quad 28,629 \quad 31,400$

29,735

4,938

29,820

\section{U.S. Total}

Municipal Solid Waste
Wood and Other Biomass

$\begin{array}{rrrrrr}158 & 640 & 13,149 & 20,405 & 20,911 & 21,709 \\ 275 & 743 & 32,266 & 36,521 & 36,800 & 36,948 \\ 433 & 1,383 & 45,415 & 56,926 & 57,712 & 58,658\end{array}$

$\begin{array}{ll}22,448 & 22,572 \\ 36,338 & 37,041 \\ 58,786 & 59,613\end{array}$

23,131

21,765

22,857

23,736

22,747

$37,595 \quad 35,200 \quad 38,665 \quad 37,529 \quad 37,295$

Biomass Total

\section{Rest of World Total ${ }^{4}$}

101,214

World Total

160,000

${ }^{1}$ Municipal solid waste, landfill gas, sludge waste, tires, agricultural byproducts, and other biomass.

${ }^{2}$ Wood, black liquor, and other wood waste.

${ }^{3}$ Data include electric power sector and end-use sector (industrial and commercial) generators.

${ }^{4}$ Number derived from subtracting U.S. total from the world total. Figures may not add due to rounding.

\section{U.S. Annual Energy}

Consumption for Electricity

Generation (Trillion Btu)

Electric-Power Sector
Commercial Sector ${ }^{1}$
Industrial Sector $^{1}$
Total Biomass

\begin{tabular}{|c|c|c|c|c|c|c|c|c|c|c|c|c|}
\hline 1980 & 1985 & 1990 & 1995 & 1996 & 1997 & 1998 & 1999 & 2000 & 2001 & 2002 & 2003 & 2004 \\
\hline \multirow[t]{3}{*}{4.5} & 14.4 & 285.9 & 388.0 & 397.3 & 408.3 & 412.0 & 415.5 & 420.7 & 430.4 & 494.1 & 493.1 & 492.4 \\
\hline & & 16.7 & 22.3 & 32.1 & 34.3 & 32.7 & 33.5 & 26.5 & 22.6 & 28.5 & 30.6 & 32.2 \\
\hline & & 351.0 & 385.3 & 407.1 & 380.7 & 362.0 & 373.0 & 378.8 & 379.6 & 481.5 & 378.7 & 567.8 \\
\hline 4.5 & 14.4 & 653.5 & 795.6 & 836.5 & 823.3 & 806.8 & 822.0 & 825.9 & 832.6 & $1,004.1$ & 902.4 & $1,092.4$ \\
\hline
\end{tabular}

Data include wood (wood, black liquor, and other wood waste) and waste (municipal solid waste, landfill gas, sludge waste, tires, agricultural byproducts, and other biomass).

${ }^{1}$ Data includes combined-heat-and-power (CHP) and electricity-only plants.

Source: EIA, Annual Energy Review 2004, Tables 8.4b and 8.4c 
Technology Performance

Source: Renewable Energy Technology Characterizations, EPRI TR-109496, 1997.

\begin{tabular}{|c|c|c|c|c|c|c|c|c|c|}
\hline Efficiency & & 1980 & 1990 & $1995^{1}$ & 2000 & 2005 & 2010 & $2015^{2}$ & 2020 \\
\hline \multirow[t]{3}{*}{ Capacity Factor (\%) } & Direct-fired & & & 80.0 & 80.0 & 80.0 & 80.0 & 80.0 & 80.0 \\
\hline & Cofired & & & 85.0 & 85.0 & 85.0 & 85.0 & 85.0 & 85.0 \\
\hline & Gasification & & & 80.0 & 80.0 & 80.0 & 80.0 & 80.0 & 80.0 \\
\hline \multirow[t]{3}{*}{ Efficiency $(\%)$} & Direct-fired & & & 23.0 & 27.7 & 27.7 & 27.7 & 30.8 & 33.9 \\
\hline & Cofired & & & 32.7 & 32.5 & 32.5 & 32.5 & 32.5 & 32.5 \\
\hline & Gasification & & & 36.0 & 36.0 & 37.0 & 37.0 & 39.3 & 41.5 \\
\hline \multirow[t]{3}{*}{ Net Heat Rate $(\mathrm{kJ} / \mathrm{kWh})$} & Direct-fired & & & 15,280 & 13,000 & 13,000 & 13,000 & 11,810 & 10,620 \\
\hline & Cofired & & & 11,015 & 11,066 & 11,066 & 11,066 & 11,066 & 11,066 \\
\hline & Gasification & & & 10,000 & 10,000 & 9,730 & 9,730 & 9,200 & 8,670 \\
\hline Cost & & 1980 & 1990 & $1995^{1}$ & 2000 & 2005 & 2010 & 2015 & 2020 \\
\hline \multirow[t]{3}{*}{ Total Capital Cost $(\$ / \mathrm{kW})$} & Direct-fired & & & 1,965 & 1,745 & 1,510 & 1,346 & 1,231 & 1,115 \\
\hline & Cofired $^{3}$ & & & 272 & 256 & 241 & 230 & 224 & 217 \\
\hline & Gasification & & & 2,102 & 1,892 & 1,650 & 1,464 & 1,361 & 1,258 \\
\hline \multirow[t]{3}{*}{ Feed Cost (\$/GJ) } & Direct-fired & & & 2.50 & 2.50 & 2.50 & 2.50 & 2.50 & 2.50 \\
\hline & Cofired $^{3}$ & & & -0.73 & -0.73 & -0.73 & -0.73 & -0.73 & -0.73 \\
\hline & Gasification & & & 2.50 & 2.50 & 2.50 & 2.50 & 2.50 & 2.50 \\
\hline \multirow[t]{4}{*}{ Fixed Operating Cost $(\$ / k W-y r)$} & Direct-fired & & & 73.0 & 60.0 & 60.0 & 60.0 & 54.5 & 49.0 \\
\hline & Cofired $^{3}$ & & & 10.4 & 10.1 & 9.8 & 9.6 & 9.5 & 9.3 \\
\hline & Gasification & & & 68.7 & 43.4 & 43.4 & 43.4 & 43.4 & 43.4 \\
\hline & & 1980 & 1990 & $1995^{1}$ & 2000 & 2005 & 2010 & 2015 & 2020 \\
\hline \multirow{3}{*}{ Variable Operating Costs ( $\$ / \mathrm{kWh})$} & Direct-fired & & & 0.009 & 0.007 & 0.007 & 0.007 & 0.006 & 0.006 \\
\hline & Cofired $^{3}$ & & & -0.002 & -0.002 & -0.002 & -0.002 & -0.002 & -0.002 \\
\hline & Gasification & & & 0.004 & 0.004 & 0.004 & 0.004 & 0.004 & 0.004 \\
\hline \multirow[t]{3}{*}{ Total Operating Costs (\$/kWh) } & Direct-fired & & & 0.055 & 0.047 & 0.047 & 0.047 & 0.043 & 0.039 \\
\hline & Cofired $^{3}$ & & & -0.008 & -0.008 & -0.008 & -0.009 & -0.009 & -0.009 \\
\hline & Gasification & & & 0.040 & 0.036 & 0.036 & 0.036 & 0.034 & 0.033 \\
\hline \multirow[t]{3}{*}{ Levelized Cost of Energy ( $\$ / \mathrm{kWh})$} & Direct-fired & & & 0.087 & 0.075 & & 0.070 & & 0.058 \\
\hline & Cofired $^{3}$ & & & $\mathrm{~N} / \mathrm{A}$ & $\mathrm{N} / \mathrm{A}$ & $\mathrm{N} / \mathrm{A}$ & N/A & $\mathrm{N} / \mathrm{A}$ & $\mathrm{N} / \mathrm{A}$ \\
\hline & Gasification & & & 0.073 & 0.067 & & 0.061 & & 0.054 \\
\hline
\end{tabular}

Data is for 1997, the base year of the Renewable Energy Technology Characterizations analysis.

${ }^{2}$ Number derived by interpolation.

${ }^{3}$ Note that cofired cost characteristics represent only the biomass portion of costs for capital and incremental costs above conventional costs for Operations \& Maintenance (O\&M), and assume $\$ 9.14 / \mathrm{dry}$ tonne biomass and $\$ 39.09 /$ tonne coal, a heat input from biomass at $19,104 \mathrm{~kJ} / \mathrm{kg}$, and that variable O\&M includes an SO2 credit valued at $\$ 110 /$ tonne SO2. No cofiring COE is reported in the RETC. 


\section{Geothermal Energy}

\section{Technology Description}

Geothermal energy is heat from within the Earth. Hot water or steam are used to produce electricity or applied directly for space heating and industrial processes. This energy can offset the emission of carbon dioxide from conventional fossil-powered electricity generation, industrial processes, building thermal systems, and other applications.

\section{System Concepts}

- Geophysical, geochemical, and geological exploration locates resources to drill, including highly permeable hot reservoirs, shallow warm groundwater, hot impermeable rock masses, and highly pressured hot fluids.

- Well fields and distribution systems allow the hot fluids to move to the point of use, and afterward, back to the earth.

- Utilization systems may apply the heat directly or convert it to another form of energy such as electricity.

\section{Representative Technologies}

- Exploration technologies identify geothermal reservoirs and their fracture

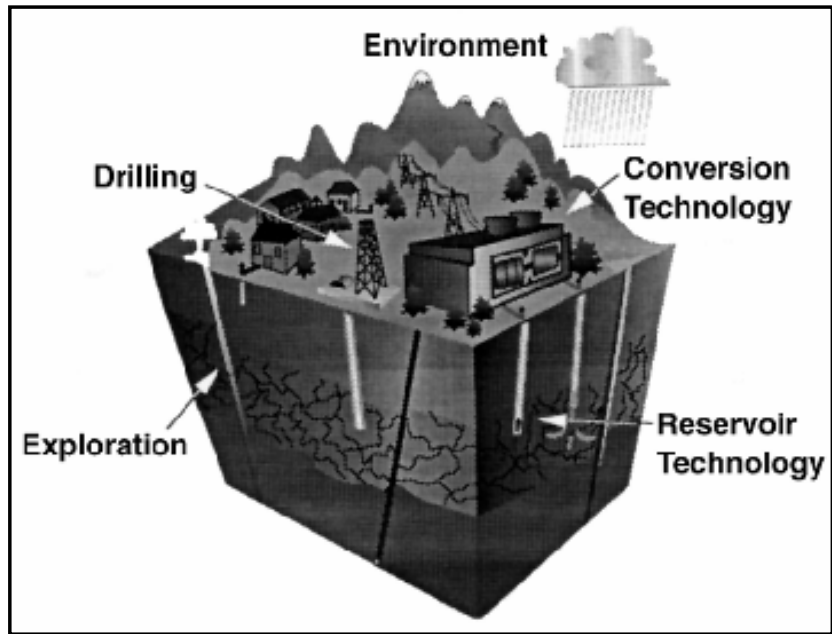
systems; drilling, reservoir testing, and modeling optimize production and predict useful lifetime; steam turbines use natural steam or hot water flashed to steam to produce electricity; binary conversion systems produce electricity from water not hot enough to flash.

- Direct applications use the heat from geothermal fluids without conversion to electricity. Geothermal heat pumps use the shallow earth as a heat source and heat sink for heating and cooling applications.

- Coproduction, the recovery of minerals and metals from geothermal brine, is being pursued. Zinc is recovered at the Salton Sea geothermal field in California.

\section{Technology Applications}

- With improved technology, the United States has a resource base capable of producing up to 100 $\mathrm{GW}$ of electricity at less than $5 \varnothing / \mathrm{kWh}$.

- Hydrothermal reservoirs are being used to produce electricity with an online availability of up to 97\%; advanced energy-conversion technologies are being implemented to improve plant thermal efficiency.

- Direct-use applications are successful throughout the western United States and provide heat for space heating, aquaculture, greenhouses, spas, and other applications.

- Geothermal heat pumps continue to penetrate markets for heating/cooling (HVAC) services.

\section{Current Status}

- The DOE Geothermal Program sponsored research that won two R\&D 100 Awards in 2003: Acoustic Telemetry Technology, which provides a high speed data link between the surface and the drill bit; and Low Emission Atmospheric Monitoring Separator, which safely contains and cleans vented steam during drilling, well testing, and plant start-up.

- A second pipeline to carry replacement water has been completed through the joint efforts of industry and federal, state, and local agencies. This will increase production and extend the lifetime of The Geysers Geothermal Field in California. The second pipeline adds $85 \mathrm{MW}$ of capacity. 


\section{Technology History}

- The use of geothermal energy as a source of hot water for spas dates back thousands of years.

- In 1892, the world's first district heating system was built in Boise, Idaho, as water was piped from hot springs to town buildings. Within a few years, the system was serving 200 homes and 40 downtown businesses. Today, the Boise district heating system continues to flourish. Although no one imitated this system for nearly 70 years, there are now 17 district heating systems in the United States and dozens more around the world.

- The United States' first geothermal power plant went into operation in 1922 at The Geysers in California. The plant was $250 \mathrm{~kW}$, but fell into disuse.

- In 1960, the country's first large-scale geothermal electricity-generating plant began operation. Pacific Gas and Electric operated the plant, located at The Geysers. The resource at The Geysers is dry steam. The first turbine produces 11 megawatts (MW) of net power and operated successfully for more than 30 years.

- In 1979, the first electrical development of a water-dominated geothermal resource occurred at the East Mesa field in the Imperial Valley in California.

- In 1980, UNOCAL built the country's first flash plant, generating $10 \mathrm{MW}$ at Brawley, California.

- In 1981, with a supporting loan from DOE, Ormat International Inc. successfully demonstrated binary technology in the Imperial Valley of California. This project established the technical feasibility of larger-scale commercial binary power plants. The project was so successful that Ormat repaid the loan within a year.

- By the mid-1980s, electricity was being generated by geothermal power in four western states: California, Hawaii, Utah, and Nevada.

- In the 1990s, the U.S. geothermal industry focused its attention on building power plants overseas, with major projects in Indonesia and the Philippines.

- In 1997, a pipeline began delivering treated municipal wastewater and lake water to The Geysers steamfield in California, increasing the operating capacity by $70 \mathrm{MW}$.

- In 2000, DOE initiated its GeoPowering the West program to encourage development of geothermal resources in the western United States by reducing nontechnical barriers.

- The DOE Geothermal Program sponsored research that won two R\&D awards in 2003, advancing this renewable energy.

- With approval of the federal production tax credit and with support from state-level renewable portfolio standards, U.S. geothermal power is poised to double in capacity within the next couple of years.

\section{Technology Future}

The levelized cost of electricity (in constant $1997 \$ / \mathrm{kWh}$ ) for the two major future geothermal energy configurations are projected to be:

$\begin{array}{llll} & \frac{2000}{3.0} & \frac{2010}{2.4} & \frac{2020}{2.1} \\ \text { Hydrothermal Flash } & 3.6 & 2.9 & 2.7\end{array}$

Source: Renewable Energy Technology Characterizations, EPRI TR-109496, 1997.

- Costs at the best sites are competitive at today's energy prices - and investment is limited by uncertainty in prices; lack of new, confirmed resources; high front-end costs; and lag time between investment and return.

- Improvements in cost and accuracy of resource exploration and characterization can lower the electricity cost; demonstration of new resource concepts, such as enhanced geothermal systems, would allow a large expansion of the U.S. use of hydrothermal when economics become favorable. 


\section{Market Context}

- Hydrothermal reservoirs have an installed capacity of about 2,133 MW electric in the United States and about 8,000 MW worldwide. Direct-use applications have an installed capacity of about $600 \mathrm{MW}$ thermal in the United States. About 300 MW electric are being developed in California, Nevada, and Idaho.

- Geothermal will continue production at existing plants $(2.1 \mathrm{GW})$ with future construction potential (100 GW by 2040). Direct heat will replace existing systems in markets in 19 western states.

- By 2015, geothermal could provide about $10 \mathrm{GW}$, enough heat and electricity for 7 million homes; by 2020 , an installed electricity capacity of 20,000 MW from hydrothermal plants and 20,000 MW from enhanced geothermal systems is projected.

Source: National Renewable Energy Laboratory. U.S. Climate Change Technology Program. Technology Options: For the Near and Long Term. DOE/PI-0002. November 2003 (draft update, September 2005). 


\section{Geothermal}

\section{Market Data}

Cumulative Installed

Capacity

\section{Electricity $\left(\mathrm{MW}_{\mathrm{e}}\right)$}

U.S.

Rest of World

World Total

Direct-Use Heat $\left(\mathrm{MW}_{\mathrm{th}}\right)$

U.S.

Rest of World

World Total

Cumulative Installed

Capacity

Electricity $\left(\mathrm{MW}_{\mathrm{e}}\right)$

U.S.

Rest of World

World Total

Direct-Use Heat $\left(\mathrm{MW}_{\mathrm{th}}\right)$

U.S.

Rest of World

World Total
Source: U.S. electricity data from EIA, Annual Energy Review 2004, DOE/EIA-0384(2004) (Washington, D.C., August 2005), Table 8.11a; world totals from Renewable Energy World/July-August 2000, page 123, Table 1; 1998 world totals from UNDP World Energy Assessment 2000, Tables 7.20 and 7.25; 1997 world electricity and U.S. and world direct-use heat data from Stefansson and Fridleifsson 1998, "Geothermal Energy: European and World-wide Perspective."

$\begin{array}{llllllll}1985 & 1990 & 1995 & 1996 & 1997 & 1998 & 1999 & 2000\end{array}$

$20012002 \quad 2003$

2004

$\begin{array}{rrrrrrrrr}909 & 1,580 & 2,666 & 2,968 & 2,893 & 2,893 & 2,893 & 2,846 & 2,793 \\ 1,191 & 3,184 & 3,166 & 3,829 & & 5,128 & 5,346 & & 5,181 \\ 2,100 & 4,764 & 5,832 & 6,797 & & 8,021 & 8,239 & & 7,974\end{array}$

2,21

$2,252 \quad 2,133$ $\begin{array}{lll}3,184 & 3,166 & 3,829 \\ 4,764 & 5,832 & 6,797\end{array}$

7,974

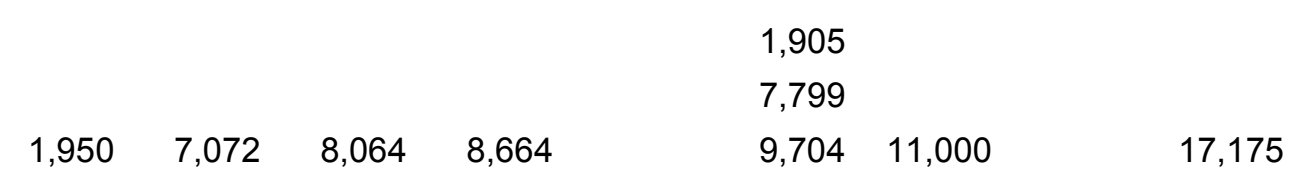

Source: International Geothermal Association, http://iga.igg.cnr.it/index.php

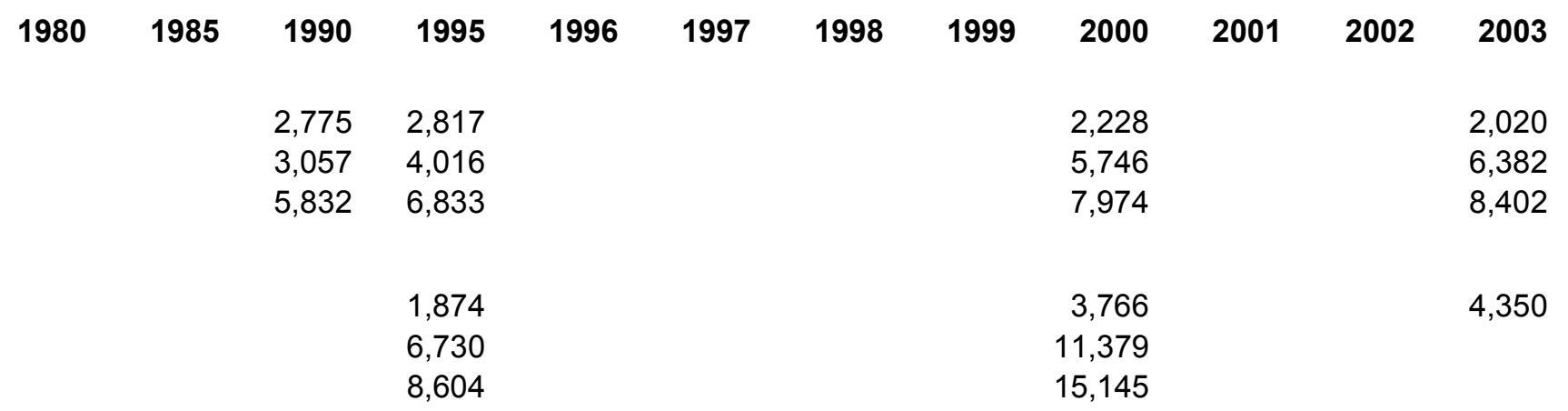


Annual Installed Electric Capacity $\left(\mathrm{MW}_{\mathrm{e}}\right)$

U.S.

Source: Renewable Electric Plant Information System (REPiS), Version 7, NREL, 2003.

\begin{tabular}{rrrrrrrrrrrr}
1980 & 1985 & 1990 & 1995 & 1996 & 1997 & 1998 & 1999 & 2000 & 2001 & 2002 & $2^{2003}$ \\
251.0 & 352.9 & 48.6 & & 36.0 & & & & 59.9 & & & \\
\hline
\end{tabular}

Cumulative Installed Electric Source: Renewable Electric Plant Information System (REPiS), Version 7, NREL, 2003.

Capacity $\left(\mathrm{MW}_{\mathrm{e}}\right)$

\begin{tabular}{lrrrrrrrrrrrrr} 
& 1980 & 1985 & 1990 & 1995 & 1996 & 1997 & 1998 & 1999 & 2000 & $\mathbf{2 0 0 1}$ & $\mathbf{2 0 0 2}$ & $\mathbf{2 0 0 3}$ \\
U.S. & 802 & 1,698 & 2,540 & 2,684 & 2,720 & 2,720 & 2,720 & 2,720 & 2,779 & 2,779 & 2,779 & 2,779 \\
\hline
\end{tabular}

* 2003 data not complete as REPiS database is updated through 2002.

Installed Capacity and Power Source: Lund and Freeston, World-Wide Direct Uses of Geothermal Energy 2000, Lund and Boyd, Geothermal DirectGeneration/Energy Production Use in the United States Update: 1995-1999, J. Lund, World Status of Geothermal Energy Use Overview 1995-1999 from Installed Capacity http://www.geothermie.de/europaundweltweit/Lund/wsoge_index.htm, Sifford and Blommquist, Geothermal Electric Power Production in the United States: A Survey and Update for 1995-1999, and G. Huttrer, The Status of World Geothermal Power Generation 1995-2000. Proceedings of the World Geothermal Congress 2000 http://geothermal.stanford.edu/wgc2000/SessionList.htm, Kyushu-Tohoku, Japan, May 28-June10, 2000.

Cumulative Installed Capacity

\section{Electricity $\left(\mathrm{MW}_{\mathrm{e}}\right)$}

U.S.

Rest of World

World Total

Direct-Use Heat* $\left(\mathrm{MW}_{\text {th }}\right)$

U.S.

Rest of World

World Total
1980

1985

1990

1995

1996

2,369

4,464

3,887

4,764

5,832

6,833

2,343

1997

1998

1999

2000

2,228

5,746

7,974

4,200

12,975

$1,950 \quad 7,072 \quad 8,064 \quad 8,664$

17,175 
Annual Generation/Energy Production from Cumulative Installed Capacity

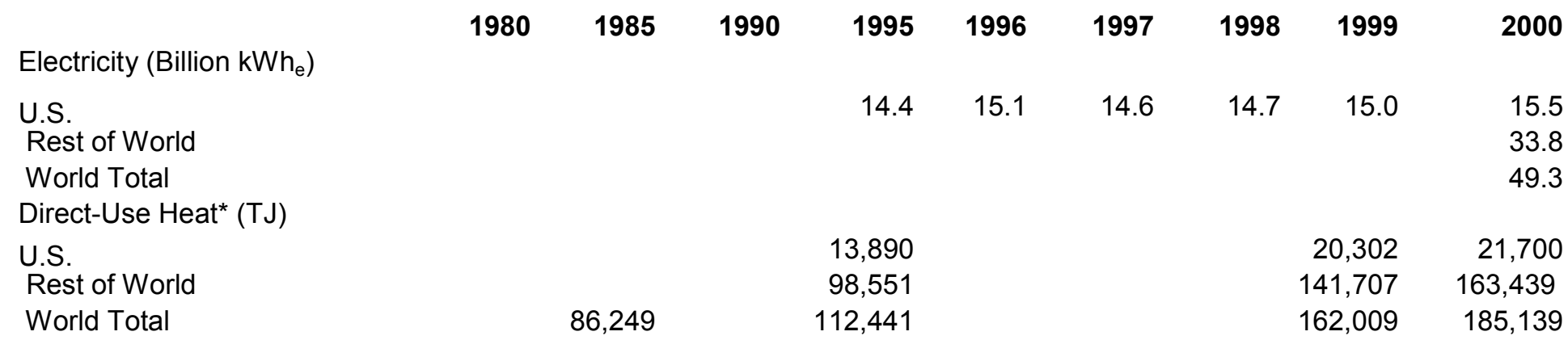

* Direct-use heat includes geothermal heat pumps as well as traditional uses. Geothermal heat pumps account for 1854 MW $6849 \mathrm{MW}_{\text {th }}(23,214 \mathrm{TJ})$ in 1999 of the world totals and $3600 \mathrm{MW}_{\text {th }}(8,800 \mathrm{TJ})$ in 2000 of the U.S. total. Conversion of GWh to TJ is done at 1TJ = $0.2778 \mathrm{GWh}$.

Annual Generation from Source: U.S. electricity data from EIA, Annual Energy Review 2004, DOE/EIA-0384(2004) (Washington, D.C., Cumulative Installed Capacity August 2005), Table 8.2a; world electricity totals from Renewable Energy World/July-August 2000, page 126, Table 2; 1997 world electricity and U.S. and world direct-use heat data from Stefansson and Fridleifsson 1998, "Geothermal Energy: European and World-wide Perspective." 1998 world totals from UNDP World Energy Assessment 2000, Table 7.25; 1995, 2000, and 2003 direct-use heat and 1999 electricity world total from International Geothermal Association, http://iga.igg.cnr.it/index.php.

Electricity (Billion $\mathrm{kWh}_{\mathrm{e}}$ )

19851990

1995

19961997

1998

19992000

2001

20022003

2004

U.S.

Rest of World

$\begin{array}{rrrrrrrrr}5.1 & 9.3 & 15.4 & 13.4 & 14.3 & 14.7 & 14.8 & 14.8 & 14.1 \\ 8.9 & 7.7 & 3.6 & 6.6 & & 29.0 & 31.2 & & 35.2 \\ 14 & 17 & 19 & 20 & & 43.8 & 46 & 49 & 49.3\end{array}$

Direct-Use Heat (billion kWhth)

U.S.

4.0

5.6

$13.7 \quad 14.5 \quad 14.4$

Rest of World

World Total

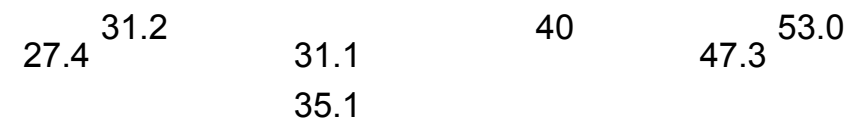


Annual Geothermal Energy

Consumption for Electric Generation

(Trillion Btu)

U.S.

Rest of World

World Total

Annual U.S. Geothermal Heat Pump Shipments, by type (units)

\section{ARI-320}

ARI-325/330

Other non-ARI Rated

Totals

* No survey was conducted for 2001 .

Capacity of U.S. Heat Pump Shipments (Rated Tons)

\section{ARI-320}

ARI-325/330

Other non-ARI Rated

Totals

1 One Rated Ton of Capacity equals 12,000 Btu's.

2 No survey was conducted for 2001.

Annual U.S. Geothermal Heat Pump Shipments by Customer Type and Model Type (units)

\section{Exporter}

Wholesale Distributor

Retail Distributor

Installer
Source: EIA, Annual Energy Review 2004, DOE/EIA-0384(2004) (Washington, D.C., August 2005), Table 8.4a.

$\begin{array}{rrrrrrrrrrrrr}1980 & 1985 & 1990 & 1995 & 1996 & 199 & 1998 & 1999 & 2000 & 2001 & 2002 & 2003 & 2004 \\ 110 & 198 & 326 & 280 & 300 & 309 & 311 & 312 & 296 & 289 & 305 & 303 & 302\end{array}$

Source: EIA, Renewable Energy Annual 2004, DOE/EIA-0603(2004) (Washington, D.C., June 2006), Table 58.

$\begin{array}{rrrrrrrrrrr} & & \mathbf{1 9 9 6} & \mathbf{1 9 9 7} & \mathbf{1 9 9 8} & \mathbf{1 9 9 9} & \mathbf{2 0 0 0} & \mathbf{2 0 0 1}^{*} & \mathbf{2 0 0 2} & \mathbf{2 0 0 3} & \mathbf{2 0 0 4} \\ & 4,696 & 4,697 & 7,772 & 10,510 & 7,910 & 7,808 & \text { N/A } & 6,445 & 10,306 & 9,130 \\ & 26,800 & 25,697 & 28,335 & 26,042 & 31,631 & 26,219 & \text { N/A } & 26,802 & 25,211 & 31,855 \\ 1995 & 838 & 991 & 1,327 & 1,714 & 2,138 & 1,554 & \text { N/A } & 3,892 & 922 & 2,821 \\ & 32,334 & 31,385 & 37,434 & 38,266 & 41,679 & 35,581 & \text { N/A } & 37,139 & 36,439 & 43,806\end{array}$

Source: EIA, Renewable Energy Annual 2004, DOE/EIA-0603(2004) (Washington, D.C., June 2006), Table 59.

\begin{tabular}{|c|c|c|c|c|c|c|c|c|c|}
\hline & 1996 & 1997 & 1998 & 1999 & 2000 & $2001^{*}$ & 2002 & 2003 & 2004 \\
\hline 13,120 & 15,060 & 24,708 & 35,776 & 27,970 & 26,469 & $\mathrm{~N} / \mathrm{A}$ & 16,756 & 29,238 & 23,764 \\
\hline 113,925 & 92,819 & 110,186 & 98,912 & 153,947 & 130,132 & $\mathrm{~N} / \mathrm{A}$ & 96,541 & 89,731 & 100,317 \\
\hline 3,935 & 5,091 & 6,662 & 6,758 & 9,735 & 7,590 & $\mathrm{~N} / \mathrm{A}$ & 12,000 & 5,469 & 20,220 \\
\hline 130,980 & 112,970 & 141,556 & 141,446 & 191,652 & 164,191 & N/A & 125,297 & 124,438 & 144,301 \\
\hline
\end{tabular}

Source: EIA, Renewable Energy Annual 2004, DOE/EIA-0603(2003) (Washington, D.C., June 2006), Table 61, REA 2003 Table 40, REA 2002 Table 40, REA 2001 Table 40, REA 2000 Table 38, REA 1999 Table 38, and REA 1998 Table 40.

$\begin{array}{rrrrrrrrr}1996 & 1997 & \mathbf{1 9 9 8} & \mathbf{1 9 9 9} & \mathbf{2 0 0 0} & \mathbf{2 0 0 1}^{*} & \mathbf{2 0 0 2} & \mathbf{2 0 0 3} & \mathbf{2 0 0 4} \\ 2,276 & 226 & 109 & 6,172 & 784 & \mathrm{~N} / \mathrm{A} & 1,165 & 945 & 1,092 \\ 21,444 & 29,181 & 14,377 & 9,193 & 9,804 & \text { N/A } & 20,888 & 16,167 & 23,647 \\ 8,336 & 829 & 3,222 & 2,555 & 2,272 & \text { N/A } & 552 & 1,145 & 355 \\ 18,762 & 25,302 & 18,429 & 24,917 & 20,491 & \text { N/A } & 10,999 & 10,784 & 13,562\end{array}$




$\begin{array}{lrrrrrrrrr}\text { End User } & 689 & 657 & 994 & 66 & 63 & \text { N/A } & 207 & 1,103 & 397 \\ \text { Others } & 13 & 1,727 & 1,135 & 6,259 & 2,167 & \text { N/A } & 3,328 & 6,295 & 4,753 \\ \text { Total } & 51,520 & 57,922 & 38,266 & 49,162 & 35,581 & \text { N/A } & 37,139 & 36,439 & 43,806\end{array}$

Annual U.S. Geothermal Heat Pump Shipments by Export \& Census Region (units)

Export

Midwest

Northeast

South

West

Total
Source: EIA, Renewable Energy Annual 2004, DOE/EIA-0603(2003) (Washington, D.C., June 2006), Table 60, REA 2003 Table 39, REA 2002 Table 39, REA 2001 Table 39, REA 2000 Table 37, REA 1999 Table 37, and REA 1998 Table 39.

$\begin{array}{rrrrrrrrr}\mathbf{1 9 9 6} & \mathbf{1 9 9 7} & \mathbf{1 9 9 8} & \mathbf{1 9 9 9} & \mathbf{2 0 0 0} & \mathbf{2 0 0 1}^{*} & \mathbf{2 0 0 2} & \mathbf{2 0 0 3} & \mathbf{2 0 0 4} \\ 4,090 & 2,427 & 481 & 6,303 & 1,220 & \text { N/A } & 3,271 & 2,764 & 2,984 \\ 11,874 & 13,402 & 12,240 & 13,112 & 10,749 & \text { N/A } & 12,982 & 12,042 & 14,650 \\ 6,417 & 9,280 & 5,403 & 6,044 & 4,138 & \text { N/A } & 3,903 & 5,924 & 8,060 \\ 25,302 & 26,788 & 16,195 & 20,935 & 17,403 & \text { N/A } & 13,660 & 12,543 & 14,674 \\ 3,837 & 6,025 & 3,947 & 2,768 & 2,071 & \text { N/A } & 3,323 & 3,166 & 3,438 \\ 51,520 & 57,922 & 38,266 & 49,162 & 35,581 & \text { N/A } & 37,139 & 36,439 & 43,806\end{array}$

\section{Technology Performance}

\begin{tabular}{|c|c|c|c|c|c|c|c|c|c|}
\hline \multirow[b]{2}{*}{ Efficiency } & \multicolumn{9}{|c|}{ Source: Renewable Energy Technology Characterizations, EPRI TR-109496, 1997.} \\
\hline & & 1980 & 1990 & 1995 & 2000 & 2005 & 2010 & 2015 & 2020 \\
\hline \multirow[t]{3}{*}{ Capacity Factor (\%) } & Flashed Steam & & & 89 & 92 & 93 & 95 & 96 & 96 \\
\hline & Binary & & & 89 & 92 & 93 & 95 & 96 & 96 \\
\hline & Hot Dry Rock & & & 80 & 81 & 82 & 83 & 84 & 85 \\
\hline Cost & & 1980 & 1990 & 1995 & 2000 & 2005 & 2010 & 2015 & 2020 \\
\hline \multirow[t]{3}{*}{ Capital Cost $(\$ / k W)$} & Flashed Steam & & & 1,444 & 1,372 & 1,250 & 1,194 & 1,147 & 1,100 \\
\hline & Binary & & & 2,112 & 1,994 & 1,875 & 1,754 & 1,696 & 1,637 \\
\hline & Hot Dry Rock & & & 5,519 & 5,176 & 4,756 & 4,312 & 3,794 & 3,276 \\
\hline \multirow[t]{3}{*}{ Fixed O\&M (\$/kW-yr) } & Flashed Steam & & & 96.4 & 87.1 & 74.8 & 66.3 & 62.25 & 58.2 \\
\hline & Binary & & & 87.4 & 78.5 & 66.8 & 59.5 & 55.95 & 52.4 \\
\hline & Hot Dry Rock & & & 219 & 207 & 191 & 179 & 171 & 163 \\
\hline
\end{tabular}




\section{Concentrating Solar Power}

\section{Technology Description}

Concentrating Solar Power (CSP) systems concentrate solar energy 50 to 10,000 times to produce hightemperature thermal energy, which is used to produce electricity for distributed or bulk generation process applications.

\section{System Concepts}

- In CSP systems, highly reflective suntracking mirrors produce temperatures of $400^{\circ} \mathrm{C}$ to $800^{\circ} \mathrm{C}$ in the working fluid of a receiver; this heat is used in conventional heat engines (steam or gas turbines or Stirling engines) to produce electricity at solar-toelectric efficiencies for the system of up to $30 \%$.

- CSP technologies provide firm, nonintermittent electricity generation (peaking or intermediate load capacity) when coupled with storage.

- Because solar-thermal technologies can yield extremely high temperatures, the technologies could some day be used for direct conversion (rather than indirect conversion through electrochemical reactions) of natural gas or water into hydrogen for future hydrogen-based economies. Representative Technologies

- A parabolic trough system focuses solar energy on a linear oil-filled receiver to collect heat to generate steam to power a steam turbine. When the sun is not shining, steam can be generated with a fossil fuel to meet utility needs. Some of the new trough plants include thermal storage. Plant sizes can range from 1.0 to $100 \mathrm{MW}_{\mathrm{e}}$

- A power tower system uses many large heliostats to focus the solar energy onto a tower-mounted central receiver filled with a molten-salt working fluid that produces steam. The hot salt can be stored extremely efficiently to allow power production to match utility demand, even when the sun is not shining. Plant size can range from 30 to $200 \mathrm{MW}_{\mathrm{e}}$.

- A dish/engine system uses a dish-shaped reflector to power a small Stirling or Brayton engine/generator or a high-concentrator PV module mounted at the focus of the dish. Dishes are 2-25 $\mathrm{kW}$ in size and can be used individually or in small groups for distributed, remote, or village power; or in clusters (1-10 $\mathrm{MW}_{\mathrm{e}}$ ) for utility-scale applications, including end-of-line support. They are easily hybridized with fossil fuel.

\section{Technology Applications}

- Nine parabolic trough plants, with a rated capacity of $354 \mathrm{MW}_{\mathrm{e}}$, have been operating in California since the 1980s. Trough system electricity costs of about $12 \phi-14 \phi / \mathrm{kWh}$ have been demonstrated commercially.

- Solar Two, a 10-MW e pilot power tower with three hours of storage, provided all the information needed to scale up to a 30-100 MW commercial plant, the first of which is now being planned in Spain. - A number of prototype dish/Stirling systems are currently operating in Nevada, Arizona, Colorado, and Spain. High levels of performance have been established; durability remains to be proven, although some systems have operated for more than 10,000 hours. 


\section{Current Status}

- New commercial plants are being considered for California, Nevada, New Mexico, Colorado, and Arizona. A 1MW power plant began operation in Arizona in 2005.

- The 10-MW Solar Two pilot power tower plant operated successfully near Barstow, California, leading to the first commercial plant being planned in Spain.

- Operations and maintenance costs have been reduced through technology improvements at the commercial parabolic trough plants in California by $40 \%$, saving plant operators $\$ 50$ million.

\section{Technology History}

Organized, large-scale development of solar collectors began in the United States in the mid-1970s under the Energy Research and Development Administration (ERDA) and continued with the establishment of the U.S. Department of Energy (DOE) in 1978.

\section{Troughs:}

- Parabolic trough collectors capable of generating temperatures greater than $500^{\circ} \mathrm{C}(932 \mathrm{~F})$ were initially developed for industrial process heat (IPH) applications. Acurex, SunTec, and Solar Kinetics were the key parabolic trough manufacturers in the United States during this period.

- Parabolic trough development also was taking place in Europe and culminated with the construction of the IEA Small Solar Power Systems (SSPS) Project/Distributed Collector System in Tabernas, Spain, in 1981. This facility consisted of two parabolic trough solar fields - one using a single-axis tracking Acurex collector and one the double-axis tracking parabolic trough collectors developed by M.A.N. of Munich, Germany.

- In 1982, Luz International Limited (Luz) developed a parabolic trough collector for IPH applications that was based largely on the experience that had been gained by DOE/Sandia and the SSPS projects.

- Southern California Edison (SCE) signed a power purchase agreement with Luz for the Solar Electric Generating System (SEGS) I and II plants, which came online in 1985. Luz later signed a number of Standard Offer (SO) power purchase contracts under the Public Utility Regulatory Policies Act (PURPA), leading to the development of the SEGS III through SEGS IX projects. Initially, the plants were limited by PURPA to $30 \mathrm{MW}$ in size; later this limit was raised to $80 \mathrm{MW}$. In 1991, Luz filed for bankruptcy when it was unable to secure construction financing for its 10th plant (SEGS X).

- The 354 MWe of SEGS trough systems are still being operated today. Experience gained through their operation will allow the next generation of trough technology to be installed and operated much more cost-effectively.

\section{Power Towers:}

- A number of experimental power tower systems and components have been field-tested around the world in the past 15 years, demonstrating the engineering feasibility and economic potential of the technology.

- Since the early 1980s, power towers have been fielded in Russia, Italy, Spain, Japan, and the United States.

- In early power towers, the thermal energy collected at the receiver was used to generate steam directly to drive a turbine generator.

- The U.S.-sponsored Solar Two was designed to demonstrate the dispatchability provided by molten-salt storage and to provide the experience necessary to lessen the perception of risk from these large systems.

- U.S. industry is currently pursuing a subsidized power tower project opportunity in Spain. This project, dubbed "Solar Tres," represents a 4x scale-up of the Solar 2 design.

\section{Dish/Engine Systems:}

- Dish/engine technology is the oldest of the solar technologies, dating back to the 1800 s when a number of companies demonstrated solar-powered steam Rankine and Stirling-based systems. 
- Development of modern technology began in the late 1970s and early 1980s. This technology used directly illuminated, tubular solar receivers, a kinematic Stirling engine developed for automotive applications, and silver/glass mirror dishes. Systems, nominally rated at $25 \mathrm{kWe}$, achieved solar-toelectric conversion efficiencies of around 30\%. Eight prototype systems were deployed and operated on a daily basis from 1986 through 1988.

- In the early 1990s, Cummins Engine Company attempted to commercialize dish/Stirling systems based on free-piston Stirling engine technology. Efforts included a 5 to $10 \mathrm{kWe}$ dish/Stirling system for remote power applications, and a $25 \mathrm{kWe}$ dish/engine system for utility applications. However, largely because of a corporate decision to focus on its core diesel-engine business, Cummins canceled their solar development in 1996. Technical difficulties with Cummins' free-piston Stirling engines were never resolved.

- Current dish/engine efforts are being continued by three U.S. industry teams - Science Applications International Corp. (SAIC) teamed with STM Corp., Boeing with Stirling Energy Systems, and WG Associates with Sunfire Corporation. SAIC and Boeing together have five $25 \mathrm{~kW}$ systems under test and evaluation at utility, industry, and university sites in Arizona, California, and Nevada. WGA has two 10kW systems under test in New Mexico, with a third off-grid system being developed in 2002 on an Indian reservation for water-pumping applications.

\section{Technology Future}

The levelized cost of electricity (in constant $2003 \$ / \mathrm{kWh}$ ) for three CSP configurations are projected at:

$\begin{array}{lcrrc} & \underline{2003} & \underline{2007} & \frac{2012}{2025} & \underline{2025} \\ \text { Trough } & 11.3 & 6.4 & 5.4 & \text { N/A } \\ \text { Power Tower } & 12.0 & 5.7 & 4.0 & \text { N/A } \\ \text { Dish/Engine } & 40.0 & 20.0 & \text { N/A } & 6\end{array}$

Source: Solar Energy Technologies Program Multiyear Technical Plan, NREL Report No. MP-52033875; DOE/GO-102004-1775.

- Parabolic troughs have been commercialized and nine plants (354 MW total) have operated in California since the 1980s.

- A 64-MW parabolic trough plant is under construction near Boulder City, Nevada. Nevada Power and Sierra Pacific Power will purchase the power to comply with the solar portion of Nevada's renewable portfolio standard.

- The World Bank's Solar Initiative is pursuing CSP technologies for less-developed countries. The World Bank considers CSP to be a primary candidate for Global Environment Facility funding. Market Context

- There is currently 350 MW of CSP generation in the United States, all of it in Southern California's Mojave Desert.

- Power purchase agreements have been signed for $800 \mathrm{MW}$ of new dish/engine capacity in California. The plants are anticipated to come on-line within the next several years. Significant domestic and international interest will likely result in additional projects.

- According to a recent study commissioned by the Department of Energy, CSP technologies can achieve significantly lower costs (below $6 \notin / \mathrm{kWh}$ ) at modest production volumes.

- At Congress' request, DOE scoped out what would be required to deploy 1,000MW of CSP in the Southwest United States. DOE is actively engaged with the Western Governors' Association to map a strategy to deploy 1-4 GW of CSP in the Southwest by 2015.

- A near-term to midterm opportunity exists to build production capacity in the United States for both domestic use and international exports.

Source: National Renewable Energy Laboratory. U.S. Climate Change Technology Program. Technology Options: For the Near and Long Term. DOE/PI-0002. November 2003 (draft update, September 2005). 


\section{Technology Performance}

\begin{tabular}{|c|c|c|c|c|c|c|c|}
\hline \multirow[t]{2}{*}{ Efficiency } & \multicolumn{7}{|c|}{$\begin{array}{l}\text { Source: Solar Energy Technologies Program Multiyear Technical Plan, NREL Report No. MP-520-33875; } \\
\text { DOE/GO-102004-1775. }\end{array}$} \\
\hline & & 2003 & 2005 & 2007 & 2012 & 2018 & 2025 \\
\hline \multirow[t]{3}{*}{ Capacity Factor (\%) } & Power Tower & 78 & 75 & 73 & NA & 72 & NA \\
\hline & Trough & 28 & 39 & 56 & 56 & NA & NA \\
\hline & Dish & 24 & NA & 24 & NA & NA & 50 \\
\hline \multirow[t]{3}{*}{ Solar to Electric Eff. (\%) } & Power Tower & 14 & 16 & 17 & NA & 18 & NA \\
\hline & Trough & 13 & 13 & 16 & 17 & NA & NA \\
\hline & Dish & 20 & NA & 23 & NA & NA & 26 \\
\hline Cost* & & 2003 & 2005 & 2007 & 2012 & 2018 & 2025 \\
\hline \multirow[t]{3}{*}{ Total (\$/kWe) } & Power Tower & 6800 & 4100 & 3500 & NA & 2500 & NA \\
\hline & Trough & 2805 & 3556 & 3422 & 2920 & NA & NA \\
\hline & Dish & NA & NA & NA & NA & NA & NA \\
\hline \multirow[t]{3}{*}{ O\&M (\$/kWh) } & Power Tower & .04 & .01 & .01 & NA & .01 & NA \\
\hline & Trough & .02 & .01 & .01 & .007 & NA & NA \\
\hline & Dish & NA & NA & NA & NA & NA & NA \\
\hline \multirow{3}{*}{$\begin{array}{l}\text { Levelized Cost of Energy } \\
(\$ / \mathrm{kWh})\end{array}$} & Power Tower & .12 & .06 & .06 & NA & .04 & NA \\
\hline & Trough & .11 & .10 & .06 & .05 & NA & NA \\
\hline & Dish & .40 & NA & .20 & NA & NA & .06 \\
\hline
\end{tabular}




\section{Photovoltaics}

\section{Technology Description}

Solar photovoltaic (PV) arrays use semiconductor devices called solar cells to convert sunlight to electricity without moving parts and without producing fuel wastes, air pollution, or greenhouse gases. Using solar PV for electricity - and eventually using solar PV to produce hydrogen for fuel cells for electric vehicles, by

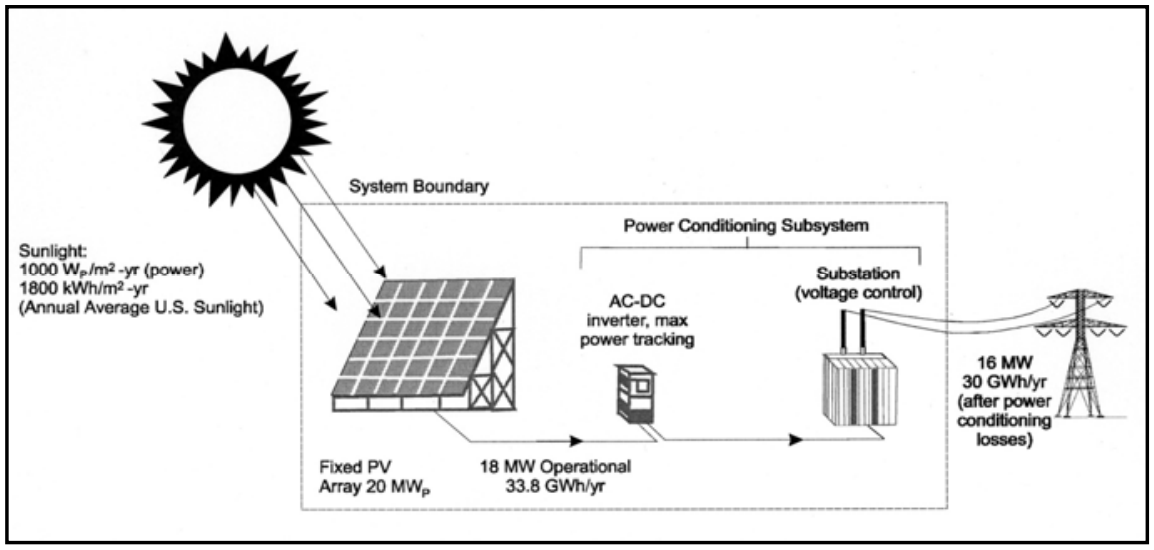
producing hydrogen from water - will help reduce carbon dioxide emissions worldwide.

\section{System Concepts}

- Flat-plate PV arrays use global sunlight; concentrators use direct sunlight. Modules are mounted on a stationary array or on single- or dual-axis sun trackers. Arrays can be ground-mounted or on all types of buildings and structures (e.g., semitransparent solar canopy). The DC output from PV can be conditioned into grid-quality AC electricity, or DC can be used to charge batteries or to split water to produce hydrogen (electrolysis of water).

- PV systems are expected to be used in the United States for residential and commercial buildings, peak-power shaving, and intermediate daytime load. With energy storage, PV can provide dispatchable electricity and/or produce hydrogen.

- Almost all locations in the United States and worldwide have enough sunlight for cost-effective PV. For example, U.S. sunlight in the contiguous states varies by only about $25 \%$ from an average in Kansas. Land area is not a problem for PV. Not only can PV be more easily sited in a distributed fashion than almost all alternatives (for example, on roofs or above parking lots), a PV-generating station $140 \mathrm{~km}$ by $140 \mathrm{~km}$ sited at a high solar insolation location in the United States (such as the desert Southwest) could generate all of the electricity needed in the country $\left(2.5 \times 10^{6} \mathrm{GWh} /\right.$ year, assuming a system efficiency of $10 \%$ and an area packing factor of $50 \%$ to avoid self-shading).

\section{Representative Technologies}

- Wafers of single-crystal or polycrystalline silicon - best cells: $25 \%$ efficiency; commercial modules: $12 \%-17 \%$. Silicon modules dominate the PV market and currently cost about $\$ 2 / \mathrm{W}_{\mathrm{p}}$ to manufacture.

- Thin-film semiconductors (e.g., amorphous silicon, copper indium diselenide, cadmium telluride, and dye-sensitized cells) - best cells: $12 \%-19 \%$; commercial modules: $6 \%-11 \%$. A new generation of thin-film PV modules is going through the high-risk transition to first-time and large-scale manufacturing. If successful, market share could increase rapidly.

- High-efficiency, single-crystal silicon and multijunction gallium-arsenide-alloy cells for concentrators - best cells: $27 \%$-39\% efficient; precommercial modules: $15 \%$-24\%; prototype systems are being tested in high solar areas in the southwest United States.

- Grid-connected PV systems currently sell for about $\$ 6-\$ 7 / \mathrm{W}_{\mathrm{p}}(17 \phi-22 \phi / \mathrm{kWh})$, including support structures, power conditioning, and land.

\section{Technology Applications}

- PV systems can be installed as either grid-supply technologies or as customer-sited alternatives to retail electricity. As suppliers of bulk grid power, PV modules would typically be installed in large array fields ranging in total peak output from a few megawatts on up. Very few of these systems have 
been installed to-date. A greater focus of the recent marketplace is on customer-sited systems, which may be installed to meet a variety of customer needs. These installations may be residential-size systems of just 1 kilowatt, or commercial-size systems of several hundred kilowatts. In either case, PV systems meet customer needs for alternatives to purchased power, reliable power, protection from price escalation, desire for green power, etc. Interest is growing in the use of PV systems as part of the building structure or façade ("building integrated"). Such systems use PV modules designed to look like shingles, windows, or other common building elements.

- PV systems are expected to be used in the United States for residential and commercial buildings; distributed utility systems for grid support, peak power shaving, and intermediate daytime load following; with electric storage and improved transmission for dispatchable electricity; and $\mathrm{H}_{2}$ production for portable fuel.

- Other applications for PV systems include electricity for remote locations, especially for billions of people worldwide who do not have electricity. Typically, these applications will be in hybrid minigrid or battery-charging configurations.

- Almost all locations in the United States and worldwide have enough sunlight for PV (e.g., U.S. sunlight varies by only about $25 \%$ from an average in Kansas).

- Land area is not a problem for PV. Not only can PV be more easily sited in a distributed fashion than almost all alternatives (e.g., on roofs or above parking lots), a PV-generating station $140 \mathrm{~km}$-by$140 \mathrm{~km}$ sited at an average solar location in the United States could generate all of the electricity needed in the country $\left(2.5 \times 10^{6} \mathrm{GWh} /\right.$ year $)$, assuming a system efficiency of $10 \%$ and an area packing factor of $50 \%$ (to avoid self-shading). This area ( $0.3 \%$ of U.S.) is less than one-third of the area used for military purposes in the United States.

\section{Current Status}

- Because of public/private partnerships, such as the Thin-Film Partnership with its national research teams, U.S. PV technology leads the world in measurable results such as record efficiencies for cells and modules. Another partnership, the PV Advanced Manufacturing R\&D program, has resulted in industry cost reductions of more than $60 \%$ and facilitated a sixteen-fold increase of manufacturing capacity during the past 12 years.

- A new generation of potentially lower-cost technologies (thin films) is entering the marketplace. A 30-megawatt amorphous silicon thin-film plant by United Solar reached full production in 2005. Two plants (First Solar and Shell Solar) using even newer thin films (cadmium telluride and copper indium diselenide alloys) are in first-time manufacturing at the MW-scale. Thin-film PV has been a focus of the federal R\&D efforts of the past decade, because it holds promise for module cost reductions.

- During the past two years, record sunlight-to-electricity conversion efficiencies for solar cells were set by federally funded universities, national labs, or industry in copper indium gallium diselenide (19\%-efficient cells and 13\%-efficient modules) and cadmium telluride (16\%-efficient cells and 11\%efficient modules). Cell and module efficiencies for these technologies have increased more than 50\% in the past decade.

- A unique multijunction (III-V materials alloy) cell was spun off to the space power industry, leading to a record cell efficiency (35\%) and an R\&D 100 Award in 2001. This device configuration is expected to dominate future space power for commercial and military satellites. Recent champion cell efficiency has reached 39\% under concentrated sunlight. DOE is interested in this technology (III-V multijunctions), as an insertion candidate for high efficiency terrestrial PV concentrator systems.

\section{Technology History}

- French physicist Edmond Becquerel first described the photovoltaic (PV) effect in 1839, but it remained a curiosity of science for the next three quarters of a century. At only 19, Becquerel found that certain materials would produce small amounts of electric current when exposed to light. The effect was first studied in solids, such as selenium, by Heinrich Hertz in the 1870s. Soon afterward, selenium PV cells were converting light to electricity at more than $1 \%$ efficiency. As a result, selenium was quickly adopted in the emerging field of photography for use in light-measuring devices. 
- Major steps toward commercializing PV were taken in the 1940s and early 1950s, when the Czochralski process was developed for producing highly pure crystalline silicon. In 1954, scientists at Bell Laboratories depended on the Czochralski process to develop the first crystalline silicon photovoltaic cell, which had an efficiency of $4 \%$. Although a few attempts were made in the 1950 s to use silicon cells in commercial products, it was the new space program that gave the technology its first major application. In 1958, the U.S. Vanguard space satellite carried a small array of PV cells to power its radio. The cells worked so well that PV technology has been part of the space program ever since.

- Even today, PV plays an important role in space, supplying nearly all power for satellites. The commercial integrated circuit technology also contributed to the development of PV cells. Transistors and PV cells are made from similar materials and operate on similar physical mechanisms. As a result, advances in transistor research provided a steady flow of new information about PV cell technology. (Today, however, this technology transfer process often works in reverse, as advances in PV research and development are sometimes adopted by the integrated circuit industry.)

- Despite these advances, PV devices in 1970 were still too expensive for most "down-to-Earth" uses. But, in the mid-1970s, increasing energy costs, sparked by a world oil crisis, renewed interest in making PV technology more affordable. Since then, the federal government, industry, and research organizations have invested billions of dollars in research, development, and production. A thriving industry now exists to meet the rapidly growing demand for photovoltaic products.

\section{Technology Future}

The levelized cost of electricity (in constant $2003 \$ / \mathrm{kWh}$ ) for PV are projected to be:

\begin{tabular}{|c|c|c|c|}
\hline & 2003 & 2007 & 2020 \\
\hline Itility-owned R & $0.25-0.40$ & 0.22 & $0.8-0.10$ \\
\hline
\end{tabular}

(crystalline $\mathrm{Si}$ )

Concentrator

$\begin{array}{llll}0.40 & 0.20 \quad \mathrm{NA} \quad 0.04-0.06\end{array}$

Source: Solar Energy Technologies Program Multiyear Technical Plan, NREL Report No. MP-52033875; DOE/GO-102004-1775.

- Worldwide, approximately 1,200 MW of PV were sold in 2004, with systems valued at more than $\$ 7$ billion; total installed PV is more than $2 \mathrm{GW}$. The U.S. world market share fell to about $12 \%$ in 2004.

- Worldwide, market growth for PV has averaged more than $20 \% /$ year for the past decade as a result of reduced prices and successful global marketing. Worldwide sales grew $36 \%$ in $2001,44 \%$ in 2002 , $33 \%$ in 2003 , and $60 \%$ in 2004 .

- Hundreds of applications are cost-effective for off-grid needs. However, the fastest-growing segment of the market is battery-free, grid-connected PV, such as roof-mounted arrays on homes and commercial buildings in the United States. California is subsidizing PV systems to reduce their dependence on natural gas, especially for peak daytime loads that match PV output, such as airconditioning.

\section{Market Context}

- Electricity for remote locations, especially for billions of people worldwide who do not have electricity.

- U.S. markets include retail electricity for residential and commercial buildings; distributed utility systems for grid support, peak-shaving, and other daytime uses (e.g., remote water pumping).

- Future electricity and hydrogen storage for dispatchable electricity, electric car-charging stations, and hydrogen production for portable fuel.

Source: National Renewable Energy Laboratory. U.S. Climate Change Technology Program. Technology Options: For the Near and Long Term. DOE/PI-0002. November 2003 (draft update, September 2005). 


\section{Photovoltaics}

\section{Market Data}

PV Cell/Module Production (Shipments)

Annual (MW)

U.S.

Japan

Europe

Rest of World

World Total

Cumulative (MW)

U.S.

Japan

Europe

Rest of World

World Total

U.S. \% of World Sales

Annual

Cumulative

\begin{tabular}{|c|c|c|c|c|c|c|c|c|c|c|c|}
\hline 1980 & 1985 & 1990 & 1995 & 1996 & 1997 & 1998 & 1999 & 2000 & 2001 & 2002 & 2003 \\
\hline 3 & 8 & 15 & 35 & 39 & 51 & 54 & 61 & 75 & 100 & 121 & 103 \\
\hline 1 & 10 & 17 & 16 & 21 & 35 & 49 & 80 & 129 & 171 & 251 & 364 \\
\hline 0 & 3 & 10 & 20 & 19 & 30 & 34 & 40 & 61 & 87 & 135 & 193 \\
\hline 0 & 1 & 5 & 6 & 10 & 9 & 19 & 21 & 23 & 33 & 54 & 84 \\
\hline 4 & 23 & 47 & 78 & 89 & 126 & 155 & 201 & 288 & 391 & 560 & 744 \\
\hline 1980 & 1985 & 1990 & 1995 & 1996 & 1997 & 1998 & 1999 & 2000 & 2001 & 2002 & 2003 \\
\hline 5 & 45 & 101 & 219 & 258 & 309 & 363 & 424 & 499 & 599 & 720 & 823 \\
\hline 1 & 26 & 95 & 185 & 206 & 241 & 290 & 370 & 499 & 670 & 921 & 1,285 \\
\hline 1 & 13 & 47 & 136 & 155 & 185 & 219 & 259 & 320 & 407 & 542 & 735 \\
\hline 0 & 3 & 20 & 45 & 55 & 65 & 83 & 104 & 127 & 160 & 214 & 298 \\
\hline 7 & 87 & 263 & 585 & 674 & 800 & 954 & 1,156 & 1,444 & 1,835 & 2,395 & 3,139 \\
\hline 1980 & 1985 & 1990 & 1995 & 1996 & 1997 & 1998 & 1999 & 2000 & 2001 & 2002 & 2003 \\
\hline $71 \%$ & $34 \%$ & $32 \%$ & $44 \%$ & $44 \%$ & $41 \%$ & $35 \%$ & $30 \%$ & $26 \%$ & $26 \%$ & $22 \%$ & $14 \%$ \\
\hline $75 \%$ & $52 \%$ & $39 \%$ & $37 \%$ & $38 \%$ & $39 \%$ & $38 \%$ & $37 \%$ & $35 \%$ & $33 \%$ & $30 \%$ & $26 \%$ \\
\hline
\end{tabular}

Annual Capacity

(Shipments retained

MW)*

Source: Strategies Unlimited

U.S.

Total World

$\begin{array}{ccccccccc}1980 & 1985 & 1990 & 1995 & 1996 & 1997 & 1998 & 1999 & 2000 \\ 1.4 & 4.2 & 5.1 & 8.4 & 9.2 & 10.5 & 13.6 & 18.4 & 21.3 \\ 3 & 15 & 39 & 68 & 79 & 110 & 131 & 170 & 246\end{array}$

*Excludes indoor consumer (watches/calculators). 
Cumulative Capacity

(Shipments retained, $\mathrm{MW})^{*}$

U.S.

Total World
Source: Strategies Unlimited

$\begin{array}{rrrrrrrrr}1980 & 1985 & 1990 & 1995 & 1996 & 1997 & 1998 & 1999 & 2000 \\ 3 & 23 & 43 & 76 & 85 & 96 & 109 & 128 & 149 \\ 6 & 61 & 199 & 474 & 552 & 663 & 794 & 964 & 1,210\end{array}$

*Excludes indoor consumer (watches/calculators).

U.S. Shipments (MW)

Annual Shipments

Total

Imports

Exports

Domestic Total On-Grid*

Domestic Total Off-Grid*

Cumulative Shipments

(since 1982)

Total

Imports

Exports

Domestic Total On-Grid*

Domestic Total Off-Grid*

Source: EIA, Annual Energy Review 2004, DOE/EIA-0384(2004) (Washington, D.C., September 2004), Tables 10.5 and 10.6; and EIA, Renewable Energy Annual 2003, DOE/EIA-0603(2003) (Washington, D.C., December 2004) Table 26.

\begin{tabular}{rrrrrrrrrrrr}
1985 & 1990 & 1995 & \multicolumn{1}{c}{1996} & 1997 & 1998 & 1999 & $\mathbf{2 0 0 0}$ & $\mathbf{2 0 0 1}$ & $\mathbf{2 0 0 2}$ & $\mathbf{2 0 0 3}$ & $\mathbf{2 0 0 4}$ \\
5.8 & 13.8 & 31.1 & 35.5 & 46.4 & 50.6 & 76.8 & 88.2 & 97.7 & 112.1 & 109.4 & 181.1 \\
0.3 & 1.4 & 1.3 & 1.9 & 1.9 & 1.9 & 4.8 & 8.8 & 10.2 & 7.3 & 9.7 & 47.7 \\
1.7 & 7.5 & 19.9 & 22.4 & 33.8 & 35.5 & 55.6 & 68.4 & 61.4 & 66.8 & 60.7 & 102.8 \\
& & & & & & & & & & & \\
0.4 & 0.2 & 1.7 & 1.8 & 2.2 & 4.2 & 6.9 & 4.9 & 10.1 & 13.7 & 18.9 & 55.9 \\
3.7 & 6.1 & 9.5 & 11.2 & 10.3 & 10.8 & 14.4 & 15.0 & 26.2 & 31.6 & 29.8 & 22.4 \\
& & & & & & & & & & & \\
1985 & 1990 & 1995 & 1996 & 1997 & 1998 & 1999 & $\mathbf{2 0 0 0}$ & $\mathbf{2 0 0 1}$ & $\mathbf{2 0 0 2}$ & $\mathbf{2 0 0 3}$ & $\mathbf{2 0 0 4}$ \\
& & & & & & & & & & & \\
35.2 & 84.7 & 193.3 & 228.8 & 275.2 & 325.7 & 402.5 & 490.7 & 588.4 & 700.5 & 809.8 & 991.0 \\
1.0 & 5.6 & 14.3 & 16.2 & 18 & 19.9 & 24.7 & 33.5 & 43.7 & 51.0 & 60.8 & 108.5 \\
5.7 & 32.9 & 104 & 126.5 & 160.3 & 195.8 & 251.3 & 319.7 & 381.0 & 447.8 & 508.5 & 611.3 \\
2.9 & 4.7 & 8.2 & 10.0 & 12.2 & 16.5 & 23.3 & 28.2 & 38.3 & 52.0 & 70.9 & 126.9 \\
26.6 & 47.2 & 81.1 & 92.3 & 102.7 & 113.5 & 127.9 & 142.8 & 169.0 & 200.6 & 230.4 & 252.8
\end{tabular}

Domestic Totals include imports and exclude exports. Electricity generation only, excludes water pumping, communications

transportation, consumer goods, health, and original equipment manufacturers.

U.S. Shipments (MW)

Source: Renewable Energy World, July-August 2003, Volume 6, Number 4; and PV News, Vol. 23, No. 5, May 2004

Total

Imports

Exports

198019851990

$\begin{array}{cccc}1995 & 1996 & 1997 & 1998 \\ 34.8 & 38.9 & 51.0 & 53.7 \\ 24.0 & 25.1 & 36.3 & 37.9\end{array}$

19992000

60.8

2.0

39.8
75.0

4.0

55.0
20012002

100.3

5.0

73.3 \begin{tabular}{ll}
103.0 \\
\hline
\end{tabular}

$9.0 \quad 18.0$

$81.2 \quad 54.0$ 


\begin{tabular}{|c|c|c|c|c|c|c|c|c|c|c|c|c|}
\hline \multirow[t]{2}{*}{$\begin{array}{l}\text { Annual U.S. Installations } \\
\text { (MW) }\end{array}$} & \multicolumn{12}{|c|}{$\begin{array}{l}\text { Source: The } 2002 \text { National Survey Report of Photovoltaic Power Applications in the United States, prepared } \\
\text { by Paul D. Maycock and Ward Bower, May 31, 2003, prepared for the IEA, Table 1. http://www.oja- } \\
\text { services.nl/iea-pvps/nsr02/download/usa.pdf; and PV News, Vol. } 23 \text { No. } 5 \text {. }\end{array}$} \\
\hline & 1980 & 1985 & 1990 & 1995 & 1996 & 1997 & 1998 & 1999 & 2000 & 2001 & 2002 & 2003 \\
\hline $\begin{array}{l}\text { Grid-Connected } \\
\text { Distributed }\end{array}$ & & & & 1.5 & 2.0 & 2.0 & 2.2 & 3.7 & 5.5 & 12.0 & 22.0 & 32.0 \\
\hline Off-Grid Consumer & & & & 3.5 & 4.0 & 4.2 & 4.5 & 5.5 & 6.0 & 7.0 & 8.4 & 9.0 \\
\hline Government & & & & 0.8 & 1.2 & 1.5 & 1.5 & 2.5 & 2.5 & 1.0 & 1.0 & 1.0 \\
\hline $\begin{array}{l}\text { Off-Grid } \\
\text { Industrial/Commercial }\end{array}$ & & & & 4.0 & 4.4 & 4.8 & 5.2 & 6.5 & 7.5 & 9.0 & 13.0 & 16.0 \\
\hline Consumer (<40 w) & & & & 2.0 & 2.2 & 2.2 & 2.4 & 2.5 & 2.5 & 3.0 & 4.0 & 4.0 \\
\hline Central Station & & & & 0 & 0 & 0 & 0 & 0 & 0 & 0 & 0 & 5.0 \\
\hline Total & & & & 11.8 & 13.8 & 14.7 & 15.8 & 20.7 & 24.0 & 32.0 & 48.4 & 67.0 \\
\hline
\end{tabular}

\begin{tabular}{|c|c|c|c|c|c|c|c|c|c|c|c|}
\hline \multirow[t]{2}{*}{$\begin{array}{l}\text { Cumulative U.S. } \\
\text { Installations* (MW) }\end{array}$} & \multicolumn{11}{|c|}{$\begin{array}{l}\text { Source: The } 2002 \text { National Survey Report of Photovoltaic Power Applications in the United States, prepared } \\
\text { by Paul D. Maycock and Ward Bower, May 31, 2003, prepared for the IEA, Table } 1 \\
\text { http://www.oia-services.nl/iea-pvps/nsro2/usa2.htm. }\end{array}$} \\
\hline & 1980 & 1990 & 1995 & 1996 & 1997 & 1998 & 1999 & 2000 & 2001 & 2002 & 2003 \\
\hline Off-grid Residential & & & 19.3 & 23.3 & 27.5 & 32.0 & 37.5 & 43.5 & 50.5 & & \\
\hline Off-grid Nonresidential & & & 25.8 & 30.2 & 35.0 & 40.2 & 46.7 & 55.2 & 64.7 & & \\
\hline On-grid Distributed & & & 9.7 & 11.0 & 13.7 & 15.9 & 21.1 & 28.1 & 40.6 & & \\
\hline On-grid Centralized & & & 12.0 & 12.0 & 12.0 & 12.0 & 12.0 & 12.0 & 12.0 & & \\
\hline Total & & & 66.8 & 76.5 & 88.2 & 100.1 & 117.3 & 138.8 & 167.8 & & \\
\hline
\end{tabular}

${ }^{*}$ Excludes installations less than $40 \mathrm{~kW}$.

\begin{tabular}{|c|c|c|c|c|c|c|c|c|c|c|c|}
\hline \multirow{2}{*}{$\begin{array}{l}\text { Annual World Installations } \\
\text { (MW) }\end{array}$} & \multicolumn{11}{|c|}{ Source: Renewable Energy World, July-August 2003, Volume 6, Number 4.} \\
\hline & 1980 & 1985 & 1990 & 1995 & 1996 & 1997 & 1998 & 1999 & 2000 & 2001 & 2002 \\
\hline Consumer Products & & & 16 & & 22 & 26 & 30 & 35 & 40 & 45 & 60 \\
\hline U.S. Off-Grid Residential & & & 3 & & 8 & 9 & 10 & 13 & 15 & 19 & 25 \\
\hline World Off-Grid Rural & & & 6 & & 15 & 19 & 24 & 31 & 38 & 45 & 60 \\
\hline Communications/ Signal & $\mathrm{N} / \mathrm{A}$ & $N / A$ & 14 & $\mathrm{~N} / \mathrm{A}$ & 23 & 28 & 31 & 35 & 40 & 46 & 60 \\
\hline PV/Diesel, Commercial & & & 7 & & 12 & 16 & 20 & 25 & 30 & 36 & 45 \\
\hline Grid-Conn. Res., Comm. & & & 1 & & 7 & 27 & 36 & 60 & 120 & 199 & 270 \\
\hline Central Station (>100kW) & & & 1 & & 2 & 2 & 2 & & 5 & 5 & 5 \\
\hline Total & & & 48 & & 89 & 127 & 153 & 201 & 288 & 395 & 525 \\
\hline
\end{tabular}




\begin{tabular}{|c|c|c|c|c|c|c|c|c|c|c|c|}
\hline \multirow[t]{2}{*}{$\begin{array}{l}\text { Annual U.S. Shipments by } \\
\text { Cell Type (MW) }\end{array}$} & \multicolumn{11}{|c|}{$\begin{array}{l}\text { Source: PV News, Vol. 15, No. 2, Feb. 1996; Vol. 16, No. 2, Feb. 1997; Vol. 17, No. 2, Feb. 1998; Vol. 18, } \\
\text { No. 2, Feb. 1999; Vol. 19, No. 3, March 2000; Vol. 20, No. 3, March 2001; Vol. 21, No. 3, March 2002; Vol. } \\
\text { 22, No. 5, May 2003; and Renewable Energy World, July-August 2003, Volume 6, Number } 4 .\end{array}$} \\
\hline & 1980 & 1985 & 1990 & 1995 & 1996 & 1997 & 1998 & 1999 & 2000 & 2001 & 2002 \\
\hline Single Crystal & & & & 22.0 & 24.1 & 31.8 & 30.0 & 36.6 & 44.0 & 63.0 & 71.9 \\
\hline $\begin{array}{l}\text { Flat-Plate Polycrystal (other } \\
\text { ribbon) }\end{array}$ & than & & & 9.0 & 10.3 & 14.0 & 14.7 & 16.0 & 17.0 & 20.6 & 24 \\
\hline Amorphous Silicon & & & & 1.3 & 1.1 & 2.5 & 3.8 & 5.3 & 6.5 & 7.3 & 11 \\
\hline $\begin{array}{l}\text { Crystal Silicon } \\
\text { Concentrators }\end{array}$ & & & & 0.3 & 0.7 & 0.7 & 0.2 & 0.5 & 0.5 & 0.5 & 0.5 \\
\hline Ribbon Silicon & $\mathrm{N} / \mathrm{A}$ & $N / A$ & $\mathrm{~N} / \mathrm{A}$ & 2.0 & 3.0 & 4.0 & 4.0 & 4.2 & 5.0 & 6.9 & 6.9 \\
\hline Cadmium Telluride & & & & 0.1 & 0.4 & 0 & 0 & 0 & 0 & 0.6 & 1.6 \\
\hline Microcrystal SI/Single SI & & & & & & & & & & & - \\
\hline SI on Low-Cost-Sub & & & & 0.1 & 0.3 & 0.5 & 1.0 & 2.0 & 2.0 & 1.7 & 1.7 \\
\hline A-SI on Cz Slice & & & & & & & & & 0 & 0 & - \\
\hline Total & & & & 34.8 & 39.9 & 53.5 & 53.7 & 64.6 & 75 & 100.6 & 120.6 \\
\hline
\end{tabular}

\begin{tabular}{|c|c|c|c|c|c|c|c|c|c|c|c|}
\hline \multirow[t]{2}{*}{$\begin{array}{l}\text { Annual World Shipments } \\
\text { by Cell Type (MW) }\end{array}$} & \multicolumn{11}{|c|}{$\begin{array}{l}\text { Source: PV News, Vol. 15, No. 2, Feb. 1996; Vol. 16, No. 2, Feb. 1997; Vol. 17, No. 2, Feb. 1998; Vol. 18, } \\
\text { No. 2, Feb. 1999; Vol. 19, No. 3, March 2000; Vol. 20, No. 3, March 2001; Vol. 21, No. 3, March 2002; Vol. } \\
\text { 22, No. 5, May 2003; and Renewable Energy World, July-August 2003, Volume 6, Number } 4 .\end{array}$} \\
\hline & 1980 & 1985 & 1990 & 1995 & 1996 & 1997 & 19980 & 1999 & 2000 & 2001 & 2002 \\
\hline Single Crystal & & & & 46.7 & 48.5 & 62.8 & 59.8 & 73 & 89.7 & 150.41 & 162.31 \\
\hline Flat-Plate Polycrystal & & & & 20.1 & 24 & 43 & 66.3 & 88.4 & 140.6 & 278.9 & 306.55 \\
\hline Amorphous Silicon & & & & 9.1 & 11.7 & 15 & 19.2 & 23.9 & 27 & 28.01 & 32.51 \\
\hline $\begin{array}{l}\text { Crystal Silicon } \\
\text { Concentrators }\end{array}$ & & & & 0.3 & 0.7 & 0.2 & 0.2 & 0.5 & 0.5 & 0.5 & 0.5 \\
\hline Ribbon Silicon & N/A & N/A & $\mathrm{N} / \mathrm{A}$ & 2 & 3 & 4 & 4 & 4.2 & 14.7 & 16.9 & 16.9 \\
\hline Cadmium Telluride & & & & 1.3 & 1.6 & 1.2 & 1.2 & 1.2 & 1.2 & 2.1 & 4.6 \\
\hline Microcrystal SI/Single SI & & & & & & & & & & & 3.7 \\
\hline SI on Low-Cost-Sub & & & & 0.1 & 0.3 & 0.5 & 1 & 2 & 2 & 1.7 & 1.7 \\
\hline A-SI on Cz Slice & & & & & & & & 8.1 & 12 & 30 & 30 \\
\hline Total & & & & 79.5 & 89.8 & 126.7 & 151.7 & 201.3 & 287.7 & 512.22 & 561.77 \\
\hline
\end{tabular}




\begin{tabular}{|c|c|c|c|c|c|c|c|c|c|c|c|c|}
\hline \multirow[t]{2}{*}{$\begin{array}{l}\text { Annual U.S. Shipments by } \\
\text { Cell Type (MW) }\end{array}$} & \multicolumn{12}{|c|}{$\begin{array}{l}\text { Source: EIA, Solar Collector Manufacturing Activity annual reports, 1982-1992; and EIA, Renewable Energy } \\
\text { Annual 1997, Table 27; REA 2000, Table 26; REA 2002, Table 28; REA 2003, Table } 28 .\end{array}$} \\
\hline & 1985 & 1990 & 1995 & 1996 & 1997 & 1998 & 1999 & 2000 & 2001 & 2002 & 2003 & 2004 \\
\hline Single-Crystal Silicon & & & 19.9 & 21.7 & 30 & 30.8 & 47.2 & 51.9 & 54.7 & 74.7 & 59.4 & 94.9 \\
\hline $\begin{array}{l}\text { Cast and Ribbon } \\
\text { Crvstalline Silicon }\end{array}$ & & & 9.9 & 12.3 & 14.3 & 16.4 & 26.2 & 33.2 & 29.9 & 29.4 & 38.6 & 64.2 \\
\hline Crystalline Silicon Total & 5.5 & 12.5 & 29.8 & 34 & 44.3 & 47.2 & 73.5 & 85.2 & 84.7 & 104.1 & 98.0 & 159.1 \\
\hline Thin-Film Silicon & 0.3 & 1.3 & 1.3 & 1.4 & 1.9 & 3.3 & 3.3 & 2.7 & 12.5 & 7.4 & 11.0 & 22.0 \\
\hline $\begin{array}{l}\text { Concentrator Silicon } \\
\text { Other }\end{array}$ & & & 0.1 & 0.2 & 0.2 & 0.1 & 0.1 & 0.3 & 0.5 & 0.6 & 0.5 & 0 \\
\hline Total & 5.8 & 13.8 & 31.2 & 35.6 & 46.3 & 50.6 & 76.8 & 88.2 & 97.7 & 112.1 & 109.5 & 181.1 \\
\hline
\end{tabular}

\begin{tabular}{|c|c|c|c|c|c|c|c|c|c|}
\hline \multirow[t]{2}{*}{$\begin{array}{l}\text { Annual Grid-Connected } \\
\text { Capacity (MW) }\end{array}$} & \multicolumn{9}{|c|}{$\begin{array}{l}\text { Source: The } 2002 \text { National Survey Report of Photovoltaic Power Applications in the United States, prepared } \\
\text { by Paul D. Maycock and Ward Bower, May 31, 2003, prepared for the IEA, derived from Table } 1 \\
\text { http://www.oja-services.nl/iea-pvps/nsr02/usa2.htm. Japan data from PV News, Vol. 23, No. 1, January } \\
2004 \text {. }\end{array}$} \\
\hline & 1995 & 1996 & 1997 & 1998 & 1999 & 2000 & 2001 & 2002 & 2003 \\
\hline U.S. & & 1.3 & 2.7 & 2.2 & 5.2 & 7.0 & 12.5 & & \\
\hline Japan & 3.9 & 7.5 & 19.5 & 24.1 & 57.7 & 74.4 & 91.0 & 155.0 & 168.0 \\
\hline
\end{tabular}

Note: Japan data not necessarily grid-connected

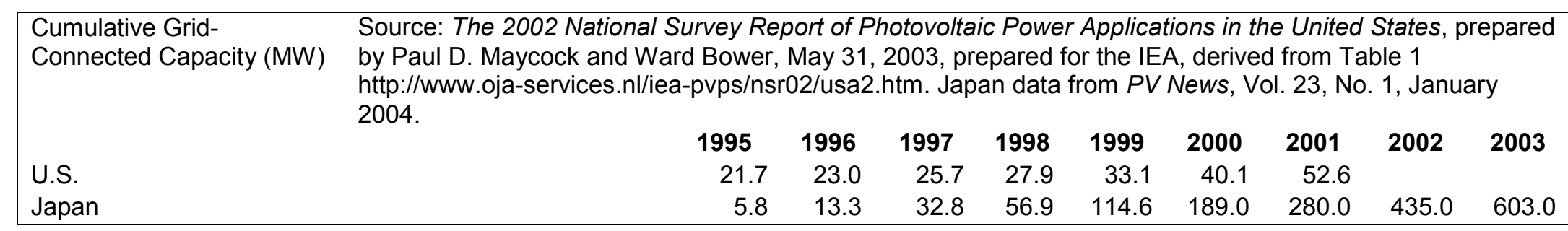

\begin{tabular}{|c|c|c|c|c|c|c|c|c|}
\hline \multirow[t]{2}{*}{$\begin{array}{l}\text { Japan Grid-Connected } \\
\text { Capacity (MW) }\end{array}$} & \multicolumn{8}{|c|}{$\begin{array}{l}\text { Source: IEA Photovoltaic Power Systems Program, National Survey Report of PV Power Applications in } \\
\text { Japan 2002, http://www.oja-services.nl/iea-pvps/nsr02/jpn2.htm Table } 1 .\end{array}$} \\
\hline & 1995 & 1996 & 1997 & 1998 & 1999 & 2000 & 2001 & 2002 \\
\hline Annual & 6.0 & 9.7 & 22.6 & 34.7 & 71.3 & 114.8 & 119.3 & 178.2 \\
\hline Cumulative & 13.7 & 23.4 & 46.0 & 80.7 & 151.9 & 266.7 & 386.0 & 564.2 \\
\hline
\end{tabular}




\begin{tabular}{|c|c|c|c|c|c|c|c|c|c|c|c|c|}
\hline Annual U.S.-Installed Capacity (MW) & Source: $F$ & enewab & Electr & Plant & formati & n Syste & (REPiS, & Version & $7, N R E$ & 2003. & & \\
\hline Top 10 States & 1980 & 1985 & 1990 & 1995 & 1996 & 1997 & 1998 & 1999 & 2000 & 2001 & 2002 & 2003 \\
\hline California & & 0.034 & 0.016 & 0.720 & 0.900 & 0.606 & 0.577 & 2.993 & 5.833 & 7.236 & 16.072 & 7.452 \\
\hline Arizona & & 0.004 & & 0.026 & 0.067 & 0.724 & 0.301 & 0.574 & 0.177 & 2.516 & 1.333 & 0.008 \\
\hline New York & & & 0.013 & 0.067 & 0.425 & 0.021 & 0.246 & 0.041 & 0.377 & & 1.078 & \\
\hline Ohio & & & & & & 0.001 & 0.001 & 0.010 & 0.144 & 0.004 & 1.986 & \\
\hline Hawaii & & & & 0.000 & 0.046 & 0.008 & 0.291 & 0.113 & 0.250 & 0.275 & & \\
\hline Texas & 0.006 & 0.015 & 0.002 & 0.008 & & 0.010 & 0.133 & 0.248 & 0.089 & 0.028 & 0.020 & \\
\hline Colorado & & & & 0.018 & 0.100 & 0.006 & 0.132 & 0.344 & 0.137 & & & \\
\hline Georgia & & & & & 0.352 & & & 0.019 & 0.221 & & 0.003 & 0.032 \\
\hline Florida & 0.009 & & 0.008 & 0.018 & & 0.036 & 0.047 & 0.106 & 0.202 & 0.031 & 0.050 & \\
\hline Illinois & & & & & & 0.002 & 0.005 & 0.034 & 0.043 & 0.449 & 0.044 & \\
\hline Total U.S. & 0.015 & 0.078 & 0.049 & 1.029 & 2.131 & 1.670 & 1.899 & 5.140 & 8.244 & 10.807 & 21.251 & 8.008 \\
\hline
\end{tabular}

2003 data not complete as REPiS database is updated through 2002.

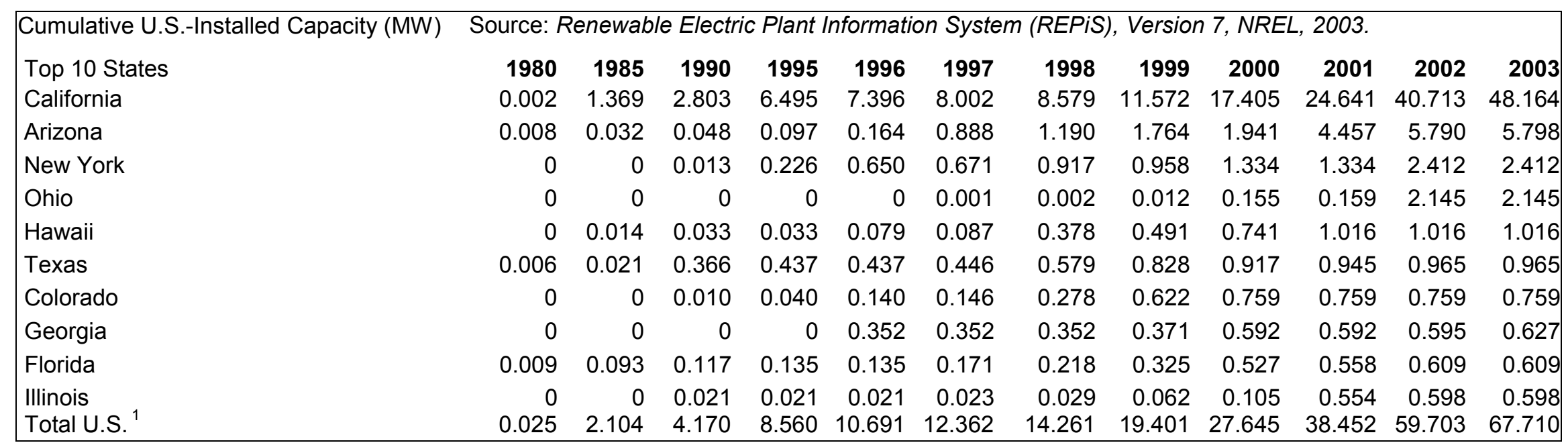

${ }^{1}$ There are an additional 3.4 MW of photovoltaic capacity that are not accounted for here because they have no specific online date. 2003 data not complete as REPiS database is updated through 2002. 


\section{Technology Performance}

\begin{tabular}{|c|c|c|c|c|c|}
\hline \multirow[b]{2}{*}{ Efficiency } & \multicolumn{5}{|c|}{$\begin{array}{l}\text { Source: Solar Energy Technologies Program Multiyear Technical Plan, NREL Report No. MP-520-33875; } \\
\text { DOE/GO-102004-1775. }\end{array}$} \\
\hline & & 2003 & 2007 & 2020 & 2025 \\
\hline \multirow[t]{2}{*}{ Cell (\%) } & Crystalline Silicon & NA & NA & NA & NA \\
\hline & Concentrator & 25 & 33 & NA & 40 \\
\hline \multirow[t]{2}{*}{ Module (\%) } & Crystalline Silicon & 14 & 15 & $15-20$ & NA \\
\hline & Concentrator & NA & NA & NA & NA \\
\hline \multirow[t]{2}{*}{ System (\%) } & Crystalline Silicon & 11.5 & 14 & 16 & NA \\
\hline & Concentrator & 15 & 22 & NA & 33 \\
\hline Cost & & 2003 & 2007 & 2020 & 2025 \\
\hline \multirow{2}{*}{ Module $\left(\begin{array}{l}\left.\$ W_{2}\right) \\
2\end{array}\right.$} & Crystalline Silicon & 4.80 & 2.50 & $1.00-1.50$ & NA \\
\hline & \multicolumn{5}{|c|}{$(\$ / \mathrm{m}$} \\
\hline \multirow[t]{2}{*}{ BOS (\$/Wp) } & Crystalline Silicon & 0.85 & 0.60 & 0.40 & NA \\
\hline & Concentrator & 0.60 & 0.30 & NA & 0.15 \\
\hline \multirow[t]{2}{*}{ Total Installed System $(\$ / W p)$} & Crystalline Silicon * & $6.20-9.50$ & 5.20 & $2.30-2.80$ & NA \\
\hline & Concentrator & NA & NA & NA & NA \\
\hline \multirow[t]{2}{*}{ O\&M (\$/kWh) } & Crystalline Silicon & 0.08 & .0 .02 & 0.005 & NA \\
\hline & Concentrator & 0.02 & 0.01 & NA & 0.005 \\
\hline
\end{tabular}




\section{Wind Energy}

\section{Technology Description}

Wind turbine technology converts the kinetic energy in wind to electricity. Grid-connected wind power reduces greenhouse gas emissions by displacing the need for natural gas and coal-fired generation. Village and off-grid applications are important for displacing diesel generation and for improving quality of life, especially in developing countries.

\section{System Concepts}

- Most modern wind turbines operate using aerodynamic lift generated by airfoil-type blades, yielding much higher efficiency than traditional windmills that relied on wind "pushing" the blades. Lifting forces spin the blades, driving a generator that produces electric power in proportion to wind speed. Turbines either rotate at constant speed and directly link to the grid, or at variable speed for better performance, using a power electronics system for grid connection. Utility-scale turbines for wind plants range in size up to several megawatts, and smaller turbines (under 100 kilowatts) serve a range of distributed, remote, and standalone power applications.

\section{Representative Technologies}

- The most common machine configuration is a three-bladed wind turbine, which operates "upwind" of the tower, with the blades facing into the wind. To improve the cost-effectiveness of wind turbines, technology advances are being made for rotors and controls, drive trains, towers, manufacturing methods, site-tailored designs, and offshore and onshore foundations.

\section{Technology Applications}

- In the United States, the wind energy capacity exploded from 1,600 MW in 1994 to more than $9,200 \mathrm{MW}$ by the end of 2005 - enough to serve more than 2.5 million households.

- Current performance is characterized by levelized costs of $3 \phi-5 \phi / \mathrm{kWh}$ (depending on resource quality and financing terms), capacity factors of 30\%-50\%, availability of $95-98 \%$, total installed costs of approximately $\$ 1,000-\$ 1,300 / \mathrm{kW}$, and efficiencies of $65 \%-75 \%$ of theoretical (Betz limit) maximum.

\section{Current Status}

- In 1989 , the wind program set a goal of $5 \notin / \mathrm{kWh}$ by 1995 and $4 \notin / \mathrm{kWh}$ by 2000 for sites with average wind speeds of $16 \mathrm{mph}$. The program and the wind industry met the goals as part of dramatic cost reductions from $25 \phi-50 \phi / \mathrm{kWh}$ in the early $1980 \mathrm{~s}$ to $4 \phi-6 \phi / \mathrm{kWh}$ today (2005).

- Wind power is the world's fastest-growing energy source. In the past decade, the global wind energy capacity has increased tenfold from 3,500 MW in 1994 to almost 50,000 MW by the end of 2004. During 2004, nearly 8,000 MW of new capacity was added worldwide.

- Domestic public interest in environmentally responsible electric generation technology is reflected by new state energy policies and in the success of "green marketing" of wind power throughout the country.

- The National Wind Technology Center (operated by the National Renewable Energy Laboratory in Golden, Colorado) is recognized as a world-class center for wind energy R\&D and has many facilities - such as blade structural test stands and a large gearbox test stand - not otherwise available to the domestic industry.

\section{Technology History}

- Prior to 1980, DOE sponsored (and NASA managed) large-scale turbine development - starting with hundred-kilowatt machines and culminating in the late 1980s with the 3.2-MW, DOE-supported Mod-5 machine built by Boeing.

- Small-scale (2-20 kW) turbine development efforts also were supported by DOE at the Rocky Flats test site. Numerous designs were available commercially for residential and farm uses. 
- In 1981, the first wind farms were installed in California by a small group of entrepreneurial companies. PURPA provided substantial regulatory support for this initial surge.

- During the next five years, the market boomed, installing U.S., Danish, and Dutch turbines.

- By 1985, annual market growth had peaked at $400 \mathrm{MW}$. Following that, federal tax credits were abruptly ended, and California incentives weakened the following year.

- In 1988, European market exceeded the United States for the first time, spurred by ambitious national programs. A number of new companies emerged in the U.K. and Germany.

- In 1989, DOE's focus changed to supporting industry-driven research on components and systems. At the same time, many U.S. companies became proficient in operating the 1,600 MW of installed capacity in California. They launched into value engineering and incremental increases in turbine size.

- DOE program supported value-engineering efforts and other advanced turbine-development efforts.

- In 1992, Congress passed the Renewable Energy Production Tax Credit (REPI), which provided a 1.5 cent $/ \mathrm{kWh}$ tax credit for wind-produced electricity. Coupled with several state programs and mandates, installations in the United States began to increase.

- In 1997, Enron purchased Zond Energy Systems, one of the value-engineered turbine manufacturers. In 2002, General Electric Co. purchased Enron Wind Corporation.

- In FY2001, DOE initiated a low wind-speed turbine development program to broaden the U.S. cost-competitive resource base.

- In 2004, Clipper Windpower began testing on its highly innovative, multiple-drive 2.5 MW Liberty prototype wind turbine.

- In 2005, the U.S. wind energy industry had a record-breaking year for new installations, adding more than 2,400 MW of new capacity to the nation's electric grid.

- In 2006, the U.S. Department of Energy signed a \$27 million contract with General Electric to develop a multimegawatt offshore wind power system; and Clipper Windpower begins manufacturing its multiple-drive, 2.5 MW turbine.

\section{Technology Future}

The levelized cost of electricity (2002 $\$ / \mathrm{MWh}$ ) for wind energy technology is projected to be:

\begin{tabular}{|c|c|c|c|c|c|c|}
\hline & 2005 & 2010 & 2020 & 2030 & 2040 & 2000 \\
\hline Class 4 & 5.5 & 4.0 & 3.1 & 2.9 & 2.9 & 2.8 \\
\hline Class 6 & 4.1 & 3.0 & 2.6 & 2.5 & 2.4 & \\
\hline
\end{tabular}

Source: Projected Benefits of Federal Energy Efficiency and Renewable Energy Programs - FY 2006 Budget Request, NREL/TP-620-37931, May 2005.

- Installed wind capacity in the United States expanded from 2,554 MW to 4,150 MW during the period of 2000 to 2005 , but still make up less than $1 \%$ of total U.S. generation.

- California has the greatest installed wind capacity, followed by Texas, Iowa, Minnesota, Oregon, Washington, Wyoming, New Mexico, Colorado, and Oklahoma.

- Wind technology is competitive today in bulk power markets at Class 5 and 6 wind sites, with support from the production tax credit - and in high-value niche applications or markets that recognize non-cost attributes. Its competitiveness is negatively affected by policies regarding ancillary services and transmission and distribution regulations.

- Continued cost reductions from low wind-speed technologies will increase the resource areas available for wind development by 20 -fold and move wind generation five times closer to major load centers.

- Wind energy is often the least variable cost source of generation in grid supplied electricity and due to its less predictable (variable resource) supply; wind usually displaces natural gas and coal generated electricity as these sources adjust to hourly changes in demand and supply. Emerging markets for wind energy include providing energy for water purification, irrigation, and hydrogen production. 
- Utility restructuring is a critical challenge to increased deployment in the near term because it emphasizes short-term, low-capital-cost alternatives - and lacks public policy to support deployment of sustainable technologies such as wind energy, leaving wind power at a disadvantage.

- In the United States, the wind industry is thinly capitalized, except for General Electric Wind Energy, which recently acquired wind technology and manufacturing assets in April 2002. About six manufacturers and six to 10 developers characterize the U.S. industry.

- In Europe, there are about 10 turbine manufacturers and about 20 to 30 project developers.

European manufacturers have established North American manufacturing facilities and are actively participating in the U.S. market.

- Initial lower levels of wind deployment (up to $15 \%-20 \%$ of the total U.S. electric system capacity) are not expected to introduce significant grid reliability issues. Because the wind resource is variable, intensive use of this technology at larger penetrations may require modification to system operations or ancillary services. Transmission infrastructure upgrades and expansion will be required for large penetrations of onshore wind turbines. However, offshore resources are located close to major load centers.

- Small wind turbines (100 kW and smaller) for distributed and residential grid-connected applications are being used to harness the nation's abundant wind resources and defer impacts to the long-distance transmission market. Key market drivers include state renewable portfolio standards, incentive programs, and demand for community-owned wind applications.

Source: National Renewable Energy Laboratory. U.S. Climate Change Technology Program. Technology Options: For the Near and Long Term. DOE/PI-0002. November 2003 (draft update, September 2005). 


\section{Wind}

\section{Market Data}

\begin{tabular}{|c|c|c|c|c|c|c|c|c|c|c|c|c|}
\hline $\begin{array}{l}\text { Grid-Connected Wind } \\
\text { Capacity (MW) }\end{array}$ & \multicolumn{12}{|c|}{$\begin{array}{l}\text { Source: Reference IEA (data supplemented by Windpower Monthly, April 2001), } 2001 \text { data from Windpower Monthly, } \\
\text { January 2002, } 2002 \text { data from AWEA "Global Wind Energy Market Report 2004". }\end{array}$} \\
\hline Cumulative & 1980 & 1985 & 1990 & 1995 & 1996 & 1997 & 1998 & 1999 & 2000 & 2001 & 2002 & 2003 \\
\hline U.S. & 10 & 1,039 & 1,525 & 1,770 & 1,794 & 1,741 & 1,890 & 2,455 & 2,554 & 4,240 & 4,685 & 6,374 \\
\hline Germany & 2 & 3 & 60 & 1,137 & 1,576 & 2,082 & 2,874 & 4,445 & 6,095 & 8,100 & 11,994 & 14,609 \\
\hline Spain & 0 & 0 & 9 & 126 & 216 & 421 & 834 & 1,539 & 2,334 & 3,175 & 4,825 & 6,202 \\
\hline Denmark & 3 & 50 & 310 & 630 & 785 & 1,100 & 1,400 & 1,752 & 2,338 & 2,417 & 2,889 & 3,110 \\
\hline Netherlands & 0 & 0 & 49 & 255 & 305 & 325 & 364 & 416 & 447 & 483 & 693 & 912 \\
\hline Italy & & & 3 & 22 & 70 & 103 & 180 & 282 & 427 & 682 & 788 & 904 \\
\hline & 0 & 0 & 6 & 193 & 264 & 324 & 331 & 344 & 391 & 477 & 552 & 649 \\
\hline Uléturope & 5 & 58 & 450 & 2,494 & 3,384 & 4,644 & 6,420 & 9,399 & 12,961 & 16,362 & 23,308 & 28,706 \\
\hline India & 0 & 0 & 20 & 550 & 820 & 933 & 968 & 1,095 & 1,220 & 1,426 & 1,702 & 2110 \\
\hline Japan & 0 & 0 & 1 & 10 & 14 & 7 & 32 & 75 & 121 & 250 & 415 & 686 \\
\hline Rest of World & 0 & 0 & 6 & 63 & 106 & 254 & 315 & 574 & 797 & 992 & 1,270 & 1,418 \\
\hline World Total & 15 & 1,097 & 2,002 & 4,887 & 6,118 & 7,579 & 9,625 & 13,598 & 17,653 & 23,270 & 31,128 & 39,294 \\
\hline
\end{tabular}

\begin{tabular}{|c|c|c|c|c|c|c|c|c|c|c|c|c|}
\hline \multirow{2}{*}{$\begin{array}{l}\text { Installed U.S. Wind Capacity } \\
\text { (MW) }\end{array}$} & \multicolumn{12}{|c|}{ Source: Renewable Electric Plant Information System (REPiS), Version 7, NREL, 2003.} \\
\hline & 1980 & 1985 & 1990 & 1995 & 1996 & 1997 & 1998 & 1999 & 2000 & 2001 & 2002 & $2003^{2}$ \\
\hline Annual & 0.023 & 337 & 154 & 37 & 8 & 8 & 173 & 695 & 124 & 1,843 & 454 & 12 \\
\hline Cumulative $^{1}$ & 0.060 & 674 & 1,569 & 1,773 & 1,781 & 1,788 & 1,961 & 2,656 & 2,780 & 4,623 & 5,078 & 5,090 \\
\hline
\end{tabular}

${ }^{1}$ There are an additional $48 \mathrm{MW}$ of wind capacity that are not accounted for here because they have no specific online date.

${ }^{2} 2003$ data not complete as REPiS database is updated through 2002.

\begin{tabular}{|c|c|c|c|c|c|c|c|c|c|}
\hline \multirow[t]{2}{*}{ Annual Market Shares } & \multicolumn{9}{|c|}{$\begin{array}{l}\text { Source: US DOE- 1982-87 wind turbine shipment database; 1988-94. DOE Wind Program Data Sheets; } \\
\text { 1996-2000 American Wind Energy Association }\end{array}$} \\
\hline & 1980 & 1985 & 1990 & 1995 & 1996 & 1997 & 1998 & 1999 & 2000 \\
\hline U.S. Mfg Share of U.S. Market & $98 \%$ & $44 \%$ & $36 \%$ & $67 \%$ & NA & $38 \%$ & $78 \%$ & $44 \%$ & $0 \%$ \\
\hline U.S. Mfg Share of World Market & $65 \%$ & $42 \%$ & $20 \%$ & $5 \%$ & $2 \%$ & $4 \%$ & $13 \%$ & $9 \%$ & $6 \%$ \\
\hline
\end{tabular}




\begin{tabular}{|c|c|c|c|c|c|c|c|c|c|c|c|c|c|c|}
\hline \multirow{2}{*}{\multicolumn{3}{|c|}{$\begin{array}{l}\text { State-Installed Capacity } \\
\text { Annual State-Installed Capacity (MW) }\end{array}$}} & \multicolumn{11}{|c|}{ Source: American Wind Energy Association and Global Energy Concepts. } & \multirow[b]{3}{*}{2005} \\
\hline & & & & & & & & & & & & & & \\
\hline Top 10 States & & & 1990 & 1995 & 1996 & 1997 & 1998 & 1999 & 2000 & 2001 & 2002 & 2003 & 2004 & \\
\hline California* & & N/A & N/A & 3.0 & 0.0 & 8.4 & 0.7 & 250.0 & 0.0 & 67.1 & 108.0 & 206.3 & 99.7 & 61.9 \\
\hline Texas & & 0 & 0 & 41.0 & 0.0 & 0.0 & 0.0 & 139.2 & 0.0 & 915.2 & 0.0 & 203.5 & 0.0 & 701.8 \\
\hline Minnesota & & 0 & 0 & 0.0 & 0.0 & 0.2 & 109.2 & 137.6 & 17.8 & 28.6 & 17.9 & 239.8 & 52.1 & 145.3 \\
\hline lowa & & 0 & 0 & 0.1 & 0.0 & 1.2 & 3.1 & 237.5 & 0.0 & 81.8 & 98.5 & 49.2 & 310.7 & 202.3 \\
\hline Wyoming & & 0 & 0 & 0.0 & 0.1 & 0.0 & 1.2 & 71.3 & 18.1 & 50.0 & 0.0 & 144.0 & 0.0 & 3.8 \\
\hline Oregon & & 0 & 0 & 0.0 & 0.0 & 0.0 & 25.1 & 0.0 & 0.0 & 131.8 & 64.8 & 41.0 & 0.0 & 75.0 \\
\hline Washington & & 0 & 0 & 0.0 & 0.0 & 0.0 & 0.0 & 0.0 & 0.0 & 176.9 & 48.0 & 15.6 & 0.0 & 149.4 \\
\hline Colorado & & 0 & 0 & 0.0 & 0.0 & 0.0 & 0.0 & 21.6 & 0.0 & 39.6 & 0.0 & 16 & 6.0 & 0.1 \\
\hline New Mexico & & 0 & 0 & 0.0 & 0.0 & 0.0 & 0.0 & 1.3 & 0.0 & 0.0 & 0.0 & 3 & 60.0 & 140.0 \\
\hline Oklah & & 0 & 0 & 0.0 & 0.0 & 0.0 & 0.0 & 0.0 & 0.0 & 0.0 & 0.0 & 176.3 & 0.0 & 298.3 \\
\hline Total of 10 States & & N/A & N/A & 44.1 & 0.1 & 9.8 & 139.3 & 858.5 & 35.9 & 1491.0 & 337.2 & 1443.0 & 528.5 & $1,777.8$ \\
\hline Total U.S. & & N/A & $\mathrm{N} / \mathrm{A}$ & 44.0 & 1.0 & 16.0 & 142.0 & 884.0 & 67.0 & 1694.0 & 449.7 & 1694.5 & 559.9 & $2,431.4$ \\
\hline Top 10 States & 1980 & 1985 & 1990 & 1995 & 1996 & 1997 & 1998 & 1999 & 2000 & 2001 & 2002 & 2003 & 2004 & 2005 \\
\hline California* & & N/A & N/A & $1,387.0$ & $1,387.0$ & $1,396.0$ & $1,396.0$ & $1,646.0$ & $1,646.0$ & $1,714.0$ & $1,822.0$ & $2,042.6$ & $2,142.3$ & $2,204.2$ \\
\hline Texas & & 0 & 0 & 41.0 & 41.0 & 41.0 & 41.0 & 180.2 & 180.2 & $1,095.5$ & $1,095.5$ & $1,293.0$ & $1,293.0$ & $1,994.8$ \\
\hline Minnesota & & 0 & 0 & 25.7 & 25.7 & 25.9 & 135.1 & 272.7 & 290.5 & 319.1 & 335.9 & 562.7 & 614.8 & 760.1 \\
\hline lowa & & 0 & 0 & 0.7 & 0.8 & 2.0 & 5.0 & 242.5 & 242.5 & 324.2 & 422.7 & 471.2 & 781.9 & 984.2 \\
\hline Wyoming & & 0 & 0 & 0.0 & 0.1 & 0.1 & 1.3 & 72.5 & 90.6 & 140.6 & 140.6 & 284.6 & 284.6 & 288.4 \\
\hline Oregon & & 0 & 0 & 0.0 & 0.0 & 0.0 & 25.1 & 25.1 & 25.1 & 157.5 & 218.4 & 259.4 & 259.4 & 334.4 \\
\hline Washington & & 0 & 0 & 0.0 & 0.0 & 0.0 & 0.0 & 0.0 & 0.0 & 178.2 & 228.2 & 243.8 & 243.8 & 393.2 \\
\hline Colorado & & 0 & 0 & 0.0 & 0.0 & 0.0 & 0.0 & 21.6 & 21.6 & 61.2 & 61.2 & 223.2 & 229.2 & 229.3 \\
\hline New Mexico & & 0 & 0 & 0.0 & 0.0 & 0.0 & 0.0 & 1.3 & 1.3 & 1.3 & 1.3 & 206.6 & 266.6 & 406.6 \\
\hline Oklahoma & & & 0 & 0.0 & 0.0 & 0.0 & 0.0 & 0.0 & 0.0 & 0.0 & 0.0 & 176.3 & 176.3 & 474.6 \\
\hline Total of 10 states & & $\mathrm{N} / \mathrm{A}$ & $\mathrm{N} / \mathrm{A}$ & $1,454.4$ & $1,454.6$ & $1,465.0$ & $1,603.5$ & $2,461.9$ & $2,497.8$ & $3,991.6$ & $4,325.8$ & $5,763.4$ & $6,291.9$ & $8,069.7$ \\
\hline Total U.S. & 10.0 & 1039.0 & 1525.0 & $1,697.0$ & $1,698.0$ & $1,706.0$ & $1,848.0$ & $2,511.0$ & $2,578.0$ & $4,275.0$ & $4,686.0$ & $6,353.0$ & $6,912.9$ & $9,344.3$ \\
\hline
\end{tabular}




\begin{tabular}{|c|c|c|c|c|c|c|c|c|c|c|c|c|c|}
\hline \multirow[t]{2}{*}{$\begin{array}{l}\text { Cumulative Installed } \\
\text { Capacity (MW) }\end{array}$} & \multicolumn{13}{|c|}{$\begin{array}{l}\text { Source: U.S. - EIA, Annual Energy Review 2004, DOE/EIA-0384(2004) (Washington, D.C., August 2005), Table 8.11a; } \\
\text { IEA R\&D Wind Countries - IEA Wind Energy Annual Reports, 1995-2003. IEA Total - "Renewables Information 2002," } \\
\text { IEA, } 2002 .\end{array}$} \\
\hline & 1980 & 1985 & 1990 & 1995 & 1996 & 1997 & 1998 & 1999 & 2000 & 2001 & $2002^{1}$ & 2003 & 2004 \\
\hline \multirow{3}{*}{$\begin{array}{l}\text { U.S. } \\
\text { IEA R\&D Wind Countries }{ }^{2} \\
\text { IEA Total }\end{array}$} & & 17.5 & 1,799 & 1,731 & 1,678 & 1,610 & 1,720 & 2,252 & 2,377 & 3,864 & 4,417 & 5,995 & 6,190 \\
\hline & & & & & & & & 10,040 & 15,440 & 21,553 & 27,935 & 35,275 & \\
\hline & $\mathrm{N} / \mathrm{A}$ & & 2,386 & 4,235 & 5,124 & 6,228 & 8,001 & 11,390 & 16,103 & & & & \\
\hline
\end{tabular}

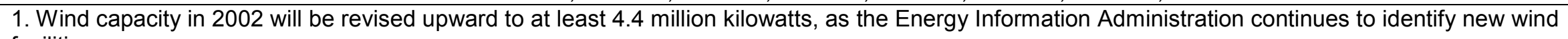
facilities.

2. Data for IEA R\&D Wind Countries through 2001 included 16 IEA countries. Ireland and Switzerland were added in 2002 and Portugal was added in 2003.

\begin{tabular}{|c|c|c|c|c|c|c|c|c|c|c|c|c|c|}
\hline \multirow[t]{2}{*}{$\begin{array}{l}\text { Annual Generation from } \\
\text { Cumulative Installed } \\
\text { Capacity (Billion kWh) }\end{array}$} & \multicolumn{13}{|c|}{$\begin{array}{l}\text { Source: U.S. - EIA, Annual Energy Review 2004, DOE/EIA-0384(2004) (Washington, D.C., August 2005),Table 8.2a; } \\
\text { IEA R\&D Wind Countries - IEA Wind Energy Annual Reports, 1995-2003. IEA Total - "Renewables Information 2002", } \\
\text { IEA, 2002. }\end{array}$} \\
\hline & 1980 & 1985 & 1990 & 1995 & 1996 & 1997 & 1998 & 1999 & 2000 & 2001 & 2002 & 2003 & 2004 \\
\hline U.S. & $N / A$ & 0.006 & 2.8 & 3.2 & 3.2 & 3.3 & 3.0 & 4.5 & 5.6 & 6.7 & 10.4 & 11.2 & 14.2 \\
\hline IEA R\&D Wind Countries ${ }^{2}$ & & & & 7.1 & 8.4 & 10.9 & 11.3 & 22.0 & 26.4 & 37.2 & 49.0 & 69.0 & \\
\hline IEA Total & & & 3.8 & 7.3 & 8.4 & 10.7 & 14.4 & 19.1 & 28.9 & & & & \\
\hline
\end{tabular}

2. Data for International Energy Agency R\&D Wind Countries through 2001 included 16 IEA countries. Ireland and Switzerland were added in 2002 and Portugal was added in 2003.

\begin{tabular}{|c|c|c|c|c|c|c|c|c|c|c|c|c|c|}
\hline \multirow{2}{*}{$\begin{array}{l}\text { Annual Wind Energy } \\
\text { Consumption for Electric } \\
\text { Generation (Trillion Btu) }\end{array}$} & \multicolumn{13}{|c|}{ Source: EIA, Annual Energy Review 2004, DOE/EIA-0384(2003) (Washington, D.C., September 2004), Table 8.4a } \\
\hline & 1980 & 1985 & 1990 & 1995 & 1996 & 1997 & 1998 & 1999 & 2000 & 2001 & 2002 & 2003 & 2004 \\
\hline $\begin{array}{l}\text { U.S. Total } \\
\text { (s)=Less than } 0.5 \text { trillion } \\
\text { Btu. }\end{array}$ & $\mathrm{N} / \mathrm{A}$ & (s) & 29.0 & 32.6 & 33.4 & 33.6 & 30.9 & 45.9 & 57.1 & 68.4 & 104.8 & 114.6 & 143.0 \\
\hline
\end{tabular}




\section{Technology Performance}

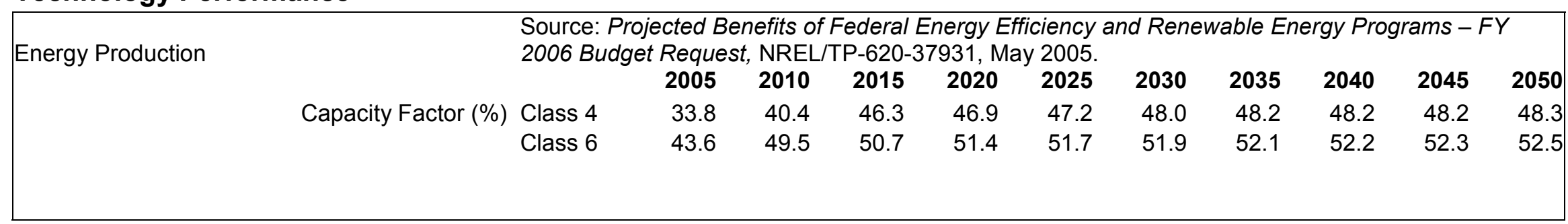

\begin{tabular}{|c|c|c|c|c|c|c|c|c|c|c|c|c|}
\hline \multirow{2}{*}{$\begin{array}{l}\text { Cost } \\
\text { (2002 dollars) }\end{array}$} & & \multicolumn{11}{|c|}{$\begin{array}{l}\text { Source: Projected Benefits of Federal Energy Efficiency and Renewable Energy Programs - FY } \\
2006 \text { Budget Request, NREL/TP-620-37931, May } 2005 .\end{array}$} \\
\hline & & & 2005 & 2010 & 2015 & 2020 & 2025 & 2030 & 2035 & 2040 & 2045 & 2050 \\
\hline & \multirow[t]{2}{*}{ Capital Cost $(\$ / k W)$} & Class 4 & 1103 & 982 & 919 & 893 & 866 & 866 & 861 & 856 & 851 & 840 \\
\hline & & Class 6 & $105 c$ & 893 & 840 & 819 & 814 & 788 & 777 & 767 & 756 & 746 \\
\hline & O\&M (\$/kW) & Onshore & 25.0 & 20.0 & 16.0 & 15.0 & 14.2 & 13.8 & 13.5 & 13.2 & 12.8 & 12.8 \\
\hline \multicolumn{2}{|c|}{ Levelized Cost of Energy* $(\$ / k W h)$} & \multicolumn{11}{|c|}{$\begin{array}{l}\text { Source: Projected Benefits of Federal Energy Efficiency and Renewable Energy Programs - FY } \\
2006 \text { Budget Request, NREL/TP-620-37931, May } 2005 .\end{array}$} \\
\hline \multirow[t]{3}{*}{ (2002 dollars) } & & & 2005 & 2010 & 2015 & 2020 & 2025 & 2030 & 2035 & 2040 & 2045 & 2050 \\
\hline & & Class 4 & 55.1 & 40.3 & 32.3 & 30.8 & 29.6 & 29.0 & 28.7 & 28.5 & 28.2 & 27.8 \\
\hline & & Class 6 & $40 . c$ & 30.3 & 27.2 & 26.1 & 25.6 & 24.7 & 24.3 & 23.8 & 23.4 & 23.1 \\
\hline
\end{tabular}




\section{Hydrogen}

\section{Technology Description}

Similar to electricity, hydrogen can be produced from many sources, including fossil fuels, renewable resources, and nuclear energy. Hydrogen and electricity can be converted from one to the other using electrolyzers (electricity to hydrogen) and fuel cells (hydrogen to electricity). Hydrogen is a clean energy storage medium, particularly for distributed generation. When hydrogen produced from renewable resources is used in fuel cell vehicles or power devices, there are very few emissions - the major byproduct is water. With improved conventional energy conversion and carbon-capture technologies, hydrogen from fossil resources can be used efficiently with few emissions.

The Hydrogen Economy vision is based on this cycle: separate water into hydrogen and oxygen using renewable or nuclear energy, or fossil resources with carbon sequestration. Use

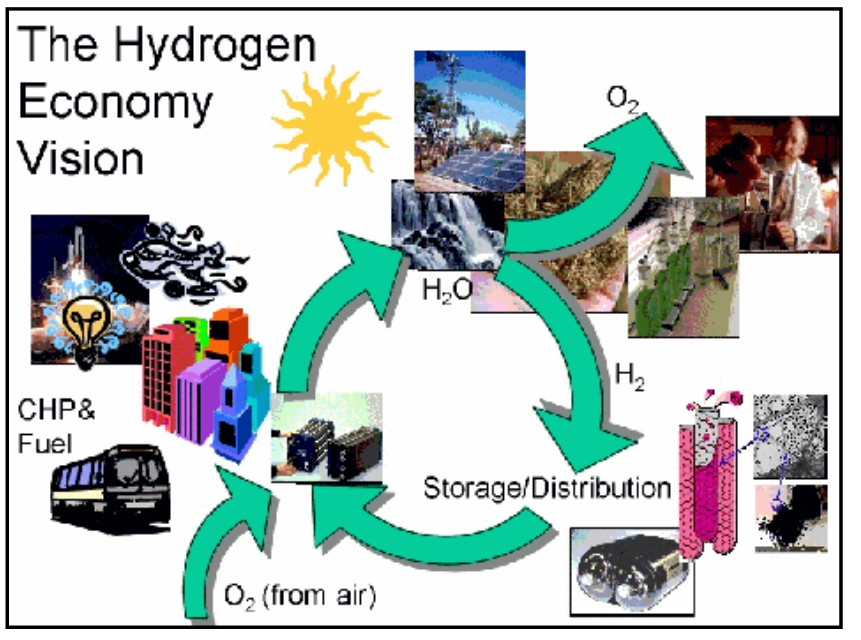
the hydrogen to power a fuel cell, internal combustion engine, or turbine, where hydrogen and oxygen (from air) recombine to produce electrical energy, heat, and water to complete the cycle. This process produces no particulate matter, no carbon dioxide, and no pollution.

\section{System Concepts}

- Hydrogen can be used as a sustainable transportation fuel or stored to meet peak-power demand. It also can be used as a feedstock in chemical processes.

- Hydrogen produced by decarbonization of fossil fuels followed by sequestration of the carbon can enable the continued, clean use of fossil fuels during the transition to a carbon-free Hydrogen Economy.

- A hydrogen system is comprised of production, storage, distribution, and use.

- A fuel cell works like a battery but does not run down or need recharging. It will produce electricity and heat as long as fuel (hydrogen) is supplied. A fuel cell consists of two electrodes - a negative electrode (or anode) and a positive electrode (or cathode) - sandwiched around an electrolyte.

Hydrogen is fed to the anode, and oxygen is fed to the cathode. Activated by a catalyst, hydrogen atoms separate into protons and electrons, which take different paths to the cathode. The electrons go through an external circuit, creating a flow of electricity. The protons migrate through the electrolyte to the cathode, where they reunite with oxygen and the electrons to produce water and heat. Fuel cells can be used to power vehicles, or to provide electricity and heat to buildings.

\section{Representative Technologies} Hydrogen production

- Thermochemical conversion of fossil fuels, biomass, and wastes to produce hydrogen and $\mathrm{CO}_{2}$ with the $\mathrm{CO}_{2}$ available for sequestration (large-scale steam methane reforming is widely commercialized)

- Renewable (wind, solar, geothermal, hydro) and nuclear electricity converted to hydrogen by electrolysis of water (commercially available electrolyzers supply a small but important part of the super-high-purity hydrogen market)

- Photoelectrochemical and photobiological processes for direct production of hydrogen from sunlight and water.

Hydrogen storage

- Pressurized gas and cryogenic liquid (commercial today) 
- Higher pressure (10,000 psi), carbon-wrapped conformable gas cylinders

- Cryogenic gas

- Chemically bound as metal or chemical hydrides or physically adsorbed on carbon nanostructures Hydrogen distribution

- By pipeline (relatively significant pipeline networks exist in industrial areas of the Gulf Coast region, and near Chicago)

- By decentralized or point-of-use production using natural gas or electricity

- By truck (liquid and compressed hydrogen delivery is practiced commercially)

Hydrogen use

- Transportation sector: internal combustion engines or fuel cells to power vehicles with electric power trains. Potential long-term use as an aviation fuel and in marine applications

- Industrial sector: ammonia production, reductant in metal production, hydrotreating of crude oils, hydrogenation of oils in the food industry, reducing agent in electronics industry.

- Buildings sector: combined heat, power, and fuel applications using fuel cells

- Power sector: fuel cells, gas turbines, generators for distributed power generation

\section{Technology Applications}

- In the United States, nearly all of the hydrogen used as a chemical (i.e. for petroleum refining and upgrading, ammonia production) is produced from natural gas. The current main use of hydrogen as a fuel is by NASA to propel rockets.

- Hydrogen's potential use in fuel and energy applications includes powering vehicles, running turbines or fuel cells to produce electricity, and generating heat and electricity for buildings. The current focus is on hydrogen's use in fuel cells.

The primary fuel cell technologies under development are:

Phosphoric acid fuel cell (PAFC) - A phosphoric acid fuel cell (PAFC) consists of an anode and a cathode made of a finely dispersed platinum catalyst on carbon paper, and a silicon carbide matrix that holds the phosphoric acid electrolyte. This is the most commercially developed type of fuel cell and is being used in hotels, hospitals, and office buildings. More than 250 commercial units exist in 19 countries on five continents. This fuel cell also can be used in large vehicles, such as buses.

Polymer electrolyte membrane (PEM) fuel cell - The polymer electrolyte membrane (PEM) fuel cell uses a fluorocarbon ion exchange with a polymeric membrane as the electrolyte. The PEM cell appears to be more adaptable to automobile use than the PAFC type of cell. These cells operate at relatively low temperatures and can vary their output to meet shifting power demands. These cells are the best candidates for light-duty vehicles, for buildings, and much smaller applications.

Solid oxide fuel cells (SOFC) - Solid oxide fuel cells (SOFC) currently under development use a thin layer of zirconium oxide as a solid ceramic electrolyte, and include a lanthanum manganate cathode and a nickel-zirconia anode. This is a promising option for high-powered applications, such as industrial uses or central electricity generating stations.

Direct-methanol fuel cell (DMFC) - A relatively new member of the fuel cell family, the directmethanol fuel cell (DMFC) is similar to the PEM cell in that it uses a polymer membrane as an electrolyte. However, a catalyst on the DMFC anode draws hydrogen from liquid methanol, eliminating the need for a fuel reformer.

Molten carbonate fuel cell (MCFC) - The molten carbonate fuel cell uses a molten carbonate salt as the electrolyte. It has the potential to be fueled with coal-derived fuel gases or natural gas.

Alkaline fuel cell - The alkaline fuel cell uses an alkaline electrolyte such as potassium hydroxide. Originally used by NASA on missions, it is now finding applications in hydrogen-powered vehicles. Regenerative or Reversible Fuel Cells - This special class of fuel cells produces electricity from hydrogen and oxygen, but can be reversed and powered with electricity to produce hydrogen and oxygen. 


\section{Current Status}

- Currently, $48 \%$ of the worldwide production of hydrogen is via large-scale steam reforming of natural gas. Today, we safely use about 90 billion cubic meters ( 3.2 trillion cubic feet) of hydrogen yearly.

- Hydrogen technologies are in various stages of development across the system:

Production - Hydrogen production from conventional fossil-fuel feedstocks is commercial, and results in significant $\mathrm{CO}_{2}$ emissions. Large-scale $\mathrm{CO}_{2}$ sequestration options have not been proved and require R\&D. Current commercial electrolyzer systems are 55-75\% efficient, but the cost of hydrogen is strongly dependent on the cost of electricity. Production processes using wastes and biomass are under development, with a number of engineering scale-up projects underway. Direct conversion of sunlight to hydrogen using a semiconductor-based photoelectrochemical cell was recently demonstrated at $12.4 \%$ efficiency.

Storage - Liquid and compressed gas tanks are available and have been demonstrated in a small number of bus and automobile demonstration projects. Lightweight, fiber-wrapped tanks have been developed and tested for higher-pressure hydrogen storage. Experimental metal hydride tanks have been used in automobile demonstrations. Alternative solid-state storage systems using alanates and carbon nanotubes are under development.

Use - Small demonstrations by domestic and foreign bus and energy companies have been undertaken. Small-scale power systems using fuel cells fuel cells have been introduced to the power generation market, but subsidies are required to be economically competitive. Small fuel cells for battery replacement applications have been developed. The United States is conducting a major five-year learning demonstration of fuel cell vehicles and hydrogen infrastructure. Four teams comprised of automobile manufacturers and energy companies are conducting the study.

- Major industrial companies are pursuing $R \& D$ in fuel cells and hydrogen production technologies with a mid-term time frame for deployment for both stationary and vehicular applications.

\section{Technology History}

- From the early 1800 s to the mid-1900s, a gaseous product called town gas (manufactured from coal) supplied lighting and heating for America and Europe. Town gas is 50\% hydrogen, with the rest comprised of mostly methane and carbon dioxide, with $3 \%$ to $6 \%$ carbon monoxide. Then, large natural gas fields were discovered, and networks of natural gas pipelines displaced town gas. (Town gas is still found in limited use today in Europe and Asia.)

- From 1958 to present, the National Aeronautics and Space Administration (NASA) has continued work on using hydrogen as a rocket fuel and electricity source via fuel cells. NASA became the worldwide largest user of liquid hydrogen and is renowned for its safe handling of hydrogen.

- During the 20th century, hydrogen was used extensively as a key component in the manufacture of ammonia, methanol, gasoline, and heating oil. It was - and still is - also used to make fertilizers, glass, refined metals, vitamins, cosmetics, semiconductor circuits, soaps, lubricants, cleaners, margarine, and peanut butter.

- Recently, (in the late 20th century/dawn of 21 st century) many industries worldwide have begun producing hydrogen, hydrogen-powered vehicles, hydrogen fuel cells, and other hydrogen products. From Japan's hydrogen delivery trucks to BMW's liquid-hydrogen passenger cars; to Ballard's fuel cell transit buses in Chicago and Vancouver, B.C.; to Palm Desert's Renewable Transportation Project; to Iceland's commitment to be the first hydrogen economy by 2030; to the forward-thinking work of many hydrogen organizations worldwide; to Hydrogen Now!'s public education work; the dynamic progress in Germany, Europe, Japan, Canada, the United States, Australia, Iceland, and several other countries launch hydrogen onto the main stage of the world's energy scene. Specific U.S.-based examples of hydrogen production and uses are as follows:

- A fully functional integrated renewable hydrogen utility system for the generation of hydrogen using concentrated solar power was demonstrated by cooperative project between industry and an Arizona utility company. 
- A renewable energy fuel cell system in Reno, Nevada, produced hydrogen via electrolysis using intermittent renewable resources such as wind and solar energy.

- An industry-led project has developed fueling systems for small fleets and home refueling of passenger vehicles. The refueling systems deliver gaseous hydrogen up to 5,000 psi to the vehicle. A transit agency in California installed an autothermal reformer, generating hydrogen for buses and other vehicles. This facility also operates a PV-powered electrolysis system to provide renewable hydrogen to their fleet.

\section{Technology Future}

- Fuel cells are a promising technology for use as a source of heat and electricity for buildings, and as an electrical power source for electric vehicles. Although these applications would ideally run off pure hydrogen, in the near-term they are likely to be fueled with natural gas, methanol, or even gasoline. Reforming these fuels to create hydrogen will allow the use of much of our current energy infrastructure - gas stations, natural gas pipelines - while fuel cells are phased in. The electricity grid and the natural gas pipeline system will serve to supply primary energy to hydrogen producers. - By 2010, advances will be made in photobiological and photoelectrochemical processes for hydrogen production, efficiencies of fuel cells for electric power generation will increase, and advances will be made in fuel cell systems based on carbon structures, alanates, and metal hydrides. The RD\&D target for 2010 is $\$ 45 / \mathrm{kW}$ for internal combustion engines operating on hydrogen; the cost goal is $\$ 30 / \mathrm{kW}$ by 2015 .

- Although comparatively little hydrogen is currently used as fuel or as an energy carrier, the longterm potential is for us to make a transition to a hydrogen-based economy in which hydrogen will join electricity as a major energy carrier. Furthermore, much of the hydrogen will be derived from domestically plentiful renewable energy or fossil resources, making the Hydrogen Economy synonymous with sustainable development and energy security.

- In summary, future fuel cell technology will be characterized by reduced costs and increased reliability for transportation and stationary (power) applications.

- To enable the transition to a hydrogen economy, the cost of hydrogen energy is targeted to be equivalent to gasoline market prices (\$2-3/gallon in 2001 dollars).

- For a fully developed hydrogen energy system, a new hydrogen infrastructure/delivery system will be required.

- In the future, hydrogen also could join electricity as an important energy carrier. An energy carrier stores, moves, and delivers energy in a usable form to consumers. Renewable energy sources, such as the sun or wind, can't produce energy all the time. The sun doesn't always shine nor the wind blow. But hydrogen can store this energy until it is needed and it can be transported to where it is needed.

- Some experts think that hydrogen will form the basic energy infrastructure that will power future societies, replacing today's natural gas, oil, coal, and electricity infrastructures. They see a new hydrogen economy to replace our current energy economies, although that vision probably won't happen until far in the future.

Source: National Renewable Energy Laboratory. U.S. Climate Change Technology Program. Technology Options: For the Near and Long Term. DOE/PI-0002. November 2003 (draft update, September 2005); and National Renewable Energy Laboratory. Gas-Fired Distributed Energy Resource Technology Characterizations. NREL/TP-620/34783. November 2003. 


\section{Advanced Hydropower}

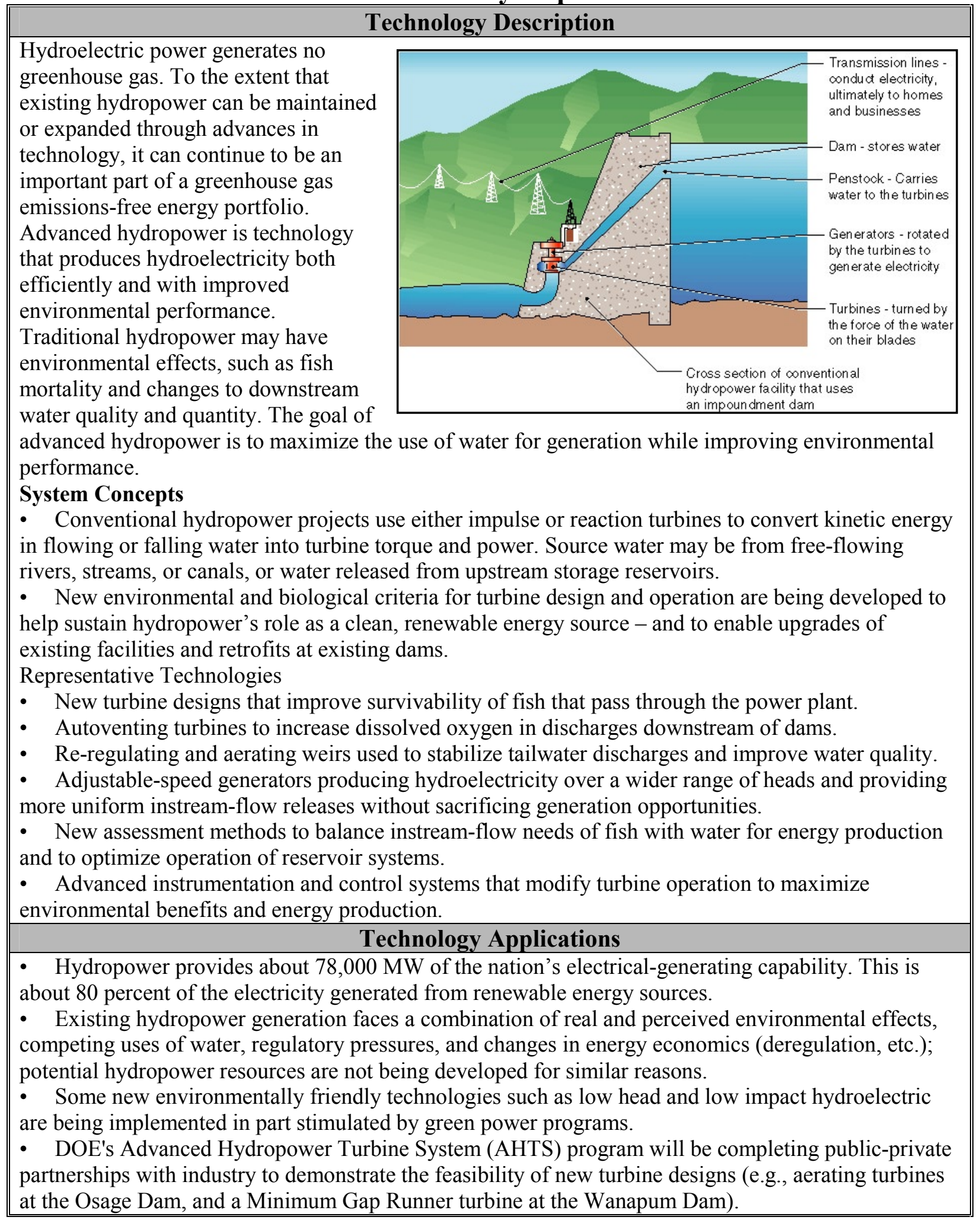




\section{Current Status}

- TVA has demonstrated that improved turbine designs, equipment upgrades, and systems optimization can lead to significant economic and environmental benefits - energy production was increased approximately $12 \%$ while downstream fish resources were significantly improved.

- Field-testing of the Kaplan turbine Minimum Gap Runner design indicates that fish survival can be significantly increased, if conventional turbines are modified. The full complement of Minimum Gap Runner design features will be tested at the Wanapum Dam in FY 2005.

\section{Technology History}

- Since the time of ancient Egypt, people have used the energy in flowing water to operate machinery and grind grain and corn. However, hydropower had a greater influence on people's lives during the 20 th century than at any other time in history. Hydropower played a major role in making the wonders of electricity a part of everyday life and helped spur industrial development. Hydropower continues to produce $24 \%$ of the world's electricity and supply more than 1 billion people with power.

- The first hydroelectric power plant was built in 1882 in Appleton, Wisconsin, to provide 12.5 kilowatts to light two paper mills and a home. Today's hydropower plants generally range in size from several hundred kilowatts to several hundred megawatts, but a few mammoth plants have capacities up to 10,000 megawatts and supply electricity to millions of people.

- By 1920, 25\% of electrical generation in the United States was from hydropower; and, by 1940, it increased to $40 \%$.

- Most hydropower plants are built through federal or local agencies as part of a multipurpose project. In addition to generating electricity, dams and reservoirs provide flood control, water supply, irrigation, transportation, recreation, and refuges for fish and birds. Private utilities also build hydropower plants, although not as many as government agencies.

\section{Technology Future}

- Voith Siemens Hydro Power and the TVA have established a partnership to market environmentally friendly technology at hydropower facilities. Their products were developed partly by funding provided by DOE and the Corps of Engineers, as well as private sources.

- In a competitive solicitation, DOE accepted proposals for advanced turbine designs from Voith Siemens, Alstom, American Hydro, and General Electric Co. Field verification and testing is underway with some of these designs to demonstrate improved environmental performance.

- Flash Technology is developing strobe lighting systems to force fish away from hydropower intakes and to avoid entrainment mortality in turbines. Implementation at more sites may allow improved environmental performance with reduced spillage.

Market Context

- Advanced hydropower products can be applied at more than $80 \%$ of existing hydropower projects (installed conventional capacity is now $94 \mathrm{GW}$ ); the potential market also includes $15-20 \mathrm{GW}$ at existing dams (i.e. no new dams required for development) and more than $30 \mathrm{GW}$ of undeveloped hydropower.

- Retrofitting advanced technology and optimizing system operations at existing facilities would lead to at least a $6 \%$ increase in energy output - if fully implemented, this would equate to $5 \mathrm{GW}$ and $18,600 \mathrm{GWh}$ of new, clean energy production.

Source: National Renewable Energy Laboratory. U.S. Climate Change Technology Program. Technology Options: For the Near and Long Term. DOE/PI-0002. November 2003 (draft update, September 2005). 


\section{Hydroelectric Power \\ Market Data}

\begin{tabular}{|c|c|c|c|c|c|c|c|c|c|c|c|c|}
\hline U.S. Installed Capacity (MW)* & Source: & newable & Electric & ant Inforr & ation Sy & tem $(R E$ & iS), Ver & on $7, \mathrm{NR}$ & L, 2003. & & & \\
\hline & 1980 & 1985 & 1990 & 1995 & 1996 & 1997 & 1998 & 1999 & 2000 & 2001 & 2002 & 2003 \\
\hline Annual & 1,391 & 3,237 & 862 & 1,054 & 19.9 & 64.0 & 7.6 & 179.3 & 1.1 & 11 & 0.002 & 21.0 \\
\hline Cumulative & 80,491 & 87,839 & 90,955 & 94,052 & 94,072 & 94,136 & 94,143 & 94,323 & 94,324 & 94,335 & 94,335 & 94,356 \\
\hline
\end{tabular}

* There are an additional $21 \mathrm{MW}$ of hydroelectric capacity that are not accounted for here because they have no specific online date.

2003 data not complete as REPiS database is updated through 2002.

Cumulative Grid-

Connected Hydro

Capacity (MW) ${ }^{1}$

U.S.

Conventional and

other Hydro

Pumped Storage ${ }^{2}$

U.S. Hydro Total

OECD Europe ${ }^{3}$

IEA Europe ${ }^{4}$

Japan

OECD Total

IEA Total

World Total
Source: U.S. data from EIA, AER 2004, Table 8.11a; World Total from EIA, International Energy Annual, 1996-2003, Table 6.4. International data from International Energy Agency, Electricity Information 2004.

$$
1980
$$$$
1985
$$$$
1990
$$$$
1995
$$$$
1996
$$$$
1997
$$$$
1998
$$$$
1999
$$$$
2000
$$$$
2002
$$$$
2003
$$

$\begin{array}{rrrrrr}81,700 & 88,900 & 73,923 & 78,562 & 76,437 & 79,415 \\ \text { N/A } & \text { N/A } & 19,462 & 21,387 & 21,110 & 19,310 \\ 81,700 & 88,900 & 93,385 & 99,948 & 97,548 & 98,725 \\ 124,184 & 124,577 & 130,886 & 132,893 & 134,902 & 135,939 \\ 123,960 & 124,357 & 130,663 & 132,666 & 134,038 & 135,074 \\ 21,377 & 19,980 & 20,825 & 21,171 & 21,222 & 21,277 \\ 286,969 & 300,725 & 316,291 & 340,259 & 342,893 & 346,342 \\ 286,745 & 300,505 & 316,068 & 330,703 & 331,947 & 335,395 \\ 470,669 & 537,734 & 600,206 & 650,936 & 661,237 & 673,797\end{array}$

79,151

79,393

19,518

19,565

79,359

79,484

79,354

78,694

78,703

98,669

98,958

19,522

19,096

20,373

20,522

133,307

98,958
136,251

98,881

99,727

$\begin{array}{llll}-136,251 & 140,779 & 141,913 & 147,580\end{array}$

99,216

NA

NA

NA

$\begin{array}{lllll}21,477 & 21,555 & 22,019 & 22,081 & 21,690\end{array}$

$\begin{array}{lllll}342,673 & 346,446 & 351,513 & 352,564 & 338,130\end{array}$

$\begin{array}{lllll}331,930 & 335,768 & 339,145 & 339,880 & 324,920\end{array}$

537,734

600,206

330,703

661,237

673,797

680,610

697,749

$712,689723,581$

NA

NA

NA

NA

20,522

99,225

NA

NA

NA

NA

NA

NA

2. Pumped storage values for 1980-1985 are included in "Conventional and other Hydro"

3. OECD included 24 countries as of 1980. Mexico, Czech Republic, Hungary, Poland, South Korea, Slovak Republic joined after 1980. Countries' data are included only after the year they joined.

4. IEA included 26 countries as of 2003. Countries' data are included only after the year they joined the OECD.

$\mathrm{NA}=$ Not Available; Updated international data not available at time of publication 


\begin{tabular}{|c|c|c|c|c|c|c|c|c|c|c|c|c|}
\hline \multirow{2}{*}{$\begin{array}{l}\text { Annual Generation from } \\
\text { Cumulative Installed Capacity } \\
\text { (Billion kWh) }\end{array}$} & \multicolumn{11}{|c|}{ Source: EIA, International Energy Annual 2003, DOE/EIA-0219(02), Table 1.5. } & \multirow[b]{2}{*}{2002} \\
\hline & & 1980 & 1985 & 1990 & 1995 & 1996 & 1997 & 1998 & 1999 & 2000 & 2001 & \\
\hline United States & & 279 & 284 & 289 & 308 & 344 & 352 & 319 & 313 & 270 & 208 & 255 \\
\hline Canada & & 251 & 301 & 294 & 332 & 352 & 347 & 329 & 342 & 355 & 330 & 315 \\
\hline Mexico & & 17 & 26 & 23 & 27 & 31 & 26 & 24 & 32 & 33 & 28 & 25 \\
\hline Brazil & & & 177 & 205 & 251 & 263 & 276 & 289 & 290 & 302 & 265 & 282 \\
\hline Western Europe & & & 453 & 453 & 506 & 491 & 506 & 523 & 531 & 555 & 553 & 503 \\
\hline Former U.S.S.R. & 12 & & 205 & 231 & 238 & 215 & 216 & 225 & 227 & 228 & 239 & 243 \\
\hline Eastern Europe & 43 & & 26 & 23 & 34 & 34 & 36 & 35 & 35 & 31 & 30 & 32 \\
\hline China & 18 & & 91 & 125 & 184 & 185 & 193 & 203 & 211 & 241 & 258 & 309 \\
\hline Japan & & & 82 & 88 & 81 & 80 & 89 & 92 & 86 & 86 & 83 & 81 \\
\hline Rest of World & 27 & 273 & 328 & 435 & 504 & 515 & 522 & 533 & 541 & 558 & 571 & 581 \\
\hline & 58 & & & & & & & & & & & \\
\hline World Total & 88 & 1,736 & 1,973 & 2,167 & 2,466 & 2,511 & 2,564 & 2,571 & 2,609 & 2,658 & 2,565 & 2,627 \\
\hline
\end{tabular}

\begin{tabular}{|c|c|c|c|c|c|c|c|c|c|c|c|}
\hline \multirow{2}{*}{$\begin{array}{l}\text { State Generating Capability* } \\
\text { (MW) } \\
\text { Top } 10 \text { States }\end{array}$} & \multicolumn{11}{|c|}{$\begin{array}{l}\text { Source: EIA, Electric Power Annual } 2004 \text { - Spreadsheets, "1990 - } 2002 \text { Existing Nameplate and Net Summer } \\
\text { Capacity by Energy Source and Producer Type (EIA-860)" } \\
\text { http://www.eia.doe.gov/cneaf/electricity/epa/existing_capacity_state.xls }\end{array}$} \\
\hline & 1990 & 1995 & 1996 & 1997 & 1998 & 1999 & 2000 & 2001 & 2002 & 2003 & 2004 \\
\hline Washington & 19,935 & 20,487 & 20,431 & 20,923 & 21,012 & 21,011 & 21,011 & 21,006 & 21,016 & 21,018 & 20,941 \\
\hline California & 12,687 & 13,519 & 13,500 & 13,475 & 13,383 & 13,445 & 13,475 & 13,471 & 13,523 & 13,306 & 13,323 \\
\hline Oregon & 8,221 & 8,268 & 8,267 & 8,264 & 8,265 & 8,249 & 8,261 & 8,240 & 8,211 & 8,235 & 8,236 \\
\hline New York & 5,345 & 5,545 & 5,557 & 5,565 & 5,668 & 5,662 & 5,659 & 5,712 & 5,804 & 5,842 & 5,891 \\
\hline Tennessee & 3,717 & 3,818 & 3,818 & 3,937 & 3,950 & 3,950 & 3,950 & 3,948 & 3,948 & 3,948 & 3,948 \\
\hline Georgia & 2,453 & 3,287 & 3,005 & 3,305 & 3,314 & 3,314 & 3,313 & 3,313 & 3,613 & 3,414 & 3,566 \\
\hline South Carolina & 2,367 & 3,468 & 3,468 & 3,442 & 3,442 & 3,452 & 3,455 & 3,453 & 3,453 & 3,459 & 3,499 \\
\hline Virginia & 3,072 & 3,126 & 3,149 & 3,082 & 3,093 & 3,090 & 3,091 & 3,088 & 3,088 & 3,088 & 3,088 \\
\hline Alabama & 2,857 & 2,868 & 2,864 & 2,904 & 2,961 & 2,961 & 2,961 & 2,959 & 2,959 & 3,159 & 3,261 \\
\hline Arizona & 2,685 & 2,885 & 2,885 & 2,893 & 2,893 & 2,890 & 2,890 & 2,890 & 2,893 & 2,899 & 2,903 \\
\hline U.S. Total & 89,828 & 94,513 & 94,372 & 95,222 & 95,496 & 95,802 & 95,879 & 95,844 & 96,343 & 96,353 & 96,699 \\
\hline
\end{tabular}

* Values are nameplate capacity for total electric industry 


\begin{tabular}{|c|c|c|c|c|c|c|c|c|c|c|c|}
\hline $\begin{array}{l}\text { State Annual Generation from } \\
\text { Cumulative Installed Capacity* } \\
\text { (Billion kWh) }\end{array}$ & \multicolumn{11}{|c|}{$\begin{array}{l}\text { Source: EIA, Electric Power Annual } 2002 \text { - Spreadsheets, "1990 - } 2002 \text { Net Generation by State by Type of } \\
\text { Producer by Energy Source (EIA-906)" http://www.eia.doe.gov/cneaf/electricity/epa/generation_state.xls }\end{array}$} \\
\hline Top 10 States & 1990 & 1995 & 1996 & 1997 & 1998 & 1999 & 2000 & 2001 & 2002 & 2003 & 2004 \\
\hline Washington & 87.5 & 82.5 & 98.5 & 104.2 & 79.8 & 97.0 & 80.3 & 54.7 & 78.2 & 71.8 & 71.6 \\
\hline Oregon & 41.2 & 40.8 & 44.9 & 46.7 & 39.9 & 45.6 & 38.1 & 28.6 & 34.4 & 33.3 & 33.1 \\
\hline California & 24.8 & 50.5 & 46.9 & 42.1 & 50.8 & 40.4 & 39.3 & 25.2 & 30.9 & 36.4 & 34.1 \\
\hline New York & 27.1 & 24.8 & 27.8 & 29.5 & 28.2 & 23.6 & 23.9 & 22.2 & 24.1 & 24.3 & 24.0 \\
\hline Montana & 10.7 & 10.7 & 13.8 & 13.4 & 11.1 & 13.8 & 9.6 & 6.6 & 9.6 & 8.7 & 8.9 \\
\hline Alabama & 10.4 & 9.5 & 11.1 & 11.5 & 10.6 & 7.8 & 5.8 & 8.4 & 8.8 & 12.7 & 10.6 \\
\hline Idaho & 9.1 & 11.0 & 13.3 & 14.7 & 12.9 & 13.5 & 11.0 & 7.2 & 8.8 & 8.4 & 8.5 \\
\hline Arizona & 7.7 & 8.5 & 9.5 & 12.4 & 11.2 & 10.1 & 8.6 & 7.9 & 7.6 & 7.1 & 7.0 \\
\hline Tennessee & 9.5 & 9.0 & 10.8 & 10.4 & 10.2 & 7.2 & 5.7 & 6.2 & 7.3 & 12.0 & 10.4 \\
\hline South Dakota & 3.9 & 6.0 & 8.0 & 9.0 & 5.8 & 6.7 & 5.7 & 3.4 & 4.4 & 4.3 & 3.6 \\
\hline U.S. Total & 289.4 & 308.1 & 344.1 & 352.4 & 318.9 & 313.4 & 270.0 & 208.1 & 255.6 & 275.8 & 268.4 \\
\hline
\end{tabular}

* Values are for total electric industry. Years before 1998 do not include nonutility generation.

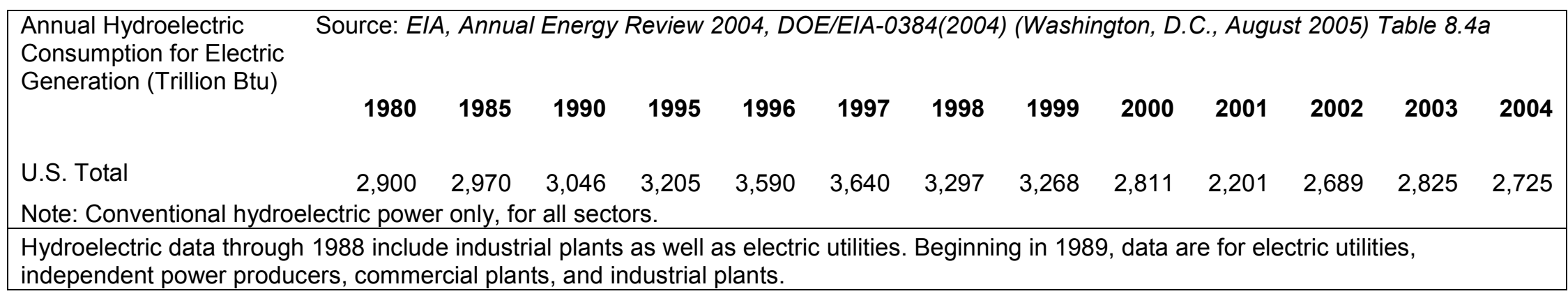




\section{Building Technologies}

\section{Technology Description}

\section{Building equipment}

Energy use in buildings depends on equipment to transform fuel or electricity into end-use services such as delivered heat or cooling, light, fresh air, vertical transport, cleaning of clothes or dishes, and information processing. There are energy-saving opportunities within individual pieces of equipment - as well as at the system level - through proper sizing, reduced distribution and standby losses, heat recovery and storage, and optimal control.

\section{Building envelope}

The building envelope is the interface between the interior of a building and the outdoor environment. In most buildings, the envelope - along with the

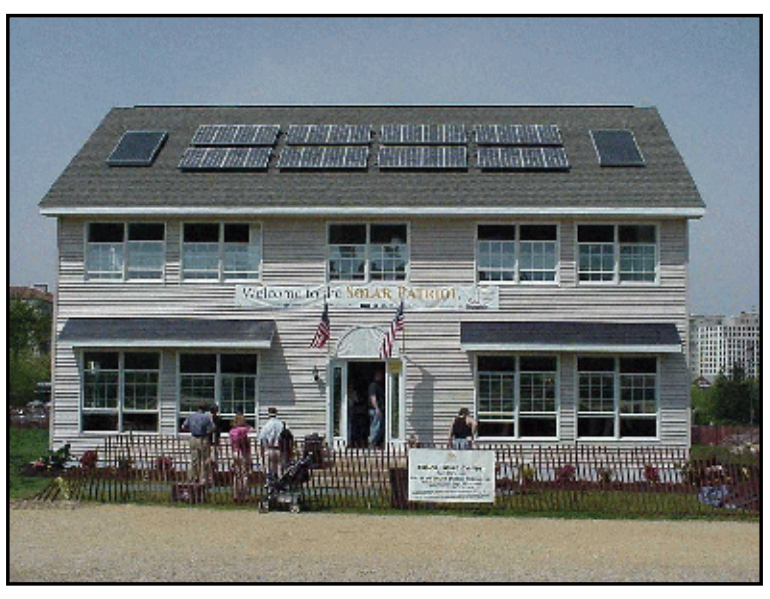
outdoor weather - is the primary determinant of the amount of energy used to heat, cool, and ventilate. A more energy-efficient envelope means lower energy use in a building and lower greenhouse gas emissions. The envelope concept can be extended to that of the "building fabric," which includes the interior partitions, ceilings, and floors. Interior elements and surfaces can be used to store, release, control, and distribute energy, thereby further increasing the overall efficiency of the buildings.

\section{Whole building integration}

Whole building integration uses data from design (together with sensed data) to automatically configure controls and commission (i.e., start-up and check out) and operate buildings. Control systems use advanced, robust techniques and are based on smaller, less expensive, and much more abundant sensors. These data ensure optimal building performance by enabling control of building systems in an integrated manner and continuously recommissioning them using automated tools that detect and diagnose performance anomalies and degradation. Whole building integration systems optimize operation across building systems, inform and implement energy purchasing, guide maintenance activities, document and report building performance, and optimally coordinate on-site energy generation with building energy demand and the electric power grid, while ensuring that occupant needs for comfort, health, and safety were met at the lowest possible cost.

\section{System Concepts}

\section{Building equipment}

- Major categories of end-use equipment include heating, cooling, and hot water; ventilation and thermal distribution; lighting; home appliances; miscellaneous (process equipment and consumer products); and on-site energy and power.

- Key components vary by type of equipment, but some crosscutting opportunities for efficiency include improved materials, efficient low-emissions combustion and heat transfer, advanced refrigerants and cycles, electrodeless and solid-state lighting, smart sensors and controls, improved small-power supplies, variable-capacity systems, reduction of thermal and electrical standby losses, cogeneration based on modular fuel cells and microturbines, and utilization of waste heat from fuel cells and microturbines.

\section{Building envelope}

- Control of envelope characteristics provides control over the flow of heat, air, moisture, and light into the building. These flows and the interior energy and environmental loads determine the size and energy use of HVAC and distribution systems. 
- Materials for exterior walls, roofs, foundations, windows, doors, interior partition walls, ceilings, and floors that can impact future energy use include insulation with innovative formula foams and vacuum panels; optical control coatings for windows and roofs; and thermal storage materials, including lightweight heat-storage systems.

\section{Whole building integration}

- The system consists of design tools, automated diagnostics, interoperable control-system components, abundant wireless sensors and controls, and highly integrated operation of energy-using and producing systems.

- These components would work together to collect data, configure controls, monitor operations, optimize control, and correct out-of-range conditions that contribute to poor building performance. Whole building integration would ensure that essential information - especially the design intent and construction implementation data - would be preserved and shared across many applications throughout the lifetime of the building.

- Equipment and system performance records would be stored as part of a networked building performance knowledge base, which would grow over time and provide feedback to designers, equipment manufacturers, and building operators and owners.

- Optimally integrate on-site power production with building energy needs and the electric-power grid by applying intelligent control to building cooling, heating, and power.

\section{Representative Technologies}

\section{Building equipment}

- Residential gas-fired absorption heat pumps, centrifugal chillers, desiccant preconditioners for treating ventilation air, heat-pump water heaters, proton exchange membrane fuel cells, heat pump water heaters, solid-state lighting, and lighting controls.

- Specialized HVAC (heating, ventilating, and air-conditioning) systems for research laboratories, server/data systems, and other buildings housing high-technology processes.

\section{Building envelope}

- Superinsulation: Vacuum powder-filled, gas-filled, and vacuum fiber-filled panels; structurally reinforced beaded vacuum panels; and switchable evacuated panels with insulating values more than four times those of the best currently available materials should soon be available for niche markets. High-thermal-resistant foam insulations with acceptable ozone depletion and global warming characteristics should allow for continued use of this highly desirable thermal insulation.

- Advanced window systems: Krypton-filled, triple-glazed, low-E windows; electrochromic glazing; and hybrid electrochromic/photovoltaic films and coatings should provide improved lighting and thermal control of fenestration systems. Advanced techniques for integration, control, and distribution of daylight should significantly reduce the need for electric lighting in buildings. Self-drying wall and roof designs should allow for improved insulation levels and increase the lifetimes for these components. More durable high-reflectance coatings should allow better control of solar heat on building surfaces.

- Advanced thermal storage materials: Dry phase-change materials and encapsulated materials should allow significant load distribution over the full diurnal cycle and significant load reduction when used with passive solar systems.

\section{Whole building integration}

- DOE is developing computer-based building commissioning and operation tools to improve the energy efficiency of "existing" buildings. It is also investing in the next generation of buildingsimulation programs that could be integrated into design tools.

- DOE, in collaboration with industry, also is developing and testing technologies for combined cooling, heating, and power; and wireless sensor and control systems for buildings. 


\section{Technology Applications}

\section{Building equipment}

- Technology improvements during the past 20 years - through quality engineering, new materials, and better controls - have improved efficiencies in lighting and equipment by $15 \%$ to $75 \%$, depending on the type of equipment. Efficiencies of compact fluorescent lamps are $70 \%$ better than incandescent lamps; refrigerator energy use has been reduced by more than three-quarters during the past 20 years; $\mathrm{H}$-axis clothes washers are 50\% more efficient than current minimum standards. Electronic equipment has achieved order-of-magnitude efficiency gains, at the microchip level, every two to three years.

\section{Building envelope}

- Building insulations have progressed from the $2-4 \mathrm{hr}^{\circ} \mathrm{F} \mathrm{ft} / \mathrm{Btu} / \mathrm{in}$. fibrous materials available before 1970 to foams reaching $7 \mathrm{hr}^{\circ} \mathrm{F} \mathrm{ft} / \mathrm{Btu} / \mathrm{in}$. Superinsulations of more than $25^{\circ} \mathrm{F} \mathrm{ft}^{2} / \mathrm{Btu} / \mathrm{in}$. will be available for niche markets soon. Improvements in window performance have been even more spectacular. In the 1970s, window thermal resistance was 1 to $2^{\circ} \mathrm{F} \mathrm{ft}^{2} / \mathrm{Btu}$. Now, new windows have thermal resistance of up to $6^{\circ} \mathrm{F} \mathrm{ft} / \mathrm{Btu}$ (whole window performance). Windows are now widely available with selective coatings that reduce infrared transmittance without reducing visible transmittance. In addition, variable-transmittance windows under development will allow optimal control to minimize heating, cooling, and lighting loads.

\section{Whole building integration}

- Savings from improved operation and maintenance procedures could save more than $30 \%$ of the annual energy costs of existing commercial buildings, even in many of those buildings thought to be working properly by their owners/operators. These technologies would have very short paybacks, because they would ensure that technologies were performing as promised, for a fraction of the cost of the installed technology.

- Savings for new buildings could exceed $70 \%$, using integration of building systems; and, with combined cooling, heating and power, buildings could become net electricity producers and distributed suppliers to the electric power grid.

\section{Current Status}

\section{Building equipment}

- Recent DOE-sponsored R\&D, often with industry participation, includes an improved airconditioning cycle to reduce oversizing and improve efficiency; a replacement for inefficient, hightemperature halogen up-lights (torchieres), which use only $25 \%$ of the power, last longer, and eliminate potential fire hazards; ozone-safe refrigerants, where supported R\&D was directed toward lubrication materials problems associated with novel refrigerants and ground-source heat pumps.

\section{Building envelope}

- A DOE-sponsored RD\&D partnership with the Polyisocyanurate Insulation Manufacturers Association, the National Roofing Contractors Association, the Society of the Plastics Industry, and Environmental Protection Agency (EPA) helped the industry find a replacement for chloroflurocarbons (CFCs) in polyisocyanurate foam insulation. This effort enabled the buildings industry to transition from CFC-11 to HCFC-141b by the deadline required by the Montreal protocol.

- Spectrally selective window glazings - which reduce solar heat gain and lower cooling loads - and high-performance insulating materials for demanding thermal applications are available.

\section{Whole building integration}

- Energy 10 models passive solar systems in buildings.

- DOE-2: international standard for whole building energy performance simulation has thousands of users. DOE released Energy Plus, new standard for building energy simulation and DOE-2 successor.

- The International Alliance for Interoperability is setting international standards for interoperability of computer tools and components for buildings.

- DOE-BESTEST is the basis for ANSI/ASHRAE Standard 140, Method of Test for the Evaluation of Building Energy Simulation Programs. 


\section{Technology History}

- 1890 s - First commercially available solar water heaters produced in southern California. Initial designs were roof-mounted tanks and later glazed tubular solar collectors in thermosiphon configuration. Several thousand systems were sold to homeowners.

- 1900 s - Solar water-heating technology advanced to roughly its present design in 1908 when William J. Bailey of the Carnegie Steel Company, invented a collector with an insulated box and copper coils.

- 1940 s - Bailey sold 4,000 units by the end of WWI, and a Florida businessperson who bought the patent rights sold nearly 60,000 units by 1941 .

- 1950 s - Industry virtually expires due to inability to compete against cheap and available natural gas and electric service.

- 1970 s - The modern solar industry began in response to the OPEC oil embargo in 1973-74, with a number of federal and state incentives established to promote solar energy. President Jimmy Carter put solar water-heating panels on the White House. FAFCO, a California company specializing in solar pool heating; and Solaron, a Colorado company that specialized in solar space and water heating, became the first national solar manufacturers in the United States. In 1974, more than 20 companies started production of flat-plate solar collectors, most using active systems with antifreeze capabilities. Sales in 1979 were estimated at 50,000 systems. In Israel, Japan, and Australia, commercial markets and manufacturing had developed with fairly widespread use.

- 1980 s - In 1980, the Solar Rating and Certification Corp (SRCC) was established for testing and certification of solar equipment to meet set standards. In 1984, the year before solar tax credits expired, an estimated 100,000-plus solar hot-water systems were sold. Incentives from the 1970s helped create the 150-business manufacturing industry for solar systems with more than $\$ 800$ million in annual sales by 1985 . When the tax credits expired in 1985, the industry declined significantly. During the Gulf War, sales again increased by about $10 \%$ to $20 \%$ to its peak level, more than 11,000 square feet per year (sq.ft./yr) in 1989 and 1990.

- $1990 \mathrm{~s}$ - Solar water-heating collector manufacturing activity declined slightly, but has hovered around 6,000 to 8,000 sq.ft./yr. Today's industry represents the few strong survivors: More than 1.2 million buildings in the United States have solar water-heating systems, and 250,000 solar-heated swimming pools exist. Unglazed, low-temperature solar water heaters for swimming pools have been a real success story, with more than a doubling of growth in square footage of collectors shipped from 1995 to 2001.

Reference: American Solar Energy Society and Solar Energy Industry Association 


\section{Technology Future}

\section{Building equipment}

- Building equipment, appliances, and lighting systems currently on the market vary from $20 \%$ to $100 \%$ efficient (heat pumps can exceed this level by using "free" energy drawn from the environment). This efficiency range is narrower where cost-effective appliance standards have previously eliminated the least-efficient models.

- The stock and energy intensity of homes are growing faster than the building stock itself, as manufacturers introduce - and consumers and businesses eagerly accept - new types of equipment, more sophisticated and automated technologies, and increased levels of end-use services.

- The rapid turnover and growth of many types of building equipment - especially electronics for computing, control, communications, and entertainment - represent important opportunities to rapidly introduce new, efficient technologies and quickly propagate them throughout the stock.

- The market success of most new equipment and appliance technologies is virtually ensured if the efficiency improvement has a 3-year payback or better and amenities are maintained; technologies with payback of 4 to 8-plus years also can succeed in the market, provided that they offer other customervalued features (e.g., reliability, longer life, improved comfort or convenience, quiet operation, smaller size, lower pollution levels).

- Applications extend to every segment of the residential and nonresidential sectors. Major government, institutional, and corporate buyers represent a special target group for voluntary early deployment of the best new technologies.

- Building equipment and appliances represent an annual market in the United States, alone, of more than $\$ 200 \mathrm{~B}$, involving thousands of large and small companies. Certain technologies, such as office and home electronics, compete in global markets with little or no change in performance specifications.

\section{Building envelope}

- A critical challenge is to ensure that new homes and buildings are constructed with good thermal envelopes and windows when the technologies are most cost-effective to implement.

- The market potential is significant for building owners taking some actions to improve building envelopes. Currently, $40 \%$ of residences are well insulated, $40 \%$ are adequately insulated, and $20 \%$ are poorly insulated. More than $40 \%$ of new window sales are of advanced types (low-E and gas-filled). In commercial buildings, more than $17 \%$ of all windows are advanced types. More than $70 \%$ of commercial buildings have roof insulation; somewhat fewer have insulated walls.

- Building products are mostly commodity products. A number of companies produce them; and each has a diverse distribution system, including direct sales, contractors, retailers, and discount stores. Another critical challenge is improving the efficiency of retrofits of existing buildings. Retrofitting is seldom cost-effective on a stand-alone basis. New materials and techniques are required.

- Many advanced envelope products are cost-competitive now, and new technologies will become so on an ongoing basis. There will be modest cost reductions over time as manufacturers compete.

- Building structures represent an annual market in the United States of more than $\$ 70 \mathrm{~B} /$ year and involve thousands of large and small product manufacturers and a large, diverse distribution system that plays a crucial role in product marketing. Exporting is not an important factor in the sales of most building structure products.

\section{Whole building integration}

- The future vision of buildings technologies is one of "net zero energy" buildings which use a combination of integrated electricity generation--such as photovoltaics--paired with energy efficiency and power controls, to create a building that on average during a year produces enough energy for all the energy demands within the building.

- Design tools for energy efficiency are used by fewer than $2 \%$ of the professionals involved in the design, construction, and operation of commercial buildings in the United States. A larger fraction of commercial buildings have central building-control systems. Few diagnostic tools are available commercially beyond those used for air-balancing or integrated into equipment (e.g., Trane Intellipack 
System) and the recently announced air-conditioning diagnostic hand-held service tool by Honeywell (i.e. Honeywell HVAC Service Assistant).

- The Department of Energy - in concert with the California Energy Commission - is testing a number of automated diagnostic tools and techniques with commercial building owners, operators, and service providers in an effort to promote commercial use. About 12 software vendors develop, support, and maintain energy design tools; most are small businesses. Another 15 to 20 building automation and control vendors exist in the marketplace - the major players include Johnson Controls, Honeywell, and Siemens.

- Deployment involves four major aspects: seamless integration into existing building design and operation practices and platforms, lowering the cost of intelligent-building and enabling technologies, transforming markets to rapidly introduce new energy-efficient technologies, and a focus on conveying benefits that are desired in the marketplace (not only energy efficiency).

- These technologies would apply to all buildings, but especially to existing commercial buildings and all new buildings. In addition, new technologies would be integrated into the building design and operation processes.

Source: National Renewable Energy Laboratory. U.S. Climate Change Technology Program. Technology Options: For the Near and Long Term. DOE/PI-0002. November 2003 (draft update, September 2005).

For more data on the Buildings sector, please refer to the "Buildings Energy Data Book" which is a comprehensive collection of buildings- and energy-related data. The Buildings Energy Data Book is available online at http://buildingsdatabook.eren.doe.gov/ 


\section{Solar Buildings}

\section{Market Data}

U.S. Installations

(Thousands of Sq. Ft.)

Source: EIA, Renewable Energy Annual 2004, Table 38, REA 2003 Table 18 and Table 10; REA 2002, Table 18; REA 1997- 2000, Table 16; REA 1996, Table 18

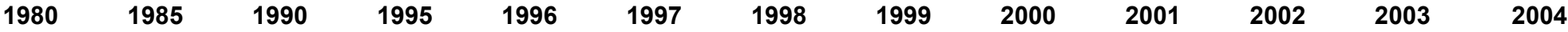

Annual

Hot Water

Pool Heaters

Total Solar Thermal 1

1995

1998

423

511

452

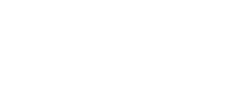

\section{Cumulative}

Hot Water

18,283

19,166

${ }^{11,164}{ }_{6,763} 7,136$

$\begin{array}{rrr}765 & 595 & 463 \\ 6,787 & 7,528 & 7,201\end{array}$

$8,141 \quad 7,863$

$\begin{array}{rr}274 & 423 \\ 10,797 & 11,073\end{array}$

10,800

13,634

$7,162 \quad 7,759 \quad 7,396$

8,046

7,857

10,349

11,004

10,926

14,114

Pool Heaters

$\begin{array}{cccc}755 & 1,520 & 2,115 & 2,578 \\ 6,763 & 13,550 & 21,078 & 28,279 \\ 233,386 & 240,548 & 248,307 & 255,703 \\ \text { nts } & & & \end{array}$

\section{2,951}

3,318

\section{3,592}

36,420

44,283

$62,829 \quad 153,035 \quad 199,459 \quad 233,386$

36,420

271,606

55,080

4,015

66,153

4,526

4,978

Total Solar Thermal 1

1. Domestic shipments - total shipments minus export shipments

U.S. Annual Shipments

Source: EIA, Renewable Energy Annual 2003, Table 11; and REA 1999, Table 11.

(Thousand Sq. Ft.)

\section{Total}

Imports

Exports

$\begin{array}{rrrrrrrrrrrrr}1980 & \mathbf{1 9 8 5} & \mathbf{1 9 9 0} & \mathbf{1 9 9 5} & \mathbf{1 9 9 6} & \mathbf{1 9 9 7} & \mathbf{1 9 9 8} & \mathbf{1 9 9 9} & \mathbf{2 0 0 0} & \mathbf{2 0 0 1} & \mathbf{2 0 0 2} & \mathbf{2 0 0 3} & \mathbf{2 0 0 4} \\ 19,398 & \mathrm{~N} / \mathrm{A} & 11,409 & 7,666 & 7,616 & 8,138 & 7,756 & 8,583 & 8,354 & 11,189 & 11,663 & 11,444 & 14,114 \\ & \text { N/A } & 1,562 & 2,037 & 1,930 & 2,102 & 2,206 & 2,352 & 2,201 & 3,502 & 3,068 & 2,986 & 3,723 \\ 1,115 & \text { N/A } & 245 & 530 & 454 & 379 & 360 & 537 & 496 & 840 & 659 & 518 & 813\end{array}$

U.S. Shipments by Cell

Type (Thousand sq. ft.)

Low-Temperature
Collectors
Medium-Temperature
Collectors
High-Temperature
Collectors
Total

$\begin{array}{rrrrrrrrrrrrr}1980 & 1985 & 1990 & 1995 & 1996 & \mathbf{1 9 9 7} & \mathbf{1 9 9 8} & \mathbf{1 9 9 9} & \mathbf{2 0 0 0} & \mathbf{2 0 0 1} & \mathbf{2 0 0 2} & \mathbf{2 0 0 3} & \mathbf{2 0 0 4} \\ 12,233 & \text { N/A } & 3,645 & 6,813 & 6,821 & 7,524 & 7,292 & 8,152 & 7,948 & 10,919 & 11,126 & 10,877 & 13,608 \\ 7,165 & \text { N/A } & 2,527 & 840 & 785 & 606 & 443 & 427 & 400 & 268 & 535 & 560 & 506 \\ & & & & & & & & & & & \\ \text { N/A } & \text { N/A } & 5,237 & 13 & 10 & 7 & 21 & 4 & 5 & 2 & 2 \\ 19,398 & \text { N/A } & 11,409 & 7,666 & 7,616 & 8,137 & 7,756 & 8,583 & 8,353 & 11,189 & 11,661 & 11,444 & 14,114\end{array}$




\begin{tabular}{|c|c|c|c|c|c|c|c|c|c|c|}
\hline \multirow{2}{*}{$\begin{array}{l}\text { U.S. Shipments of High-Temperature } \\
\text { Collectors by Market Sector, and End } \\
\text { Use (Thousands of Sq. Ft.) }\end{array}$} & \multicolumn{10}{|c|}{$\begin{array}{l}\text { Source: EIA, Renewable Energy Annual 2003, Table 18; REA 2002, Table 18; REA 1996, Table F9; } \\
\text { REA 1997, 1999-2000, Table 16; and REA 1998, Table } 19 .\end{array}$} \\
\hline & 1995 & 1996 & 1997 & 1998 & 1999 & 2000 & 2001 & 2002 & 2003 & 2004 \\
\hline Market Sector & 0 & 0 & 0 & 0 & 0 & & 0 & 0 & 0 & 0 \\
\hline Residential & 1 & 7 & 7 & 18 & 0 & & 1 & 2 & 7 & 0 \\
\hline Commercial & 0 & 2 & 0 & 0 & 0 & & 0 & 0 & 0 & 0 \\
\hline Industrial & 9 & 0 & 0 & 2 & 4 & & 1 & 0 & 0 & 0 \\
\hline Utility & 3 & 0 & 0 & 1 & 0 & & 0 & 0 & 0 & 0 \\
\hline Other & 13 & 10 & 7 & 21 & 4 & & 2 & 2 & 7 & 0 \\
\hline \multicolumn{11}{|l|}{ Total } \\
\hline End Use & 0 & 0 & 0 & 0 & 0 & & 0 & 0 & 0 & 0 \\
\hline Pool Heating & 0 & 7 & 7 & 18 & 0 & & 0 & 0 & 0 & 0 \\
\hline Hot Water & 0 & 0 & 0 & 0 & 0 & & 0 & 0 & 0 & 0 \\
\hline Space Heating & 1 & 0 & 0 & 0 & 0 & & 0 & 0 & 0 & 0 \\
\hline Space Cooling & 0 & 0 & 0 & 0 & 0 & & 0 & 2 & 7 & 0 \\
\hline Combined Space and Water Heating & 0 & 2 & 0 & 0 & 0 & & 0 & 0 & 0 & 0 \\
\hline Process Heating & 9 & 0 & 0 & 2 & 4 & & 2 & 0 & 0 & 0 \\
\hline Electricity Generation & 2 & 0 & 0 & 1 & 0 & & 0 & 0 & 0 & 0 \\
\hline Other & 13 & 10 & 7 & 21 & 4 & & 2 & 2 & 7 & 0 \\
\hline $\begin{array}{l}\text { Total } \\
2000 \text { data not published by EIA }\end{array}$ & 0 & 0 & 0 & 0 & 0 & & 0 & 0 & 0 & 0 \\
\hline
\end{tabular}




\begin{tabular}{|c|c|c|c|c|c|c|c|c|c|c|}
\hline \multicolumn{2}{|c|}{$\begin{array}{l}\text { U.S. Shipments of Medium- Temperature Collectors by } \\
\text { Market Sector, and End Use (Thousands of Sq. Ft.) }\end{array}$} & \multicolumn{9}{|c|}{$\begin{array}{l}\text { Source: EIA, Renewable Energy Annual 2003, Table 18; REA 2002, Table 18; REA } \\
\text { 1996, Table F9; REA 1997, 1999-2000, Table 16; and REA 1998, Table } 19 .\end{array}$} \\
\hline & 1995 & 1996 & 1997 & 1998 & 1999 & 2000 & 2001 & 2002 & 2003 & 2004 \\
\hline \multicolumn{11}{|l|}{ Market Sector } \\
\hline Residential & 774 & 728 & 569 & 355 & 366 & & 238 & 481 & 507 & 478 \\
\hline Commercial & 51 & 50 & 35 & 70 & 59 & & 23 & 69 & 44 & 0 \\
\hline Industrial & 12 & 1 & 0 & 18 & 0 & & 5 & 60 & 0 & 26 \\
\hline Utility & 0 & 0 & 0 & 0 & & & 0 & 4 & 0 & 0 \\
\hline Other & 3 & 7 & 2 & 0 & & & 1 & 1 & 2 & 3 \\
\hline Total & 839 & 786 & 606 & ${ }^{443} 0$ & 426 & & 268 & 614 & 553 & 507 \\
\hline \multicolumn{11}{|l|}{ End Use } \\
\hline Pool Heating & 32 & 21 & 11 & 36 & 12 & & 16 & 28 & 22 & 33 \\
\hline Hot Water & 743 & 754 & 588 & 384 & 373 & & 231 & 421 & 510 & 452 \\
\hline Space Heating & 62 & 6 & 2 & 13 & 24 & & 9 & 145 & 4 & 6 \\
\hline Space Cooling & 0 & 0 & 0 & 0 & & & 0 & 0 & 0 & 0 \\
\hline Combined Space and Water Heating & 2 & 2 & 3 & 8 & 16 & & 12 & 15 & 16 & 16 \\
\hline Process Heating & 0 & 1 & 0 & $0_{0}$ & & & 0 & 4 & 0 & 0 \\
\hline Electricity Generation & 0 & 0 & 0 & 0 & & & 0 & 0 & 0 & 0 \\
\hline Other & 0 & 0 & 1 & 1 & & & 0 & 0 & 0 & 0 \\
\hline Total & 839 & 784 & 605 & $442^{0}$ & 427 & & 268 & 614 & 553 & 507 \\
\hline
\end{tabular}




\begin{tabular}{|c|c|c|c|c|c|c|c|c|c|c|}
\hline \multicolumn{2}{|c|}{$\begin{array}{l}\text { U.S. Shipments of Low- Temperature Collectors } \\
\text { by Market Sector, and End Use (Thousands of } \\
\text { Sq. Ft.) }\end{array}$} & \multicolumn{9}{|c|}{$\begin{array}{l}\text { Source: EIA, Renewable Energy Annual 2003, Table 18; REA 2002, Table 18; REA } \\
\text { 1996, Table F9; REA 1997, 1999-2000, Table 16; and REA 1998, Table } 19 .\end{array}$} \\
\hline & 1995 & 1996 & 1997 & 1998 & 1999 & 2000 & 2001 & 2002 & 2003 & 2004 \\
\hline \multicolumn{11}{|l|}{ Market Sector } \\
\hline Residential & 6,192 & 6,146 & 6,791 & 6,810 & 7,408 & & 9,885 & 10,519 & 9,993 & 12,386 \\
\hline Commercial & 552 & 625 & 726 & 429 & 726 & & 987 & 524 & 813 & 1,178 \\
\hline Industrial & 69 & 51 & 7 & 44 & 18 & & 12 & 2 & 71 & 44 \\
\hline Utility & 0 & 0 & 0 & 0 & 0 & & 0 & 0 & 0 & 0 \\
\hline Other & 0 & 0 & 0 & 2 & 0 & & 34 & 0 & 0 & 0 \\
\hline Total & 6,813 & 6,822 & 7,524 & 7,285 & 8,152 & & 10,919 & 11,046 & 10,877 & 13,608 \\
\hline \multicolumn{11}{|l|}{ End Use } \\
\hline Pool Heating & 6,731 & 6,766 & 7,517 & 7,164 & 8,129 & & 10,782 & 11,045 & 10,778 & 13,600 \\
\hline Hot Water & 11 & 4 & 0 & 60 & 0 & & 42 & 1 & 0 & 0 \\
\hline Space Heating & 70 & 51 & 7 & 53 & 18 & & 61 & 0 & 65 & 8 \\
\hline Space Cooling & 0 & 0 & 0 & 0 & 0 & & 0 & 0 & 0 & 0 \\
\hline Combined Space and Water Heating & & & & & & & & & & 0 \\
\hline Process Heating & 0 & 0 & 0 & 0 & 5 & & 34 & 0 & 34 & 0 \\
\hline Electricity Generation & 0 & 0 & 0 & 0 & 0 & & 0 & 0 & 0 & 0 \\
\hline Other & 0 & 0 & 0 & 0 & 0 & & 0 & 0 & 0 & 0 \\
\hline Total & 6,813 & 6,821 & 7,524 & 7,285 & 8,152 & & 10,919 & 11,046 & 10,877 & 13,608 \\
\hline
\end{tabular}




\section{Technology Performance}

\begin{tabular}{|c|c|c|c|c|c|c|c|c|c|}
\hline Energy Production & \multicolumn{9}{|c|}{$\begin{array}{l}\text { Source: Arthur D. Little, Review of FY } 2001 \text { Office of Power Technology's Solar Buildings Program Planning Unit } \\
\text { Summary, December } 1999 .\end{array}$} \\
\hline \multicolumn{10}{|l|}{ Energy Savings } \\
\hline Pool Heater (therms/yr) & & & & & 600 & & & & \\
\hline
\end{tabular}

\begin{tabular}{|c|c|c|c|c|c|c|c|c|c|}
\hline Cost & \multicolumn{9}{|c|}{$\begin{array}{l}\text { Source: Hot-Water Heater data from Arthur D. Little, Water-Heating Situation Analysis, November 1996, page 53, } \\
\text { and Pool-Heater data from Ken Sheinkopf, Solar Today, Nov/Dec 1997, pp. 22-25. }\end{array}$} \\
\hline \multicolumn{10}{|l|}{ Capital Cost* ${ }^{*}$ (System) } \\
\hline Pool Heater & \multicolumn{9}{|c|}{$3,300-4,000$} \\
\hline \multicolumn{10}{|l|}{ O\&M (\$/System-yr) } \\
\hline Domestic Hot-Water Heater & & & & & $5-30$ & & & & \\
\hline
\end{tabular}

* Costs represent a range of technologies, with the lower bounds representing advanced technologies, such as a low-cost polymer integral collector for domestic hot-water heaters, which are expected to become commercially available after 2010.

For more data on the Buildings sector, please refer to the "Buildings Energy Data Book" which is a comprehensive collection of buildings- and energy-related data. The Buildings Energy Data Book is available online at http://buildingsdatabook.eren.doe.gov/ 


\section{Reciprocating Engines}

\section{Technology Description}

Reciprocating engines, also known as internal combustion engines, require fuel, air, compression, and a combustion source to function. They make up the largest share of the small power generation market and can be used in a variety of applications due to their small size, low unit costs, and useful thermal output.

\section{System Concepts}

- Reciprocating engines fall into one of

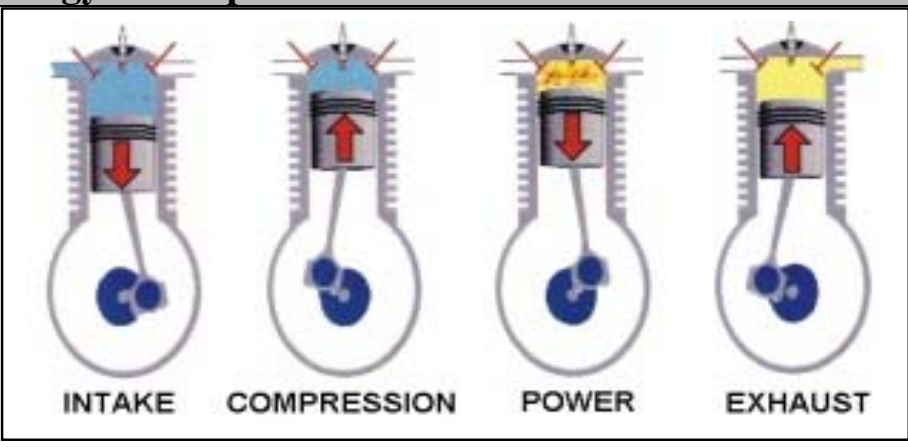

two categories depending on the ignition source: spark ignition (SI), typically fueled by gasoline or natural gas; or compression ignition (CI), typically fueled by diesel oil.

- Reciprocating engines also are categorized by the number of revolutions it takes to complete a combustion cycle. A two-stroke engine completes its combustion cycle in one revolution, and a fourstroke engine completes the combustion process in two revolutions.

\section{Representative Technologies}

- The four-stroke SI engine has an intake, compression, power, and exhaust cycle. In the intake stroke, as the piston moves downward in its cylinder, the intake valve opens and the upper portion of the cylinder fills with fuel and air. When the piston returns upward in the compression cycle, the spark plug fires, igniting the fuel/air mixture. This controlled combustion forces the piston down in the power stroke, turning the crankshaft and producing useful shaft power. Finally, the piston moves up again, exhausting the burnt fuel and air in the exhaust stroke.

- The four-stroke CI engine operates in a similar manner, except diesel fuel and air ignite when the piston compresses the mixture to a critical pressure. At this pressure, no spark or ignition system is needed because the mixture ignites spontaneously, providing the energy to push the piston down in the power stroke.

- The two-stroke engine, whether SI or CI, has a higher power density, because it requires half as many crankshaft revolutions to produce power. However, two-stroke engines are prone to let more fuel pass through, resulting in higher hydrocarbon emissions in the form of unburned fuel.

\section{Technology Applications}

- Reciprocating engines can be installed to accommodate baseload, peaking, emergency or standby power applications. Commercially available engines range in size from $10 \mathrm{~kW}$ to more than $7 \mathrm{MW}$, making them suitable for many distributed-power applications. Utility substations and small municipalities can install engines to provide baseload or peak shaving power. However, the most promising markets for reciprocating engines are on-site at commercial, industrial, and institutional facilities. With fast start-up time, reciprocating engines can play integral backup roles in many building energy systems. On-site reciprocating engines become even more attractive in regions with high electric rates (energy/demand charges).

- When properly treated, the engines can run on fuel generated by waste treatment (methane) and other biofuels.

- By using the recuperators that capture and return waste exhaust heat, reciprocating engines can be used in combined heat and power (CHP) systems to achieve energy efficiency levels approaching $80 \%$. In fact, reciprocating engines make up a large portion of the CHP or cogeneration market.

\section{Current Status}

- Commercially available engines have efficiencies (LHV) between $28 \%$ and $50 \%$ and yield NOx emissions of 0.5-2.0 grams per horsepower hour (hp-hr) for lean-burn natural gas engines and 3.5-6.0 $\mathrm{g} / \mathrm{bhp}-\mathrm{hr}$ for conventional dual-fuel engines. CHP engines achieve efficiencies (LHV) of 70-80\%. 
- Installed cost for reciprocating engines range between $\$ 695$ and $\$ 1,350 / \mathrm{kW}$ depending on size and whether the unit is for a straight generation or cogeneration application. Operating and maintenance costs range $0.8-1.8 ф / \mathrm{kWh}$. Production costs are generally lowest for high-speed engines.

- Exhaust temperature for most reciprocating engines is $700-1,200^{\circ} \mathrm{F}$ in non-CHP mode and 350$500^{\circ} \mathrm{F}$ in a CHP system after heat recovery.

- Noise levels with sound enclosures are typically between 70-80 dB.

- The reciprocating-engine systems typically include several major parts: fuel storage, handling, and conditioning, prime mover (engine), emission controls, waste recovery (CHP systems) and rejections (radiators), and electrical switchgear.

- Annual shipments of reciprocating engines (sized 10MW or less) have almost doubled to $18 \mathrm{GW}$ between 1997 and 2000. The growth is overwhelming in the diesel market, which represented $16 \mathrm{GW}$ shipments compared with $2 \mathrm{GW}$ of natural gas reciprocating engine shipments in 2000 .

- The cost of full maintenance contracts range from 0.7 to 2.0 cents $/ \mathrm{kWh}$. Remote monitoring is now available as a part of service contracts.

(Source: Diesel and Gas Turbine Worldwide, 2003).

Key indicators for stationary reciprocating engines:

\begin{tabular}{|l|l|l|}
\hline $\begin{array}{l}\text { Installed Worldwide } \\
\text { Capacity }\end{array}$ & $\begin{array}{l}\text { Installed US } \\
\text { Capacity }\end{array}$ & $\begin{array}{l}\text { Number of CHP sites using } \\
\text { Recips in the U.S. in 2000 }\end{array}$ \\
\hline $146 \mathrm{GW}$ & $52 \mathrm{GW}$ & 1,055 \\
\hline
\end{tabular}

Sources: Distributed Generation: The Power Paradigm for the New Millenium, 2001; "Gas-Fired Distributed Energy Resource Technology Characterizations (2003)."

\section{Technology History}

- Natural gas-reciprocating engines have been used for power generation since the 1940s. The earliest engines were derived from diesel blocks and incorporated the same components of the diesel engine. Spark plugs and carburetors replaced fuel injectors, and lower compression-ratio pistons were substituted to run the engine on gaseous fuels. These engines were designed to run without regard to fuel efficiency or emission levels. They were used mainly to produce power at local utilities and to drive pumps and compressors.

- In the mid-1980s, manufacturers were facing pressure to lower NOx emissions and increase fuel economy. Leaner air-fuel mixtures were developed using turbochargers and charge air coolers, and in combination with lower in-cylinder fire temperatures, the engines reduced NOx from 20 to $5 \mathrm{~g} / \mathrm{bhp}$-hr. The lower in-cylinder fire temperatures also meant that the BMEP (Brake Mean Effective Pressure) could increase without damaging the valves and manifolds.

- Reciprocating-engine sales have grown more then fivefold from 1988 (2 GW) to 1998 (11.5 GW). Gas-fired engine sales in 1990 were $4 \%$ compared to $14 \%$ in 1998 . The trend is likely to continue for gas-fired reciprocating engines due to strict air-emission regulations and because performance has been steadily improving for the past 15 years.

- More than 35 million reciprocating engine units are produced in North America annually for automobiles, trucks, construction and mining equipment, marine propulsion, lawn care and a diverse range of power-generation applications.

\section{Technology Future}

In 1998, The U.S. Department of Energy - in partnership with the Gas Technology Institute, the Southwest Research Institute, and equipment manufacturers - joined the Advanced Reciprocating Engines Systems (ARES) consortium, aimed at further advancing the performance of the engine. Performance targets include:

High Efficiency-Target fuel-to-electricity conversion efficiency (LHV) is $50 \%$ by 2010. 
Environment - Engine improvements in efficiency, combustion strategy, and emissions reductions will substantially reduce overall emissions to the environments. The NOx target for the ARES program is $0.1 \mathrm{~g} / \mathrm{hp}-\mathrm{hr}$, a $90 \%$ decrease from today's NOx emissions rate.

Fuel Flexibility - Natural gas-fired engines are to be adapted to handle biogas, renewables, propane and hydrogen, as well as dual fuel capabilities.

Cost of Power - The target for energy costs, including operating and maintenance costs, is $10 \%$ less than current state-of-the-art engine systems.

Availability, Reliability, and Maintainability - The goal is to maintain levels equivalent to current stateof-the-art systems.

Other R\&D directions include: new turbocharger methods, heat recovery equipment specific to the reciprocating engine, alternate ignition system, emission-control technologies, improved generator technology, frequency inverters, controls/sensors, higher compression ratio, and dedicated natural-gas cylinder heads.

Source: National Renewable Energy Laboratory. Gas-Fired Distributed Energy Resource Technology Characterizations. NREL/TP-620-34783. November 2003. 


\section{Reciprocating Engines}

\section{Technology Performance}

\begin{tabular}{|lcc|}
\hline Power Ranges $(\mathrm{kW})$ of Selected Manufacturers & $\underline{\text { High }}$ & Source: Manufacturer Specs \\
Caterpillar & $\underline{\text { Low }}$ & 3,350 \\
Waukesha & 150 & 2,800 \\
Cummins & 200 & 1,750 \\
Jenbacher & 5 & 2,600 \\
Wartsila & 200 & 5,000 \\
\end{tabular}

\section{Market Data}

\begin{tabular}{|c|c|c|c|c|c|}
\hline \multicolumn{2}{|c|}{$\begin{array}{l}\text { Market Shipments } \\
(\mathrm{GW} \text { of units under } 10 \mathrm{MW} \text { in size })\end{array}$} & \multicolumn{4}{|c|}{$\begin{array}{l}\text { Source: Debbie Haught, DOE, communication 2/26/02 - from Diesel and Gas Turbine } \\
\text { Worldwide. }\end{array}$} \\
\hline & 1996 & 1997 & 1998 & 1999 & 2000 \\
\hline Diesel Recips & 7.96 & 7.51 & 8.23 & 10.02 & 16.46 \\
\hline Gas Recips & 0.73 & 1.35 & 1.19 & 1.63 & 2.07 \\
\hline
\end{tabular}




\section{Microturbines}

\section{Technology Description}

Microturbines are small combustion

turbines of a size comparable to a

refrigerator and with outputs of $30 \mathrm{~kW}$ to

$400 \mathrm{~kW}$. They are used for stationary energy generation applications at sites with space limitations for power production.

They are fuel-flexible machines that can run on natural gas, biogas, propane, butane, diesel, and kerosene. Microturbines have few moving parts, high efficiency, low emissions, low electricity costs, and waste heat utilization opportunities; and are lightweight and compact in size. Waste

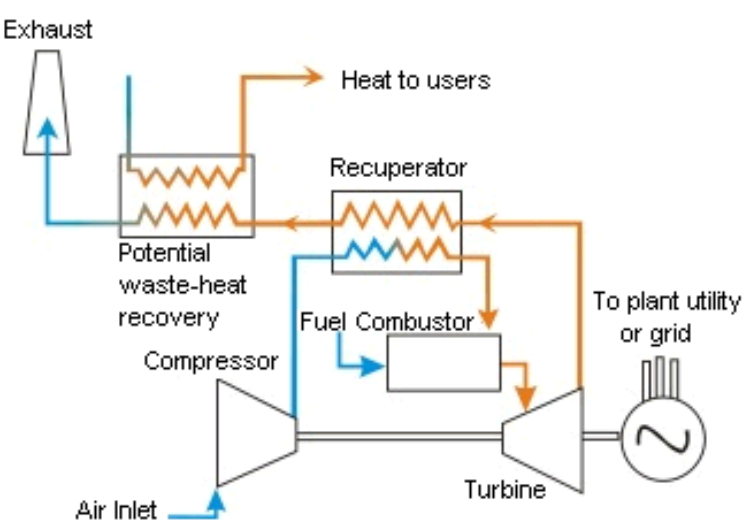
heat recovery can be used in combined heat and power (CHP) systems to achieve energy efficiency levels greater than $80 \%$.

\section{System Concepts}

- Microturbines consist of a compressor, combustor, turbine, alternator, recuperator, and generator.

- Microturbines are classified by the physical arrangement of the component parts: single shaft or two-shaft, simple cycle or recuperated, inter-cooled, and reheat. The machines generally operate at more than 40,000 rpm, while some machines operate at more than 100,000 rpm.

- A single shaft is the more common design, because it is simpler and less expensive to build. Conversely, the split shaft is necessary for machine-drive applications, which do not require an inverter to change the frequency of the AC power.

- Efficiency gains can be achieved with greater use of materials like ceramics, which perform well at higher engine-operating temperatures.

\section{Representative Technologies}

- Microturbines in a simple-cycle, or unrecuperated, turbine; heated, compressed air is mixed with fuel and burned under constant pressure conditions. The resulting hot gas is allowed to expand through a turbine to perform work. Simple-cycle microturbines have a lower cost, higher reliability, and more heat available for CHP applications than recuperated units.

- Recuperated units use a sheet-metal heat exchanger that recovers some of the heat from an exhaust stream and transfers it to the incoming air stream. The preheated air is then used in the combustion process. If the air is preheated, less fuel is necessary to raise its temperature to the required level at the turbine inlet. Recuperated units have a higher efficiency and thermal-to-electric ratio than unrecuperated units, and yield 30\%-40\% fuel savings from preheating.

\section{Technology Applications}

- Microturbines can be used in a wide range of applications in the commercial, industrial, and institutional sectors; microgrid power parks; remote off-grid locations; and premium power markets.

- Microturbines can be used for backup power, baseload power, premium power, remote power, grid support, peak shaving, cooling and heating power, mechanical drive, and use of wastes and biofuels.

- Microturbines can be paired with other distributed energy resources such as energy-storage devices and thermally activated technologies.

\section{Current Status}

- Microturbine systems have recently entered the market, and the manufacturers are targeting both traditional and nontraditional applications in the industrial and buildings sectors, including CHP, backup power, continuous power generation, and peak shaving.

- The most popular microturbine installed to date is the $30-\mathrm{kW}$ system manufactured by Capstone. Microturbine efficiencies are 25-29\% (LHV). 
- The typical $30 \mathrm{~kW}$ unit package cost averages $\$ 1,100 / \mathrm{kW}$. For gas-fired microturbines, the present installation cost (site preparation and natural gas hookup) for a typical $30 \mathrm{~kW}$ commercial unit averages $\$ 2,263 / \mathrm{kW}$ for power only systems and $\$ 2,636$ for CHP systems. Service contracts are available at 1 to 2 cents/kWh

\section{Technology History}

- Microturbines represent a relatively new technology, which entered the commercial market in 1999-2000. The technology used in microturbines is derived from aircraft auxiliary power systems, diesel-engine turbochargers, and automotive designs.

- In 1988, Capstone Turbine Corporation began developing the microturbine concept; and, in 1998, Capstone was the first manufacturer to offer commercial power products using microturbine technology.

\section{Technology Future}

- The acceptable cost target for microturbine energy is $\$ 0.05 / \mathrm{kWh}$, which would present a cost advantage over most nonbaseload utility power.

- "Ultra-clean, high-efficiency" microturbine product designs focus on the following DOE performance targets:

- High Efficiency - Fuel-to-electricity conversion efficiency of at least $40 \%$.

- Environment - NOx $<7$ ppm (natural gas).

- Durability - 1,000 hours of reliable operations between major overhauls and a service life of at least 45,000 hours.

- Cost of Power - System costs $<\$ 500 / \mathrm{kW}$, costs of electricity that are competitive with alternatives (including grid) for market applications by 2005 (for units in the 30-60 kW range)

- Fuel Flexibility - Options for using multiple fuels including diesel, ethanol, landfill gas, and biofuels.

Source: National Renewable Energy Laboratory. Gas-Fired Distributed Energy Resource Technology Characterizations. NREL/TP-620-34783. November 2003. 


\section{Microturbines}

\section{Market Data}

Microturbine Shipments Source: Debbie Haught, communications 2/26/02.

Capstone sales reported in Quarterly SEC filings, others estimated.

No. of units

1998

1999

2000

2001

Capstone

2

211

790

1,033

Other Manufacturers

MW

Capstone

6

23.7

38.1

Other Manufacturers

\section{Technology Performance}

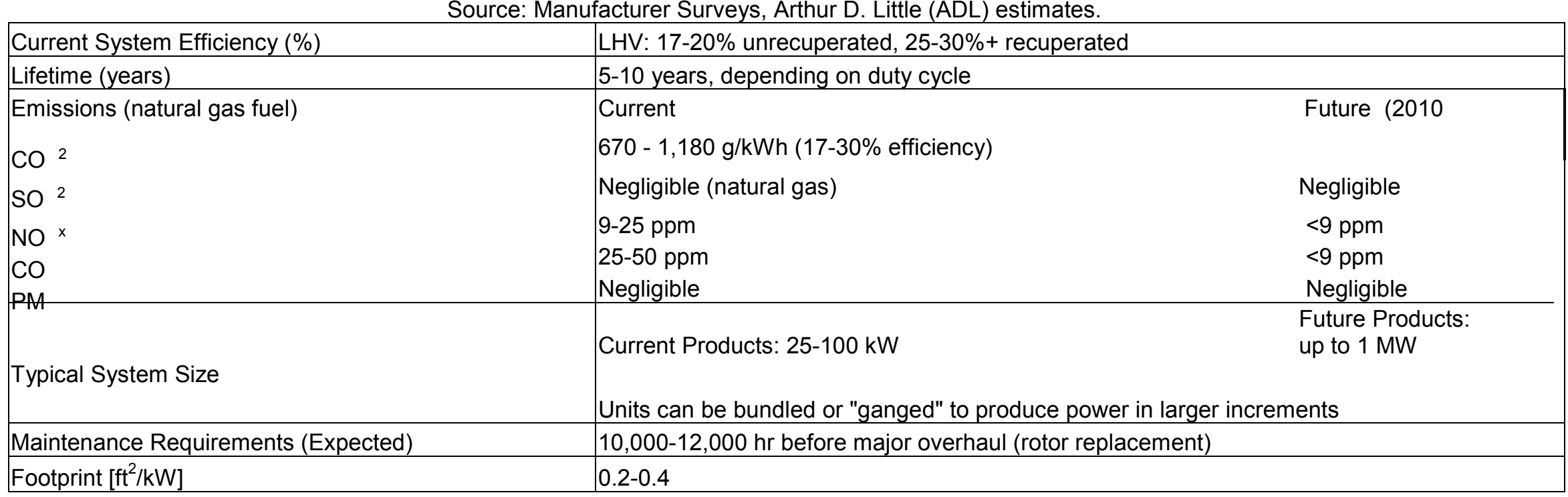




\section{Technology Performance}

Sources: Debbie Haught, DOE, communication 2/26/02 and Energetics Inc. Distributed Energy Technology Simulator: Microturbine Validation, July 122001.

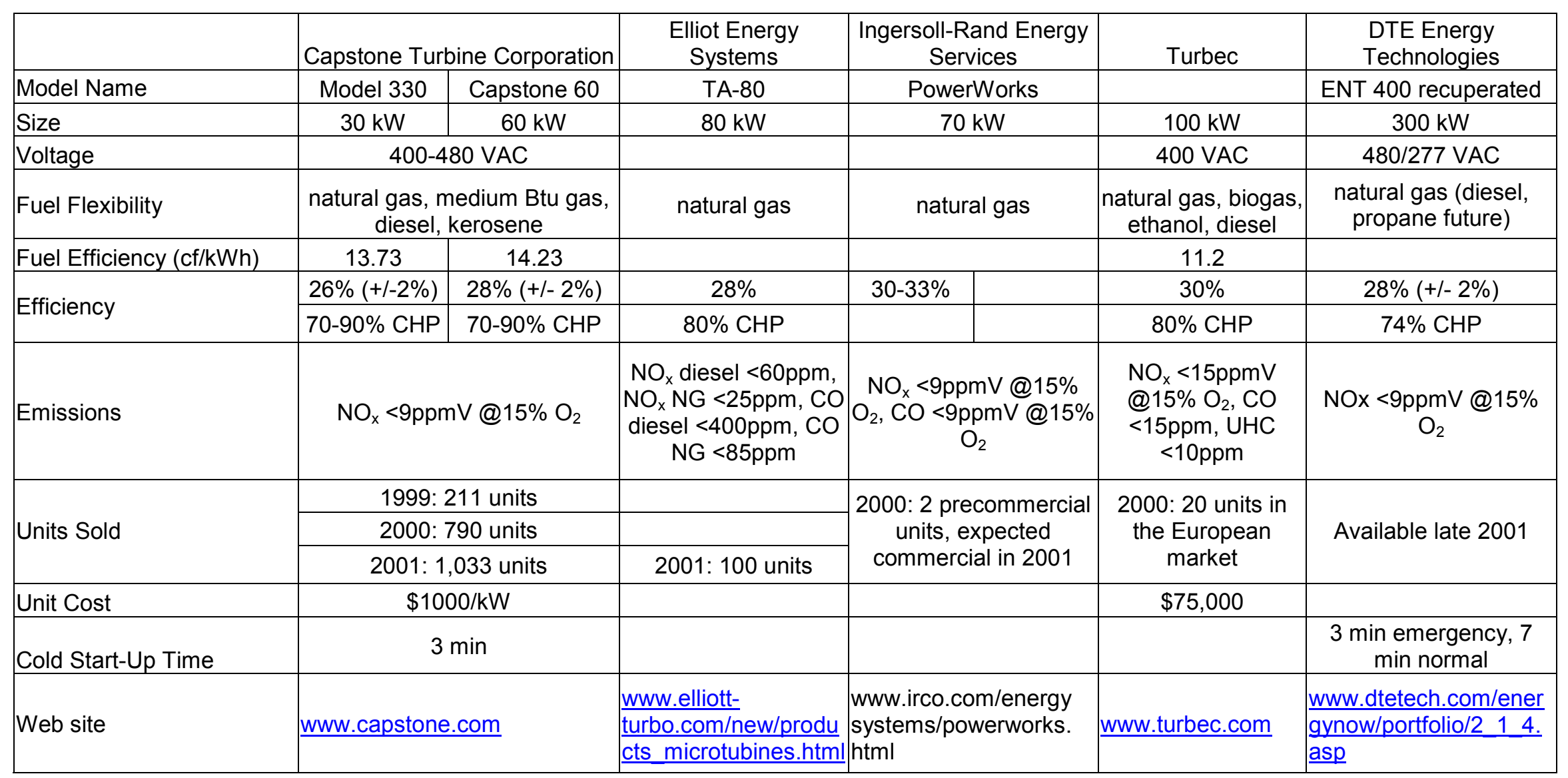




\section{Fuel Cells}

\section{Technology Description}

A fuel cell is an electrochemical energy conversion device that converts hydrogen and oxygen into electricity and water. This unique process is practically silent, nearly eliminates emissions, and has no moving parts.

\section{System Concepts}

- Similar to a battery, fuel cells have an anode and a cathode separated by an electrolyte.

- Hydrogen enters the anode and air (oxygen) enters the cathode. The hydrogen and oxygen are separated into ions and electrons, in the presence of a catalyst. Ions are conducted through the electrolyte while the electrons flow through the anode and the cathode via an external circuit. The current produced can be utilized for electricity. The ions and electrons then recombine, with water and heat as the only byproducts.

- Fuel cell systems today typically consist of a fuel processor, fuel cell stack, and power conditioner. The fuel processor, or reformer, converts hydrocarbon fuels to a mixture of hydrogen-rich gases and, depending on the type of fuel cell, can remove contaminants to provide pure hydrogen. The fuel cell stack is where the hydrogen and oxygen electrochemically combine to produce electricity. The electricity produced is direct current (DC) and the power conditioner converts the DC electricity to alternating current (AC) electricity, for which most of the end-use technologies are designed. As a hydrogen infrastructure emerges, the need for the reformer will disappear as pure hydrogen will be available near point of use.

\section{Representative Technologies}

Fuel cells are categorized by the kind of electrolyte they use:

- Alkaline Fuel Cells (AFCs) were the first type of fuel cell to be used in space applications. AFCs contain a potassium hydroxide $(\mathrm{KOH})$ solution as the electrolyte and operate at temperatures between 60 and $260^{\circ} \mathrm{C}\left(140\right.$ to $\left.500^{\circ} \mathrm{F}\right)$. The fuel supplied to an AFC must be pure hydrogen. Carbon monoxide poisons an AFC, and carbon dioxide (even the small amount in the air) reacts with the electrolyte to form potassium carbonate.

- Phosphoric Acid Fuel Cells (PAFCs) were the first fuel cells to be commercialized. These fuel cells operate at $190-210^{\circ} \mathrm{C}\left(374-410^{\circ} \mathrm{F}\right)$ and achieve 35 to $45 \%$ fuel-to-electricity efficiencies LHV. Commercially-validated reliabilities are $90-95 \%$.

- Proton Exchange Membrane Fuel Cells (PEMFCs) operate at relatively low temperatures of $70-100^{\circ} \mathrm{C}$ $\left(150-180^{\circ} \mathrm{F}\right)$, have high-power density, can vary their output quickly to meet shifts in power demand, and are suited for applications where quick start-up is required (e.g., transportation and power generation). The PEM is a thin fluorinated plastic sheet that allows hydrogen ions (protons) to pass through it. The membrane is coated on both sides with highly dispersed metal alloy particles (mostly platinum) that are active catalysts.

- Molten Carbonate Fuel Cell (MCFC) technology has the potential to reach fuel-to-electricity efficiencies of $45 \%$ to $60 \%$ on a higher heating value basis (HHV). Operating temperatures for MCFCs are around $650^{\circ} \mathrm{C}\left(1,200^{\circ} \mathrm{F}\right)$, which allows total system thermal efficiencies up to $50 \% \mathrm{HHV}$ in combinedcycle applications. MCFCs have been operated on hydrogen, carbon monoxide, natural gas, propane, landfill gas, marine diesel, and simulated coal gasification products.

- Solid Oxide Fuel Cells (SOFCs) operate at temperatures up to $1,000^{\circ} \mathrm{C}\left(1,800^{\circ} \mathrm{F}\right)$, which further enhances combined-cycle performance. A solid oxide system usually uses a hard ceramic material instead 
of a liquid electrolyte. The solid-state ceramic construction enables the high temperatures, allows more flexibility in fuel choice, and contributes to stability and reliability. As with MCFCs, SOFCs are capable of fuel-to-electricity efficiencies of $45 \%$ to $55 \%$ LHV and total system thermal efficiencies up to $85 \%$ LHV in combined-cycle applications.

\section{Technology Applications}

- Fuel cell systems can be sized for grid-connected applications or customer-sited applications in residential, commercial, and industrial facilities. Depending on the type of fuel cell (most likely SOFC and MCFC), useful heat can be captured and used in combined heat and power systems (CHP).

- Premium power applications are an important niche market for fuel cells. Multiple fuel cells can be used to provide extremely high (more then six-nines) reliability and high-quality power for critical loads.

- Data centers and sensitive manufacturing processes are ideal settings for fuel cells.

- Fuel cells also can provide power for vehicles and portable power. PEMFCs are a leading candidate for powering the next generation of vehicles. The military is interested in the high-efficiency, low-noise, small-footprint portable power.

\section{Current Status}

- The cost of fuel cells hinders competition in widespread domestic and international markets without significant subsidies.

- PAFC - More than 250 PAFC systems are in service worldwide, with those installed by ONSI having surpassed 2 million total operating hours with excellent operational characteristics and high availability.

Economic Specifications of the PAFC $(200 \mathrm{~kW})$

\begin{tabular}{|l|l|l|}
\hline Expense & Description & Cost \\
\hline Capital Cost & 1 complete PAFC power plant & $\$ 850,000$ \\
\hline Installation & Electrical, plumbing, and foundation & $\$ 40,000$ \\
\hline Operation & Natural gas costs & $\$ 5.35 / \mathrm{MMcf}$ \\
\hline Minor Maintenance & Service events, semiannual and annual maintenance & $\$ 20,000 / \mathrm{yr}$ \\
\hline Major Overhaul & Replacement of the cell stack & $\$ 320,000 / 5 \mathrm{yrs}$ \\
\hline
\end{tabular}

Source: Energetics, Distributed Energy Technology Simulator: Phosphoric Acid Fuel Cell Validation, May 2001.

- PEMFC - Ballard's first $250 \mathrm{~kW}$ commercial unit is under test. PEM systems up to $200 \mathrm{~kW}$ are also operating in several hydrogen-powered buses. Most units are small $(<10 \mathrm{~kW})$. PEMFCs currently cost several thousand dollars per $\mathrm{kW}$.

- SOFC - A small, $25 \mathrm{~kW}$ natural gas tubular SOFC systems has accumulated more than 70,000 hours of operations, displaying all the essential systems parameters needed to proceed to commercial configurations. Both $5 \mathrm{~kW}$ and $250 \mathrm{~kW}$ models are in demonstration.

- $\mathrm{MCFC}-50 \mathrm{~kW}$ and $2 \mathrm{MW}$ systems have been field-tested. Commercial offerings are in the $250 \mathrm{~kW}-2$ MW range.

\begin{tabular}{|l|l|l|l|l|l|l|}
\hline $\begin{array}{c}\text { Fuel Cell } \\
\text { Type }\end{array}$ & Electrolyte & $\begin{array}{c}\text { Operating } \\
\text { Temp } \\
\left({ }^{\circ} \mathbf{C}\right)\end{array}$ & $\begin{array}{c}\text { Electrical } \\
\text { Efficiency } \\
(\mathbf{\%} \text { HHV) }\end{array}$ & $\begin{array}{c}\text { Commercial } \\
\text { Availability }\end{array}$ & $\begin{array}{c}\text { Typical Unit } \\
\text { Size Range }\end{array}$ & $\begin{array}{c}\text { Start- } \\
\text { up time } \\
\text { (hours) }\end{array}$ \\
\hline AFC & KOH & 260 & $32-40$ & $1960 \mathrm{~s}$ & & \\
\hline PEMFC & Nafion & $65-85$ & $30-40$ & $2000-2001$ & $5-250 \mathrm{~kW}$ & $<0.1$ \\
\hline PAFC & $\begin{array}{l}\text { Phosphoric } \\
\text { Acid }\end{array}$ & $190-210$ & $35-45$ & 1992 & $200 \mathrm{~kW}$ & $1-4$ \\
\hline
\end{tabular}




\begin{tabular}{|l|l|l|l|l|l|l|}
\hline MCFC & $\begin{array}{l}\text { Lithium, } \\
\text { potassium, } \\
\text { carbonate salt }\end{array}$ & $650-700$ & $40-50$ & Post 2003 & $\begin{array}{l}250 \mathrm{~kW}-2 \\
\text { MW }\end{array}$ & $5-10$ \\
\hline SOFC & $\begin{array}{l}\text { Yttrium \& } \\
\text { zirconium } \\
\text { oxides }\end{array}$ & $750-1000$ & $45-55$ & Post 2003 & $5-250 \mathrm{~kW}$ & $5-10$ \\
\hline
\end{tabular}

Sources: Anne Marie Borbely and Jan F. Kreider. Distributed Generation: The Power Paradigm for the New Millennium, CRC Press, 2001, and Arthur D. Little, Distributed Generation Primer: Building the Factual Foundation (multiclient study), February 2000

\section{Technology History}

- In 1839, William Grove, a British jurist and amateur physicist, first discovered the principle of the fuel cell. Grove utilized four large cells, each containing hydrogen and oxygen, to produce electric power which was then used to split the water in the smaller upper cell into hydrogen and oxygen.

- In the 1960s, alkaline fuel cells were developed for space applications that required strict environmental and efficiency performance. The successful demonstration of the fuel cells in space led to their serious consideration for terrestrial applications in the 1970s.

- In the early 1970 s, DuPont introduced the Nafion ${ }^{\circledR}$ membrane, which has traditionally become the electrolyte for PEMFC.

- In 1993, ONSI introduced the first commercially available PAFC. Its collaborative agreement with the U.S. Department of Defense enabled more than 100 PAFCs to be installed and operated at military installations.

- The emergence of new fuel cell types (SOFC, MCFC) in the past decade can lead to technology applications where high temperature heat recovery has value.

\section{Technology Future}

- According to the Business Communications Company, the market for fuel cells was about $\$ 218$ million in 2000 and will reach $\$ 7$ billion by 2009 .

- Fuel cells are being developed for stationary power generation through a partnership of the U.S DOE and the private sector.

- Industry will introduce high-temperature natural gas-fueled MCFC and SOFC at $\$ 1,000-\$ 1,500$ per $\mathrm{kW}$ that are capable of $60 \%$ efficiency, ultra-low emissions, and 40,000 hour stack life.

- DOE is also working with industry to test and validate the PEM technology at the $1-\mathrm{kW}$ level and to transfer technology to the Department of Defense. Other efforts include raising the operating temperature of the PEM fuel cell for building, cooling, heating, and power applications and improve reformer technologies to extract hydrogen from a variety of fuels, including natural gas, propane, and methanol.

Source: National Renewable Energy Laboratory. U.S. Climate Change Technology Program. Technology Options: For the Near and Long Term. DOE/PI-0002. November 2003 (draft update, September 2005); and National Renewable Energy Laboratory. Gas-Fired Distributed Energy Resource Technology Characterizations. NREL/TP-620/34783. November 2003. 


\section{Fuel Cells}

\section{Technology Performance}

\begin{tabular}{|c|c|c|c|c|c|c|c|}
\hline \multirow[b]{3}{*}{ Characteristic } & \multirow[b]{3}{*}{ Units } & \multicolumn{6}{|c|}{$\begin{array}{l}\text { Source: Hydrogen, Fuel Cells \& Infrastructure Technologies Program Multiyear Research, } \\
\text { Development and Demonstration Plan, February } 2005\end{array}$} \\
\hline & & \multicolumn{3}{|c|}{ Small (3-25 kW) } & \multicolumn{3}{|c|}{ Large $(50-250 \mathrm{~kW})$} \\
\hline & & 2004 Status & 2005 & 2010 & 2004 Status & 2005 & 2010 \\
\hline $\begin{array}{l}\text { Electrical Energy Efficiency @ } \\
\text { rated power }\end{array}$ & $\%$ & 30 & 32 & 35 & 30 & 32 & 40 \\
\hline $\begin{array}{l}\text { CHP Energy Efficiency @ } \\
\text { rated power }\end{array}$ & $\%$ & 75 & 75 & 80 & 75 & 75 & 80 \\
\hline Cost & $\$ / \mathrm{kW}$ & & 1500 & 1000 & 2500 & 1500 & 750 \\
\hline $\begin{array}{l}\text { Transient Response Time } \\
\text { (from } 10 \% \text { to } 90 \% \text { power) }\end{array}$ & msec & $<3$ & $<3$ & $<3$ & $<3$ & $<3$ & $<3$ \\
\hline $\begin{array}{l}\text { Cold Start-up Time } \\
\text { (to rated power @ -20 } \\
\text { degrees C ambient) } \\
\text { Continuous-use application }\end{array}$ & 3000 & $<90$ & $<60$ & $<30$ & $<90$ & $<60$ & $<30$ \\
\hline $\begin{array}{l}\text { Survivability (min and max } \\
\text { ambient temperature) }\end{array}$ & C degrees & $\begin{array}{l}-25 \\
+40\end{array}$ & $\begin{array}{l}-30 \\
+40\end{array}$ & $\begin{array}{l}-35 \\
+40\end{array}$ & $\begin{array}{l}-25 \\
+40\end{array}$ & $\begin{array}{l}-30 \\
+40\end{array}$ & $\begin{array}{l}-35 \\
+40\end{array}$ \\
\hline $\begin{array}{l}\text { Durability @ }<10 \% \text { rated } \\
\text { power degradation }\end{array}$ & hour & $>8,000$ & 16,000 & 40,000 & 15,000 & 20,000 & 40,000 \\
\hline
\end{tabular}




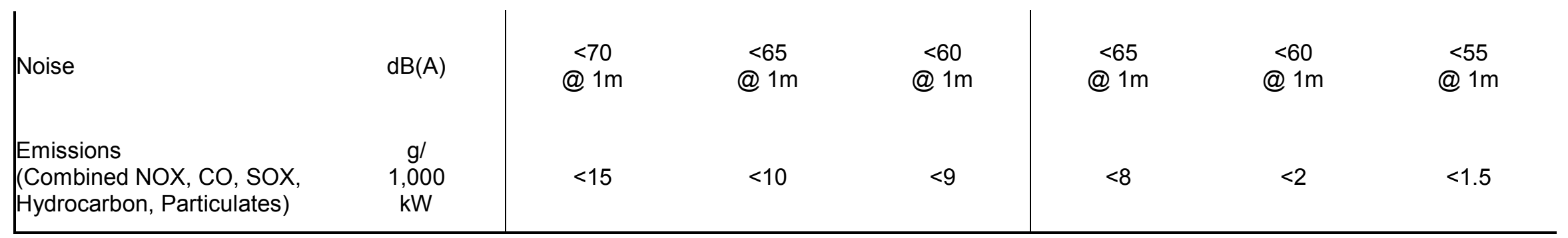

a Includes fuel processor, stack, and all ancillaries.

b Ratio of DC output energy to the LHV of the input fuel (natural gas or LPG) average value at rated power over life of power plant.

c For LPG, efficiencies are 1.5 percentage points lower than natural gas because the reforming process is more complex.

d Ratio of DC output energy plus recovered thermal energy to the LHV of the input fuel (natural gas or LPG) average value at rated power over life of power plant

e Includes projected cost advantage of high-volume production (2,000 units/year). Current cost does not include integrated auxiliaries, battery and power regulator necessary for black start.

$\mathrm{f}$ Not applicable to backup power because this application does not use a fuel processor. 


\section{Batteries}

\section{Technology Description}

Batteries are likely the most widely known type of energy storage. They all store and release electricity through electrochemical processes and come in a variety of shapes and sizes. Some are small enough to fit on a computer circuit board, while others are large enough to power a submarine. Some batteries are used several times a day while others may sit idle for 10 or 20 years before they are ever used. Obviously, for such a diversity of uses, a variety of battery types are necessary. But all of them work from the same basic principles.

System Concepts

Battery electrode plates, typically consisting of chemically reactive materials, are placed in an

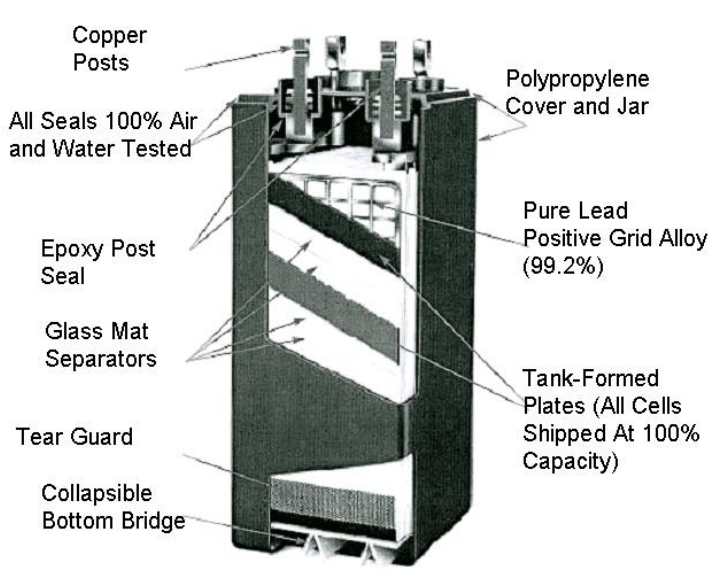
electrolyte, which facilitates the transfer of ions in the battery. The negative electrode gives up electrons during the discharge cycle. This flow of electrons creates electricity that is supplied to any load connected to the battery. The electrons are then transported to the positive electrode. This process is reversed during charging. Batteries store and deliver direct current (DC) electricity. Thus, powerconversion equipment is required to connect a battery to the alternating current (AC) electric grid.

\section{Representative Technologies}

- The most mature battery systems are based on lead-acid technology. There are two major kinds of lead acid batteries: flooded lead acid batteries and valve-regulated-lead-acid (VRLA) batteries.

- There are several rechargeable, advanced batteries under development for stationary and mobile applications, including lithium-ion, lithium polymer, nickel metal hydride, zinc-air, zinc-bromine, sodium sulfur, and sodium bromide.

- These advanced batteries offer potential advantages over lead acid batteries in terms of cost, energy density, footprint, lifetime, operating characteristics, reduced maintenance, and improved performance.

\section{Technology Applications}

- Lead-acid batteries are the most common energy storage technology for stationary and mobile applications. They offer maximum efficiency and reliability for the widest variety of stationary applications: telecommunications, utility switchgear and control, uninterruptible power supplies (UPS), photovoltaic, and nuclear power plants. They provide instantaneous discharge for a few seconds or a few hours.

- Installations can be any size. The largest system to date is $20 \mathrm{MW}$. Lead-acid batteries provide power quality, reliability, peak shaving, spinning reserve, and other ancillary services. The disadvantages of the flooded lead-acid battery include the need for periodic addition of water, and the need for adequate ventilation because the batteries can give off hydrogen gas when charging.

- VRLA batteries are sealed batteries fitted with pressure-release valves. They have been called lowmaintenance batteries, because they do not require periodic adding of water. They can be stacked horizontally as well as vertically, resulting in a smaller footprint than flooded lead-acid batteries. Disadvantages include higher cost and increased sensitivity to the charging cycle used. High temperature results in reduced battery life and performance.

- Several advanced "flow batteries" are being developed. The zinc-bromine battery consists of a zinc positive electrode and a bromine negative electrode separated by a microporous separator. An aqueous solution of zinc/bromide is circulated through the two compartments of the cell from two separate reservoirs. Zinc-bromine batteries are currently being demonstrated in a number of hybrid installations, with microturbines and diesel generators. Sodium bromide/sodium bromine batteries are similar to zinc- 
bromine batteries in function and are under development for large-scale, utility applications. The advantages of flow-battery technologies are low cost, modularity, scalability, transportability, low weight, flexible operation - and all components are easily recyclable. The major disadvantage is a relatively low cycle efficiency.

- Other advanced batteries include the lithium-ion, lithium-polymer, and sodium-sulfur batteries. The advantages of lithium batteries include their high specific energy (four times that of lead-acid batteries) and charge retention. Sodium sulfur batteries operate at high temperature and are being tested for utility load-leveling applications.

\section{Current Status}

- Energy storage systems for large-scale power quality applications ( 10 MW) are economically viable now, with sales from one manufacturer doubling from 2000 to 2001.

- Lead-acid battery annual sales tripled between 1993 and 2000. The relative importance of battery sales for switchgear and UPS applications shrunk during this period from $45 \%$ to $26 \%$ of annual sales by 2000. VRLA and flooded battery sales were \$5.34 million and \$1.71 million, respectively, in 2000 .

- Lead-acid battery manufacturers saw sales drop with the collapse of the telecommunications bubble in 2001. They saw significant growth in sales in 2000, due to the demand from communications firms, and invested in production and marketing in anticipation of further growth.

- Many manufacturers have been subject to mergers and acquisitions. A few dozen manufacturers in the United States and abroad still make batteries.

- Government and private industry are currently developing a variety of advanced batteries for transportation and defense applications: lithium-ion, lithium polymer, nickel metal hydride, sodium metal chloride, sodium sulfur, and zinc bromine.

- Rechargeable lithium batteries already have been introduced in the market for consumer electronics and other portable equipment.

- There are two demonstration sites of ZBB's Zinc Bromine batteries in Michigan and two additional ones in Australia.

- Utility-grade batteries are sized $17-40 \mathrm{MWh}$ and range in efficiency from $70 \%$ to $80 \%$. Such batteries have power densities ranging from 0.2 to $0.4 \mathrm{~kW} / \mathrm{kg}$ and $30-50 \mathrm{Wh} / \mathrm{kg}$ in energy density.

- Batteries are the most common energy storage device.

- About $150 \mathrm{MW}$ of utility peak-shaving batteries were in use in Japan in 2003.

- In 2003, construction began on two 10-MW flow battery systems - one in the U.K. and the other in the United States.

\section{Technology History}

- Most historians date the invention of batteries to about 1800, when experiments by Alessandro Volta resulted in the generation of electrical current from chemical reactions between dissimilar metals.

- Secondary batteries date back to 1860, when Raymond Gaston Planté invented the lead-acid battery. His cell used two thin lead plates separated by rubber sheets. He rolled the combination up and immersed it in a dilute sulfuric acid solution. Initial capacity was extremely limited because the positive plate had little active material available for reaction.

- Others developed batteries using a paste of lead oxides for the positive plate active materials. This allowed much quicker formation and better plate efficiency than the solid Planté plate. Although the rudiments of the flooded lead-acid battery date back to the $1880 \mathrm{~s}$, there has been a continuing stream of improvements in the materials of construction and the manufacturing and formation processes.

- Because many of the problems with flooded lead-acid batteries involved electrolyte leakage, many attempts have been made to eliminate free acid in the battery. German researchers developed the gelledelectrolyte lead-acid battery (a type of VRLA) in the early 1960s. Working from a different approach, Gates Energy Products developed a spiral-wound VRLA cell, which represents the state of the art today. 


\section{Technology Future}

- Lead-acid batteries provide the best long-term power in terms of cycles and float life; and, as a result, will likely remain a strong technology in the future.

- Energy storage and battery systems, in particular, will play a significant role in the Distributed Energy Resource environment of the future. Local energy management and reliability are emerging as important economic incentives for companies.

- The growing market for hybrid vehicles and the potential for "plug-in hybrid" vehicles--that could supply power to the grid as well as draw power from the grid - may increase future demand for batteries. - A contraction in sales of lead-acid batteries that began in 2001 was expected to continue over the next few years until " $9 / 11$ " occurred. Military demand for batteries may drastically alter the forecast for battery sales.

- Battery manufacturers are working on incremental improvements in energy and power density. The battery industry is trying to improve manufacturing practices and build more batteries at lower costs to stay competitive. Gains in development of batteries for mobile applications will likely crossover to the stationary market.

- A $10 \mathrm{MW}-120 \mathrm{MWh}$ sodium bromide system is under construction by the Tennessee Valley Authority. A $40 \mathrm{MW}$ nickel cadmium system is being built for transmission-line support and stabilization in Alaska.

Source: National Renewable Energy Laboratory. U.S. Climate Change Technology Program. Technology Options: For the Near and Long Term. DOE/PI-0002. November 2003 (draft update, September 2005). 


\section{Batteries}

\section{Market Data}

Recent Battery Sales

Source: Battery Council International, Annual Sales Summary, October 2001.

\begin{tabular}{|l|r|r|r|}
\hline & 1993 & $\mathbf{2 0 0 0}$ & Growth \\
\hline Flooded Batteries (Million \$) & 156.9 & 533.5 & $340 \%$ \\
\hline VRLA Batteries (Million \$) & 79.6 & $214 \%$ \\
\hline Total Lead-Acid Batteries (Million \$) & 236.5 & 170.6 & 704.1 \\
\hline
\end{tabular}

\begin{tabular}{|l|r|r|}
\hline Percent Communications & $58 \%$ & $69 \%$ \\
\hline Percent Switchgear/UPS & $45 \%$ & $26 \%$ \\
\hline
\end{tabular}

\section{Market Predictions}

Source: Sandia National Laboratories, Battery Energy

Storage Market Feasibility Study, September 1997.

\begin{tabular}{|c|c|c|}
\hline Year & MW & (\$ Million) \\
\hline 2000 & 496 & 372 \\
\hline 2005 & 805 & 443 \\
\hline 2010 & 965 & 434 \\
\hline
\end{tabular}




\section{Technology Performance}

Grid-Connected Energy Storage

Source: Sandia National Laboratories, Characteristics and Technologies for

Technologies Costs and Efficiencies Long- vs. Short-Term Energy Storage, March 2001.

\begin{tabular}{|c|c|c|c|c|}
\hline Energy-Storage System & $\begin{array}{c}\text { Energy Related } \\
\text { Cost }(\$ / \mathrm{kWh})\end{array}$ & Power Related Cost $(\$ / \mathrm{kW})$ & $\begin{array}{l}\text { Balance of Plant } \\
(\$ / \mathrm{kWh})\end{array}$ & Discharge Efficiency \\
\hline \multicolumn{5}{|l|}{ Lead-acid Batteries } \\
\hline low & 175 & 200 & 50 & 0.85 \\
\hline average & 225 & 250 & 50 & 0.85 \\
\hline high & 250 & 300 & 50 & 0.85 \\
\hline Power-Quality Batteries & 100 & 250 & 40 & 0.85 \\
\hline Advanced Batteries & 245 & 300 & 40 & 0.70 \\
\hline
\end{tabular}

\section{Technology Performance}

Off-Grid Storage Applications, Their Source: Sandia National Laboratories, Energy Storage Systems Program Report for FY99, June 2000.

2010 According to Boeing

\begin{tabular}{|c|c|c|c|c|c|}
\hline Application & $\begin{array}{l}\text { Single Home: } \\
\text { Developing } \\
\text { Community }\end{array}$ & Developing Community: No Industry & $\begin{array}{l}\text { Developing } \\
\text { Community: } \\
\text { Light Industry }\end{array}$ & $\begin{array}{c}\text { Developing } \\
\text { Community: } \\
\text { Moderate Industry }\end{array}$ & $\begin{array}{c}\text { Advanced } \\
\text { Community or } \\
\text { Military Base }\end{array}$ \\
\hline \multicolumn{6}{|l|}{ Storage-System Attributes } \\
\hline Power (kW) & 0.5 & 8 & 40 & 400 & $1 \mathrm{MW}$ \\
\hline Energy (kWh) & 3 & 45 & 240 & 3,600 & 1.5 MWh \\
\hline \multicolumn{6}{|l|}{ Power } \\
\hline Base $(\mathrm{kW})$ & 0.5 & 5 & 10 & 100 & 100 \\
\hline Peak (kW) & & $<8$ & $<40$ & $<400$ & $<1000$ \\
\hline Discharge Duration & 5 to $72 \mathrm{hrs}$ & 5 to $72 \mathrm{hrs}$ & 5 to $24 \mathrm{hrs}$ & 5 to $24 \mathrm{hrs}$ & 0.5 to $1 \mathrm{hr}$ \\
\hline Total Projected Number of Systems & 47 Million & 137,000 & 40,000 & 84,000 & 131,000 \\
\hline Fraction of Market Captured by Storage & $>50$ & $>50$ & $\sim 30$ & $\sim 10$ & $<5$ \\
\hline $\begin{array}{l}\text { Total Number of Storage Systems to } \\
\text { Capture Market Share }\end{array}$ & 24 Million & 69,000 & 12,000 & 8,000 & $<7,000$ \\
\hline
\end{tabular}




\section{Technology Performance}

Advanced Batteries Characteristics

Source: DOE Energy Storage Systems Program Annual Peer Review FY01, Boulder City Battery Energy Storage, November 2001.

\begin{tabular}{|l|c|c|c|}
\hline Energy Storage System & Sodium Sulfur & Vanadium Redox & Zinc Bromine \\
\hline Field Experience & $\begin{array}{c}\text { Over } 30 \\
\text { Projects, } 25 \mathrm{~kW} \\
\text { to } 6 \mathrm{MW}, \\
\text { Largest } 48 \mathrm{MW}\end{array}$ & $\begin{array}{c}\text { Several Projects 100kW to 3 MW (pulse } \\
\text { power), Largest } 1.15 \mathrm{MWh}\end{array}$ & $\begin{array}{c}\text { Several Projects, } \\
50 \mathrm{~kW} \text { to } 250 \mathrm{~kW}, \\
\text { Largest } 400 \mathrm{kWh}\end{array}$ \\
\hline Production Capacity & $160 \mathrm{MWh} / \mathrm{yr}$ & $30 \mathrm{MWh} / \mathrm{yr}$ & 40 to $70 \mathrm{MWh} / \mathrm{yr}$ \\
\hline Actual Production & $50 \mathrm{MWh} / \mathrm{yr}$ & $10 \mathrm{MWh} / \mathrm{yr}$ & $4.5 \mathrm{MWh} / \mathrm{yr}$ \\
\hline Life & $15 \mathrm{yrs}$ & 7 to $15 \mathrm{yrs}$ & 10 to $20 \mathrm{yrs}$ \\
\hline Efficiency & $72 \%$ & $70 \mathrm{to} 80 \%$ & 65 to $70 \%$ \\
\hline O\&M Costs & $\$ 32.5 \mathrm{k} / \mathrm{yr}$ & $\$ 50 \mathrm{k} / \mathrm{yr}$ & $\$ 30$ to $\$ 150 \mathrm{k} / \mathrm{yr}$ \\
\hline
\end{tabular}




\section{Advanced Energy Storage}

\section{Technology Description}

Advanced storage technologies under active development include processes that are mechanical (flywheels, pneumatic), electrochemical (advanced batteries, reversible fuel cells, hydrogen, ultracapacitors), and purely electrical (superconducting magnetic storage). Energy storage devices are added to the utility grid to improve productivity, increase reliability, or defer equipment upgrades. Energy storage devices must be charged and recharged with electricity generated elsewhere. Because the storage efficiency (output compared to input energy) is less than $100 \%$, on a kilowatt-per-kilowatt basis, energy storage does not directly decrease $\mathrm{CO}_{2}$ production. The exception to this rule is the use of advanced energy storage in conjunction with intermittent renewable energy sources (such as photovoltaics and wind) that produce no direct $\mathrm{CO}_{2}$. Energy storage allows these intermittent resources to be dispatchable. Energy-storage devices do positively affect $\mathrm{CO}_{2}$ production on an industrial output basis by providing high-quality power, maximizing industrial productivity. New battery technologies, including sodium sulfur and flow batteries, significantly improve the energy and power densities for stationary battery storage as compared to traditional flooded lead-acid batteries.

\section{System Concepts}

- Stationary applications: Electric demand falls at night, providing an opportunity for the most cost effective electric generators to produce low cost power at night for storage. The stored energy could displace high cost, less efficient power normally produced at the peak during the day. $\mathrm{CO}_{2}$ emissions would be reduced if the efficiency of the energy storage were greater than $85 \%$. Energy storage also can be used to alleviate the pressure on highly loaded components in the grid (transmission lines, transformers, etc.)

These components are typically only loaded heavily for a small portion of the day. The storage system would be placed downstream from the heavily loaded component. This would reduce electrical losses of overloaded systems. Equipment upgrades also would be postponed, allowing the most efficient use of capital by utility companies. For intermittent renewables, advanced energy storage technology would improve their applicability.

- Power quality and reliability: The operation of modern, computerized manufacturing depends directly on the quality of power the plant receives. Any voltage sag or momentary interruption can trip off a manufacturing line and electronic equipment. Industries that are particularly sensitive are semiconductor manufacturing; plastics and paper manufacturing; electronic retailers; and financial services such as banking, stock brokerages, and credit card-processing centers. If an interruption occurs that disrupts these processes, product is often lost, plant cleanup can be required, equipment can be damaged, and transactions can be lost. Any loss must be made up decreasing the overall efficiency of the operation, thereby increasing the amount of $\mathrm{CO}_{2}$ production required for each unit of output. Energy-storage value is usually measured economically with the cost of power-quality losses, which is estimated in excess of $\$ 1.5$ $\mathrm{B} /$ year in the United States alone. Industry is also installing energy-storage systems to purchase relatively cheap off-peak power for use during on-peak times. This use dovetails very nicely with the utilities' interest in minimizing the load on highly loaded sections of the electric grid. Many energy-storage systems offer multiple benefits. This 5-MVA, 3.5-MWh valve-regulated lead-acid battery system is installed at a lead recycling plant in the Los Angeles, California, area. The system provides power-quality protection for the plant's pollution-control equipment, preventing an environmental release in the event of a loss of power. The system carries the critical plant loads while an orderly shutdown occurs. The battery system also in discharged daily during the afternoon peak (and recharged nightly), reducing the plant's energy costs.

\section{Technology Applications}

- For utilities, the most mature storage technology is pumped hydro; however, it requires topography with significant differences in elevation, so it's only practical in certain locations. Compressed-air energy storage uses off-peak electricity to force air into underground caverns or dedicated tanks, and releases the air to drive turbines to generate on-peak electricity; this, too, is location-specific. Batteries, both 
conventional and advanced, are commonly used for energy-storage systems. Advanced flowing electrolyte batteries offer the promise of longer lifetimes and easier scalability to large, multi-MW systems. Superconducting magnetic energy storage (SMES) is largely focused on high-power, shortduration applications such as power quality and transmission system stability. Ultracapacitors have very high power density, but currently have relatively low total energy capacity and are also applicable for high-power, short-duration applications. Flywheels are now commercially viable in power quality and UPS applications, and emerging for high power, high-energy applications.

- Each energy-storage system consists of four major components: the storage device (battery, flywheel, etc.); a power-conversion system; a control system for the storage system, possibly tied in with a utility SCADA (Supervisory Control And Data Acquisition) system or industrial facility control system; and interconnection hardware connecting the storage system to the grid. All common energy-storage devices are DC devices (battery) or produce a varying output (flywheels) requiring a power conversion system to connect it to the $\mathrm{AC}$ grid. The control system must manage the charging and discharging of the system, monitor the state of health of the various components, and interface with the local environment at a minimum to receive on/off signals. Interconnection hardware allows for the safe connection between the storage system and the local grid.

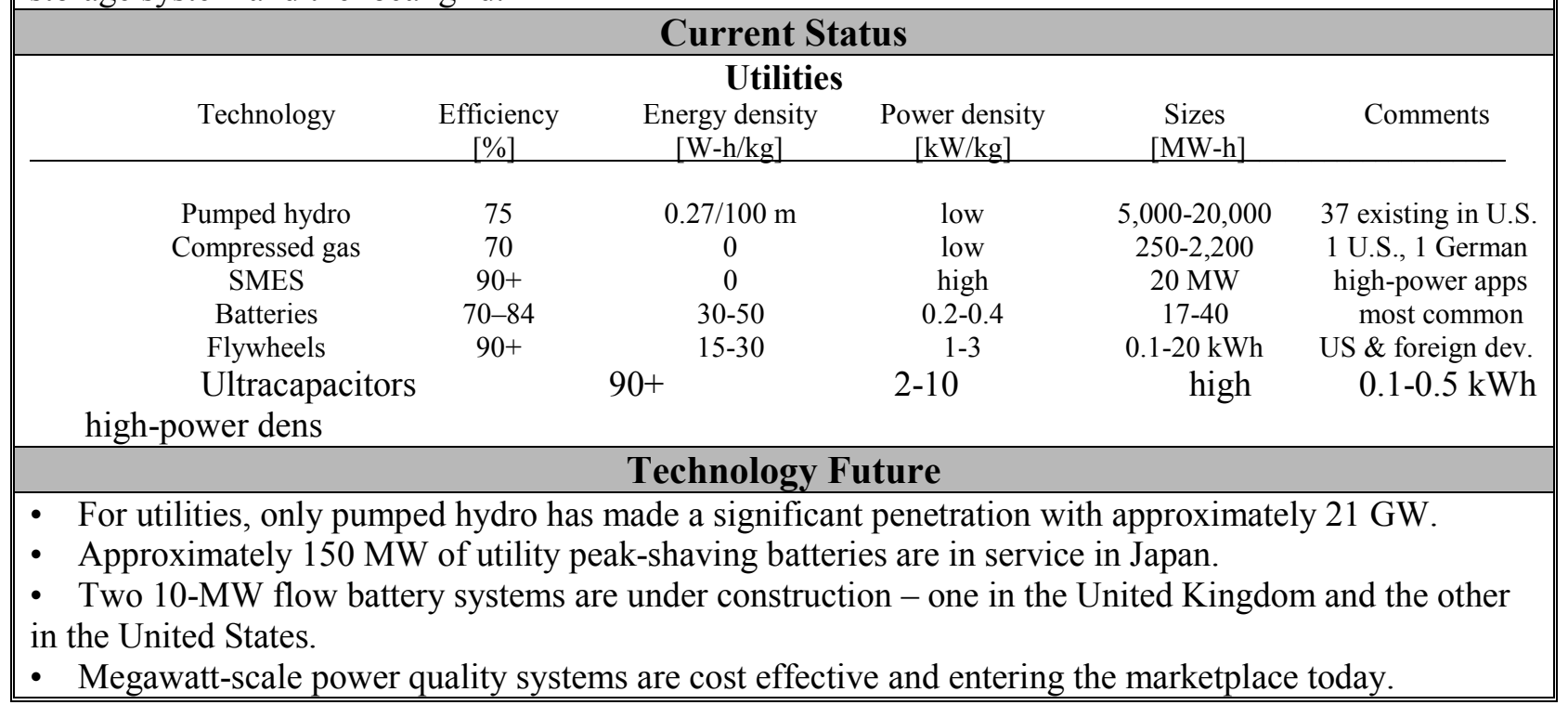

Source: National Renewable Energy Laboratory. U.S. Climate Change Technology Program. Technology Options: For the Near and Long Term. DOE/PI-0002. November 2003 (draft update, September 2005). 


\section{Superconducting Power Technology}

\section{Technology Description}

The United States' ongoing appetite for clean, reliable, and affordable electricity has increased at a rate that seriously threatens to exceed current capacity. Demand is estimated to increase by an average rate of $1.8 \%$ per year for the next 20 years, yet investments in transmission and distribution infrastructure have not kept pace with those in generation. Furthermore, a majority of the new gasfired generation is not optimally sited where existing transmission assets are located. Witnessing the regional outages being experienced throughout the country - and those most recently highlighted in the northeast blackout of August 2003 - the inadequacies of the investment in infrastructure have, in effect, issued a wake-up call for modernizing and expanding grid capacity. High-

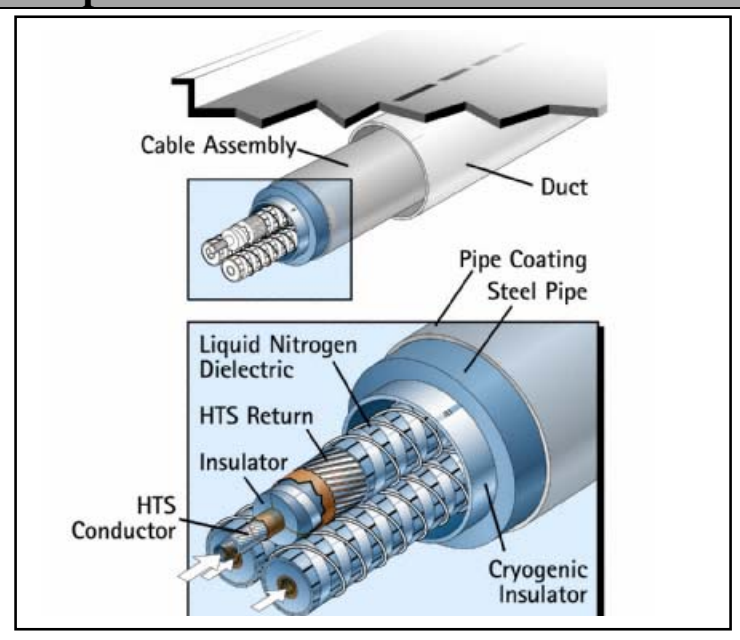

Source: American Superconductor temperature superconducting (HTS) wires can carry many more times the amount of electricity of ordinary aluminum or copper wires. HTS materials were first discovered in the mid-1980s and are brittle oxide, or ceramic-like materials, that can carry electricity with virtually no resistance losses. Through years of federal research in partnership with companies throughout the nation, technology has developed to bond these HTS materials to various metals, providing the flexibility to fashion these ceramics into wires for use in transmission cables and for coils for power transformers, motors, generators, etc. Superconducting technologies make possible electric power equipment that is half the size of conventional alternatives, with half the energy losses. When HTS equipment becomes pervasive, up to $50 \%$ of the energy now lost in transmission and distribution will become available for customer use. HTS also will reduce the impact of power delivery on the environment and is helping create a new high-tech industry to help meet industry challenges due to delays in electric utility restructuring. Other benefits of superconducting electric power systems include improved grid stability, reliability, power quality, and deferred generation expansion. Affordability of capacity expansion is also enhanced, because underground superconducting cables require only $10 \%$ of the rights-of-way of conventional overhead transmission; and because HTS cables may be installed in conventional underground ducts without extensive street excavation.

\section{System Concepts}

- HTS cables have almost no resistance losses and can transport three-five times as much power as a conventional cable in the same size conduit.

- HTS power transformers have about $30 \%$ reduction in total losses, can be $50 \%$ smaller and lighter than conventional units, may have a total ownership cost that is about $20 \%$ lower, are nonflammable, and do not contain oil or any other potential pollutant. In addition, there are electrical performance benefits associated with current limiting capacity and reduced impedance that will yield cost savings to power companies.

- HTS Fault Current Limiters can provide power companies with surge protection within the transmission and distribution system. They are reusable, require minimal maintenance, and do not need replacement after being activated.

- HTS motors rated at more than $750 \mathrm{~kW}$ would save enough energy over their lifetime to pay for the motor. Replacement of all U.S. motors greater than $750-\mathrm{kW}$ with HTS motors would save consumers $\$ 2$ billion per year in electricity costs. The motors are 50\% smaller and lighter than conventional motors, as well. 
- HTS generators with more than 100 MVA output will be more energy efficient, compact, and lighter than the conventional generator. The generator has characteristics that may help stabilize the transmission grid.

\section{System Components}

- HTS cables consist of large numbers of wires containing HTS materials operating at $65-77 \mathrm{~K}$, insulated thermally and electrically from the environment. A cryogenic refrigerating system maintains the temperature of the cable at the desired operating temperature, regardless of the load on the cable.

- HTS transformers use the same types of HTS materials as cables, formed into coils and mounted on conventional transformer cores. Electrical insulation is accomplished by means other than conventional oil-and-paper, and typically involves a combination of solid materials, liquid cryogens, and vacuum. HTS transformers may be overloaded for periods of time without loss of transformer life.

- HTS motors, generators, magnetic separators, and current limiters use HTS wires and tapes in a coil form. Rotating cryogenic seals provide cooling for the rotating machines.

- HTS flywheel systems use nearly frictionless bearings made from superconducting "discs," cooled below the transition temperature of the HTS materials.

\section{Technology Applications}

- HTS wires: First generation "BSCCO" wires are available today in kilometer lengths at about $\$ 200 / \mathrm{kA}-\mathrm{m}$. Prototype, pre-commercial, second-generation "coated conductors" have been made in $100 \mathrm{~m}$ lengths by industry and are to be scaled up in 2006-2008 to 1,000-m lengths. The 100-m tapes carry approximately 100 amperes of current in nitrogen.

- HTS cables: Under the DOE Superconductivity Partnership with Industry (SPI), a team led by Southwire Company has installed and successfully tested a 30-m prototype cable that has been powering three manufacturing plants in Carrollton, Georgia, since February 2000. Three new HTS cable demonstration projects are underway with partial DOE funding from the SPI for 2006. A 600-m cable to be operated at $138-\mathrm{kV}$ will be installed on Long Island, New York; and a 350-m distribution cable is installed in downtown Albany, New York. A section of the 350-m cable will also be manufactured using second-generation "coated conductors." A 200-m HTS distribution cable carrying 3,000 amperes is installed at a suburban substation in Columbus, Ohio.

- HTS transformers: Waukesha Electric Systems, with partial DOE funding, demonstrated a 1-MVA single-phase prototype transformer in 1999 and is leading a team developing technology needed for electrical insulation that would be used for a pre-commercial, three-phase prototype transformer.

- HTS motors: Rockwell Automation successfully demonstrated a prototype 750-kW motor in 2000 and is researching motor components with improved performance characteristics.

\section{Current Status}

- The development at the national laboratories of ion-beam assisted deposition and rolling-assisted, biaxially textured substrate (RABiTS ${ }^{\mathrm{TM}}$ ) technologies for producing high-performance HTS film conductors suitable for cables and transformers, and the involvement of four unique industry-led teams to capitalize on it, was a major success story for FY 1997.

- The world's first HTS cable to power industrial plants exceeded 28,000 hours of trouble-free operation in Carrollton, Georgia, (Southwire Company) in early 2005, and is the world's longestrunning superconducting cable. The 30-m cable system has been operating unattended since June 2001 . Short lengths of coated conductors made under stringent laboratory conditions exceeded the DOE goal of $1,000 \mathrm{~A} / \mathrm{cm}$ width.

- SuperPower verified greater than $80 \%$ current limiting performance of proof-of-concept Fault Current Limiter at up to 8,660 volts.

- Rockwell Automation demonstrated a prototype 1000-HP synchronous motor that exceeded design specifications by $60 \%$, and is now designing a motor that would use second-generation coated conductors with enhanced performance-to-cost ratio for the industrial marketplace. 


\section{Technology History}

- In 1911, after technology allowed liquid helium to be produced, Dutch physicist Heike Kammerlingh Onnes found that at $4.2 \mathrm{~K}$, the electrical resistance of mercury decreased to almost zero. This marked the first discovery of superconducting materials.

- Until 1986, superconductivity applications were highly limited due to the high cost of cooling to such low temperatures, which resulted in costs higher than the benefits of using the new technology. In 1986, two IBM scientists, J. George Bednorz and Karl Müller achieved superconductivity on lanthanum copper oxides doped with barium or strontium at temperatures as high as $38 \mathrm{~K}$.

- In 1987, the compound $\mathrm{Y}_{1} \mathrm{Ba}_{2} \mathrm{Cu}_{3} \mathrm{O}_{7}$ (YBCO) was given considerable attention, as it possessed the highest critical temperature at that time, at $93 \mathrm{~K}$. In the following years, other copper oxide variations were found, such as bismuth lead strontium calcium copper oxide $(110 \mathrm{~K})$, and thallium barium calcium copper oxide (125 K).

- In 1990, the first (dc) HTS motor was demonstrated.

- In 1992, a 1-meter-long HTS cable was demonstrated.

- By 1996, a 200-horsepower HTS motor was tested and exceeded its design goals by $60 \%$.

A Pirelli Cable team installed a 120m HTS cable in Detroit, Michigan under the DOE Superconductivity Partnership Initiative. Since February 2000, Southwire's 30m prototype cable has been powering three manufacturing plants in Carrollton, Georgia.

- HTS transformers have seen increased interest, as Waukesha Electric Systems demonstrated a 1MVA prototype transformer in 1999. This team is also leading the development of a 5/10-MVA, 26.4$\mathrm{kV} / 4.2-\mathrm{kV}$ three-phase prototype.

- A $750 \mathrm{~kW}$ HTS motor was demonstrated by Rockwell Automation. This team is now (in 2006) researching motor components.

\section{Technology Future}

High-temperature superconducting cables and equipment: Commercialization and market introduction requires development of inexpensive wires for transmission and distribution, and end uses such as electric motors. These wires are now under development under a government-industry partnership but are still years from wide-scale use. In addition, there is an international race underway to develop and deploy the new second-generation coated conductors. Numerous companies in Europe, Japan, Korea and China are pursuing the technologies first demonstrated by the national labs. Using hightemperature superconductivity wires to replace existing electric wires and cables may be analogous to the market penetration that occurred when the United States moved from copper wire to fiber optics in communications. Some pre-commercial demonstrations using commercial BSCCO wires are underway, but the Superconductivity Partnerships with Industry and the Second-Generation Wire Initiative could be expanded to include additional U.S. companies. The Power Delivery Research Initiative, authorized in the 2005 Energy Policy Act, would help enable broad utility involvement in the technology.

Source: National Renewable Energy Laboratory. U.S. Climate Change Technology Program. Technology Options: For the Near and Long Term. DOE/PI-0002. November 2003 (draft update, September 2005). 


\section{Superconducting Power Technology}

\section{Market Data}

\begin{tabular}{|c|c|c|c|c|c|c|c|c|c|}
\hline \multirow{2}{*}{$\begin{array}{l}\text { Projected Market for HTS devices } \\
\text { (Thousands of Dollars) }\end{array}$} & \multicolumn{9}{|c|}{$\begin{array}{l}\text { Source: Oak Ridge National Laboratory - High Temperature Superconductivity: The Products and } \\
\text { Their Benefits, } 2002 \text { Edition, Total Market Benefits, p } 40 .\end{array}$} \\
\hline & 2004 & 2006 & 2008 & 2010 & 2012 & 2014 & 2016 & 2018 & 2020 \\
\hline Motors & 0 & 0 & 27.29 & 169.24 & 527.03 & 1310.49 & 3103.37 & 6360.31 & 11322.83 \\
\hline Transformers & 0 & 3.8 & 14.22 & 37.47 & 90.63 & 197.73 & 371.87 & 605.23 & 877.71 \\
\hline Generators & 0 & 0 & 0 & 4.09 & 15.56 & 41.12 & 101.16 & 224.26 & 426.61 \\
\hline Cables & 0 & 0.17 & 0.59 & 1.44 & 2.81 & 4.86 & 7.7 & 11.21 & 15.17 \\
\hline Total & 0 & 3.97 & 42.1 & 212.24 & 636.03 & 1554.2 & 3584.1 & 7201.01 & 12642.32 \\
\hline
\end{tabular}

The report assumes electrical generation and equipment market growth averaging $2.5 \%$ per year through 2020 . This number was chosen based on historic figures (the past fifteen years) and the assumption that electric demand will drive electric supply.

\begin{tabular}{|c|c|c|c|c|c|c|c|c|}
\hline \multirow{2}{*}{$\begin{array}{l}\text { Projected Market for HTS devices } \\
\text { (Thousands of Dollars) }\end{array}$} & \multicolumn{8}{|c|}{$\begin{array}{l}\text { Source: Analysis of Future Prices and Markets for High-Temperature Superconductors, September } \\
\text { 2001, DOE. }\end{array}$} \\
\hline & 2011 & 2013 & 2015 & 2017 & 2019 & 2021 & 2023 & 2025 \\
\hline Motors & 225 & 956 & 4,025 & 15,399 & 50,968 & 108,429 & 148,770 & 164,072 \\
\hline Transformers & 0 & 0 & 243 & 1,451 & 9,353 & 56,081 & 222,277 & 390,964 \\
\hline Generators & 6,926 & 24,710 & 83,634 & 227,535 & 445,693 & 592,904 & 656,499 & 675,656 \\
\hline Cables & 4,117 & 14,405 & 48,335 & 135,001 & 318,844 & 488,783 & 570,326 & 586,284 \\
\hline Total & 11,270 & 40,071 & 136,236 & 379,386 & 824,857 & $1,246,196$ & $1,597,872$ & $1,816,975$ \\
\hline
\end{tabular}




\section{Technology Performance}

\begin{tabular}{|c|c|c|c|c|c|c|c|c|c|}
\hline \multirow{2}{*}{$\begin{array}{l}\text { HTS Energy Savings } \\
\text { (GWh) }\end{array}$} & \multicolumn{9}{|c|}{$\begin{array}{l}\text { Source: Oak Ridge National Laboratory - High-Temperature Superconductivity: The Products and } \\
\text { Their Benefits, } 2002 \text { Edition, Tables M-2, T-1, G-1, C-2 }\end{array}$} \\
\hline & 2004 & 2006 & 2008 & 2010 & 2012 & 2014 & 2016 & 2018 & 2020 \\
\hline Motors & 0 & 0 & 0.4 & 3 & 8 & 21 & 48 & 98 & 172 \\
\hline Transformers & 0 & 0.1 & 0.2 & 1 & 1 & 3 & 6 & 9 & 14 \\
\hline Total & 0 & 4 & 19 & 60 & 143 & 294 & 544 & 916 & 1,428 \\
\hline \multirow{2}{*}{$\begin{array}{l}\text { HTS Energy Savings } \\
\text { (GWh) }\end{array}$} & \multicolumn{9}{|c|}{$\begin{array}{l}\text { Source: Analysis of Future Prices and Markets for High-Temperature Superconductors, September } \\
\text { 2001, DOE. }\end{array}$} \\
\hline & 2009 & 2011 & 2013 & 2015 & 2017 & 2019 & 2021 & 2023 & 2025 \\
\hline Generators & 2 & 11 & 44 & 171 & 556 & 1,417 & 2,699 & 4,196 & 5,785 \\
\hline Cables & 1 & 3 & 13 & 55 & 196 & 598 & 1,336 & 2,289 & 3,326 \\
\hline Total & 3 & 14 & 58 & 231 & 769 & 2,086 & 4,283 & 7,235 & 10,774 \\
\hline
\end{tabular}




\section{Thermally Activated Technologies}

\section{Technology Description}

Thermally Activated Technologies (TATs), such as heat pumps, absorption chillers, and desiccant units, provide on-site space conditioning and water heating, which greatly reduce the electric load of a residential or commercial facility. These technologies can greatly contribute to system reliability.

\section{System Concepts}

- TATs may be powered by natural gas, fuel oil, propane, or biogas, avoiding substantial energy conversion losses associated with electric power transmission, distribution, and generation.

- These technologies may use the waste heat from onsite power generation and provide total energy solutions for onsite cooling, heating, and power.

\section{Representative Technologies}

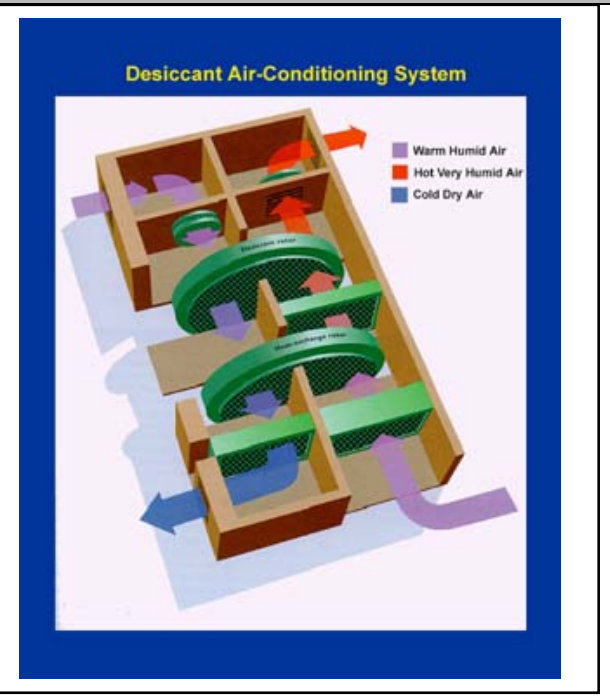

- Thermally activated heat pumps can revolutionize the way residential and commercial buildings are heated and cooled. This technology enables highly efficient heat pump cycles to replace the best natural gas furnaces, reducing energy use as much as $50 \%$. Heat pumps take in heat at a lower temperature and release it a higher one, with a reversing valve that allows the heat pump to provide space heating or cooling as necessary. In the heating mode, heat is taken from outside air when the refrigerant evaporates and is delivered to the building interior when it condenses. In the cooling mode, the function of the two heat-exchanger coils is reversed, so heat moves inside to outside.

- Absorption chillers provide cooling to buildings by using heat. Unlike conventional electric chillers, which use mechanical energy in a vapor-compression process to provide refrigeration, absorption chillers primarily use heat energy with limited mechanical energy for pumping. The chiller transfers thermal energy from the heat source to the heat sink through an absorbent fluid and a refrigerant. The chiller achieves its refrigerative effect by absorbing and then releasing water vapor into and out of a lithium bromide solution. In the process, heat is applied at the generator and water vapor is driven off to a condenser. The cooled water vapor then passes through an expansion valve, reducing the pressure. The low-pressure water vapor then enters an evaporator, where ambient heat is added from a load and the actual cooling takes place. The heated, low-pressure vapor returns to the absorber, where it recombines with lithium bromide and becomes a low-pressure liquid. This low-pressure solution is pumped to a higher pressure and into the generator to repeat the process.

- Desiccant equipment is useful for mitigation of indoor air-quality problems and for improved humidity control in buildings. The desiccant is usually formed in a wheel made up of lightweight honeycomb or corrugated material (see figure). Commercially available desiccants include silica gel, activated alumina, natural and synthetic zeolites, lithium chloride, and synthetic polymers. The wheel is rotated through supply air, usually from the outside, and the material naturally attracts the moisture from the air before it is routed to the building. The desiccant is then regenerated using thermal energy from natural gas, the sun, or waste heat.

\section{Technology Applications}

- Thermally activated heat pumps are a new generation of advanced absorption cycle heat pumps that can efficiently condition residential and commercial space. Different heat pumps will be best suited for different applications. For example, the GAX heat pump is targeted for northern states because of its superior heating performance; and the Hi-Cool heat pump targets the South, where cooling is a priority.

- Absorption chillers can change a building's thermal and electric profile by shifting the cooling from an electric load to a thermal load. This shift can be very important for facilities with time-of-day 
electrical rates, high cooling-season rates, and high demand charges. Facilities with high thermal loads, such as data centers, grocery stores, and casinos, are promising markets for absorption chillers.

- Desiccant technology can either supplement a conventional air-conditioning system or act as a standalone operation. A desiccant can remove moisture, odors, and pollutants for a healthier and more comfortable indoor environment. Facilities with stringent indoor air-quality needs (schools, hospitals, grocery stores, hotels) have adapted desiccant technology.

- CHP applications are well suited for TATs. They offer a source of "free" fuel in the form of waste heat that can power heat pumps and absorption chillers, and regenerate desiccant units.

\section{Current Status}

- Thermally activated heat pump technology can replace the best natural gas furnace and reduce energy use by as much as $50 \%$, while also providing gas-fired technology.

- Desiccant technology may be used in pharmaceutical manufacturing to extend the shelf life of products; refrigerated warehouses to prevent water vapor from forming on the walls, floors, and ceilings; operating rooms to remove moisture form the air, keeping duct work and sterile surfaces dry; and hotels, to prevent buildup of mold and mildew.

\section{Technology History}

- In the 1930s, the concept of dehumidifying air by scrubbing it with lithium chloride was introduced, paving the way for development of the first desiccant unit.

- In 1970, Trane introduced a mass-produced, steam-fired, double-effect $\mathrm{LiBr} / \mathrm{H} 2 \mathrm{O}$ absorption chiller.

- In 1987, the National Appliance Energy Conversion Act instituted minimum efficiency standards for central air-conditioners and heat pumps.

\section{Technology Future}

- Expand the residential market of the second-generation Hi-Cool residential absorption heat pump technology to include markets in southern states; the targeted $30 \%$ improvement in cooling performance can only be achieved with major new advancements in absorption technology or with an engine-driven system.

- Work in parallel with the first-generation GAX effort to determine the most attractive secondgeneration Hi-Cool technology.

- Fabricate and test the 8-ton advanced cycle VX GAX ammonia/water heat pump.

- Fabricate and test the 3-ton complex compound heat pump and chiller.

- Develop, test, and market an advanced Double Condenser Coupled commercial chiller, which is expected to be $50 \%$ more efficient than conventional chillers.

- Assess new equipment designs and concepts for desiccants using diagnostic techniques, such as infrared thermal performance mapping and advanced tracer gas-leak detection. 


\section{1 - States with Competitive Electricity Markets}

Purple-colored states (Figure 3.1.1) are active in the restructuring process, and these states have either enacted enabling legislation or issued a regulatory order to implement retail access. Retail access is either currently available to all or some customers. Those states are Arizona, Connecticut, Delaware, District of Columbia, Illinois, Maine, Maryland, Massachusetts, Michigan, New Hampshire, New Jersey, New York, Ohio, Oregon, Pennsylvania, Rhode Island, Texas, and Virginia. In Oregon, the law allows nonresidential customers retail access.

A green-colored state signifies a delay in the restructuring process or the implementation of retail access. Those states are Arkansas, Montana, Nevada, New Mexico, and Oklahoma.

California is the only blue-colored state, because direct retail access has been suspended.

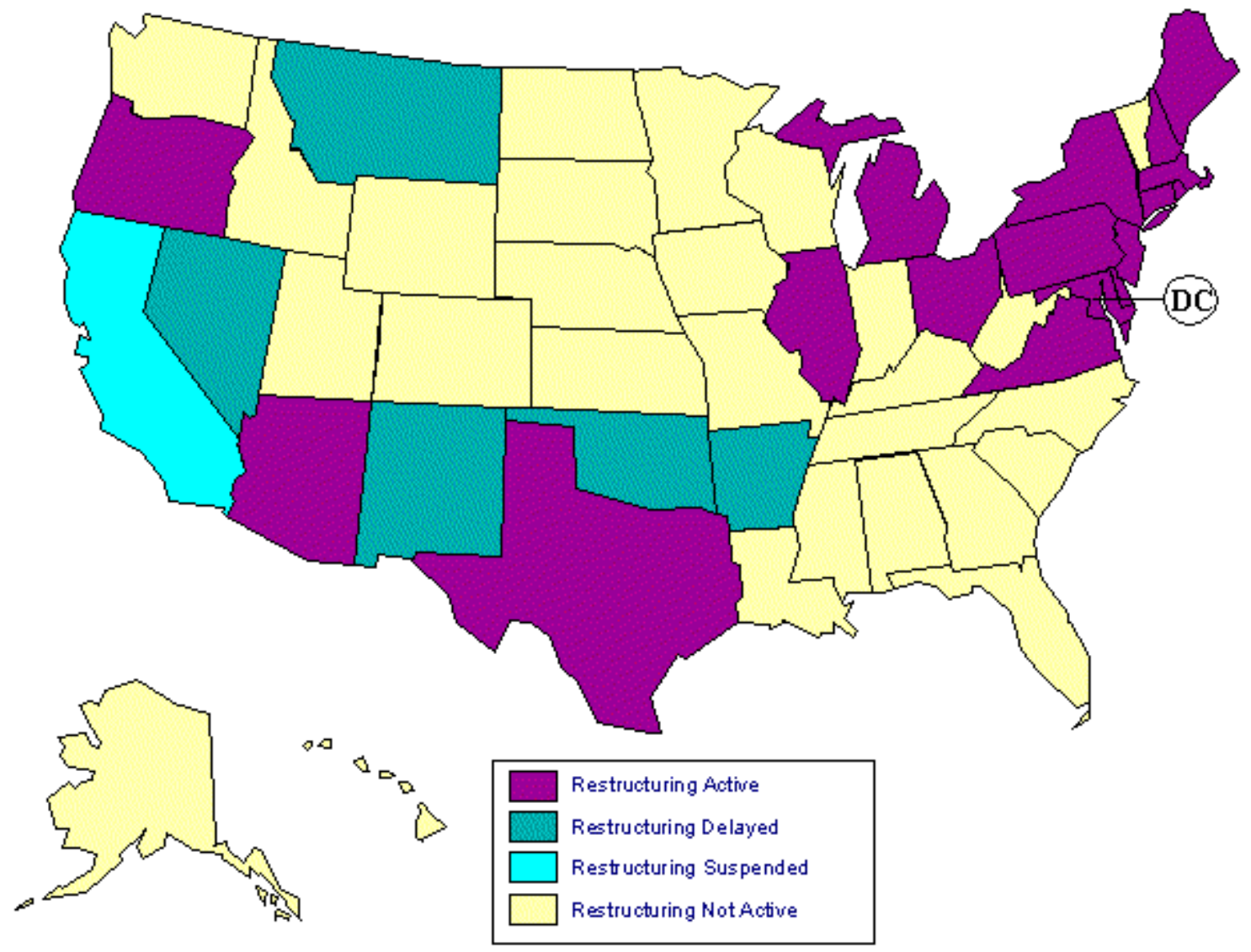

Source: U.S. DOE, Energy Information Administration, last updated February 2003.

Figure 3.1.1: Status of Restructuring of State Electricity Markets 


\section{2 - States with System Benefit Charges (SBC)}

A System Benefit Charge (SBC) is a small fee added to a customer's electricity bill used to fund programs that benefit the public, such as low-income energy assistance, energy efficiency, and renewable energy. There are 15 states with SBCs (Table 3.2.1) through which a portion of the money will be used to support renewable resources. Together, these states will collect about $\$ 4$ billion (Figure 3.2.1) in funds to support renewable resources between 1998 and 2017.

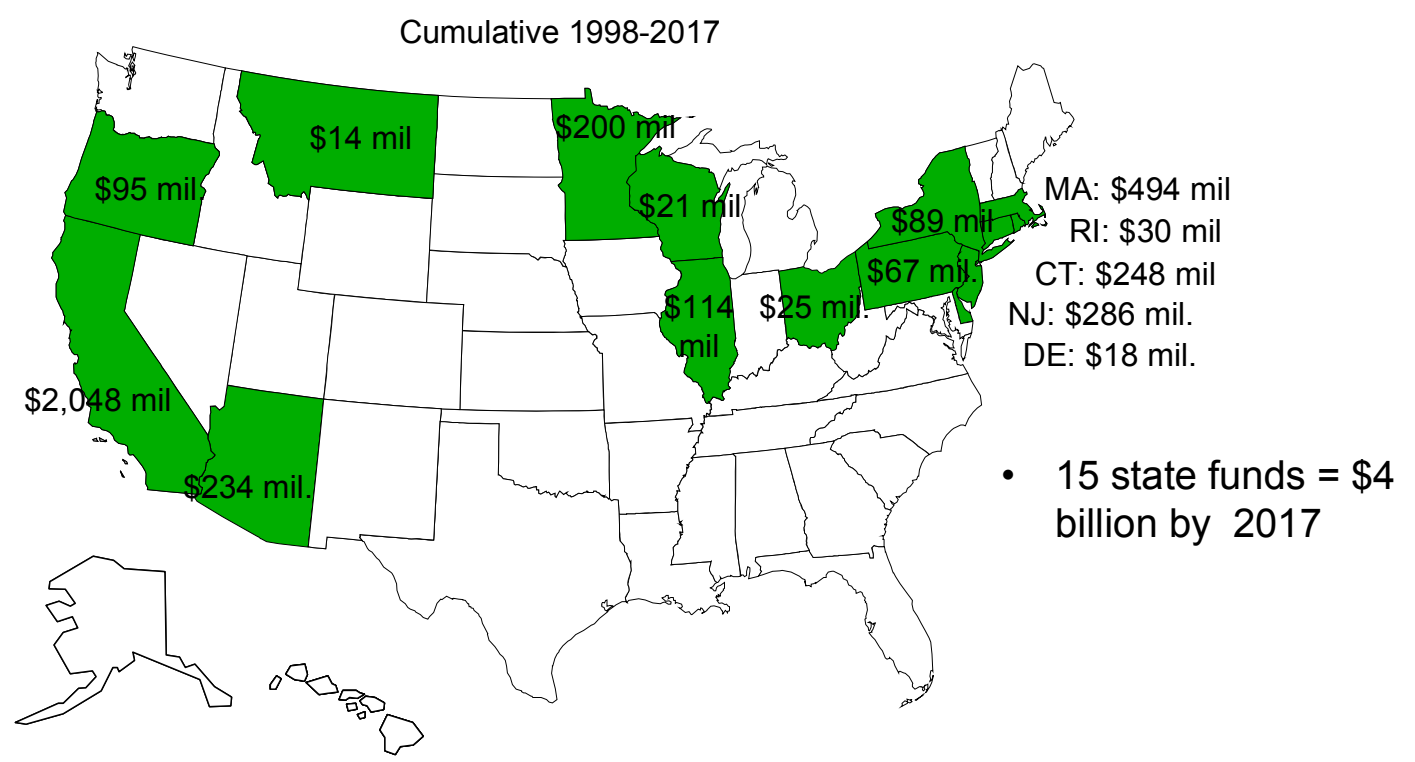

Source: Union of Concerned Scientists, June 2004

http://www.ucsusa.org/clean_energy/clean_energy_policies/state-clean-energy-maps-and-graphs.html

Figure 3.2.1: State System Benefit Funds 


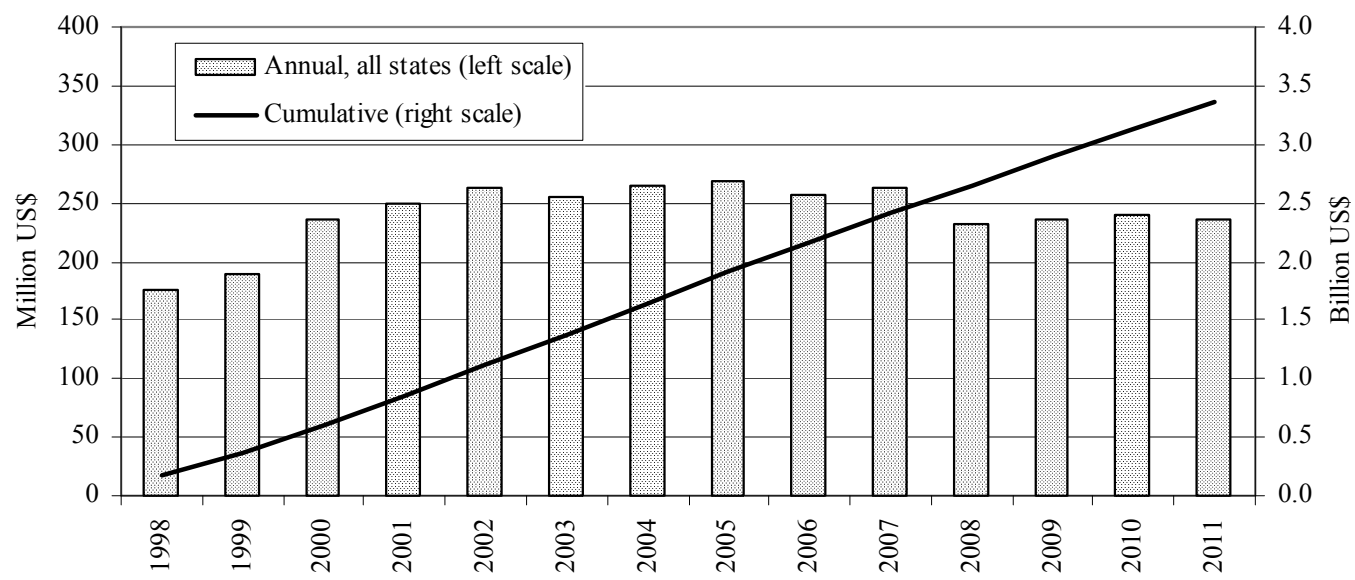

Source: Bolinger, M., R. Wiser, L. Milford, M. Stoddard, and K. Porter. Clean Energy Funds: An Overview of State Support for Renewable Energy, Lawrence Berkeley National Laboratory, April 2001.

Figure 3.2.2: Aggregation Annual and Cumulative State Funding

Table 3.2.1: Renewable Energy Funding Levels and Program Duration

\begin{tabular}{|l|l|l|l|l|}
\hline State & \multicolumn{1}{|c|}{$\begin{array}{c}\text { Approximate Annual } \\
\text { Funding } \\
\text { (\$ Million) }\end{array}$} & $\begin{array}{c}\text { \$ Per-Capita } \\
\text { Annual } \\
\text { Funding }\end{array}$ & $\begin{array}{c}\text { \$ Per-MWh } \\
\text { Funding }\end{array}$ & Funding Duration \\
\hline CA & 135 & 4.0 & 0.58 & $1998-2012$ \\
\hline CT & $15 \rightarrow 30$ & 4.4 & 0.50 & $2000-$ indefinite \\
\hline DE & 1 (maximum) & 1.3 & 0.09 & $10 / 1999-$ indefinite \\
\hline IL & 5 & 0.4 & 0.04 & $1998-2007$ \\
\hline MA & $30 \rightarrow 20$ & 4.7 & 0.59 & $1998-$ indefinite \\
\hline MN & 9 & N/A & N/A & $2000-$ indefinite \\
\hline MT & 2 & 2.2 & 0.20 & $1999-7 / 2003$ \\
\hline NJ & 30 & 3.6 & 0.43 & $2001-2008$ \\
\hline NM & 4 & 2.2 & 0.22 & $2007-$ indefinite \\
\hline NY & $6 \rightarrow 14$ & 0.7 & 0.11 & $7 / 1998-6 / 2006$ \\
\hline OH & $15 \rightarrow 5$ (portion of) & 1.3 & 0.09 & $2001-2010$ \\
\hline OR & 8.6 & 2.5 & 0.17 & $10 / 2001-9 / 2010$ \\
\hline PA & 10.8 (portion of) & 0.9 & 0.08 & $1999-$ indefinite \\
\hline RI & 2 & 1.9 & 0.28 & $1997-2003$ \\
\hline WI & $1 \rightarrow 4.8$ & 0.9 & 0.07 & $4 / 1999-$ indefinite \\
\hline NI & Ann & & \\
\hline
\end{tabular}

Note: Annual and per-MWh funding are based on funds expected in 2001.

Source: Bolinger et al., 2001

SBC funding, so far, has supported the development of $707 \mathrm{MW}$ of generating capacity that is online. A further 1,548 MW of new capacity is still pending for a total of 163 different projects. Nationwide, there is currently about $\$ 345$ million in funding obligated through the respective SBC programs (Table 3.2.2). 
Table 3.2.2: State SBC Funding for Utility-Scale Renewable Projects (as of September 2004)

\begin{tabular}{|l|r|r|r|r|r|r|r|}
\hline $\begin{array}{c}\text { Project } \\
\text { Location }\end{array}$ & $\begin{array}{c}\text { \# of } \\
\text { Projects }\end{array}$ & \multicolumn{1}{|c|}{$\begin{array}{c}\text { Original } \\
\text { Dollars } \\
\text { Obligated (\$) }\end{array}$} & $\begin{array}{c}\text { Current } \\
\text { Dollars } \\
\text { Obligated (\$) }\end{array}$ & $\begin{array}{c}\text { Capacity } \\
\text { Obligated } \\
\text { (MW) }\end{array}$ & $\begin{array}{c}\text { Capacity } \\
\text { Cancelled } \\
\text { (MW) }\end{array}$ & $\begin{array}{c}\text { Capacity } \\
\text { Pending } \\
\text { (MW) }\end{array}$ & $\begin{array}{c}\text { Capacity } \\
\text { On-Line } \\
\text { (MW) }\end{array}$ \\
\hline CA & 60 & $\$ 243,573,376$ & $\$ 193,019,993$ & $1,285.3$ & 30.6 & 830.1 & 424.5 \\
\hline IL & 4 & $\$ 9,305,000$ & $\$ 9,305,000$ & 101.6 & 0.0 & 51.2 & 50.4 \\
\hline MA & 4 & $\$ 19,469,093$ & $\$ 19,469,093$ & 49.6 & 0.0 & 49.6 & 0.0 \\
\hline MN & 68 & $\$ 61,841,977$ & $\$ 61,841,977$ & 124.9 & 1.7 & 91.7 & 31.5 \\
\hline NH $^{*}$ & 1 & $\$ 2,378,930$ & $\$ 2,378,930$ & 50.0 & 0.0 & 50.0 & 0.0 \\
\hline NJ & 5 & $\$ 14,590,000$ & $\$ 14,590,000$ & 41.1 & 0.0 & 41.4 & 0.0 \\
\hline NY & 12 & $\$ 26,560,000$ & $\$ 26,560,000$ & 325.2 & 0.0 & 283.6 & 41.6 \\
\hline OR & 1 & $\$ 3,800,000$ & $\$ 3,800,000$ & 41.0 & 0.0 & 0.0 & 41.0 \\
\hline PA & 8 & $\$ 17,600,000$ & $\$ 14,000,000$ & 269.6 & 0.0 & 151.1 & 118.5 \\
\hline Total & 163 & $\$ 399,118,376$ & $\$ 344,964,993$ & $2,288.1$ & 32.3 & $1,548.4$ & 707.4 \\
\hline
\end{tabular}

${ }^{*}$ New Hampshire does not currently have a clean energy fund. The single project located in New Hampshire is receiving support from Massachusetts' clean energy fund.

Source: Bolinger, M., R. Wiser, and G. Fitzgerald, 2004. The Impact of State Clean Energy Fund Support for Utility-Scale Renewable Energy Projects. Prepared by Lawrence Berkeley National Laboratory and the Clean Energy States Alliance, October. http://www.cleanenergystates.org/CaseStudies/LBNL-

56422_Utility-Scale_Renewables.pdf

Of the 163 projects announced, the vast majority - both in terms of number of projects and generating capacity - are wind power projects (Table 3.2.3). In descending order of capacity are geothermal, landfill gas, biomass, hydropower, waste tire, and digester gas.

\section{Table 3.2.3: Support for Utility-Scale Renewable Projects by Resource Type} (as of September 2004)

\begin{tabular}{|l|r|r|r|r|r|r|r|}
\hline $\begin{array}{c}\text { Resource } \\
\text { Type }\end{array}$ & $\begin{array}{c}\text { \# of } \\
\text { Projects }\end{array}$ & \multicolumn{1}{|c|}{$\begin{array}{c}\text { Original } \\
\text { Dollars } \\
\text { Obligated (\$) }\end{array}$} & $\begin{array}{c}\text { Current } \\
\text { Dollars } \\
\text { Obligated (\$) }\end{array}$ & $\begin{array}{c}\text { Capacity } \\
\text { Obligated } \\
\text { (MW) }\end{array}$ & $\begin{array}{c}\text { Capacity } \\
\text { Cancelled } \\
\text { (MW) }\end{array}$ & $\begin{array}{c}\text { Capacity } \\
\text { Pending } \\
\text { (MW) }\end{array}$ & $\begin{array}{c}\text { Capacity } \\
\text { On-Line } \\
\text { (MW) }\end{array}$ \\
\hline Biomass & 8 & $\$ 15,406,770$ & $\$ 11,466,832$ & 85.2 & 9.5 & 64.4 & 11.3 \\
\hline $\begin{array}{l}\text { Digester } \\
\text { Gas }\end{array}$ & 3 & $\$ 4,108,210$ & $\$ 4,108,210$ & 6.0 & 0.0 & 3.9 & 2.1 \\
\hline Geothermal & 4 & $\$ 80,331,618$ & $\$ 80,331,618$ & 156.9 & 0.0 & 97.9 & 59.0 \\
\hline Hydro & 7 & $\$ 12,977,258$ & $\$ 11,787,988$ & 45.7 & 0.0 & 14.5 & 31.3 \\
\hline Landfill Gas & 28 & $\$ 38,108,552$ & $\$ 31,098,469$ & 90.7 & 19.8 & 35.1 & 35.8 \\
\hline Waste Tire & 1 & $\$ 7,232,413$ & $\$ 3,287,461$ & 30.0 & 0.0 & 30.0 & 0.0 \\
\hline Wind & 112 & $\$ 240,953,555$ & $\$ 202,884,417$ & $1,873.60$ & 3.0 & $1,302.6$ & 568.0 \\
\hline Total & 163 & $\$ 399,118,376$ & $\$ 344,964,993$ & $2,288.1$ & 32.3 & $1,548.4$ & 707.4 \\
\hline
\end{tabular}

Source: Bolinger, M., R. Wiser, and G. Fitzgerald, 2004. The Impact of State Clean Energy Fund Support for Utility-Scale Renewable Energy Projects. Prepared by Lawrence Berkeley National Laboratory and the Clean Energy States Alliance, October. http://www.cleanenergystates.org/CaseStudies/LBNL56422_Utility-Scale_Renewables.pdf 


\section{3 - States with Renewable Portfolio Standards (RPS)}

A Renewable Portfolio Standard (RPS) is a policy that obligates a retail electricity supplier to include renewable resources in its electricity-generation portfolio. Retail suppliers can meet the obligation by constructing or owning eligible renewable resources or purchasing the power from eligible generators. To date, 20 states plus Washington, D.C., have adopted RPS policies (Table 3.3.1) or renewable purchase obligations (Figure 3.3.1), while several other states have adopted nonbonding renewable energy goals (Table 3.3.2). In addition, a number of states have increased their renewable energy standards in recent years. In conjunction with system benefits funds, RPS policies are expected to lead to the development of more than $29,000 \mathrm{MW}$ of new renewable energy capacity by 2017 (Figure 3.3.2).

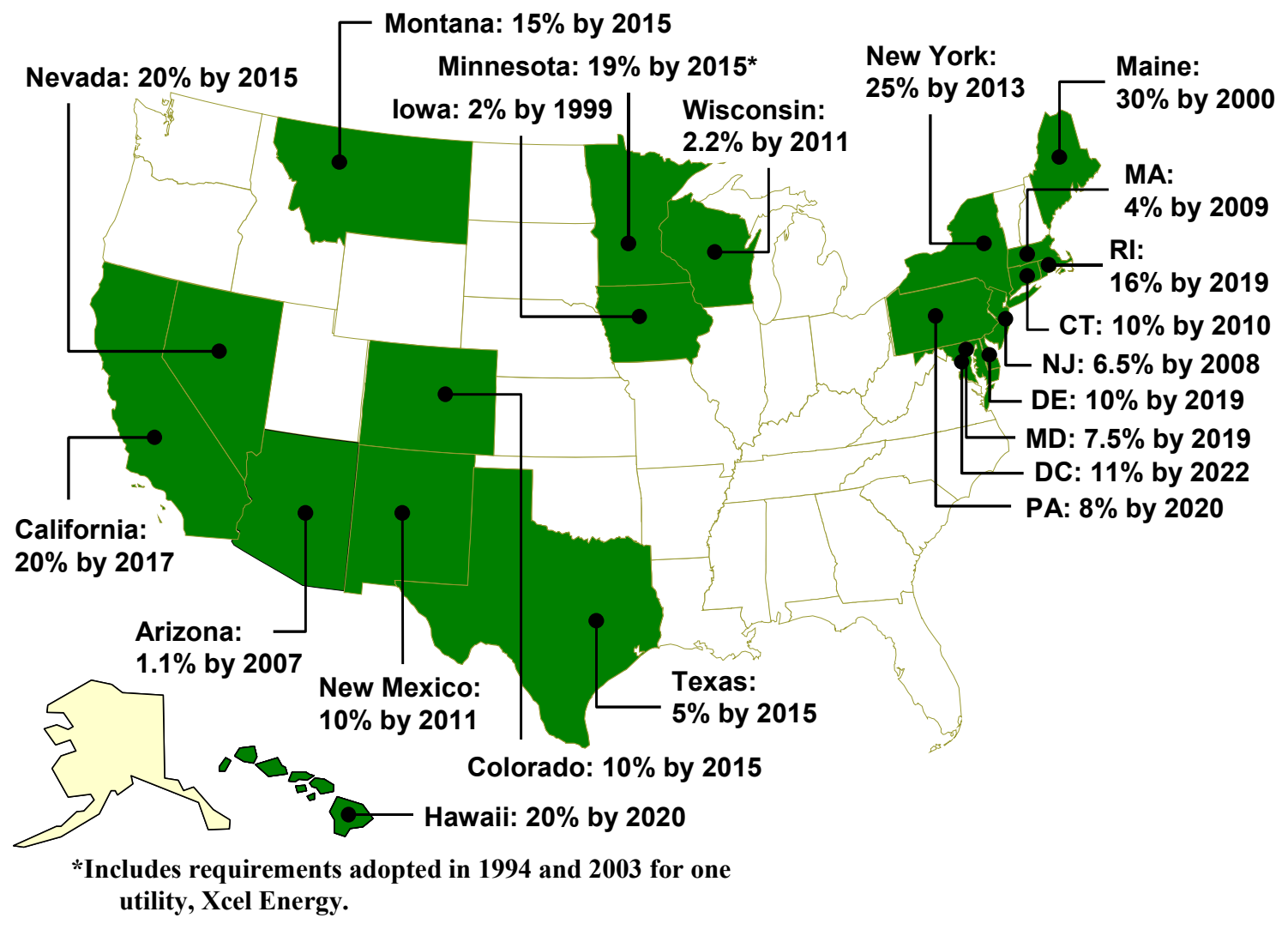

Source: NREL/Union of Concerned Scientists, October 2005

Figure 3.3.1: Renewable Portfolio Standards and Renewables Purchase Obligations by State 
Table 3.3.1: State Renewable Portfolio Standards and Purchase Requirements

\begin{tabular}{|c|c|c|c|c|}
\hline State & $\begin{array}{c}\text { Purchase } \\
\text { Requirements }\end{array}$ & Eligible Resources & Credit Trading & Penalties \\
\hline$A Z$ & $\begin{array}{l}15 \% \text { by } 2015 \text { (of this } \\
30 \% \text { must be customer } \\
\text { sited) }\end{array}$ & $\begin{array}{l}\text { PV and solar thermal electric, } \\
\text { R\&D, solar hot water, and in- } \\
\text { state landfill gas, wind, and } \\
\text { biomass. }\end{array}$ & $\begin{array}{l}\text { No central credit } \\
\text { trading system }\end{array}$ & $\begin{array}{l}\text { Under } \\
\text { consideratio } \\
\mathrm{n}\end{array}$ \\
\hline CA & $\begin{array}{l}\text { Investor-owned utilities } \\
\text { must add minimum } 1 \% \\
\text { annually to } 20 \% \text { by } \\
2017 \text {. }\end{array}$ & $\begin{array}{l}\text { Biomass, solar thermal, } \\
\text { photovoltaic, wind, geothermal, } \\
\text { existing hydro } \\
<30 \mathrm{MW} \text {, fuel cells using } \\
\text { renewable fuels, digester gas, } \\
\text { landfill gas, ocean energy. }\end{array}$ & $\begin{array}{l}\text { WREGIS system } \\
\text { under development }\end{array}$ & $\begin{array}{l}\text { At discretion } \\
\text { of CPUC }\end{array}$ \\
\hline $\mathrm{CO}$ & $10 \%$ by 2015 & $\begin{array}{l}\text { Photovoltaics, Landfill Gas, } \\
\text { Wind, Biomass, Geothermal } \\
\text { Electric, Anaerobic Digestion, } \\
\text { Small Hydroelectric, Fuel Cells } \\
\text { (Renewable Fuels) }\end{array}$ & $\begin{array}{l}\text { WREGIS system } \\
\text { under development }\end{array}$ & $\begin{array}{l}\text { To be } \\
\text { determined }\end{array}$ \\
\hline CT & $\begin{array}{l}3 \% \text { Class I or II } \\
\text { Technologies by Jan } 1 \text {, } \\
2004 \\
\text { Class I } 1 \% \text { Jan } 1,2004 \\
\text { increasing to } 1.5 \% \text { by } \\
2005,2 \% \text { by } 2006 \text {, } \\
3.5 \% \text { by } 2007,5 \% \text { by } \\
2008,6 \% \text { by } 2009 \text {, and } \\
7 \% \text { by Jan } 1,2010\end{array}$ & $\begin{array}{l}\text { Class I: solar, wind, new } \\
\text { sustainable biomass, landfill gas, } \\
\text { fuel cells, ocean thermal, wave, } \\
\text { tidal, advanced renewable } \\
\text { energy conversion technologies, } \\
\text { new run of river hydro (<5 MW). } \\
\text { Class II: licensed hydro, MSW, } \\
\text { and other biomass. }\end{array}$ & $\begin{array}{l}\text { Yes. Using } \\
\text { NEPOOL } \\
\text { Generation } \\
\text { Information } \\
\text { System. }\end{array}$ & $\begin{array}{l}\text { Penalty of } \\
5.5 \phi / \mathrm{kWh} \\
\text { paid to the } \\
\text { Renewable } \\
\text { Energy } \\
\text { Investment } \\
\text { Fund for the } \\
\text { development } \\
\text { of Class I } \\
\text { renewables }\end{array}$ \\
\hline$\overline{D E}$ & $10 \%$ by 2019 & $\begin{array}{l}\text { Solar Thermal Electric, } \\
\text { Photovoltaics, Landfill Gas, } \\
\text { Wind, Biomass, Hydroelectric, } \\
\text { Geothermal Electric, Anaerobic } \\
\text { Digestion, Tidal Energy, Wave } \\
\text { Energy, Ocean Thermal, Fuel } \\
\text { Cells (Renewable Fuels) }\end{array}$ & Yes. GATS & $\begin{array}{l}\text { Penalty of } \\
2.5 \phi / \mathrm{kWh} \\
\text { (increases to } \\
5 \phi / \mathrm{kWh} \text { for } \\
\text { multi-year } \\
\text { noncomplian } \\
\text { ce) }\end{array}$ \\
\hline $\mathrm{DC}$ & $\begin{array}{l}11 \% \text { by } 2022(0.386 \% \\
\text { solar) }\end{array}$ & $\begin{array}{l}\text { Solar Thermal Electric, } \\
\text { Photovoltaics, Landfill Gas, } \\
\text { Wind, Biomass, Hydroelectric, } \\
\text { Geothermal Electric, Municipal } \\
\text { Solid Waste, Cofiring, Tidal } \\
\text { Energy, Wave Energy, Ocean } \\
\text { Thermal }\end{array}$ & $\begin{array}{l}\text { Yes. GATS. } \\
\text { Electric delivery } \\
\text { requirement to PJM }\end{array}$ & $\begin{array}{l}\text { Penalty of } \\
2.5 \phi / k W h \text { for } \\
\text { tier } 1 \\
\text { resources, } \\
1 \phi / \mathrm{kWh} \text { for } \\
\text { tier II, and } \\
30 \phi / \mathrm{kWh} \text { for } \\
\text { PV }\end{array}$ \\
\hline $\mathrm{HI}$ & $\begin{array}{l}8 \% \text { by end of } 2005 \\
10 \% \text { by } 2010,15 \% \text { by } \\
2015 \text { and } 20 \% \text { by } 2020\end{array}$ & $\begin{array}{l}\text { Wind, solar, hydropower, } \\
\text { biomass including landfill gas, } \\
\text { waste to energy, and fuels } \\
\text { derived from organic sources, } \\
\text { geothermal, ocean energy, fuel } \\
\text { cells using hydrogen from } \\
\text { renewables }\end{array}$ & No & $\begin{array}{l}\text { Unspecified; } \\
\text { standard to } \\
\text { be revisited } \\
\text { if utilities can } \\
\text { not meet it in } \\
\text { cost- } \\
\text { effective } \\
\text { manner }\end{array}$ \\
\hline IA & $\begin{array}{l}\text { Investor-owned utilities } \\
\text { to purchase } 105 \mathrm{MW} \\
\text { ( } 2 \% \text { of } 1999 \text { sales) }\end{array}$ & $\begin{array}{l}\text { Solar, wind, methane recovery, } \\
\text { and biomass }\end{array}$ & No & Unspecified \\
\hline $\mathrm{ME}$ & $\begin{array}{l}30 \% \text { of retail sales in } \\
2000 \text { and thereafter. } \\
\text { PUC will revisit within } 5 \\
\text { years. }\end{array}$ & $\begin{array}{l}\text { Fuel cells, tidal, solar, wind, } \\
\text { geothermal, hydro, biomass, and } \\
\text { MSW (<100MW); high efficiency } \\
\text { cogeneration. Self-generation is } \\
\text { not eligible. Resource supply } \\
\text { under this definition exceeds } \\
\text { RPS requirement. }\end{array}$ & $\begin{array}{l}\text { Yes. NEPOOL } \\
\text { Generation } \\
\text { Information } \\
\text { System. }\end{array}$ & $\begin{array}{l}\text { Possible } \\
\text { sanctions at } \\
\text { discretion of } \\
\text { PUC }\end{array}$ \\
\hline
\end{tabular}




\begin{tabular}{|c|c|c|c|c|}
\hline State & $\begin{array}{c}\text { Purchase } \\
\text { Requirements }\end{array}$ & Eligible Resources & Credit Trading & Penalties \\
\hline MD & $\begin{array}{l}3.5 \% \text { by } 2006 \text { with } 1 \% \\
\text { from Tier } 1 \text { sources, } \\
\text { Tier } 1 \text { increasing by } 1 \% \\
\text { every other year from } \\
2007 \text { to } 2018, \text { Tier II } \\
\text { remains at } 2.5 \%, 7.5 \% \\
\text { total by } 2019 \text { and in } \\
\text { subsequent years }\end{array}$ & $\begin{array}{l}\text { Tier 1: solar, wind, geothermal, } \\
\text { qualifying biomass, small } \\
\text { hydropower (<30MW), and } \\
\text { landfill methane } \\
\text { Tier II: existing large hydropower, } \\
\text { poultry litter incineration, existing } \\
\text { waste to energy }\end{array}$ & Yes & $\begin{array}{l}\text { Alternative } \\
\text { Compliance } \\
\text { fee of } \\
2 \phi / \mathrm{kWh} \text { for } \\
\text { Tier } 1 \text { and } \\
1.5 \phi / \mathrm{kWh} \text { for } \\
\text { Tier } 2 \text { paid } \\
\text { to Maryland } \\
\text { Renewable } \\
\text { Energy Fund }\end{array}$ \\
\hline MA & $\begin{array}{l}1 \% \text { of sales to end-use } \\
\text { customers from new } \\
\text { renewables in } 2003, \\
+0.5 \% / y r \text { to } 4 \% \text { in } 2009 \\
1 \% / y r \text { increase } \\
\text { thereafter until } \\
\text { determined by Division } \\
\text { of Energy Resources }\end{array}$ & $\begin{array}{l}\text { New renewables placed into } \\
\text { commercial operation after 1997, } \\
\text { including solar, wind, ocean } \\
\text { thermal, wave, tidal, fuel cells } \\
\text { using renewable fuels, landfill } \\
\text { gas, and low-emission advanced } \\
\text { biomass. Excess production from } \\
\text { existing generators over } \\
\text { historical baseline eligible. }\end{array}$ & $\begin{array}{l}\text { Yes. Using } \\
\text { NEPOOL } \\
\text { Generation } \\
\text { Information } \\
\text { System. }\end{array}$ & $\begin{array}{l}\text { Entities may } \\
\text { comply by } \\
\text { paying } \\
5 \phi / \mathrm{kWh} \text {. } \\
\text { Non- } \\
\text { complying } \\
\text { retailers } \\
\text { must submit } \\
\text { a } \\
\text { compliance } \\
\text { plan. } \\
\text { Revocation } \\
\text { or } \\
\text { suspension } \\
\text { of license is } \\
\text { possible. }\end{array}$ \\
\hline $\mathrm{MN}$ & $\begin{array}{l}\text { (Not true RPS) Applies } \\
\text { to Xcel Energy only: } \\
425 \mathrm{MW} \text { wind by } 2002 \\
\text { and } 110 \mathrm{MW} \text { biomass. } \\
\text { Additional } 400 \mathrm{MW} \text { wind } \\
\text { by } 2006 \text { and } 300 \mathrm{MW} \\
\text { by } 2010\end{array}$ & Wind, biomass. & $\begin{array}{l}\text { No, other than } \\
\text { standard regulatory } \\
\text { oversight. }\end{array}$ & No \\
\hline MT & $\begin{array}{l}5 \% \text { in } 2008 ; 10 \% \text { in } \\
2010 ; 15 \% \text { in } 2015\end{array}$ & $\begin{array}{l}\text { Solar Thermal Electric, } \\
\text { Photovoltaics, Landfill Gas, } \\
\text { Wind, Biomass, Hydroelectric, } \\
\text { Geothermal Electric, Anaerobic } \\
\text { Digestion, Fuel Cells (Renewable } \\
\text { Fuels) }\end{array}$ & $\begin{array}{l}\text { Yes. Electricity } \\
\text { must be delivered } \\
\text { to MT. }\end{array}$ & $\begin{array}{l}\text { Penalty of } \\
1 \phi / \mathrm{kWh} \\
\text { goes to } \\
\text { universal } \\
\text { low-income } \\
\text { energy } \\
\text { assistance } \\
\text { fund. }\end{array}$ \\
\hline NV & $\begin{array}{l}6 \% \text { in } 2005 \text {, rising to } \\
20 \% \text { by } 2015 \text {. } \\
\text { Minimum } 5 \% \text { must } \\
\text { come from solar. }\end{array}$ & $\begin{array}{l}\text { Solar, wind, geothermal, \& } \\
\text { biomass (includes agricultural } \\
\text { waste, wood, MSW, animal } \\
\text { waste and aquatic plants). } \\
\text { Distributed resources receives } \\
\text { extra credit (1.15). }\end{array}$ & Yes. & $\begin{array}{l}\text { Financial } \\
\text { penalties } \\
\text { may be } \\
\text { applied for } \\
\text { noncomplian } \\
\text { ce. }\end{array}$ \\
\hline NJ & $\begin{array}{l}\text { Class I or II: } 2.5 \% \text { by } \\
2008 \\
\text { Class I: } 4 \% \text { by } 2008 \text {, } \\
\text { with solar requirement } \\
\text { of } 0.16 \% \text { retail sales } \\
(90 \mathrm{MW}) \\
\text { Goal of } 20 \% \text { by } 2020 \text {. }\end{array}$ & $\begin{array}{l}\text { Class I.: Solar, PV, wind, fuel } \\
\text { cells, geothermal, wave, tidal, } \\
\text { landfill methane, and sustainable } \\
\text { biomass. } \\
\text { Class II: hydro }<30 \mathrm{MW} \text { and } \\
\text { MSW facilities that meet air } \\
\text { pollution requirements. }\end{array}$ & Yes. GATS. & $\begin{array}{l}\text { Alternative } \\
\text { Compliance } \\
\text { Payment of } \\
5 \phi / k W h, \\
30 / / k W h \text { for } \\
\text { solar. }\end{array}$ \\
\hline NM & $\begin{array}{l}5 \% \text { of retail sales by } \\
2006 . \text { Increase by } 1 \% / y r \\
\text { to } 10 \% \text { by January } 1 \text {, }\end{array}$ & $\begin{array}{l}\text { Solar, wind, hydro }(<=5 \mathrm{MW}) \\
\text { biomass, geothermal, and fuel } \\
\text { cells. } 1 \mathrm{kWh} \text { solar }=3 \mathrm{kWh} ; 1\end{array}$ & $\begin{array}{l}\text { Yes. RECs valid for } \\
4 \text { years from date } \\
\text { of issuance. }\end{array}$ & $\begin{array}{l}\text { At discretion } \\
\text { of PUC. }\end{array}$ \\
\hline
\end{tabular}




\begin{tabular}{|c|c|c|c|c|}
\hline State & $\begin{array}{c}\text { Purchase } \\
\text { Requirements }\end{array}$ & Eligible Resources & Credit Trading & Penalties \\
\hline & 2011 and thereafter. & $\begin{array}{l}\text { kWh biomass, geothermal, } \\
\text { landfill gas, or fuel cells }=2 \mathrm{kWh} \\
\text { toward compliance }\end{array}$ & & \\
\hline NY & $\begin{array}{l}25 \% \text { by } 2013 ; 1 \% \\
\text { voluntary standard; } 2 \% \\
\text { of total incremental RPS } \\
\text { requirement }(7.71 \%) \text { is } \\
\text { set-aside for customer- } \\
\text { sited }\end{array}$ & $\begin{array}{l}\text { Photovoltaics, Landfill Gas, } \\
\text { Wind, Biomass, Hydroelectric, } \\
\text { Fuel Cells, CHP/Cogeneration, } \\
\text { Biogas, Liquid Biofuel, Anaerobic } \\
\text { Digestion, Tidal Energy, Wave } \\
\text { Energy, Ocean Thermal }\end{array}$ & $\begin{array}{l}\text { Possibly. Electricity } \\
\text { must be delivered } \\
\text { to NY. }\end{array}$ & Unspecified. \\
\hline PA & $\begin{array}{l}18 \% \text { by } 2020 ; 8 \% \text { Tier } 1 \\
\text { and } 10 \% \text { Tier II } \\
\text { Solar set-aside of } 0.5 \% \\
\text { by } 2020\end{array}$ & $\begin{array}{l}\text { Solar Water Heat, Solar Space } \\
\text { Heat, Solar Thermal Electric, } \\
\text { Solar Thermal Process Heat, } \\
\text { Photovoltaics, Landfill Gas, } \\
\text { Wind, Biomass, Hydroelectric, } \\
\text { Geothermal Electric, Fuel Cells, } \\
\text { Municipal Solid Waste, } \\
\text { CHP/Cogeneration, Waste Coal, } \\
\text { Coal Mine Methane, Coal } \\
\text { Gasification, Anaerobic } \\
\text { Digestion, Other Distributed } \\
\text { Generation Technologies }\end{array}$ & Yes. GATS & $\begin{array}{l}\text { Penalty of } \\
4.5 \phi / k W h \text {, } \\
\text { for solar } \\
\text { penalty is } \\
200 \% \text { of } P V \\
\text { REC value. }\end{array}$ \\
\hline RI & $\begin{array}{l}16 \% \text { by } 2020 ; 3 \% \text { by } \\
2003 \text {, increasing } 0.5 \% \\
\text { annually } 2008-2010, \\
\text { increasing } 1 \% \text { annually } \\
2011-2014 \text {, increasing } \\
1.5 \% \text { annually } 2015- \\
2019\end{array}$ & $\begin{array}{l}\text { Solar, wind, eligible biomass, } \\
\text { including co-firing, geothermal, } \\
\text { small hydropower, ocean, fuel } \\
\text { cells using hydrogen derived } \\
\text { from renewables }\end{array}$ & $\begin{array}{l}\text { Yes. NEPOOL } \\
\text { Generation } \\
\text { Information } \\
\text { System. }\end{array}$ & $\begin{array}{l}\text { Penalty of } \\
5 \phi / k W h \text { can } \\
\text { be made to } \\
\text { Renewable } \\
\text { Energy } \\
\text { Developmen } \\
\text { t Fund }\end{array}$ \\
\hline TX & $\begin{array}{l}5880 \mathrm{MW} \text { by } 2015 \\
(5000 \mathrm{MW} \text { new) } \\
\text { Target of at least } 500 \\
\text { MW from renewables } \\
\text { other than wind }\end{array}$ & $\begin{array}{l}\text { Solar, wind, geothermal, hydro, } \\
\text { wave, tidal, biomass, including } \\
\text { landfill gas. New (operational } \\
\text { after Sept. 1, 1999) or small } \\
\text { (<2MW) facilities eligible. }\end{array}$ & $\begin{array}{l}\text { Yes. ERCOT REC } \\
\text { Trading System. }\end{array}$ & $\begin{array}{l}\text { Lesser of } \\
5 \phi / \mathrm{kWh} \text { or } \\
200 \% \text { of } \\
\text { average } \\
\text { market value } \\
\text { of renewable } \\
\text { energy } \\
\text { credits. }\end{array}$ \\
\hline WI & $\begin{array}{l}0.5 \% \text { by } 2001 \\
\text { increasing to } 2.2 \% \text { by } \\
2011(0.6 \% \text { can come } \\
\text { from facilities installed } \\
\text { prior to } 1998) \text {. }\end{array}$ & $\begin{array}{l}\text { Wind, solar, biomass, } \\
\text { geothermal, tidal, fuel cells that } \\
\text { use renewable fuel, \& hydro } \\
\text { under } 60 \mathrm{MW} \text {. Eligibility may be } \\
\text { extended by PUC. }\end{array}$ & $\begin{array}{l}\text { Yes. Utilities with } \\
\text { excess RECs can } \\
\text { trade or bank them. }\end{array}$ & $\begin{array}{l}\text { Penalty of } \\
\$ 5,000- \\
\$ 500,000 \text { is } \\
\text { allowed in } \\
\text { legislation. }\end{array}$ \\
\hline
\end{tabular}

Source: Table updated by NREL, March 2006. Derived from table in Wiser, R. Porter, K., Grace, R., Kappel, C. Creating Geothermal Markets: Evaluating Experience with State Renewables Portfolio Standards, report prepared for the National Geothermal Collaborative, 2003. 
Table 3.3.2: State Renewable Energy Goals (Nonbinding)

\begin{tabular}{|l|l|l|}
\hline \multicolumn{1}{|c|}{ State } & \multicolumn{1}{|c|}{ Purchase Requirements } & \multicolumn{1}{c|}{ Eligible Resources } \\
\hline Illinois & $8 \%$ by $2013(75 \%$ wind $)$ & $\begin{array}{l}\text { Solar Water Heat, Solar Thermal Electric, } \\
\text { Photovoltaics, Landfill Gas, Wind, Biomass, } \\
\text { Hydroelectric, CHP/Cogeneration, "Other Such } \\
\text { Alternative Sources of Environmentally } \\
\text { Preferable Energy" }\end{array}$ \\
\hline Minnesota & $\begin{array}{l}1 \% \text { by } 2005 \text { increasing by at least } \\
1 \% / \text { year to } 10 \% \text { by } 2015\end{array}$ & Wind, solar, hydro (<60 MW), and biomass \\
\hline Vermont & $\begin{array}{l}\text { Meet growth in electricity demand from } \\
2005-2013 \text { with renewable energy } \\
\text { sources (becomes mandatory in } 2013 \text { if } \\
\text { not met). }\end{array}$ & $\begin{array}{l}\text { Solar Thermal Electric, Photovoltaics, Landfill } \\
\text { Gas, Wind, Biomass, Hydroelectric, Anaerobic } \\
\text { Digestion, Fuel Cells (Renewable Fuels) }\end{array}$ \\
\hline
\end{tabular}

Source: NREL, March 2006.

Nationwide the RPS requirements for renewable energy are estimated to total 2,335 MW of generating capacity. The vast majority $(93.5 \%)$ is wind power, followed by biomass $(2.3 \%)$, landfill gas $(2.3 \%)$, hydropower $(1.3 \%)$, solar energy $(0.4 \%)$, and other $(0.3 \%)$. The five largest states in terms of capacity are Texas, Minnesota, Iowa, California, and Wisconsin.

Table 3.3.3 Estimated Renewable Energy Capacity Satisfying RPS Requirements Through 2003 (Megawatts, Nameplate Capacity)

\begin{tabular}{|c|c|c|c|c|c|c|c|}
\hline State & Biomass & Hydro & $\begin{array}{l}\text { Landfill } \\
\text { Gas }\end{array}$ & $\begin{array}{c}\text { Solar } \\
\text { Photovoltaic } \\
\text { s }\end{array}$ & Wind & $\begin{array}{c}\text { Otherl } \\
\text { Unknown }\end{array}$ & Total \\
\hline Arizona & 0 & 0 & 5 & 9 & 0 & 0 & 14 \\
\hline California & 0 & 20 & 6 & 0 & 175 & 0 & 201 \\
\hline Connecticut & 0 & 0 & 0 & 0 & 0 & 0 & 0 \\
\hline Maine & 0 & 0 & 0 & 0 & 0 & 0 & 0 \\
\hline Massachusetts & 0 & 0 & 8 & 0 & 1 & 0 & 9 \\
\hline Nevada & 0 & 0 & 0 & 0 & 0 & 0 & 0 \\
\hline New Jersey & 0 & 0 & 0 & 0 & 0 & 0 & 0 \\
\hline New Mexico & 0 & 0 & 0 & 0 & 0 & 0 & 0 \\
\hline Wisconsin & 0 & 0 & 3 & 0 & 94 & 0 & 97 \\
\hline lowa & 16 & 0 & 0 & 0 & 237 & 7 & 260 \\
\hline Minnesota & 25 & 0 & 0 & 0 & 476 & 0 & 501 \\
\hline Texas & 5 & 10 & 31 & 0.2 & 1,140 & 0 & 1,186 \\
\hline Wisconsin & 7 & 0 & 0 & 0 & 50 & 0 & 57 \\
\hline Hawaii & 0 & 0 & 0 & 0 & 0 & 0 & 0 \\
\hline Illinois & 0 & 0 & 0 & 0 & 0 & 0 & 0 \\
\hline Minnesota & 0 & 0 & 0 & 0 & 0 & 0 & 0 \\
\hline Pennsylvania & 0 & 0 & 0 & 0 & 10 & 0 & 10 \\
\hline Total & 53 & 30 & 53 & 9.2 & 2,183 & 7 & 2,335 \\
\hline Share of Total & $2.3 \%$ & $1.3 \%$ & $2.3 \%$ & $0.4 \%$ & $93.5 \%$ & $0.3 \%$ & $100.0 \%$ \\
\hline
\end{tabular}

Source: Petersick, T. 2004. State Renewable Energy Requirements and Goals: Status Through 2003, U.S.

DOE Energy Information Administration, July http://www.eia.doe.gov/oiaf/analysispaper/rps/index.html 


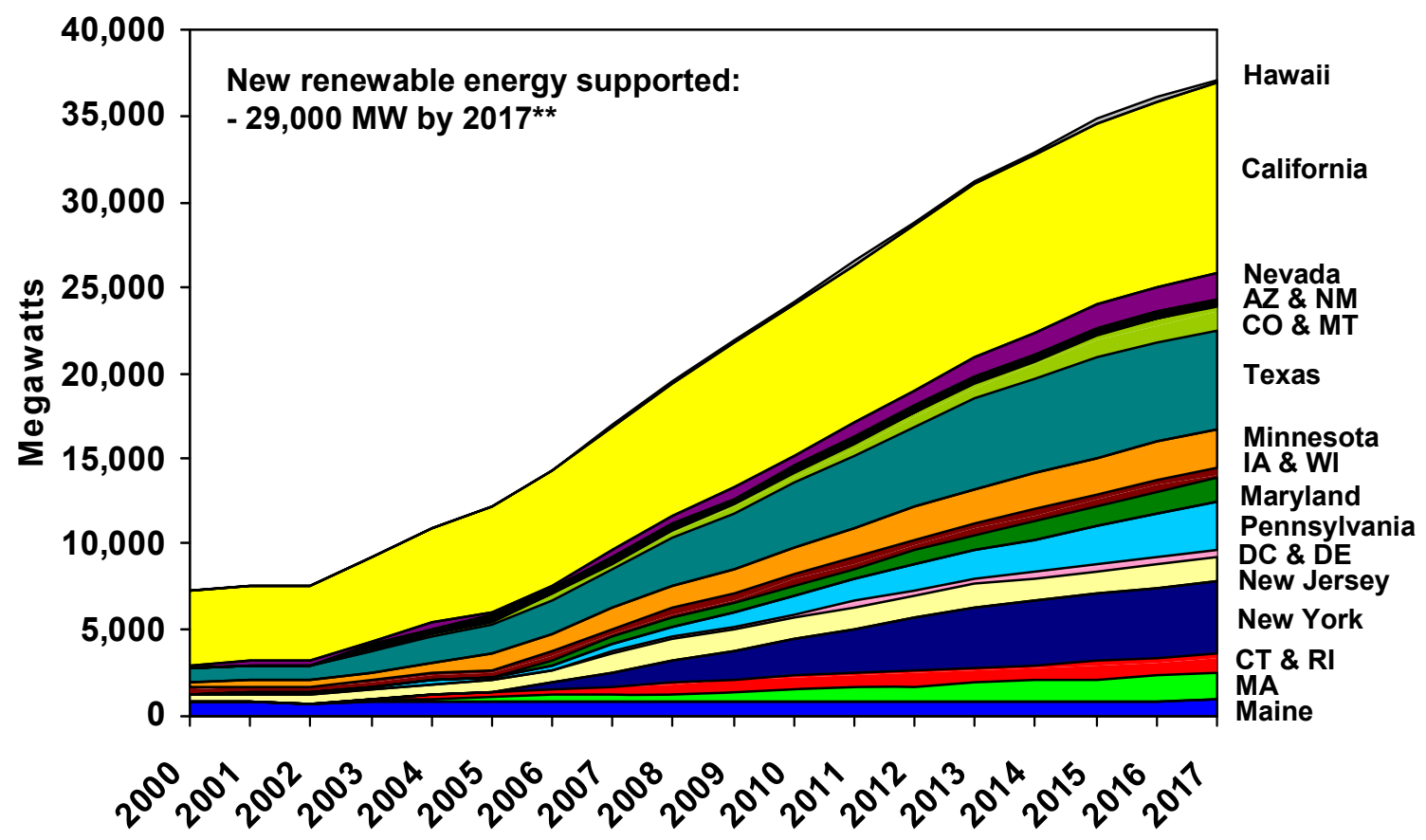

${ }^{*}$ Projected development assuming states achieve annual RES targets.

**If achieved, IA, IL, and MN goals would support an additional 5,300 MW by 2017.

Source: Union of Concerned Scientists, November 2005.

Figure 3.3.2: The Future Impact of State Purchase Mandates and Renewable Energy Funds 


\section{4 - States with Net Metering Policies}

Net metering allows customers with generating facilities to turn their electric meters backward when their systems are producing energy in excess of their on-site demand. In this way, net metering enables customers to use their own generation to offset their consumption over a billing period. This offset means that customers receive retail prices for the excess electricity they generate. Without net metering, a second meter is usually installed to measure the electricity that flows back to the provider, with the provider purchasing the power at a rate much lower than the retail rate.

Most states have some type of net metering policy (Figure 3.4.1). Of the states that do have net metering policies (Table 3.4.1) the policies vary significantly in terms of the maximum amount of capacity a consumer is permitted to net meter varies from $10 \mathrm{~kW}$ to $2,000 \mathrm{~kW}$. Some states only require certain types of utilities to offer net metering, exempting others.

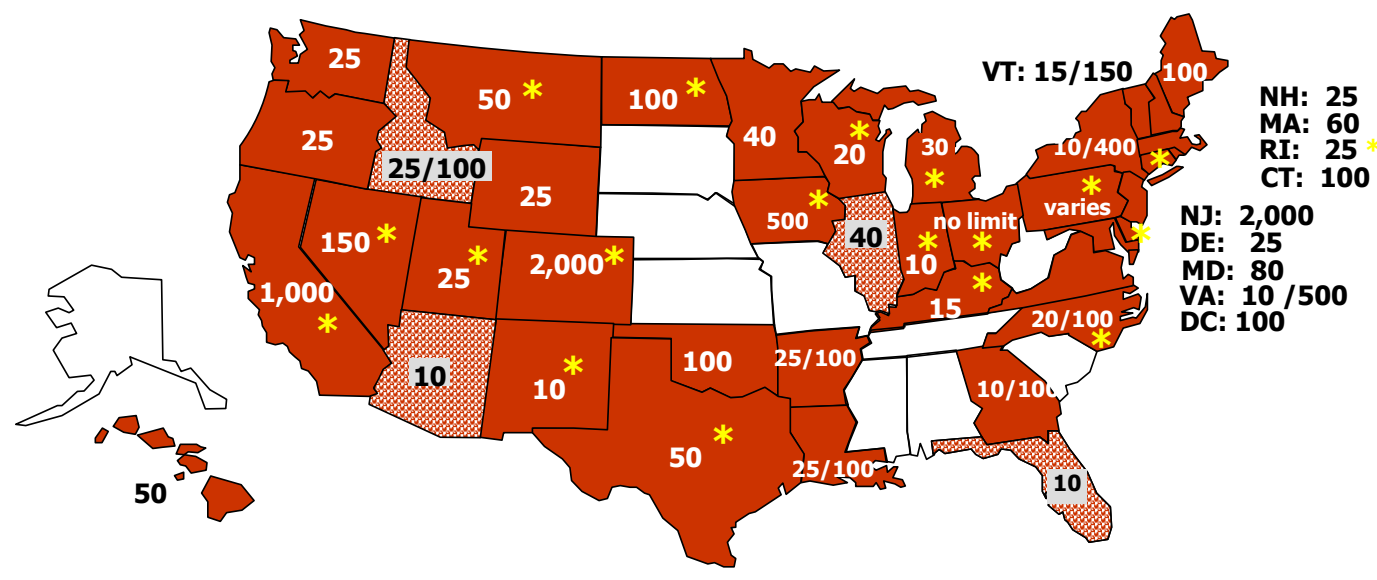

State-wide net metering for all utility types

State-wide net metering for certain utility types (e.g., IOUs only)

Net metering offered by one or more individual utilities

\#s indicate system size limit (kW); in some cases limits are different for residential and commercial as shown

Source: DSIRE database, January 2006

http://www.dsireusa.org/library/includes/topic.cfm?TopicCategorylD=6\&CurrentPageID=10

Figure 3.4.1: Net Metering Policies by State 
Table 3.4.1: Summary of State Net Metering Policies

\begin{tabular}{|c|c|c|c|c|c|c|}
\hline Program & \begin{tabular}{|c|} 
System Size \\
Limit/ \\
Customer \\
Classes \\
Eligible \\
\end{tabular} & $\begin{array}{c}\text { Eligible } \\
\text { Technologies }\end{array}$ & $\begin{array}{l}\text { Limit on } \\
\text { Total } \\
\text { Capacity }\end{array}$ & $\begin{array}{l}\text { Treatment of } \\
\text { Net Excess } \\
\text { Generation } \\
\text { (NEG) }\end{array}$ & $\begin{array}{l}\text { Interconnection } \\
\text { Standards for } \\
\text { Net Metering }\end{array}$ & $\begin{array}{l}\text { Utilities } \\
\text { Involved }\end{array}$ \\
\hline $\begin{array}{l}\text { Arizona - } \\
\text { Salt River } \\
\text { Project }\end{array}$ & $\begin{array}{l}10 \mathrm{~kW} / \\
\text { Residential }\end{array}$ & Photovoltaics & None & $\begin{array}{l}\text { Purchased } \\
\text { monthly by utility } \\
\text { at average } \\
\text { monthly market } \\
\text { price minus a } \\
\text { price adjustment } \\
\text { of } \\
\$ 0.00017 / \mathrm{kWh}\end{array}$ & $\begin{array}{l}\text { (Utility } \\
\text { guidelines) }\end{array}$ & $\begin{array}{l}\text { Salt River } \\
\text { Project }\end{array}$ \\
\hline $\begin{array}{l}\text { Arizona - } \\
\text { Tucson } \\
\text { Electric Power }\end{array}$ & $\begin{array}{l}10 \mathrm{~kW} / \\
\text { Commercial, } \\
\text { Residential }\end{array}$ & $\begin{array}{l}\text { Photovoltaics, } \\
\text { Wind }\end{array}$ & $\begin{array}{l}500 \mathrm{~kW} \\
\text { peak } \\
\text { aggregate }\end{array}$ & $\begin{array}{l}\text { Credited at retail } \\
\text { rate to } \\
\text { customer's next } \\
\text { bill; granted to } \\
\text { utility at end of } \\
12-\text { month billing } \\
\text { cycle }\end{array}$ & $\begin{array}{l}\text { (Utility } \\
\text { guidelines) }\end{array}$ & \begin{tabular}{|l} 
Tucson \\
Electric \\
Power
\end{tabular} \\
\hline Arkansas & $\begin{array}{l}25 \mathrm{~kW} \text { for } \\
\text { residential } \\
\text { systems; } \\
100 \mathrm{~kW} \text { for } \\
\text { commercial } \\
\text { systems }\end{array}$ & $\begin{array}{l}\text { Solar, Wind, } \\
\text { Biomass, } \\
\text { Hydro, } \\
\text { Geothermal, } \\
\text { Fuel Cells, } \\
\text { Microturbines } \\
\end{array}$ & None & $\begin{array}{l}\text { Granted to utility } \\
\text { monthly }\end{array}$ & Yes & All utilities \\
\hline California & $\begin{array}{l}1 \text { MW (three } \\
\text { biogas } \\
\text { digesters up } \\
\text { to } 10 \text { MW per } \\
\text { unit may net } \\
\text { meter) / } \\
\text { Commercial, } \\
\text { Industrial, } \\
\text { Residential }\end{array}$ & $\begin{array}{l}\text { Photovoltaics, } \\
\text { Landfill Gas, } \\
\text { Wind, } \\
\text { Anaerobic } \\
\text { Digestion, } \\
\text { Fuel Cells }\end{array}$ & $\begin{array}{l}0.5 \% \text { of a } \\
\text { utility's peak } \\
\text { demand } \\
\text { (separate } \\
\text { limit of } 50 \\
\text { MW for } \\
\text { SDG\&E) }\end{array}$ & $\begin{array}{l}\text { Credited at retail } \\
\text { rate to } \\
\text { customer's next } \\
\text { bill; granted to } \\
\text { utility at end of } \\
12-\text { month billing } \\
\text { cycle }\end{array}$ & Yes & All utilities ${ }^{1}$ \\
\hline Colorado & $\begin{array}{l}2 \mathrm{MW} / \\
\text { Commercial, } \\
\text { Industrial, } \\
\text { Residential }\end{array}$ & $\begin{array}{l}\text { Solar, Landfill } \\
\text { Gas, Wind, } \\
\text { Biomass, } \\
\text { Anaerobic } \\
\text { Digestion, } \\
\text { Small Hydro, } \\
\text { Fuel Cells } \\
\text { (Renewable } \\
\text { Fuels) }\end{array}$ & None & $\begin{array}{l}\text { Credited at retail } \\
\text { rate to } \\
\text { customer's next } \\
\text { bill; at end of } \\
\text { each calendar } \\
\text { year, customer } \\
\text { reimbursed for } \\
\text { NEG at utility's } \\
\text { average hourly } \\
\text { incremental cost } \\
\text { for the prior 12- } \\
\text { month period }\end{array}$ & Yes & $\begin{array}{l}\text { Colorado } \\
\text { utilities } \\
\text { serving } \\
40,000 \text { or } \\
\text { more } \\
\text { customers }\end{array}$ \\
\hline $\begin{array}{l}\text { Colorado - } \\
\text { Fort Collins } \\
\text { Utilities }\end{array}$ & $\begin{array}{l}10 \text { kW / } \\
\text { Residential }\end{array}$ & $\begin{array}{l}\text { Photovoltaics, } \\
\text { Wind }\end{array}$ & 25 customers & $\begin{array}{l}\text { Credited at retail } \\
\text { rate to } \\
\text { customer's next } \\
\text { bill; granted to } \\
\text { utility at end of }\end{array}$ & Yes & $\begin{array}{l}\text { Fort Collins } \\
\text { Utilities }\end{array}$ \\
\hline
\end{tabular}

\footnotetext{
${ }^{1}$ In California, all utilities - with the exception of Los Angeles Department of Water \& Power (LADWP) -must offer net metering to customers with PV and wind-energy systems. (LADWP offers net metering voluntarily.) In addition, investor-owned utilities must offer net metering to customers with fuel cells and biomass-energy systems.
} 


\begin{tabular}{|c|c|c|c|c|c|c|}
\hline Program & \begin{tabular}{|c} 
System Size \\
Limit/ \\
Customer \\
Classes \\
Eligible
\end{tabular} & $\begin{array}{c}\text { Eligible } \\
\text { Technologies }\end{array}$ & $\begin{array}{l}\text { Limit on } \\
\text { Total } \\
\text { Capacity }\end{array}$ & $\begin{array}{l}\text { Treatment of } \\
\text { Net Excess } \\
\text { Generation } \\
\text { (NEG) }\end{array}$ & $\begin{array}{l}\text { Interconnection } \\
\text { Standards for } \\
\text { Net Metering }\end{array}$ & $\begin{array}{l}\text { Utilities } \\
\text { Involved }\end{array}$ \\
\hline & & & & $\begin{array}{l}\text { 12-month billing } \\
\text { cycle }\end{array}$ & & \\
\hline $\begin{array}{l}\text { Colorado - } \\
\text { Gunnison } \\
\text { County } \\
\text { Electric }\end{array}$ & $\begin{array}{l}10 \mathrm{~kW} / \\
\text { Commercial, } \\
\text { Residential }\end{array}$ & $\begin{array}{l}\text { Photovoltaics, } \\
\text { Wind }\end{array}$ & 50 customers & $\begin{array}{l}\text { Purchased by } \\
\text { utility at } \\
\text { wholesale rate }\end{array}$ & Yes & $\begin{array}{l}\text { Gunnison } \\
\text { County } \\
\text { Electric }\end{array}$ \\
\hline $\begin{array}{l}\text { Colorado - } \\
\text { Holy Cross } \\
\text { Energy }\end{array}$ & $\begin{array}{l}\text { None / } \\
\text { Commercial, } \\
\text { Industrial, } \\
\text { Residential }\end{array}$ & $\begin{array}{l}\text { Photovoltaics, } \\
\text { Wind, } \\
\text { Biomass, } \\
\text { Hydro, } \\
\text { Geothermal }\end{array}$ & $25 \mathrm{~kW}$ & $\begin{array}{l}\text { Credited at retail } \\
\text { rate to } \\
\text { customer's next } \\
\text { bill; purchased } \\
\text { by utility at } \\
\text { wholesale rate } \\
\text { at end of 12- } \\
\text { month billing } \\
\text { cycle }\end{array}$ & Yes & $\begin{array}{l}\text { Holy Cross } \\
\text { Energy }\end{array}$ \\
\hline Connecticut & $\begin{array}{l}100 \mathrm{~kW} \text { for } \\
\text { renewables; } \\
50 \mathrm{~kW} \text { for } \\
\text { fossil fuels / } \\
\text { Residential, } \\
\text { Commercial }\end{array}$ & $\begin{array}{l}\text { Solar, Landfill } \\
\text { Gas, Wind, } \\
\text { Biomass, Fuel } \\
\text { Cells, } \\
\text { Municipal } \\
\text { Solid Waste, } \\
\text { Small Hydro, } \\
\text { Tidal Energy, } \\
\text { Wave Energy, } \\
\text { Ocean } \\
\text { Thermal }\end{array}$ & None & $\begin{array}{l}\text { Purchased by } \\
\text { utility at spot- } \\
\text { market energy } \\
\text { rate }\end{array}$ & Yes & $\begin{array}{l}\text { Investor- } \\
\text { owned } \\
\text { utilities only }\end{array}$ \\
\hline Delaware & $\begin{array}{l}25 \mathrm{~kW} / \\
\text { Commercial, } \\
\text { Residential }\end{array}$ & $\begin{array}{l}\text { Solar, Wind, } \\
\text { Biomass, } \\
\text { Hydro, } \\
\text { Geothermal }\end{array}$ & None & Varies by utility & Yes & \begin{tabular}{|l} 
All utilities \\
(applies to \\
municipal \\
utilities if \\
they opt to \\
compete \\
outside their \\
limits)
\end{tabular} \\
\hline $\begin{array}{l}\text { District of } \\
\text { Columbia }\end{array}$ & $\begin{array}{l}100 \text { kW / } \\
\text { Commercial, } \\
\text { Industrial, } \\
\text { Residential }\end{array}$ & $\begin{array}{l}\text { Renewables } \\
\text { (unspecified), } \\
\text { Fuel Cells, } \\
\text { Microturbines, } \\
\text { CHP }\end{array}$ & None & $\begin{array}{l}\text { Credited at retail } \\
\text { rate to } \\
\text { customer's next } \\
\text { bill }\end{array}$ & $\begin{array}{l}\text { Yes (under } \\
\text { development) }\end{array}$ & All utilities \\
\hline $\begin{array}{l}\text { Florida - } \\
\text { JEA }\end{array}$ & $\begin{array}{l}10 \mathrm{~kW} / \\
\text { Residential }\end{array}$ & $\begin{array}{l}\text { Photovoltaics, } \\
\text { Wind }\end{array}$ & None & $\begin{array}{l}\text { Credited at retail } \\
\text { rate to } \\
\text { customer's next } \\
\text { bill }\end{array}$ & $\begin{array}{l}\text { (Utility } \\
\text { guidelines) }\end{array}$ & JEA \\
\hline $\begin{array}{l}\text { Florida - } \\
\text { New Smyrna } \\
\text { Beach Utilities }\end{array}$ & $\begin{array}{l}10 \text { kW / } \\
\text { Commercial, } \\
\text { Industrial, } \\
\text { Residential }\end{array}$ & Photovoltaics & None & $\begin{array}{l}\text { Credited at retail } \\
\text { rate to } \\
\text { customer's next } \\
\text { bill }\end{array}$ & $\begin{array}{l}\text { (Utility } \\
\text { guidelines) }\end{array}$ & $\begin{array}{l}\text { New Smyrna } \\
\text { Beach } \\
\text { Utilities }\end{array}$ \\
\hline Georgia & $\begin{array}{l}100 \mathrm{~kW} \text { for } \\
\text { commercial } \\
\text { systems; } \\
10 \mathrm{~kW} \text { for } \\
\text { residential } \\
\text { systems; }\end{array}$ & $\begin{array}{l}\text { Photovoltaics, } \\
\text { Wind, } \\
\text { Fuel Cells }\end{array}$ & \begin{tabular}{|l}
$0.2 \%$ of a \\
utility's \\
annual peak \\
demand
\end{tabular} & $\begin{array}{l}\text { Credited at retail } \\
\text { rate to } \\
\text { customer's next } \\
\text { bill; granted to } \\
\text { utility at end of } \\
\text { 12-month billing }\end{array}$ & Yes & All utilities \\
\hline
\end{tabular}




\begin{tabular}{|c|c|c|c|c|c|c|}
\hline Program & \begin{tabular}{|c|} 
System Size \\
Limit/ \\
Customer \\
Classes \\
Eligible \\
\end{tabular} & \begin{tabular}{|c|} 
Eligible \\
Technologies
\end{tabular} & $\begin{array}{l}\text { Limit on } \\
\text { Total } \\
\text { Capacity }\end{array}$ & $\begin{array}{l}\text { Treatment of } \\
\text { Net Excess } \\
\text { Generation } \\
\text { (NEG) }\end{array}$ & $\begin{array}{c}\text { Interconnection } \\
\text { Standards for } \\
\text { Net Metering }\end{array}$ & $\begin{array}{l}\text { Utilities } \\
\text { Involved }\end{array}$ \\
\hline & & & & Cycle & & \\
\hline Hawaii & $\begin{array}{l}50 \mathrm{~kW} / \\
\text { Commercial, } \\
\text { Residential, } \\
\text { Government }\end{array}$ & \begin{tabular}{|l|} 
Photovoltaics, \\
Wind, \\
Biomass, \\
Hydro
\end{tabular} & \begin{tabular}{|l}
$0.5 \%$ of a \\
utility's \\
annual peak \\
demand
\end{tabular} & $\begin{array}{l}\text { Credited at retail } \\
\text { rate to } \\
\text { customer's next } \\
\text { bill; granted to } \\
\text { utility at end of } \\
\text { 12-month billing } \\
\text { cycle }\end{array}$ & Yes & All utilities \\
\hline $\begin{array}{l}\text { Idaho - } \\
\text { Idaho Power }\end{array}$ & $\begin{array}{l}100 \mathrm{~kW} \text { for } \\
\text { large } \\
\text { commercial } \\
\text { and } \\
\text { agricultural; } \\
25 \mathrm{~kW} \text { for } \\
\text { residential } \\
\text { and small } \\
\text { commercial }\end{array}$ & $\begin{array}{l}\text { Photovoltaics, } \\
\text { Wind, } \\
\text { Biomass, } \\
\text { Hydro, Fuel } \\
\text { Cells }\end{array}$ & \begin{tabular}{|l}
$2.9 \mathrm{MW}$ \\
$(0.1 \%$ of \\
utility's 2000 \\
peak \\
demand)
\end{tabular} & \begin{tabular}{|l} 
Purchased \\
monthly by utility \\
at retail rate for \\
residential and \\
small \\
commercial \\
customers; \\
purchased at \\
$85 \%$ of Dow \\
Jones index \\
price for non- \\
firm energy for \\
large \\
commercial and \\
agricultural \\
customers
\end{tabular} & $\begin{array}{l}\text { (Utility } \\
\text { guidelines) }\end{array}$ & Idaho Power \\
\hline $\begin{array}{l}\text { Idaho - } \\
\text { Utah Power \& } \\
\text { Light }\end{array}$ & $\begin{array}{l}100 \mathrm{~kW} \text { for } \\
\text { large } \\
\text { commercial } \\
\text { and irrigation; } \\
25 \mathrm{~kW} \text { for } \\
\text { residential } \\
\text { and small } \\
\text { commercial }\end{array}$ & $\begin{array}{l}\text { Solar, Wind, } \\
\text { Biomass, } \\
\text { Hydro }\end{array}$ & $\begin{array}{l}714 \mathrm{~kW} \\
(0.1 \% \text { of } \\
\text { utility's Idaho } \\
\text { retail peak } \\
\text { demand in } \\
2002)\end{array}$ & \begin{tabular}{|l} 
Purchased \\
monthly by utility \\
at retail rate for \\
residential and \\
small \\
commercial \\
customers; \\
purchased at \\
$85 \%$ of Dow \\
Jones index \\
price for non- \\
firm energy for \\
large \\
commercial and \\
agricultural \\
customers \\
\end{tabular} & $\begin{array}{l}\text { (Utility } \\
\text { guidelines) }\end{array}$ & $\begin{array}{l}\text { Utah Power } \\
\& \text { Light }\end{array}$ \\
\hline $\begin{array}{l}\text { Idaho - } \\
\text { Avista Utilities }\end{array}$ & $\begin{array}{l}25 \mathrm{~kW} / \\
\text { Commercial, } \\
\text { Residential, } \\
\text { Agricultural }\end{array}$ & $\begin{array}{l}\text { Solar, Wind, } \\
\text { Biomass, } \\
\text { Hydro, Fuel } \\
\text { Cells }\end{array}$ & \begin{tabular}{|l}
$1.52 \mathrm{MW}$ \\
(0.1\% of \\
utility's 1996 \\
peak \\
demand)
\end{tabular} & $\begin{array}{l}\text { Credited at retail } \\
\text { rate to } \\
\text { customer's next } \\
\text { bill; granted to } \\
\text { utility at end of } \\
12-\text { month billing } \\
\text { cycle }\end{array}$ & $\begin{array}{l}\text { (Utility } \\
\text { guidelines) }\end{array}$ & \begin{tabular}{|l} 
Avista \\
Utilities
\end{tabular} \\
\hline $\begin{array}{l}\text { Illinois - } \\
\text { ComEd Wind } \\
\text { and PV } \\
\text { Generation } \\
\text { Program }\end{array}$ & $\begin{array}{l}40 \mathrm{~kW} \mathrm{/} \\
\text { All retail } \\
\text { customers }\end{array}$ & $\begin{array}{l}\text { Photovoltaics, } \\
\text { Wind }\end{array}$ & $\begin{array}{l}0.1 \% \text { of } \\
\text { utility's } \\
\text { annual peak } \\
\text { demand }\end{array}$ & $\begin{array}{l}\text { Purchased } \\
\text { monthly by utility } \\
\text { at avoided-cost } \\
\text { rate; customer } \\
\text { receives an } \\
\text { annual incentive } \\
\text { payment for } \\
\text { production }\end{array}$ & $\begin{array}{l}\text { (Utility } \\
\text { guidelines) }\end{array}$ & ComEd \\
\hline
\end{tabular}




\begin{tabular}{|c|c|c|c|c|c|c|}
\hline Program & $\begin{array}{c}\text { System Size } \\
\text { Limit/ } \\
\text { Customer } \\
\text { Classes } \\
\text { Eligible }\end{array}$ & \begin{tabular}{|c|} 
Eligible \\
Technologies
\end{tabular} & $\begin{array}{l}\text { Limit on } \\
\text { Total } \\
\text { Capacity }\end{array}$ & $\begin{array}{l}\text { Treatment of } \\
\text { Net Excess } \\
\text { Generation } \\
\text { (NEG) }\end{array}$ & $\begin{array}{c}\text { Interconnection } \\
\text { Standards for } \\
\text { Net Metering }\end{array}$ & $\begin{array}{l}\text { Utilities } \\
\text { Involved }\end{array}$ \\
\hline Indiana & $\begin{array}{l}10 \mathrm{~kW} / \\
\text { Residential, } \\
\text { Schools }\end{array}$ & $\begin{array}{l}\text { Photovoltaics, } \\
\text { Wind, } \\
\text { Small Hydro }\end{array}$ & \begin{tabular}{|l|}
$0.1 \%$ of a \\
utility's most \\
recent peak \\
summer load \\
\end{tabular} & \begin{tabular}{|l|}
$\begin{array}{l}\text { Credited at retail } \\
\text { rate to } \\
\text { customer's next } \\
\text { bill }\end{array}$ \\
\end{tabular} & Yes & $\begin{array}{l}\text { Investor- } \\
\text { owned } \\
\text { utilities }\end{array}$ \\
\hline lowa & $\begin{array}{l}500 \mathrm{~kW} / \\
\text { Commercial, } \\
\text { Industrial, } \\
\text { Residential }\end{array}$ & $\begin{array}{l}\text { Photovoltaics, } \\
\text { Wind, } \\
\text { Biomass, } \\
\text { Hydro, } \\
\text { Municipal } \\
\text { Solid Waste } \\
\end{array}$ & None & \begin{tabular}{|l|} 
Credited at retail \\
rate to \\
customer's next \\
bill
\end{tabular} & No & $\begin{array}{l}\text { Investor- } \\
\text { owned } \\
\text { utilities }\end{array}$ \\
\hline Kentucky & $\begin{array}{l}15 \text { kW } \\
\text { Commercial, } \\
\text { Residential, } \\
\text { Nonprofit, } \\
\text { Schools, } \\
\text { Agricultural, } \\
\text { Institutional, } \\
\text { Government } \\
\end{array}$ & Photovoltaics & \begin{tabular}{|l|}
$0.1 \%$ of a \\
utility's \\
single-hour \\
peak load \\
during the \\
previous year
\end{tabular} & $\begin{array}{l}\text { Credit at retail } \\
\text { rate to } \\
\text { customer's next } \\
\text { bill } \\
\text { (no expiration) }\end{array}$ & Yes & \begin{tabular}{|l|} 
Investor- \\
owned \\
utilities, \\
cooperatives
\end{tabular} \\
\hline Louisiana & $\begin{array}{l}100 \text { kW for } \\
\text { commercial } \\
\text { and } \\
\text { agricultural } \\
\text { systems; } 25 \\
\text { kW for } \\
\text { residential } \\
\text { systems }\end{array}$ & $\begin{array}{l}\text { Photovoltaics, } \\
\text { Wind, } \\
\text { Biomass, } \\
\text { Hydro, } \\
\text { Geothermal, } \\
\text { Fuel Cells } \\
\text { (Renewable } \\
\text { Fuels), } \\
\text { Microturbines } \\
\end{array}$ & None & \begin{tabular}{|l|} 
Credited at retail \\
rate to \\
customer's next \\
bill indefinitely
\end{tabular} & Yes & All utilities \\
\hline Maine & $\begin{array}{l}100 \mathrm{~kW} / \\
\text { Commercial, } \\
\text { Industrial, } \\
\text { Residential }\end{array}$ & $\begin{array}{l}\text { Solar, Wind, } \\
\text { Biomass, } \\
\text { Hydro, } \\
\text { Geothermal, } \\
\text { Fuel Cells, } \\
\text { Municipal } \\
\text { Solid Waste, } \\
\text { CHP, Tidal } \\
\text { Energy }\end{array}$ & None & \begin{tabular}{|l|} 
Credited at retail \\
rate to \\
customer's next \\
bill; granted to \\
utility at end of \\
12 -month billing \\
cycle
\end{tabular} & No & All utilities \\
\hline Maryland & $\begin{array}{l}200 \text { kW (500 } \\
\text { kW with } \\
\text { MD PSC } \\
\text { permission) / } \\
\text { Commercial, } \\
\text { Residential, } \\
\text { Schools, } \\
\text { Government }\end{array}$ & \begin{tabular}{|l|} 
Photovoltaics, \\
Wind, \\
Biomass
\end{tabular} & $\begin{array}{l}34.7 \mathrm{MW} \\
(0.2 \% \text { of } \\
\text { state's } \\
\text { adjusted } \\
\text { peak load in } \\
1998)\end{array}$ & $\begin{array}{l}\text { To be } \\
\text { determined by } \\
\text { MD Public } \\
\text { Service } \\
\text { Commission }\end{array}$ & Yes & All utilities \\
\hline Massachusetts & $\begin{array}{l}60 \text { kW / } \\
\text { Commercial, } \\
\text { Industrial, } \\
\text { Residential }\end{array}$ & $\begin{array}{l}\text { Renewables, } \\
\text { CHP, Fuel } \\
\text { Cells }\end{array}$ & None & \begin{tabular}{|l} 
Credited at \\
average monthly \\
market rate to \\
customer's next \\
bill
\end{tabular} & Yes & All utilities \\
\hline Michigan & $\begin{array}{l}30 \text { kW / } \\
\text { Commercial, } \\
\text { Industrial, } \\
\text { Residential, } \\
\text { Nonprofit, } \\
\text { Schools, }\end{array}$ & $\begin{array}{l}\text { Solar, Wind, } \\
\text { Biomass, } \\
\text { Hydro, } \\
\text { Geothermal, } \\
\text { Municipal } \\
\text { Solid Waste }\end{array}$ & \begin{tabular}{|l|}
$0.1 \%$ of a \\
utility's peak \\
load or 100 \\
kW \\
(whichever is \\
greater)
\end{tabular} & $\begin{array}{l}\text { Credited at retail } \\
\text { rate to } \\
\text { customer's next } \\
\text { bill; granted to } \\
\text { utility at end of } \\
12 \text {-month billing }\end{array}$ & Yes & \begin{tabular}{|l|} 
Various \\
utilities \\
(voluntary \\
participation)
\end{tabular} \\
\hline
\end{tabular}




\begin{tabular}{|c|c|c|c|c|c|c|}
\hline Program & $\begin{array}{c}\text { System Size } \\
\text { Limit/ } \\
\text { Customer } \\
\text { Classes } \\
\text { Eligible }\end{array}$ & $\begin{array}{c}\text { Eligible } \\
\text { Technologies }\end{array}$ & $\begin{array}{l}\text { Limit on } \\
\text { Total } \\
\text { Capacity }\end{array}$ & $\begin{array}{l}\text { Treatment of } \\
\text { Net Excess } \\
\text { Generation } \\
\text { (NEG) }\end{array}$ & $\begin{array}{l}\text { Interconnection } \\
\text { Standards for } \\
\text { Net Metering }\end{array}$ & $\begin{array}{l}\text { Utilities } \\
\text { Involved }\end{array}$ \\
\hline & $\begin{array}{l}\text { Government, } \\
\text { Agricultural, } \\
\text { Institutional }\end{array}$ & & & cycle & & \\
\hline Minnesota & $\begin{array}{l}40 \mathrm{~kW} / \\
\text { Commercial, } \\
\text { Industrial, } \\
\text { Residential }\end{array}$ & $\begin{array}{l}\text { Photovoltaics, } \\
\text { Wind, } \\
\text { Biomass, } \\
\text { Hydro, } \\
\text { Municipal } \\
\text { Solid Waste, } \\
\text { CHP }\end{array}$ & None & $\begin{array}{l}\text { Purchased at } \\
\text { average retail } \\
\text { utility energy } \\
\text { rate }\end{array}$ & Yes & All utilities \\
\hline Montana & $\begin{array}{l}50 \mathrm{~kW} / \\
\text { Commercial, } \\
\text { Industrial, } \\
\text { Residential }\end{array}$ & $\begin{array}{l}\text { Photovoltaics, } \\
\text { Wind, Hydro }\end{array}$ & None & $\begin{array}{l}\text { Credited at retail } \\
\text { rate to } \\
\text { customer's next } \\
\text { bill; granted to } \\
\text { utility at end of } \\
12-\text { month billing } \\
\text { cycle }\end{array}$ & Yes & $\begin{array}{l}\text { Investor- } \\
\text { owned } \\
\text { utilities }\end{array}$ \\
\hline $\begin{array}{l}\text { Montana - } \\
\text { Montana } \\
\text { Electric } \\
\text { Cooperatives }\end{array}$ & $\begin{array}{l}10 \mathrm{~kW} / \\
\text { Commercial, } \\
\text { Residential }\end{array}$ & $\begin{array}{l}\text { Photovoltaics, } \\
\text { Wind, } \\
\text { Geothermal, } \\
\text { Fuel Cells, } \\
\text { Small Hydro }\end{array}$ & None & $\begin{array}{l}\text { Credited at retail } \\
\text { rate to } \\
\text { customer's next } \\
\text { bill; granted to } \\
\text { utility at end of } \\
12-\text { month billing } \\
\text { cycle }\end{array}$ & Yes & $\begin{array}{l}\text { Most of } \\
\text { MEC's } 26 \\
\text { member } \\
\text { cooperatives }\end{array}$ \\
\hline Nevada & $\begin{array}{l}150 \mathrm{~kW}^{2} \text { / } \\
\text { Commercial, } \\
\text { Industrial, } \\
\text { Residential }\end{array}$ & $\begin{array}{l}\text { Solar, Wind, } \\
\text { Biomass, } \\
\text { Hydro, } \\
\text { Geothermal }\end{array}$ & $\begin{array}{l}1 \% \text { of a } \\
\text { utility's peak } \\
\text { capacity }\end{array}$ & \begin{tabular}{|l} 
Credited at retail \\
rate to \\
customer's next \\
bill; \\
no expiration ${ }^{3}$ \\
\end{tabular} & Yes & $\begin{array}{l}\text { Investor- } \\
\text { owned } \\
\text { utilities }\end{array}$ \\
\hline $\begin{array}{l}\text { New } \\
\text { Hampshire }\end{array}$ & $\begin{array}{l}25 \text { kW / } \\
\text { Commercial, } \\
\text { Industrial, } \\
\text { Residential }\end{array}$ & $\begin{array}{l}\text { Photovoltaics, } \\
\text { Wind, Hydro }\end{array}$ & $\begin{array}{l}0.05 \% \text { of a } \\
\text { utility's peak } \\
\text { demand }\end{array}$ & $\begin{array}{l}\text { Credited at retail } \\
\text { rate to } \\
\text { customer's next } \\
\text { bill }\end{array}$ & Yes & All utilities \\
\hline New Jersey & $\begin{array}{l}2 \mathrm{MW} / \\
\text { Commercial, } \\
\text { Residential }\end{array}$ & \begin{tabular}{|l} 
Solar, Wind, \\
Biomass, \\
Hydro, \\
Geothermal, \\
Fuel Cells \\
(Renewable \\
Fuels), Tidal \\
Energy, Wave \\
Energy \\
\end{tabular} & None & \begin{tabular}{|l} 
Credited at retail \\
rate to \\
customer's next \\
bill; purchased \\
by utility at \\
avoided-cost \\
rate at end of \\
$12-$ month billing \\
cycle
\end{tabular} & Yes & All utilities \\
\hline New Mexico & $\begin{array}{l}10 \text { kW / } \\
\text { Commercial, } \\
\text { Industrial, } \\
\text { Residential }\end{array}$ & $\begin{array}{l}\text { Solar, Wind, } \\
\text { Biomass, } \\
\text { Hydro, } \\
\text { Geothermal, } \\
\text { Fuel Cells, } \\
\text { Municipal } \\
\text { Solid Waste, }\end{array}$ & None & $\begin{array}{l}\text { Credited to } \\
\text { customer's next } \\
\text { bill or purchased } \\
\text { by utility at } \\
\text { avoided-cost } \\
\text { rate }\end{array}$ & Yes & $\begin{array}{l}\text { Investor- } \\
\text { owned } \\
\text { utilities, } \\
\text { cooperatives }\end{array}$ \\
\hline
\end{tabular}

${ }^{2}$ In Nevada, utilities are permitted to require customers with systems of more than $30 \mathrm{~kW}$ in capacity to install a second meter at the customer's expense.

${ }^{3}$ In Nevada, it is unclear how NEG is treated for systems of more than $30 \mathrm{~kW}$ in capacity. 


\begin{tabular}{|c|c|c|c|c|c|c|}
\hline Program & \begin{tabular}{|c|} 
System Size \\
Limit/ \\
Customer \\
Classes \\
Eligible
\end{tabular} & $\begin{array}{c}\text { Eligible } \\
\text { Technologies }\end{array}$ & $\begin{array}{l}\text { Limit on } \\
\text { Total } \\
\text { Capacity }\end{array}$ & $\begin{array}{l}\text { Treatment of } \\
\text { Net Excess } \\
\text { Generation } \\
\text { (NEG) }\end{array}$ & $\begin{array}{l}\text { Interconnection } \\
\text { Standards for } \\
\text { Net Metering }\end{array}$ & $\begin{array}{l}\text { Utilities } \\
\text { Involved }\end{array}$ \\
\hline & & $\begin{array}{l}\text { CHP, } \\
\text { Microturbines }\end{array}$ & & & & \\
\hline New York & $\begin{array}{l}400 \mathrm{~kW} \text { for } \\
\text { farm waste; } \\
125 \mathrm{~kW} \text { for } \\
\text { farm-based } \\
\text { wind; } 25 \mathrm{~kW} \\
\text { for residential } \\
\text { wind; } 10 \mathrm{~kW} \\
\text { for solar }\end{array}$ & $\begin{array}{l}\text { Photovoltaics, } \\
\text { Biomass, } \\
\text { Wind }\end{array}$ & $\begin{array}{l}\text { Solar: } 0.1 \% \\
\text { of a utility's } \\
\text { demand in } \\
1996 ; \text { farm } \\
\text { biogas: } 0.4 \% \\
\text { of a utility's } \\
\text { demand in } \\
1996 ; \text { wind: } \\
0.2 \% \text { of a } \\
\text { utility's } 2003 \\
\text { demand }\end{array}$ & \begin{tabular}{|l} 
Credited to \\
customer's next \\
bill - except \\
NEG from wind \\
systems over 10 \\
$\mathrm{~kW}$, which is \\
credited to \\
customer's next \\
bill at the utility's \\
avoided-cost \\
rate. All NEG \\
purchased by \\
utility at avoided- \\
cost rate at end \\
of $12-$ month \\
billing cycle.
\end{tabular} & Yes & All utilities \\
\hline North Carolina & $\begin{array}{l}20 \mathrm{~kW} \\
\text { residential; } \\
100 \mathrm{~kW} \text { non- } \\
\text { residential }\end{array}$ & $\begin{array}{l}\text { Photovoltaics, } \\
\text { Wind, } \\
\text { Biomass }\end{array}$ & $\begin{array}{l}0.2 \% \text { of a } \\
\text { utility's North } \\
\text { Carolina } \\
\text { retail peak } \\
\text { load for the } \\
\text { previous year }\end{array}$ & $\begin{array}{l}\text { Credited at retail } \\
\text { rate to } \\
\text { customer's next } \\
\text { monthly bill; } \\
\text { granted to utility } \\
\text { every June } 1 \\
\text { and October } 1\end{array}$ & Yes & $\begin{array}{l}\text { Investor- } \\
\text { owned } \\
\text { utilities }\end{array}$ \\
\hline North Dakota & $\begin{array}{l}100 \text { kW / } \\
\text { Commercial, } \\
\text { Industrial, } \\
\text { Residential }\end{array}$ & $\begin{array}{l}\text { Solar, Wind, } \\
\text { Biomass, } \\
\text { Hydro, } \\
\text { Geothermal, } \\
\text { Municipal } \\
\text { Solid Waste, } \\
\text { CHP }\end{array}$ & None & $\begin{array}{l}\text { Purchased by } \\
\text { utility at avoided- } \\
\text { cost rate }\end{array}$ & No & $\begin{array}{l}\text { Investor- } \\
\text { owned } \\
\text { utilities }\end{array}$ \\
\hline Ohio & $\begin{array}{l}100 \mathrm{~kW} \text { for } \\
\text { microturbines; } \\
\text { no limit for } \\
\text { other systems } \\
/ \\
\text { Commercial, } \\
\text { Industrial, } \\
\text { Residential } \\
\end{array}$ & $\begin{array}{l}\text { Solar, Wind, } \\
\text { Biomass, } \\
\text { Hydro, } \\
\text { Fuel Cells, } \\
\text { Microturbines }\end{array}$ & $\begin{array}{l}1 \% \text { of a } \\
\text { utility's peak } \\
\text { demand }\end{array}$ & \begin{tabular}{|l} 
Credited at \\
utility's \\
unbundled- \\
generation rate \\
to customer's \\
next monthly bill
\end{tabular} & Yes & $\begin{array}{l}\text { All } \\
\text { competitive } \\
\text { utilities }\end{array}$ \\
\hline $\begin{array}{l}\text { Ohio - } \\
\text { Bowling } \\
\text { Green } \\
\text { Municipal } \\
\text { Utilities } \\
\end{array}$ & $\begin{array}{l}25 \text { kW / } \\
\text { Commercial, } \\
\text { Residential }\end{array}$ & $\begin{array}{l}\text { Photovoltaics, } \\
\text { Wind, Hydro, } \\
\text { Fuel Cells }\end{array}$ & None & $\begin{array}{l}\text { Negotiated with } \\
\text { utility }\end{array}$ & $\begin{array}{l}\text { (Utility } \\
\text { guidelines) }\end{array}$ & $\begin{array}{l}\text { Bowling } \\
\text { Green } \\
\text { Municipal } \\
\text { Utilities }\end{array}$ \\
\hline Oklahoma & $\begin{array}{l}100 \mathrm{~kW} \text { or } \\
25,000 \\
\text { kWh/year } \\
\text { (whichever is } \\
\text { less) / } \\
\text { Commercial, } \\
\text { Industrial, } \\
\text { Residential }\end{array}$ & $\begin{array}{l}\text { Solar, Wind, } \\
\text { Biomass, } \\
\text { Hydro, } \\
\text { Geothermal, } \\
\text { Municipal } \\
\text { Solid Waste, } \\
\text { CHP }\end{array}$ & None & $\begin{array}{l}\text { Granted to utility } \\
\text { monthly or } \\
\text { credited to } \\
\text { customer's next } \\
\text { bill at utility's } \\
\text { avoided-cost } \\
\text { rate (varies by } \\
\text { utility) }\end{array}$ & No & All utilities \\
\hline Oregon & $\begin{array}{l}25 \mathrm{~kW} / \\
\text { Commercial, }\end{array}$ & $\begin{array}{l}\text { Solar, Wind, } \\
\text { Hydro, Fuel }\end{array}$ & $\begin{array}{l}0.5 \% \text { of a } \\
\text { utility's }\end{array}$ & $\begin{array}{l}\text { Credited at retail } \\
\text { rate to }\end{array}$ & Yes & All utilities \\
\hline
\end{tabular}




\begin{tabular}{|c|c|c|c|c|c|c|}
\hline Program & \begin{tabular}{|c|} 
System Size \\
Limit/ \\
Customer \\
Classes \\
Eligible
\end{tabular} & $\begin{array}{c}\text { Eligible } \\
\text { Technologies }\end{array}$ & $\begin{array}{l}\text { Limit on } \\
\text { Total } \\
\text { Capacity }\end{array}$ & $\begin{array}{l}\text { Treatment of } \\
\text { Net Excess } \\
\text { Generation } \\
\text { (NEG) }\end{array}$ & $\begin{array}{l}\text { Interconnection } \\
\text { Standards for } \\
\text { Net Metering }\end{array}$ & $\begin{array}{l}\text { Utilities } \\
\text { Involved }\end{array}$ \\
\hline & $\begin{array}{l}\text { Industrial, } \\
\text { Residential }\end{array}$ & Cells & $\begin{array}{l}\text { historic } \\
\text { single-hour } \\
\text { peak load }\end{array}$ & $\begin{array}{l}\text { customer's next } \\
\text { bill or purchased } \\
\text { by utility at } \\
\text { avoided-cost } \\
\text { rate }\end{array}$ & & \\
\hline $\begin{array}{l}\text { Oregon - } \\
\text { Ashland } \\
\text { Electric }\end{array}$ & $\begin{array}{l}\text { None / } \\
\text { Commercial, } \\
\text { Residential }\end{array}$ & $\begin{array}{l}\text { Photovoltaics, } \\
\text { Wind }\end{array}$ & None & $\begin{array}{l}\text { Purchased by } \\
\text { utility monthly at } \\
\text { retail rate } \\
(1,000 \\
\text { kWh/month } \\
\text { maximum) }\end{array}$ & $\begin{array}{l}\text { (Utility } \\
\text { guidelines) }\end{array}$ & $\begin{array}{l}\text { Ashland } \\
\text { Electric }\end{array}$ \\
\hline $\begin{array}{l}\text { Pennsylvania } \\
\text { (new rules } \\
\text { under } \\
\text { development) }\end{array}$ & $\begin{array}{l}\text { Varies by } \\
\text { utility / } \\
\text { Commercial, } \\
\text { Industrial, } \\
\text { Residential }\end{array}$ & $\begin{array}{l}\text { Solar, Wind, } \\
\text { Biomass, } \\
\text { Hydro }\end{array}$ & $\begin{array}{l}\text { Varies by } \\
\text { utility }\end{array}$ & $\begin{array}{l}\text { Varies by utility } \\
\text { (granted to utility } \\
\text { in most cases) }\end{array}$ & Varies by utility & All utilities \\
\hline Rhode Island & $\begin{array}{l}25 \mathrm{~kW} / \\
\text { Commercial, } \\
\text { Industrial, } \\
\text { Residential }\end{array}$ & $\begin{array}{l}\text { Solar, Wind, } \\
\text { Biomass, } \\
\text { Hydro, } \\
\text { Geothermal, } \\
\text { Fuel Cells, } \\
\text { Municipal } \\
\text { Solid Waste, } \\
\text { CHP }\end{array}$ & \begin{tabular}{|l|}
$1 \mathrm{MW}$ \\
(Narragansett \\
territory)
\end{tabular} & $\begin{array}{l}\text { Credited at retail } \\
\text { rate to } \\
\text { customer's next } \\
\text { bill; granted to } \\
\text { utility at end of } \\
12-\text { month billing } \\
\text { cycle }\end{array}$ & No & $\begin{array}{l}\text { Narragansett } \\
\text { Electric }\end{array}$ \\
\hline Texas & $\begin{array}{l}50 \text { kW / } \\
\text { Commercial, } \\
\text { Industrial, } \\
\text { Residential }\end{array}$ & $\begin{array}{l}\text { Solar, Wind, } \\
\text { Biomass, } \\
\text { Hydro, } \\
\text { Geothermal, } \\
\text { Fuel Cells, } \\
\text { Tidal Energy, } \\
\text { Wave Energy, } \\
\text { Microturbines }\end{array}$ & None & $\begin{array}{l}\text { Purchased by } \\
\text { utility monthly at } \\
\text { avoided-cost } \\
\text { rate }\end{array}$ & Yes & $\begin{array}{l}\text { Most non- } \\
\text { municipal } \\
\text { utilities and } \\
\text { non- } \\
\text { cooperatives }\end{array}$ \\
\hline \begin{tabular}{|l|} 
Texas - \\
San Antonio \\
City Public \\
Service
\end{tabular} & $\begin{array}{l}25 \text { kW / } \\
\text { Commercial, } \\
\text { Residential }\end{array}$ & $\begin{array}{l}\text { Photovoltaics, } \\
\text { Wind, } \\
\text { Biomass, } \\
\text { Hydro, } \\
\text { Geothermal, } \\
\text { Tidal Energy, } \\
\text { Wave Energy }\end{array}$ & None & $\begin{array}{l}\text { Credited at retail } \\
\text { rate to } \\
\text { customer's next } \\
\text { bill at utility's } \\
\text { seasonal } \\
\text { avoided-cost } \\
\text { rate }\end{array}$ & $\begin{array}{l}\text { (Utility } \\
\text { guidelines) }\end{array}$ & $\begin{array}{l}\text { San Antonio } \\
\text { City Public } \\
\text { Service }\end{array}$ \\
\hline $\begin{array}{l}\text { Texas - } \\
\text { Austin Energy }\end{array}$ & $\begin{array}{l}20 \text { kW / } \\
\text { Commercial, } \\
\text { Residential }\end{array}$ & $\begin{array}{l}\text { Solar, Wind, } \\
\text { Biomass, } \\
\text { Hydro, } \\
\text { Geothermal, } \\
\text { Municipal } \\
\text { Solid Waste }\end{array}$ & $\begin{array}{l}1 \% \text { of utility's } \\
\text { load }\end{array}$ & $\begin{array}{l}\text { Credited to } \\
\text { customer's next } \\
\text { bill }\end{array}$ & $\begin{array}{l}\text { (Utility } \\
\text { guidelines) }\end{array}$ & $\begin{array}{l}\text { Austin } \\
\text { Energy }\end{array}$ \\
\hline Utah & $\begin{array}{l}25 \mathrm{~kW} / \\
\text { Commercial, } \\
\text { Industrial, } \\
\text { Residential }\end{array}$ & $\begin{array}{l}\text { Solar, Wind, } \\
\text { Hydro, } \\
\text { Fuel Cells }\end{array}$ & \begin{tabular}{|l|}
$0.1 \%$ of a \\
utility's 2001 \\
peak demand
\end{tabular} & $\begin{array}{l}\text { Credited at retail } \\
\text { rate to } \\
\text { customer's next } \\
\text { bill; granted to } \\
\text { utility at end of } \\
12-\text { month billing } \\
\text { cycle }\end{array}$ & Yes & $\begin{array}{l}\text { Investor- } \\
\text { owned } \\
\text { utilities, } \\
\text { cooperatives }\end{array}$ \\
\hline Vermont & $\begin{array}{l}150 \mathrm{~kW} \text { for } \\
\text { farm systems; } \\
15 \mathrm{~kW} \text { for }\end{array}$ & \begin{tabular}{|l} 
Photovoltaics, \\
Wind, \\
Biomass, Fuel
\end{tabular} & \begin{tabular}{|l|}
$\%$ of a \\
utility's 1996 \\
peak demand
\end{tabular} & $\begin{array}{l}\text { Credited at retail } \\
\text { rate to } \\
\text { customer's next }\end{array}$ & Yes & All utilities \\
\hline
\end{tabular}




\begin{tabular}{|c|c|c|c|c|c|c|}
\hline Program & $\begin{array}{c}\text { System Size } \\
\text { Limit/ } \\
\text { Customer } \\
\text { Classes } \\
\text { Eligible }\end{array}$ & $\begin{array}{c}\text { Eligible } \\
\text { Technologies }\end{array}$ & $\begin{array}{l}\text { Limit on } \\
\text { Total } \\
\text { Capacity }\end{array}$ & $\begin{array}{l}\text { Treatment of } \\
\text { Net Excess } \\
\text { Generation } \\
\text { (NEG) }\end{array}$ & $\begin{array}{l}\text { Interconnection } \\
\text { Standards for } \\
\text { Net Metering }\end{array}$ & $\begin{array}{l}\text { Utilities } \\
\text { Involved }\end{array}$ \\
\hline & $\begin{array}{l}\text { commercial } \\
\text { and } \\
\text { residential / } \\
\text { Commercial, } \\
\text { Residential, } \\
\text { Agricultural }\end{array}$ & Cells & $\begin{array}{l}\text { or peak } \\
\text { demand } \\
\text { during most } \\
\text { recent } \\
\text { calendar year } \\
\text { (whichever is } \\
\text { less) }\end{array}$ & $\begin{array}{l}\text { bill; granted to } \\
\text { utility at end of } \\
12-\text { month billing } \\
\text { cycle }\end{array}$ & & \\
\hline Virginia & $\begin{array}{l}500 \mathrm{~kW} \text { for } \\
\text { non- } \\
\text { residential; } \\
10 \mathrm{~kW} \text { for } \\
\text { residential / } \\
\text { Commercial, } \\
\text { Residential, } \\
\text { Nonprofit, } \\
\text { Schools, } \\
\text { Government, } \\
\text { Institutional }\end{array}$ & $\begin{array}{l}\text { Solar, Wind, } \\
\text { Hydro }\end{array}$ & \begin{tabular}{|l}
$0.1 \%$ of a \\
utility's \\
annual peak \\
demand
\end{tabular} & $\begin{array}{l}\text { Credited at retail } \\
\text { rate to } \\
\text { customer's next } \\
\text { bill; granted to } \\
\text { utility at end of } \\
12-\text { month billing } \\
\text { cycle }\end{array}$ & Yes & All utilities \\
\hline Washington & $\begin{array}{l}25 \mathrm{~kW} / \\
\text { Commercial, } \\
\text { Industrial, } \\
\text { Residential }\end{array}$ & $\begin{array}{l}\text { Solar, Wind, } \\
\text { Hydro, } \\
\text { Fuel Cells }\end{array}$ & $\begin{array}{l}0.1 \% \text { of a } \\
\text { utility's } 1996 \\
\text { peak load }\end{array}$ & $\begin{array}{l}\text { Credited at retail } \\
\text { rate to } \\
\text { customer's next } \\
\text { bill; granted to } \\
\text { utility at end of } \\
12-\text { month billing } \\
\text { cycle }\end{array}$ & Yes & All utilities \\
\hline $\begin{array}{l}\text { Washington - } \\
\text { Grays Harbor } \\
\text { PUD }\end{array}$ & $\begin{array}{l}25 \mathrm{~kW} / \\
\text { Commercial, } \\
\text { Industrial, } \\
\text { Residential }\end{array}$ & $\begin{array}{l}\text { Solar, Wind, } \\
\text { Hydro, } \\
\text { Fuel Cells }\end{array}$ & $\begin{array}{l}0.1 \% \text { of } \\
\text { utility's } 1996 \\
\text { peak load }\end{array}$ & \begin{tabular}{|l} 
Purchased by \\
utility annually at \\
$50 \%$ of \\
retail rate
\end{tabular} & Yes & $\begin{array}{l}\text { Grays } \\
\text { Harbor PUD }\end{array}$ \\
\hline Wisconsin & $\begin{array}{l}20 \text { kW / } \\
\text { Commercial, } \\
\text { Industrial, } \\
\text { Residential }\end{array}$ & $\begin{array}{l}\text { Solar, Wind, } \\
\text { Biomass, } \\
\text { Hydro, } \\
\text { Geothermal, } \\
\text { Municipal } \\
\text { Solid Waste, } \\
\text { CHP }\end{array}$ & None & $\begin{array}{l}\text { Purchased by } \\
\text { utility at retail } \\
\text { rate } \\
\text { (renewables) or } \\
\text { avoided-cost } \\
\text { rate (non- } \\
\text { renewables) }\end{array}$ & Yes & $\begin{array}{l}\text { Investor- } \\
\text { owned } \\
\text { utilities }\end{array}$ \\
\hline Wyoming & $\begin{array}{l}25 \mathrm{~kW} / \\
\text { Commercial, } \\
\text { Industrial, } \\
\text { Residential }\end{array}$ & $\begin{array}{l}\text { Solar, Wind, } \\
\text { Biomass, } \\
\text { Hydro }\end{array}$ & None & $\begin{array}{l}\text { Credited at retail } \\
\text { rate to } \\
\text { customer's next } \\
\text { bill; purchased } \\
\text { by utility at } \\
\text { avoided-cost } \\
\text { rate at end of } \\
12-\text { month billing } \\
\text { cycle }\end{array}$ & Yes & All utilities \\
\hline
\end{tabular}

Sources: The Interstate Renewable Energy Council (IREC) and the N.C. Solar Center (NCSC).

"Connecting to the Grid" Project Web site, http://www.irecusa.org/connect; Database of State Incentives for Renewable Energy (DSIRE), http://www.dsireusa.org, March 2006. Additional information, including most legislative and regulatory source citations, is available via DSIRE. 


\section{5 - States with Environmental Disclosure Policies}

As electricity markets open to competition, retail consumers are increasingly gaining the ability to choose their electricity suppliers. With this choice comes the need for consumers to have access to information about the price, source, and environmental characteristics of their electricity. For green power marketers, in particular, it is important that consumers understand the environmental implications of their energy consumption decisions. To date, 25 states and the District of Columbia have environmental disclosure policies in place (Figure 3.5.1), requiring electricity suppliers to provide information on fuel sources and, in some cases, emissions associated with electricity generation. Although most of these policies have been adopted in states with retail competition, a handful of states with no plans to implement restructuring have required environmental disclosure.

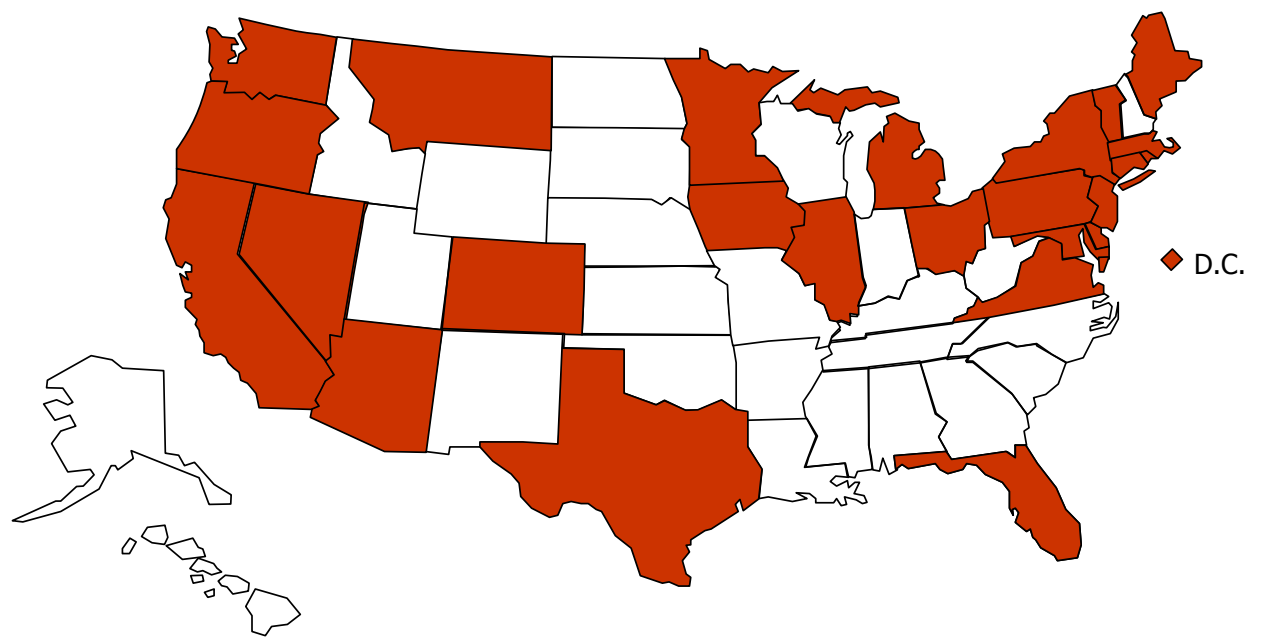

State has a Disclosure Rule

Source: DSIRE database, January 2006.

http://www.dsireusa.org/index.cfm?\&CurrentPagelD=10

Figure 3.5.1: Environmental Disclosure Requirements by State 


\section{6 - Green Power Markets}

There are three distinct markets for green power in the United States. In regulated markets, a single utility may provide a green power option to its customers through "green pricing," which is an optional service or tariff offered to customers. These utilities include investor-owned utilities, rural electric cooperatives, and other publicly owned utilities. More than 600 utilities in 34 states offer green pricing, or are in the process of preparing programs.

In restructured (or competitive) electricity markets, retail electricity customers can choose from among multiple electricity suppliers, some of which may offer green power. Electricity markets are now open to full competition in a number of states, while others are phasing in competition.

Finally, consumers can purchase green power through "renewable energy certificates." These certificates represent the environmental attributes of renewable energy generation and can be sold to customers in either type of market, whether or not they already have access to a green power product from their existing retail power provider.

Utility market research shows that majorities of customer respondents are likely to state that they would pay at least $\$ 5$ more per month for renewable energy. And business and other nonresidential customers, including colleges and universities, and government entities are increasingly interested in green power.

\section{Customers}

At the end of 2004, more than 500,000 electricity customers nationally were purchasing green power products through regulated utility companies, from green power marketers in a competitive market setting, or in the form of RECs (Table 3.6.1). In aggregate, utility green pricing programs have shown steady growth in customers over time as the number of utility programs has increased and as existing programs have grown. On the other hand, competitive markets have been less consistent. While green power sales have grown in Texas and some Northeast states, other markets have failed altogether-most notably in California and Connecticut. While REC customers represent a small fraction of the total customer base, REC sales have increased dramatically because of a number of very large purchases.

Average participation rates among utility green pricing programs have remained steady at just more than $1 \%$, although the top performing utility green pricing programs have achieved rates ranging from $4 \%$ to $15 \%$. Competitive markets have experienced penetration rates of from $1 \%$ to $2 \%$ in states where the market has been conducive to retail competition. 
Table 3.6.1: Estimated Green Power Customers by Market Segment

\begin{tabular}{|l|r|r|r|r|r|}
\hline & \multicolumn{1}{|c|}{$\mathbf{2 0 0 0}$} & \multicolumn{1}{c|}{$\mathbf{2 0 0 1}$} & $\mathbf{2 0 0 2}$ & $\mathbf{2 0 0 3}$ & $\mathbf{2 0 0 4}$ \\
\hline Utility Green Pricing & $130,000^{*}$ & $170,000^{*}$ & $230,000^{*}$ & 270,000 & 330,000 \\
\hline Competitive Markets & $>160,000^{* *}$ & $>110,000^{* *}$ & $\sim 150,000$ & $>150,000$ & $>180,000$ \\
\hline REC Markets & -- & -- & $<10,000$ & $<10,000$ & $<10,000$ \\
\hline Retail Total & $>290,000$ & $>280,000$ & $\sim 390,000$ & $\sim 430,000$ & $\sim 520,000$ \\
\hline
\end{tabular}

* Annual program participant numbers have been adjusted downward from those originally reported in Bird and Swezey (2003), because of program participation revisions made by the Los Angeles Department of Water and Power.

** Includes only customers purchasing Green-e certified green power products, as reported by the Center for Resource Solutions (2001; 2002).

\section{Sales}

Retail sales of renewable energy in voluntary purchase markets experienced strong growth in 2004, increasing more than $60 \%$ to 6.2 billion $\mathrm{kWh}$ annually. This includes sales of renewable energy derived from both new and preexisting renewable energy sources. REC sales nearly tripled, while sales through utility green pricing programs and competitive marketers also exhibited strong annual growth of about $40 \%$.

Table 3.6.2: Estimated Green Power Sales by Market Segment (million kWh)

\begin{tabular}{|l|r|r|r|}
\hline & \multicolumn{1}{|c|}{$\mathbf{2 0 0 3}$} & \multicolumn{1}{c|}{$\mathbf{2 0 0 4}$} & \multicolumn{1}{c|}{ Increase } \\
\hline Utility Green Pricing & 1,280 & 1,840 & $43 \%$ \\
\hline Competitive Markets & 1,900 & 2,650 & $40 \%$ \\
\hline REC Markets & 660 & 1,720 & $162 \%$ \\
\hline Retail Total & 3,840 & 6,210 & $62 \%$ \\
\hline
\end{tabular}

*Includes sales of new and existing renewable energy.

Purchases by residential customers represent slightly more than half of total renewable energy sales in voluntary markets. In 2004, nonresidential customers accounted for 30\% and $20 \%$ of total renewable energy sales in green pricing programs and competitive markets, respectively, and nearly all REC sales.

Since 2000 , the amount of renewable energy capacity serving green power markets has increased more than tenfold. At the end of 2004, more than 2,200 MW of new renewable energy generation capacity was being used to supply green power markets, with another $450 \mathrm{MW}$ planned. 
Table 3.6.3: Estimated Green Power Sales by Customer Segment, 2004 (million kWh)

\begin{tabular}{|l|r|r|r|r|r|}
\hline & \multicolumn{1}{|c|}{$\begin{array}{c}\text { Green } \\
\text { Pricing }\end{array}$} & \multicolumn{1}{c|}{$\begin{array}{c}\text { Competitive } \\
\text { Markets }\end{array}$} & $\begin{array}{c}\text { REC } \\
\text { Markets }\end{array}$ & Total & Share \\
\hline Residential & 1,300 & 2,140 & 40 & 3,480 & $56 \%$ \\
\hline Nonresidential & 540 & 510 & 1,690 & 2,740 & $44 \%$ \\
\hline Total & 1,840 & 2,650 & 1,720 & 6,210 & $100 \%$ \\
\hline
\end{tabular}

Totals may not add due to rounding.

Table 3.6.4: Estimated New Renewables Capacity Supplying Green Power Markets, 2000-2004 (megawatts)

\begin{tabular}{|c|c|c|c|c|c|}
\hline Market & 2000 & 2001 & 2002 & 2003 & 2004 \\
\hline Utility Green Pricing & 77 & 221 & 279 & 510 & 706 \\
\hline Competitive Markets/RECs & 90 & 542 & 695 & 1,126 & 1,528 \\
\hline Total & 167 & 764 & 974 & 1,636 & 2,233 \\
\hline
\end{tabular}

Totals may not add due to rounding.

Source: Bird and Swezey (2005).

Table 3.6.5: New Renewables Capacity Supplying Green Power Markets, 2004

\begin{tabular}{|l|c|l|l|l|}
\hline \multicolumn{1}{|c|}{ Source } & MW in Place & \multicolumn{1}{c|}{ \% } & MW Planned & \% \\
\hline Wind & $2,045.6$ & 91.6 & 364.5 & 80.1 \\
\hline Biomass & 135.6 & 6.1 & 58.8 & 12.9 \\
\hline Solar & 8.1 & 0.4 & 0.4 & 0.1 \\
\hline Geothermal & 35.5 & 1.6 & 0.0 & 0.0 \\
\hline Small Hydro & 8.5 & 0.4 & 31.3 & 6.9 \\
\hline Total & $2,233.3$ & 100.0 & 455.0 & 100.0 \\
\hline
\end{tabular}

Source: L.Bird and B. Swezey, Estimates of New Renewable Energy Capacity

Serving U.S. Green Power Markets (2004), National Renewable Energy Laboratory, September 2005.

http://www.eere.energy.gov/greenpower/resources/tables/new_gp_cap.shtml 


\section{7 - States with Utility Green Pricing Programs}

Green pricing is an optional utility service that allows customers an opportunity to support a greater level of utility company investment in renewable energy technologies. Participating customers pay a premium on their electric bill to cover the extra cost of the renewable energy. Many utilities are offering green pricing to build customer loyalty and expand business lines and expertise prior to electric market competition. To date, more than 600 investor-owned, municipal, and cooperative utilities in 34 states have either implemented or announced plans to offer a green pricing option (Figure 3.7.1).

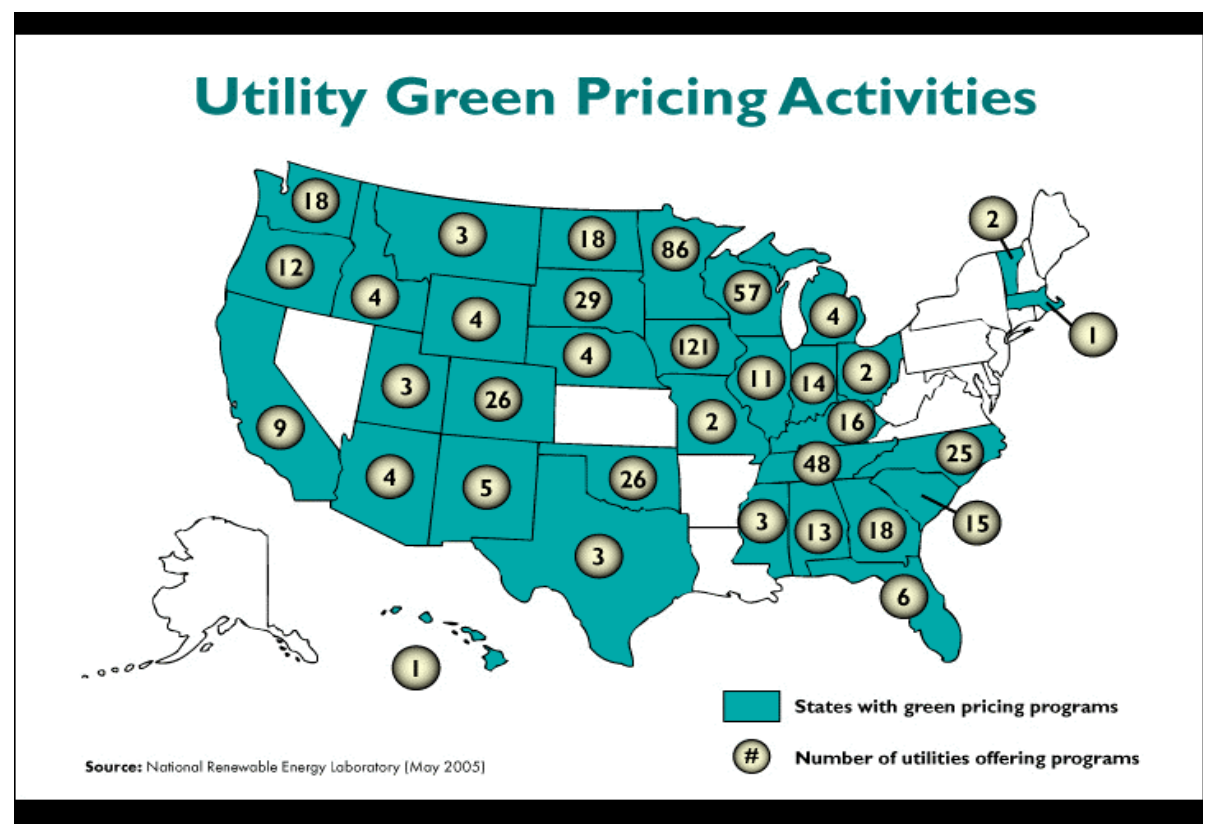

Source: L. Bird and B. Swezey, National Renewable Energy Laboratory. Updated May 2005. http://www.eere.energy.gov/greenpower/markets/pricing.shtml?page=4

Figure 3.7.1: Number of Utilities Offering Green Pricing Programs by State 
Table 3.7.1: New Renewable Energy Capacity Supplying Green Pricing Programs in 2004 (megawatts)

\begin{tabular}{|l|l|l|l|l|}
\hline \multicolumn{1}{|c|}{ Source } & \multicolumn{2}{c|}{ Installed } & \multicolumn{2}{c|}{ Planned } \\
\hline Wind & 584.0 & $82.8 \%$ & 139.7 & $61.1 \%$ \\
\hline Biomass & 76.3 & $10.8 \%$ & 57.5 & $25.1 \%$ \\
\hline Solar & 6.1 & $0.9 \%$ & 0.2 & $0.1 \%$ \\
\hline Geothermal & 30.5 & $4.3 \%$ & 0.0 & $0.0 \%$ \\
\hline Small Hydro & 8.5 & $1.2 \%$ & 31.3 & $13.7 \%$ \\
\hline Total & 705.5 & $100.0 \%$ & 228.7 & $100.0 \%$ \\
\hline
\end{tabular}

Source: Bird and Brown (2005)

Table 3.7.2: Estimated Cumulative Number of Customers Participating in Utility Green Pricing Programs

\begin{tabular}{|l|r|r|r|r|r|r|}
\hline \multicolumn{1}{|c|}{ Customer Segment } & \multicolumn{1}{c|}{1999} & \multicolumn{1}{c|}{$\mathbf{2 0 0 0}$} & \multicolumn{1}{c|}{$\mathbf{2 0 0 1}$} & \multicolumn{1}{c|}{$\mathbf{2 0 0 2}$} & \multicolumn{1}{c|}{$\mathbf{2 0 0 3}$} & $\mathbf{2 0 0 4}$ \\
\hline Residential & $\mathrm{na}^{*}$ & 131,000 & 166,300 & 224,500 & 258,700 & 323,700 \\
\hline Nonresidential & $\mathrm{na}^{*}$ & 1,700 & 2,500 & 3,900 & 6,500 & 8,100 \\
\hline Total & 66,900 & 132,700 & 168,800 & 228,400 & 265,000 & 331,800 \\
\hline$\%$ Annual Growth & na & $98 \%$ & $27 \%$ & $35 \%$ & $16 \%$ & $25 \%$ \\
\hline$\%$ Nonresidential & na & $1.3 \%$ & $1.5 \%$ & $1.7 \%$ & $2.4 \%$ & $2.5 \%$ \\
\hline
\end{tabular}

*Information on residential and nonresidential participants is not available for 1999.

Source: Bird and Brown (2005)

Table 3.7.3: Customer Participation Rates in Utility Green Pricing Programs by Year

\begin{tabular}{|l|l|l|l|l|l|l|}
\hline & \multicolumn{1}{|c|}{$\mathbf{1 9 9 9}$} & \multicolumn{1}{|c|}{$\mathbf{2 0 0 0}$} & \multicolumn{1}{|c|}{$\mathbf{2 0 0 1}$} & \multicolumn{1}{|c|}{$\mathbf{2 0 0 2}$} & $\mathbf{2 0 0 3}$ & $\mathbf{2 0 0 4}$ \\
\hline Average & $0.9 \%$ & $1.2 \%$ & $1.3 \%$ & $1.2 \%$ & $1.2 \%$ & $1.3 \%$ \\
\hline Median & $0.8 \%$ & $0.7 \%$ & $0.7 \%$ & $0.8 \%$ & $0.9 \%$ & $1.0 \%$ \\
\hline $\begin{array}{l}\text { Top } 10 \\
\text { programs } \\
\text { for } \\
\text { participation } \\
*\end{array}$ & $2.1 \%-4.7 \% \#$ & $2.6 \%-7.3 \%$ & $3.0 \%-7.0 \%$ & $3.0 \%-5.8 \%$ & $3.9 \%-1.1 \%$ & $\begin{array}{l}3.8 \%- \\
4.5 \%\end{array}$ \\
\hline
\end{tabular}

${ }^{*}$ The high end of the range declined from 2000 to 2002, because the utility with the highest participation rate (Moorhead Public Service) experienced an increase in its overall customer base, while the number of participants in its green pricing program remained steady. The program was fully subscribed in 2000 , and the utility has not attempted to expand it.

\#Data for April 2000 source: Bird and Brown (2005) 
Table 3.7.4: Annual Sales of Green Energy through Utility Green Pricing Programs (million kWh)

\begin{tabular}{|l|r|r|r|r|r|}
\hline & \multicolumn{1}{|c|}{$\mathbf{2 0 0 0}$} & \multicolumn{1}{c|}{$\mathbf{2 0 0 1}$} & \multicolumn{1}{c|}{$\mathbf{2 0 0 2}$} & \multicolumn{1}{c|}{$\mathbf{2 0 0 3}$} & \multicolumn{2}{c|}{$\mathbf{2 0 0 4}$} \\
\hline Residential customers & --- & 399.7 & 661.3 & 874.1 & $1,295.0$ \\
\hline Nonresidential customers & --- & 172.8 & 233.7 & 410.3 & 544.2 \\
\hline Total All customers & 453.7 & 572.5 & 895.0 & $1,284.4$ & $1,839.2$ \\
\hline$\%$ Annual Growth & & $26 \%$ & $56 \%$ & $44 \%$ & $43 \%$ \\
\hline \% Nonresidential Customers & --- & $30 \%$ & $26 \%$ & $32 \%$ & $30 \%$ \\
\hline *Sales information for customer segments not available for 2000. & & \\
\hline
\end{tabular}

Source: Bird and Brown (2005)

Table 3.7.5: Price Premiums Charged for Utility Green Pricing Products (c/kWh)

\begin{tabular}{|l|l|l|l|l|l|l|}
\hline & \multicolumn{1}{|c|}{$\mathbf{1 9 9 9}$} & \multicolumn{1}{|c|}{$\mathbf{2 0 0 0}$} & \multicolumn{1}{|c|}{$\mathbf{2 0 0 1}$} & \multicolumn{1}{|c|}{$\mathbf{2 0 0 2}$} & \multicolumn{1}{c|}{$\mathbf{2 0 0 3}$} & $\mathbf{2 0 0 4}$ \\
\hline Average & 2.15 & 3.48 & 2.93 & 2.82 & 2.62 & 2.45 \\
\hline Median & 2.00 & 2.50 & 2.50 & 2.50 & 2.00 & 2.00 \\
\hline Range & $0.4-5.0$ & $(0.5)-20.0$ & $0.9-17.6$ & $0.7-17.6$ & $0.6-17.6$ & $\begin{array}{l}0.33- \\
17.6\end{array}$ \\
\hline $\begin{array}{l}10 \text { Programs with Lowest } \\
\text { Premiums* }\end{array}$ & $0.4-2.5^{\star *}$ & $(0.5)-2.5$ & $1.0-1.5$ & $0.7-1.5$ & $0.6-1.3$ & $\begin{array}{l}0.33- \\
1.0\end{array}$ \\
\hline $\begin{array}{l}\text { Number of Programs } \\
\text { Represented }\end{array}$ & 24 & 50 & 60 & 80 & 91 & 101 \\
\hline
\end{tabular}

${ }^{*}$ Represents the 10 utility programs with the lowest price premiums for new customer-driven renewable energy. This includes only programs that have installed - or announced firm plans to install or purchase power from - new renewable energy sources. In 2001, the discrepancy between the low end of the range for all programs and the Top 10 programs was because the program with the lowest premium $(0.9 \phi / \mathrm{kWh})$ was not eligible for the Top 10, because it was either selling existing renewables or had not installed any new renewable capacity for its program.

**Data for April 2000.

Source: Bird and Brown (2005) 
Table 3.7.6: Utility Green Pricing Programs by State, October 2005

\begin{tabular}{|c|c|c|c|c|c|}
\hline State & Utility Name & $\begin{array}{l}\text { Program } \\
\text { Name }\end{array}$ & Type & $\begin{array}{l}\text { Start } \\
\text { Date }\end{array}$ & Premium \\
\hline AK & Golden Valley Electric Association & $\begin{array}{l}\text { Sustainable Natural } \\
\text { Alternative Power (SNAP) }\end{array}$ & $\begin{array}{l}\text { various local } \\
\text { projects }\end{array}$ & 2005 & Contribution \\
\hline$A L$ & Alabama Power Company & Renewable Energy Rate & $\begin{array}{l}\text { biomass co- } \\
\text { firing }\end{array}$ & 2003 & $6.0 \phi / \mathrm{kWh}$ \\
\hline$A L$ & $\begin{array}{l}\text { TVA: City of Athens Electric } \\
\text { Department, Cullman Electric Coop, } \\
\text { Cullman Power Board, Decator } \\
\text { Utilities, Florence Utilities, Hartselle } \\
\text { Utilities, Huntsville, Joe Wheeler } \\
\text { EMC, Muscle Shoals Electric Board, } \\
\text { Scottsboro Electric Power Board, } \\
\text { Sheffield Utilities, Tuscumbia Electric } \\
\text { Department }\end{array}$ & Green Power Switch & $\begin{array}{l}\text { landfill gas, } \\
\text { PV, wind }\end{array}$ & 2000 & $2.67 \phi / \mathrm{kWh}$ \\
\hline$A Z$ & Arizona Public Service & APS Solar Partners Program & central PV & 1997 & $17.6 \phi / \mathrm{kWh}$ \\
\hline$A Z$ & Salt River Project & EarthWise Energy & $\begin{array}{l}\text { central PV, } \\
\text { wind, landfill } \\
\text { gas, small } \\
\text { hydro, } \\
\text { geothermal } \\
\end{array}$ & $\begin{array}{l}1998 / \\
2001\end{array}$ & $3.0 \phi / \mathrm{kWh}$ \\
\hline$A Z$ & Tucson Electric & GreenWatts & landfill gas, PV & 2000 & $10 \phi / k W h$ \\
\hline$A Z$ & UniSource Energy Services & GreenWatts & PV & 2004 & $10 \phi / \mathrm{kWh}$ \\
\hline CA & Anaheim Public Utilities & Green Power for the Schools & PV & 2002 & Contribution \\
\hline CA & Anaheim Public Utilities & Green Power for the Grid & $\begin{array}{l}\text { wind, landfill } \\
\text { gas }\end{array}$ & 2002 & $1.5 \phi / \mathrm{kWh}$ \\
\hline $\mathrm{CA}$ & Burbank Water and Power & Clean Green Support & various & 2001 & $1.0 \phi / \mathrm{kWh}$ \\
\hline $\mathrm{CA}$ & $\begin{array}{l}\text { Los Angeles Department of Water } \\
\text { and Power }\end{array}$ & Green Power for a Green LA & $\begin{array}{l}\text { wind, landfill } \\
\text { gas }\end{array}$ & 1999 & $3.0 \phi / \mathrm{kWh}$ \\
\hline $\mathrm{CA}$ & PacifiCorp: Pacific Power & Blue Sky Block & wind & 2000 & $1.95 \phi / \mathrm{kWh}$ \\
\hline $\mathrm{CA}$ & $\begin{array}{l}\text { Palo Alto Utilities/3 Phases Energy } \\
\text { Services }\end{array}$ & Palo Alto Green & wind, PV & 2003 & $1.5 \phi / \mathrm{kWh}$ \\
\hline $\mathrm{CA}$ & Pasadena Water \& Power & Green Power & wind & 2003 & $2.5 \phi / \mathrm{kWh}$ \\
\hline CA & Roseville Electric & RE Green Energy & $\begin{array}{l}\text { geothermal, } \\
\text { PV }\end{array}$ & 2000 & $1.0 \phi / \mathrm{kWh}$ \\
\hline $\mathrm{CA}$ & Sacramento Municipal Utility District & Greenergy & $\begin{array}{l}\text { wind, landfill } \\
\text { gas, hydro, PV }\end{array}$ & 1997 & $\begin{array}{l}1.0 \phi / \mathrm{kWh} \text { or } \\
\$ 6 / \mathrm{month}\end{array}$ \\
\hline CA & $\begin{array}{l}\text { Silicon Valley Power / } 3 \text { Phases } \\
\text { Energy Services }\end{array}$ & Santa Clara Green Power & wind, PV & 2004 & $1.5 \phi / \mathrm{kWh}$ \\
\hline $\mathrm{CO}$ & Colorado Springs Utilities & Green Power & wind & 1999 & $3.0 \phi / \mathrm{kWh}$ \\
\hline $\mathrm{CO}$ & Holy Cross Energy & Wind Power Pioneers & wind & 1998 & $2.5 \phi / \mathrm{kWh}$ \\
\hline $\mathrm{CO}$ & Holy Cross Energy & $\begin{array}{l}\text { Local Renewable Energy } \\
\text { Pool }\end{array}$ & $\begin{array}{l}\text { small hydro, } \\
\text { PV }\end{array}$ & 2002 & $3.3 \phi / \mathrm{kWh}$ \\
\hline $\mathrm{CO}$ & $\begin{array}{l}\text { Platte River Power Authority: Estes } \\
\text { Park, Fort Collins Utilities, Longmont } \\
\text { Power \& Communications, Loveland } \\
\text { Water \& Light }\end{array}$ & Wind Energy Premium & wind & 1999 & $\begin{array}{l}1.0 \phi / \mathrm{kWh}- \\
2.5 \phi / \mathrm{kWh}\end{array}$ \\
\hline
\end{tabular}




\begin{tabular}{|c|c|c|c|c|c|}
\hline State & Utility Name & $\begin{array}{l}\text { Program } \\
\text { Name }\end{array}$ & Type & $\begin{array}{l}\text { Start } \\
\text { Date }\end{array}$ & Premium \\
\hline $\mathrm{CO}$ & $\begin{array}{l}\text { Tri-State Generation \& Transmission: } \\
\text { Carbon Power, Chimney Rock, } \\
\text { Gunnison County Electric, Kit Carson } \\
\text { Electric, La Plata Electric, Mountain } \\
\text { Parks Electric, Mountain View } \\
\text { Electric, New Mexico, Northwest } \\
\text { Rural, Poudre Valley Rural Electric } \\
\text { Association, Public Power District, } \\
\text { San Isabel Electric, San Luis Valley } \\
\text { Rural Electric Coop, San Miguel } \\
\text { Power, Sangre, Springer Electric, } \\
\text { United Power, White River (18 of } 44 \\
\text { coops offer program) }\end{array}$ & $\begin{array}{l}\text { Renewable Resource Power } \\
\text { Service }\end{array}$ & wind, hydro & 1998 & $2.5 \phi / \mathrm{kWh}$ \\
\hline $\mathrm{CO}$ & Xcel Energy & Renewable Energy Trust & PV & 1993 & Contribution \\
\hline $\mathrm{CO}$ & Xcel Energy & WindSource & wind & 1997 & $0.97 \phi / \mathrm{kWh}$ \\
\hline $\mathrm{CO}$ & Yampa Valley Electric Association & Wind Energy Program & wind & 1999 & $3.0 \phi / \mathrm{kWh}$ \\
\hline $\mathrm{FL}$ & City of Tallahassee/Sterling Planet & Green for You & biomass, PV & 2002 & $1.6 \phi / \mathrm{kWh}$ \\
\hline $\mathrm{FL}$ & City of Tallahassee/Sterling Planet & Green for You & PV only & 2002 & $11.6 \phi / \mathrm{kWh}$ \\
\hline $\mathrm{FL}$ & $\begin{array}{l}\text { Florida Power \& Light / Green } \\
\text { Mountain Energy }\end{array}$ & Sunshine Energy & $\begin{array}{l}\text { biomass, wind, } \\
\text { PV }\end{array}$ & 2004 & $0.975 \phi / \mathrm{kWh}$ \\
\hline $\mathrm{FL}$ & Gainesville Regional Utilities & GRUgreen Energy & $\begin{array}{l}\text { landfill gas, } \\
\text { wind, PV }\end{array}$ & 2003 & $2.0 \phi / \mathrm{kWh}$ \\
\hline $\mathrm{FL}$ & $\begin{array}{l}\text { Keys Energy Services / Sterling } \\
\text { Planet }\end{array}$ & $\begin{array}{l}\text { GO GREEN: Florida Ever } \\
\text { Green }\end{array}$ & $\begin{array}{l}\text { solar hot water, } \\
\text { PV, biomass }\end{array}$ & 2004 & $2.75 \phi / \mathrm{kWh}$ \\
\hline $\mathrm{FL}$ & $\begin{array}{l}\text { Keys Energy Services / Sterling } \\
\text { Planet }\end{array}$ & GO GREEN: USA Green & $\begin{array}{l}\text { wind, } \\
\text { biomass,PV }\end{array}$ & 2004 & $1.60 \phi / \mathrm{kWh}$ \\
\hline $\mathrm{FL}$ & Tampa Electric Company (TECO) & $\begin{array}{l}\text { Tampa Electric's Renewable } \\
\text { Energy Program }\end{array}$ & $\begin{array}{l}\mathrm{PV}, \text { landfill } \\
\text { gas, biomass } \\
\text { co-firing }\end{array}$ & 2000 & $5.0 \phi / \mathrm{kWh}$ \\
\hline $\mathrm{FL}$ & $\begin{array}{l}\text { Utilities Commission City of New } \\
\text { Smyrna Beach }\end{array}$ & Green Fund & $\begin{array}{l}\text { local PV } \\
\text { projects }\end{array}$ & 1999 & Contribution \\
\hline$\overline{G A}$ & $\begin{array}{l}\text { Georgia Electric Membership } \\
\text { Corporation (16 of } 42 \text { coops offer } \\
\text { program): Carroll EMC, Coastal } \\
\text { Electric, Cobb EMC, Coweta-Fayette } \\
\text { EMC, Flint Energies, GreyStone } \\
\text { Power, Habersham EMC, Irwin EMC, } \\
\text { Jackson EMC, Jefferson Energy, } \\
\text { Lamar EMC, Ocmulgee EMC, } \\
\text { Sawnee EMC, Snapping Shoals } \\
\text { EMC, Tri-County EMC, Walton EMC } \\
\text { of Monroe }\end{array}$ & Green Power EMC & landfill gas & 2001 & $\begin{array}{l}2.0 \phi / \mathrm{kWh}- \\
3.3 \phi / \mathrm{kWh}\end{array}$ \\
\hline$\overline{G A}$ & Georgia Power & Green Energy & landfill gas & 2005 & $5.5 \phi / \mathrm{kWh}$ \\
\hline$\overline{G A}$ & $\begin{array}{l}\text { TVA: Blue Ridge Mountain Electric } \\
\text { Membership Corporation, North } \\
\text { Georgia Electric Membership } \\
\text { Corporation }\end{array}$ & Green Power Switch & $\begin{array}{l}\text { landfill gas, } \\
\mathrm{PV}, \text { wind }\end{array}$ & 2000 & $2.67 \phi / \mathrm{kWh}$ \\
\hline $\mathrm{HI}$ & Hawaiian Electric & Sun Power for Schools & PV in schools & 1997 & Contribution \\
\hline ID & Avista Utilities & Buck-A-Block & wind & 2002 & $0.33 \phi / \mathrm{kWh}$ \\
\hline ID & Idaho Power & Green Power Program & various & 2001 & Contribution \\
\hline ID & PacifiCorp: Utah Power & Blue Sky & wind & 2003 & $1.95 \phi / \mathrm{kWh}$ \\
\hline
\end{tabular}




\begin{tabular}{|c|c|c|c|c|c|}
\hline State & Utility Name & $\begin{array}{l}\text { Program } \\
\text { Name }\end{array}$ & Type & $\begin{array}{l}\text { Start } \\
\text { Date }\end{array}$ & Premium \\
\hline ID & Vigilante Electric Cooperative & $\begin{array}{l}\text { Alternative Renewable } \\
\text { Energy Program }\end{array}$ & $\begin{array}{l}\text { wind, PV, } \\
\text { hydro }\end{array}$ & 2003 & $1.1 \phi / \mathrm{kWh}$ \\
\hline IL & $\begin{array}{l}\text { CCS/Soyland and Community } \\
\text { Energy, Inc (8 of } 11 \text { coops offer } \\
\text { program): Adams Electric Co-op, } \\
\text { Coles-Moultrie Electric, Eastern Illini } \\
\text { Electric, McDonough Power, Menard, } \\
\text { Rural Electric Convenience Co-op, } \\
\text { Shelby Electric, Spoon River Electric } \\
\text { Co-op }\end{array}$ & EcoEnergy & wind & 2005 & $3.0 \phi / \mathrm{kWh}$ \\
\hline IL & $\begin{array}{l}\text { City of Naperville / Community } \\
\text { Energy }\end{array}$ & Renewable Energy Option & $\begin{array}{l}\text { wind, small } \\
\text { hydro, PV }\end{array}$ & 2005 & $2.5 \phi / \mathrm{kWh}$ \\
\hline IL & $\begin{array}{l}\text { City of St. Charles/ComEd and } \\
\text { Community Energy }\end{array}$ & TBD & $\begin{array}{l}\text { wind, landfill } \\
\text { gas }\end{array}$ & 2003 & Contribution \\
\hline IL & $\begin{array}{l}\text { Dairyland Power Cooperative: Jo- } \\
\text { Carroll Energy/Elizabeth }\end{array}$ & $\begin{array}{l}\text { Evergreen Renewable } \\
\text { Energy Program }\end{array}$ & wind & 1997 & $1.5 \phi / \mathrm{kWh}$ \\
\hline IN & $\begin{array}{l}\text { Hoosier Energy (5 of } 17 \text { coops offer } \\
\text { program): Southeastern Indiana } \\
\text { REMC, South Central Indiana REMC, } \\
\text { Utilities District of Western Indiana } \\
\text { REMC, Decatur County REMC, } \\
\text { Daviess-Martin County REMC } \\
\end{array}$ & EnviroWatts & landfill gas & 2001 & $\begin{array}{l}2.0 \phi / \mathrm{kWh}- \\
4.0 \phi / \mathrm{kWh}\end{array}$ \\
\hline IN & Indianapolis Power \& Light & $\begin{array}{l}\text { Elect Plan Green Power } \\
\text { Program }\end{array}$ & geothermal & 1998 & $0.9 \phi / \mathrm{kWh}$ \\
\hline IN & PSI Energy/Cinergy & Green Power Rider & \begin{tabular}{|l} 
wind, PV, \\
landfill gas, \\
digester gas
\end{tabular} & 2001 & Contribution \\
\hline IN & $\begin{array}{l}\text { Wabash Valley Power Association (7 } \\
\text { of } 27 \text { coops offer program): Boone } \\
\text { REMC, Hendricks Power } \\
\text { Cooperative, Kankakee Valley } \\
\text { REMC, Miami-Cass REMC, Tipmont } \\
\text { REMC, White County REMC, } \\
\text { Northeastern REMC }\end{array}$ & EnviroWatts & landfill gas & 2000 & $\begin{array}{l}0.9 \phi / \mathrm{kWh}- \\
1.0 \phi / \mathrm{kWh}\end{array}$ \\
\hline IA & Alliant Energy & Second Nature & $\begin{array}{l}\text { landfill gas, } \\
\text { wind }\end{array}$ & 2001 & $2.0 \phi / \mathrm{kWh}$ \\
\hline IA & \begin{tabular}{|l|} 
Basin Electric Power Cooperative: \\
Lyon Rural, Harrison County, \\
Nishnabotna Valley Cooperative, \\
Northwest Rural Electric Cooperative, \\
Western lowa
\end{tabular} & Prairie Winds & wind & 2000 & $\begin{array}{l}1.0 \phi / \mathrm{kWh}- \\
2.5 \phi / \mathrm{kWh}\end{array}$ \\
\hline IA & Cedar Falls Utilities & Harvest the Wind & wind & 2000 & $2.5 \phi / \mathrm{kWh}$ \\
\hline IA & $\begin{array}{l}\text { Corn Belt Power Cooperatives (5 of } \\
11 \text { co-ops): Butler County REC, } \\
\text { Franklin REC, Grundy County REC, } \\
\text { Humboldt County REC, Sac County } \\
\text { REC }\end{array}$ & Energy Wise Renewables & wind & 2003 & $1.5 \phi / \mathrm{kWh}$ \\
\hline IA & $\begin{array}{l}\text { Dairyland Power Cooperative: } \\
\text { Allamakee-Clayton/Postville, } \\
\text { Hawkeye Tri-County/Cresco, } \\
\text { Heartland Power/Thompson \& St. } \\
\text { Ansgar }\end{array}$ & $\begin{array}{l}\text { Evergreen Renewable } \\
\text { Energy Program }\end{array}$ & wind & 1997 & $3.0 \phi / \mathrm{kWh}$ \\
\hline IA & Farmers Electric Cooperative & Green Power Project & biodiesel, winc & 2004 & Contribution \\
\hline
\end{tabular}




\begin{tabular}{|c|c|c|c|c|c|}
\hline State & Utility Name & $\begin{array}{l}\text { Program } \\
\text { Name }\end{array}$ & Type & $\begin{array}{l}\text { Start } \\
\text { Date }\end{array}$ & Premium \\
\hline IA & \begin{tabular}{|l} 
lowa Association of Municipal Utilities \\
(80 of 137 participating) Afton, \\
Algona, Alta Vista, Aplington, Auburn, \\
Bancroft, Bellevue, Bloomfield, \\
Breda, Brooklyn, Buffalo, Burt, \\
Callender, Carlisle, Cascade, \\
Coggon, Coon Rapids, Corning, \\
Corwith, Danville, Dayton, Durant, \\
Dysart, Earlville, Eldridge, Ellsworth, \\
Estherville, Fairbank, Farnhamville, \\
Fontanelle, Forest City, Gowrie, \\
Grafton, Grand Junction, Greenfield, \\
Grundy Center, Guttenberg, \\
Hopkinton, Hudson, Independence, \\
Keosauqua, La Porte City, Lake Mills, \\
Lake View, Laurens, Lenox, \\
Livermore, Maquoketa, Marathon, \\
McGregor, Milford, Montezuma, \\
Mount Pleasant, Neola, New \\
Hampton, Ogden, Orient, Osage, \\
Panora, Pella, Pocahontas, Preston, \\
Readlyn, Rockford, Sabula, Sergeant \\
Bluff, Sibley, Spencer, Stanhope, \\
State Center, Stratford, Strawberry \\
Point, Stuart, Tipton, Villisca, Vinton, \\
Webster City, West Bend, West \\
Liberty, West Point, Westfield, \\
Whittemore, Wilton, Winterset
\end{tabular} & Green City Energy & $\begin{array}{l}\text { wind, biomass, } \\
\text { PV }\end{array}$ & 2003 & $\begin{array}{l}\text { Varies by } \\
\text { utility }\end{array}$ \\
\hline IA & MidAmerican Energy & Renewable Advantage & wind & 2004 & Contribution \\
\hline IA & $\begin{array}{l}\text { Missouri River Energy Services } \\
\text { (MRES): Alton, Atlantic, Denison, } \\
\text { Fontanelle, Hartley, Hawarden, } \\
\text { Kimballton, Lake Park, Manilla, } \\
\text { Orange City, Paullina, Primghar, } \\
\text { Remsen, Rock Rapids, Sanborn, } \\
\text { Shelby, Sioux Center, Woodbine }\end{array}$ & RiverWinds & wind & 2003 & $\begin{array}{l}1.0 \phi / \mathrm{kWh}- \\
2.5 \phi / \mathrm{kWh}\end{array}$ \\
\hline IA & Muscatine Power and Water & Solar Muscatine & PV & 2004 & Contribution \\
\hline IA & Waverly Light \& Power & Green Power Choice & wind & 2003 & Contribution \\
\hline IA & Waverly Light \& Power & Iowa Energy Tags & wind & 2001 & $2.0 \phi / \mathrm{kWh}$ \\
\hline KY & \begin{tabular}{|l|} 
East Kentucky Power Cooperative: \\
Blue Grass Energy, Clark, \\
Cumberland, Fleming, Grayson, \\
Inter-county Energy, Jackson, \\
Licking, Mason, Nolin, Owen Electric, \\
Salt River, Shelby, South Kentucky \\
\end{tabular} & EnviroWatts & landfill gas & 2002 & $2.75 \phi / \mathrm{kWh}$ \\
\hline KY & $\begin{array}{l}\text { TVA: Bowling Green Municipal } \\
\text { Utilities, Franklin Electric Plant Board }\end{array}$ & Green Power Switch & $\begin{array}{l}\text { landfill gas, } \\
\mathrm{PV}, \text { wind }\end{array}$ & 2000 & $2.67 \phi / \mathrm{kWh}$ \\
\hline MA & $\begin{array}{l}\text { Concord Municipal Light Plant } \\
\text { (CMLP) }\end{array}$ & Green Power & hydro & 2004 & $3.0 \phi / \mathrm{kWh}$ \\
\hline $\mathrm{Ml}$ & Consumers Energy & Green Generation & $\begin{array}{l}\text { wind, landfill } \\
\text { gas }\end{array}$ & 2005 & $1.67 \phi / \mathrm{kWh}$ \\
\hline $\mathrm{Ml}$ & Lansing Board of Water and Light & GreenWise Electric Power & $\begin{array}{l}\text { landfill gas, } \\
\text { small hydro }\end{array}$ & 2001 & $3.0 \phi / \mathrm{kWh}$ \\
\hline $\mathrm{Ml}$ & Traverse City Light and Power & Green Rate & wind & 1996 & $1.5 \phi / \mathrm{kWh}$ \\
\hline $\mathrm{Ml}$ & Upper Peninsula Power Company & NatureWise & $\begin{array}{l}\text { wind, landfill } \\
\text { gas and animal } \\
\text { waste methane }\end{array}$ & 2004 & $4.0 \phi / \mathrm{kWh}$ \\
\hline
\end{tabular}




\begin{tabular}{|c|c|c|c|c|c|}
\hline State & Utility Name & $\begin{array}{l}\text { Program } \\
\text { Name }\end{array}$ & Type & $\begin{array}{l}\text { Start } \\
\text { Date }\end{array}$ & Premium \\
\hline $\mathrm{Ml}$ & We Energies & Energy for Tomorrow & $\begin{array}{l}\text { wind, landfill } \\
\text { gas, hydro }\end{array}$ & 2000 & $2.0 \phi / \mathrm{kWh}$ \\
\hline MN & Alliant Energy & Second Nature & $\begin{array}{l}\text { landfill gas, } \\
\text { wind }\end{array}$ & 2002 & $2.0 \phi / \mathrm{kWh}$ \\
\hline MN & $\begin{array}{l}\text { Basin Electric Power Cooperative: } \\
\text { Minnesota Valley Electric Coop, } \\
\text { Sioux Valley Southwestern }\end{array}$ & Prairie Winds & wind & 2002 & $\begin{array}{l}1.0 \phi / \mathrm{kWh}- \\
2.5 \phi / \mathrm{kWh}\end{array}$ \\
\hline MN & $\begin{array}{l}\text { Central Minnesota Municipal Power } \\
\text { Agency }\end{array}$ & Green Energy Program & $\begin{array}{l}\text { wind, landfill } \\
\text { gas }\end{array}$ & $n / a$ & $\begin{array}{l}1.5 \phi / \mathrm{kWh}- \\
2.5 \phi / \mathrm{kWh}\end{array}$ \\
\hline MN & $\begin{array}{l}\text { Dairyland Power Cooperative: } \\
\text { Freeborn-Mower Cooperative / Albert } \\
\text { Lea, People's / Rochester, Tri-County } \\
\text { / Rushford }\end{array}$ & $\begin{array}{l}\text { Evergreen Renewable } \\
\text { Energy Program }\end{array}$ & wind & 1997 & $1.5 \phi / \mathrm{kWh}$ \\
\hline MN & \begin{tabular}{|l|} 
Great River Energy (all 28 coops \\
offer program): Agralite, Arrowhead, \\
BENCO Electric, Brown County Rural \\
Electric, Connexus Energy, Co-op \\
Light \& Power, Crow Wing Power, \\
Dakota Electric Association, East \\
Central Electric Association, \\
Federated Rural Electric, Goodhue \\
County, Itasca Mantrap Cooperative, \\
Kandiyohi Power Cooperative, Lake \\
Country Power, Lake Region Electric \\
Cooperative, McLeod Cooperative \\
Power, Meeker Cooperative Light \& \\
Power, Mille Lacs Electric \\
Cooperative, Minnesota Valley, \\
Nobles Cooperative Electric, North \\
Itasca, Redwood Electric \\
Cooperative, Runestone Electric, \\
South Central Electric Association, \\
Stearns Electric, Steele-Waseca, \\
Todd-Wadena, Wright-Hennepin \\
Electric
\end{tabular} & $\begin{array}{l}\text { Wellspring Renewable Wind } \\
\text { Energy Program }\end{array}$ & wind & 1998 & $\begin{array}{l}1.45 \phi / \mathrm{kWh}- \\
2.0 \phi / \mathrm{kWh}\end{array}$ \\
\hline MN & Minnesota Power & WindSense & wind & 2002 & $2.5 \phi / \mathrm{kWh}$ \\
\hline MN & \begin{tabular}{|l|} 
Minnkota Power Cooperative: \\
Beltrami, Clearwater Polk, North Star, \\
PKM, Red Lake, Red River, Roseau, \\
Wild Rice, Thief River Falls \\
\end{tabular} & Infinity Wind Energy & wind & 1999 & $1.5 \phi / \mathrm{kWh}$ \\
\hline MN & $\begin{array}{l}\text { Missouri River Energy Services (39 } \\
\text { of } 55 \text { munis offer program): Adrian, } \\
\text { Alexandria, Barnesville, Benson, } \\
\text { Breckenridge, Detroit Lakes, Elbow } \\
\text { Lake, Henning, Jackson, Lakefield, } \\
\text { Lake Park, Luverne, Madison, } \\
\text { Moorhead, Ortonville, St. James, } \\
\text { Sauk Centre, Staples, Wadena, } \\
\text { Westbrook, Worthington }\end{array}$ & RiverWinds & wind & 2002 & $\begin{array}{l}1.0 \phi / \mathrm{kWh}- \\
2.5 \phi / \mathrm{kWh}\end{array}$ \\
\hline MN & Moorhead Public Service & Capture the Wind & wind & 1998 & $1.5 \phi / \mathrm{kWh}$ \\
\hline MN & Otter Tail Power Company & TailWinds & wind & 2002 & $2.6 \phi / \mathrm{kWh}$ \\
\hline
\end{tabular}




\begin{tabular}{|c|c|c|c|c|c|}
\hline State & Utility Name & $\begin{array}{l}\text { Program } \\
\text { Name }\end{array}$ & Type & $\begin{array}{l}\text { Start } \\
\text { Date }\end{array}$ & Premium \\
\hline $\mathrm{MN}$ & $\begin{array}{l}\text { Southern Minnesota Municipal Power } \\
\text { Agency (all } 18 \text { offer program): } \\
\text { Fairmont Public Utilities, Wells Public } \\
\text { Utilities, Austin Utilities, Preston } \\
\text { Public Utilities, Spring Valley Utilities, } \\
\text { Blooming Prairie Public Utilities, } \\
\text { Rochester Public Utilities, Owatonna } \\
\text { Public Utilities, Waseca Utilities, St. } \\
\text { Peter Municipal Utilities, Lake City } \\
\text { Utilities, New Prague Utilities } \\
\text { Commission, Redwood Falls Public } \\
\text { Utilities, Litchield Public Utilities, } \\
\text { Princeton Public Utilities, North } \\
\text { Branch Water and Light, Mora } \\
\text { Municipal Utilities, Grand Marais } \\
\text { Public Utilities }\end{array}$ & SMMPA Wind Power & wind & 2000 & $1.0 \phi / \mathrm{kWh}$ \\
\hline MN & Xcel Energy & WindSource & wind & 2003 & $2.0 \phi / \mathrm{kWh}$ \\
\hline MS & $\begin{array}{l}\text { TVA: City of Oxford, North East } \\
\text { Mississippi Electric Power } \\
\text { Asssociation, Starkville Electric } \\
\text { System }\end{array}$ & Green Power Switch & $\begin{array}{l}\text { landfill gas, } \\
\text { PV, wind }\end{array}$ & 2000 & $2.67 \phi / \mathrm{kWh}$ \\
\hline MO & Boone Electric Cooperative & Renewable Choice & wind & 2003 & $2.0 \phi / \mathrm{kWh}$ \\
\hline MO & City Utilities of Springfield & WindCurrent & wind & 2000 & $5.0 \phi / \mathrm{kWh}$ \\
\hline MT & $\begin{array}{l}\text { Basin Electric Power Cooperative: } \\
\text { Lower Yellowstone }\end{array}$ & Prairie Winds & wind & 2000 & $\begin{array}{l}1.0 \phi / \mathrm{kWh}- \\
2.5 \phi / \mathrm{kWh}\end{array}$ \\
\hline MT & Northwestern Energy & E+ Green & wind, PV & 2003 & $2.0 \phi / \mathrm{kWh}$ \\
\hline MT & Park Electric Cooperative & Green Power Program & wind, hydro & 2002 & $1.2 \phi / \mathrm{kWh}$ \\
\hline MT & $\begin{array}{l}\text { Southern Montana Electric } \\
\text { Generation and Transmission } \\
\text { Cooperative (5 co-ops): Fergus } \\
\text { Electric, Yellowstone Valley, Bear } \\
\text { Tooth Electric, Mid Yellowstone, and } \\
\text { Tongue River }\end{array}$ & $\begin{array}{l}\text { Environmentally Preferred } \\
\text { Power }\end{array}$ & wind, hydro & 2002 & $1.05 \phi / \mathrm{kWh}$ \\
\hline MT & Vigilante Electric Cooperative & $\begin{array}{l}\text { Alternative Renewable } \\
\text { Energy Program }\end{array}$ & $\begin{array}{l}\text { wind, hydro, } \\
\text { PV }\end{array}$ & 2003 & $1.1 \phi / \mathrm{kWh}$ \\
\hline $\mathrm{NE}$ & Lincoln Electric System & $\begin{array}{l}\text { LES Renewable Energy } \\
\text { Program }\end{array}$ & wind & 1998 & $4.3 \phi / \mathrm{kWh}$ \\
\hline NE & Omaha Public Power District & Green Power Program & $\begin{array}{l}\text { landfill gas, } \\
\text { wind }\end{array}$ & 2002 & $3.0 \phi / \mathrm{kWh}$ \\
\hline $\mathrm{NE}$ & $\begin{array}{l}\text { Tri-State: Chimney Rock Public } \\
\text { Power District, Northwest Rural } \\
\text { Public Power District }\end{array}$ & $\begin{array}{l}\text { Renewable Resource Power } \\
\text { Service }\end{array}$ & $\begin{array}{l}\text { wind, landfill } \\
\text { gas }\end{array}$ & 2001 & $2.5 \phi / \mathrm{kWh}$ \\
\hline NM & EI Paso Electric & Renewable Energy Tariff & wind & 2003 & $3.19 \phi / \mathrm{kWh}$ \\
\hline NM & $\begin{array}{l}\text { Los Alamos Department of Public } \\
\text { Utilities }\end{array}$ & Green Power & wind & 2005 & $1.8 \phi / \mathrm{kWh}$ \\
\hline NM & Public Service of New Mexico & PNM Sky Blue & wind & 2003 & $1.8 \phi / \mathrm{kWh}$ \\
\hline NM & $\begin{array}{l}\text { Tri-State: Kit Carson Electric } \\
\text { Cooperative }\end{array}$ & $\begin{array}{l}\text { Renewable Resource Power } \\
\text { Service }\end{array}$ & $\begin{array}{l}\text { wind, landfill } \\
\text { gas }\end{array}$ & 2001 & $2.5 \phi / \mathrm{kWh}$ \\
\hline NM & Xcel Energy & WindSource & wind & 1999 & $3.0 \phi / \mathrm{kWh}$ \\
\hline $\mathrm{NC}$ & Dominion North Carolina Power & NC GreenPower & $\begin{array}{l}\text { biomass, wind, } \\
\text { solar }\end{array}$ & 2003 & $4.0 \phi / \mathrm{kWh}$ \\
\hline $\mathrm{NC}$ & Duke Power & NC GreenPower & $\begin{array}{l}\text { biomass, wind, } \\
\text { solar }\end{array}$ & 2003 & $4.0 \phi / \mathrm{kWh}$ \\
\hline
\end{tabular}




\begin{tabular}{|c|c|c|c|c|c|}
\hline State & Utility Name & $\begin{array}{c}\text { Program } \\
\text { Name }\end{array}$ & Type & $\begin{array}{l}\text { Start } \\
\text { Date }\end{array}$ & Premium \\
\hline NC & $\begin{array}{l}\text { ElectriCities: City of High Point, City } \\
\text { of Laurinburg, City of Newton, City of } \\
\text { Shelby, City of Statesville, town of } \\
\text { Apex, Town of Granite Falls }\end{array}$ & NC GreenPower & $\begin{array}{l}\text { biomass, wind, } \\
\text { solar }\end{array}$ & 2003 & $4.0 \phi / \mathrm{kWh}$ \\
\hline NC & $\begin{array}{l}\text { NC Electric Cooperatives (15 of } 27 \\
\text { cooperatives offer the program): } \\
\text { Albemarle EMC, Blue Ridge Electric } \\
\text { Membership Corp., Brunswick } \\
\text { Electric Membership Corp., Carteret } \\
\text { Craven Electric Coop., Edgecombe- } \\
\text { Martin County Electric Membership } \\
\text { Corp., EnergyUnited, Four County } \\
\text { Electric Membership Corp., Haywood } \\
\text { Electric Membership Corp., Jones- } \\
\text { Onslow Electric Membership Corp., } \\
\text { Pee Dee Electric Membership Corp., } \\
\text { Piedmont Electric Membership Corp., } \\
\text { Randolph Electric Membership Corp., } \\
\text { Roanoke Electric Membership Corp., } \\
\text { Tri-County Electric Membership } \\
\text { Corp., Wake Electric Membership } \\
\text { Corp. }\end{array}$ & NC GreenPower & $\begin{array}{l}\text { biomass, wind, } \\
\text { PV }\end{array}$ & 2003 & $4.0 \phi / \mathrm{kWh}$ \\
\hline $\mathrm{NC}$ & Progress Energy / CP\&L & NC GreenPower & $\begin{array}{l}\text { biomass, wind, } \\
\text { solar }\end{array}$ & 2003 & $4.0 \phi / \mathrm{kWh}$ \\
\hline $\mathrm{NC}$ & TVA: Mountain Electric Cooperative & Green Power Switch & $\begin{array}{l}\text { landfill gas, } \\
\text { PV, wind }\end{array}$ & 2000 & $2.67 \phi / \mathrm{kWh}$ \\
\hline ND & $\begin{array}{l}\text { Basin Electric Power Cooperative (49 } \\
\text { coops offer program in } 5 \text { states): } \\
\text { Oliver Mercer Electric Coop, Mor- } \\
\text { gran-sou Electric Coop, KEM Electric } \\
\text { Coop, North Central Electric Coop, } \\
\text { Verendrye, Capital , Northern Plains, } \\
\text { Dakota Valley, Burke Divide, Montrail } \\
\text { Williams, McKenzie Electric Coop, } \\
\text { West Plains, Slope Electric Coop }\end{array}$ & PrairieWinds & wind & 2000 & $\begin{array}{l}1.0 \phi / \mathrm{kWh}- \\
2.5 \phi / \mathrm{kWh}\end{array}$ \\
\hline ND & $\begin{array}{l}\text { Minnkota Power Cooperative: Cass } \\
\text { County Electric, Cavalier Rural } \\
\text { Electric, Nodak Electric, Northern } \\
\text { Municipal Power Agency (12 } \\
\text { municipals) }\end{array}$ & Infinity Wind Energy & wind & 1999 & $1.5 \phi / \mathrm{kWh}$ \\
\hline ND & $\begin{array}{l}\text { Missouri River Energy Services: City } \\
\text { of Lakota }\end{array}$ & RiverWinds & wind & 2002 & $\begin{array}{l}1.0 \phi / \mathrm{kWh}- \\
2.5 \phi / \mathrm{kWh}\end{array}$ \\
\hline $\mathrm{OH}$ & $\begin{array}{l}\text { American Municipal Power-Ohio / } \\
\text { Green Mountain Energy: City of } \\
\text { Bowling Green, Cuyahoga Falls, } \\
\text { Wyandotte }\end{array}$ & Nature's Energy & $\begin{array}{l}\text { small hydro, } \\
\text { landfill gas, } \\
\text { wind }\end{array}$ & 2003 & $\begin{array}{l}1.3 \phi / \mathrm{kWh}- \\
1.5 \phi / \mathrm{kWh}\end{array}$ \\
\hline OK & OG\&E Electric Services & OG\&E Wind Power & wind & 2003 & $2.0 \phi / \mathrm{kWh}$ \\
\hline $\mathrm{OK}$ & $\begin{array}{l}\text { Oklahoma Municipal Power Authority: } \\
\text { Tonkawa, Altus, Frederick, Okeene, } \\
\text { Prague Municipal Utilities and } \\
\text { Edmond Electric }\end{array}$ & Pure \& Simple & wind & 2004 & $1.8 \phi / \mathrm{kWh}$ \\
\hline
\end{tabular}




\begin{tabular}{|c|c|c|c|c|c|}
\hline State & Utility Name & $\begin{array}{l}\text { Program } \\
\text { Name }\end{array}$ & Type & $\begin{array}{l}\text { Start } \\
\text { Date }\end{array}$ & Premium \\
\hline$\overline{\mathrm{OK}}$ & $\begin{array}{l}\text { Western Farmers Electric } \\
\text { Cooperative (19 of 19): Alfalfa } \\
\text { Electric Cooperative, Caddo Electric } \\
\text { Cooperative, Canadian Valley } \\
\text { Electric Cooperative, Choctaw Electri } \\
\text { Cooperative, Cimmaron Electric } \\
\text { Cooperative, Cotton Electric } \\
\text { Cooperative, East Central Oklahoma } \\
\text { Electric Cooperative, Harmon Electric } \\
\text { Cooperative, Kay Electric } \\
\text { Cooperative, Kiamichi Electric } \\
\text { Cooperative, Kiwash Electric } \\
\text { Cooperative, Northfork Electric } \\
\text { Cooperative, Northwestern Electric } \\
\text { Cooperative, Oklahoma Electric } \\
\text { Cooperative, People's Electric } \\
\text { Cooperative, Red River Valley Rural } \\
\text { Electric Cooperative, Rural Electric } \\
\text { Cooperative, Southeastern Electric } \\
\text { Cooperative, Southwest Rural } \\
\text { Electric Cooperative }\end{array}$ & WindWorks & wind & 2004 & $0.5 \phi / \mathrm{kWh}$ \\
\hline OR & $\begin{array}{l}\text { City of Ashland/Bonneville } \\
\text { Environmental Foundation }\end{array}$ & Renewable Pioneers & $P V$, wind & 2003 & $2.0 \phi / \mathrm{kWh}$ \\
\hline OR & Columbia River PUD & Choice Energy & wind & 2005 & $2.0 \phi / \mathrm{kWh}$ \\
\hline OR & \begin{tabular}{|l} 
Emerald People's Utility \\
District/Green Mountain Energy
\end{tabular} & $\begin{array}{l}\text { Choose Renewable } \\
\text { Electricity }\end{array}$ & $\begin{array}{l}\text { wind, } \\
\text { geothermal }\end{array}$ & 2003 & $1.2 \phi / \mathrm{kWh}$ \\
\hline$\overline{\mathrm{OR}}$ & Eugene Water \& Electric Board & EWEB Wind Power & wind & 1999 & $0.71 \phi / \mathrm{kWh}$ \\
\hline OR & Midstate Electric Cooperative & $\begin{array}{l}\text { Environmentally-Preferred } \\
\text { Power }\end{array}$ & $\begin{array}{l}\text { wind, small } \\
\text { hydro }\end{array}$ & 1999 & $2.5 \phi / \mathrm{kWh}$ \\
\hline OR & Oregon Trail Electric Cooperative & Green Power & wind & 2002 & $1.5 \phi / \mathrm{kWh}$ \\
\hline OR & PacifiCorp: Pacific Power & $\begin{array}{l}\text { Blue Sky QS (Commercial } \\
\text { Only) }\end{array}$ & wind & 2004 & \begin{tabular}{|l|} 
Sliding scale \\
depending \\
on size
\end{tabular} \\
\hline OR & PacifiCorp: Pacific Power & Blue Sky Block & wind & 2000 & $1.95 \phi / \mathrm{kWh}$ \\
\hline OR & $\begin{array}{l}\text { PacifiCorp: Pacific Power / } 3 \text { Phases } \\
\text { Energy Services }\end{array}$ & Blue Sky Usage & $\begin{array}{l}\text { wind, biomass, } \\
\text { PV }\end{array}$ & 2002 & $0.78 \phi / \mathrm{kWh}$ \\
\hline OR & $\begin{array}{l}\text { PacifiCorp: Pacific Power / } 3 \text { Phases } \\
\text { Energy Services }\end{array}$ & Blue Sky Habitat & $\begin{array}{l}\text { wind, biomass, } \\
\text { PV }\end{array}$ & 2002 & $\begin{array}{l}0.78 \phi / \mathrm{kWh}+ \\
\$ 2.50 / \mathrm{mo} . \\
\text { donation }\end{array}$ \\
\hline OR & $\begin{array}{l}\text { Pacific Northwest Generating } \\
\text { Cooperative: Central Electric } \\
\text { Cooperative, Clearwater Power, } \\
\text { Consumers Power, Douglas Electric } \\
\text { Cooperative, Umatilla Electric } \\
\text { Cooperative (5 of } 16 \text { coops offer } \\
\text { program) }\end{array}$ & Green Power & landfill gas & 1998 & $\begin{array}{l}1.8 \phi / \mathrm{kWh}- \\
4.0 \phi / \mathrm{kWh}\end{array}$ \\
\hline OR & $\begin{array}{l}\text { Portland General Electric / Green } \\
\text { Mountain Energy }\end{array}$ & Green Source & $\begin{array}{l}\text { existing } \\
\text { geothermal, } \\
\text { wind }\end{array}$ & 2002 & $0.8 \phi / \mathrm{kWh}$ \\
\hline $\mathrm{OR}$ & $\begin{array}{l}\text { Portland General Electric / Green } \\
\text { Mountain Energy }\end{array}$ & Healthy Habitat & $\begin{array}{l}\text { existing } \\
\text { geothermal, } \\
\text { wind }\end{array}$ & 2002 & $\begin{array}{l}0.8 \phi / \mathrm{kWh}+ \\
\$ 2.50 / \mathrm{mo} . \\
\text { donation }\end{array}$ \\
\hline OR & Portland General Electric Company & $\begin{array}{l}\text { Clean Wind for Medium to } \\
\text { Large Commercial \& } \\
\text { Industrial Accounts }\end{array}$ & wind & 2003 & $\begin{array}{l}1.35 \phi / \mathrm{kWh}- \\
1.7 \phi / \mathrm{kWh}\end{array}$ \\
\hline
\end{tabular}




\begin{tabular}{|c|c|c|c|c|c|}
\hline State & Utility Name & $\begin{array}{l}\text { Program } \\
\text { Name }\end{array}$ & Type & $\begin{array}{l}\text { Start } \\
\text { Date }\end{array}$ & Premium \\
\hline OR & Portland General Electric Company & Clean Wind Power & wind & 2002 & $1.75 \phi / \mathrm{kWh}$ \\
\hline SC & $\begin{array}{l}\text { Santee Cooper, Aiken Electric } \\
\text { Cooperative, Berkeley Electric } \\
\text { Cooperative, Edisto Electric } \\
\text { Cooperative, Fairfield Electric } \\
\text { Cooperative, Horry Electric } \\
\text { Cooperative, Laurens Electric } \\
\text { Cooperative, Lynches River Electric } \\
\text { Cooperative, Marlboro Electric } \\
\text { Cooperative, Mid-Carolina Electric } \\
\text { Cooperative, Palmetto Electric } \\
\text { Cooperative, Pee Dee Electric } \\
\text { Cooperative, Santee Electric } \\
\text { Cooperative, Tri-County Electric } \\
\text { Cooperative, York Electric } \\
\text { Cooperative }\end{array}$ & Green Power Program & landfill gas & 2001 & $3.0 \phi / \mathrm{kWh}$ \\
\hline SD & $\begin{array}{l}\text { Basin Electric Power Cooperative: } \\
\text { Bon Homme-Yankton Electric Assn., } \\
\text { Central Electric Cooperative } \\
\text { Association, Charles Mix Electric } \\
\text { Association, City of Elk Point, Clay- } \\
\text { Union Electric Corporation, } \\
\text { Codington-Clark Electric } \\
\text { Cooperative, Dakota Energy } \\
\text { Cooperative, Douglas Electric } \\
\text { Cooperative, FEM Electric } \\
\text { Association, H-D Electric } \\
\text { Cooperative, Kingsbury Electric } \\
\text { Cooperative, Lyon-Lincoln Electric } \\
\text { Cooperative, McCook Electric } \\
\text { Cooperative, Northern Electric } \\
\text { Cooperative, Oahe Electric } \\
\text { Cooperative, Renville-Sibley Coop. } \\
\text { Power Assn., Sioux Valley } \\
\text { Southwestern Electric Coop, } \\
\text { Southeastern Electric Coop, Union } \\
\text { County Electric Cooperative, } \\
\text { Whetstone Valley Electric } \\
\text { Cooperative, Black Hills Electric } \\
\text { Coop, LaCreek Electric Coop, West } \\
\text { River Power Association, Butte } \\
\text { Electric Coop, Cherry Todd Electric } \\
\text { Coop, Moreau Grand, Grand Electric } \\
\text { Cooperative, Rosebud } \\
\end{array}$ & Prairie Winds & wind & 2000 & $\begin{array}{l}1.0 \phi / \mathrm{kWh}- \\
2.5 \phi / \mathrm{kWh}\end{array}$ \\
\hline SD & $\begin{array}{l}\text { Missouri River Energy Services: City } \\
\text { of Vermillion }\end{array}$ & RiverWinds & wind & 2002 & $\begin{array}{l}1.0 \phi / \mathrm{kWh}- \\
2.5 \phi / \mathrm{kWh}\end{array}$ \\
\hline TN & $\begin{array}{l}\text { TVA: Alcoa Electric Department, } \\
\text { Appalachian Electric Cooperative, } \\
\text { Athens Utility Board, Bristol } \\
\text { Tennessee Electric System, Caney } \\
\text { Fork Electric Cooperative, City of } \\
\text { Maryville Electric Department, } \\
\text { Clarksville Department of Electricity, } \\
\text { Cleveland Utilities, Clinton Utilities } \\
\text { Board, Cookeville Electric } \\
\text { Department, Cumberland Electric } \\
\text { Membership Corporation, Dickson } \\
\text { Electric Department, Duck River } \\
\text { Electric Membership Corporation, }\end{array}$ & Green Power Switch & $\begin{array}{l}\text { landfill gas, } \\
\text { PV, wind }\end{array}$ & 2000 & $2.67 \phi / \mathrm{kWh}$ \\
\hline
\end{tabular}




\begin{tabular}{|c|c|c|c|c|c|}
\hline State & Utility Name & $\begin{array}{l}\text { Program } \\
\text { Name }\end{array}$ & Type & $\begin{array}{l}\text { Start } \\
\text { Date }\end{array}$ & Premium \\
\hline & \begin{tabular}{|l|} 
Elizabethton Electric System, EPB \\
(Chattanooga), Erwin Utilities, \\
Fayetteville Public Utilities, Gibson \\
Electric Membership Corporation, \\
Greeneville Light and Power System, \\
Harriman Utility Board, Johnson City \\
Power Board, Jackson Energy \\
Authority, Knoxville Utilities Board, \\
Lafollette Utilities Board, \\
Lawrenceburg Power System, Lenoir \\
City Utilities Board, Loudon Utilities, \\
McMinnville Electric System, \\
Memphis Light, Gas \& Water, \\
Meriwhether Lewis Electric \\
Cooperative, Middle Tennessee \\
Electric Membership Corporation, \\
Morristown Power System, Mountain \\
Electric Cooperative, Murfreesboro \\
Electric Department, Nashville \\
Electric Service, Newport Utilities, \\
Oak Ridge Electric Department, Paris \\
Board of Public Utilities, Plateau \\
Electric Cooperative, Powell Valley \\
Electric Cooperative, Pulaski Electric \\
System, Sequachee Valley Electric \\
Cooperative, Sevier County Electric \\
System, Springfield Department of \\
Electricity, Sweetwater Utilities \\
Board, Tullahoma Utilities Board, \\
Upper Cumberland Electric \\
Membership Corporation, Volunteer \\
Energy
\end{tabular} & & & & \\
\hline TX & Austin Energy (City of Austin) & GreenChoice & $\begin{array}{l}\text { wind, landfill } \\
\text { gas, hydro }\end{array}$ & $\begin{array}{l}2000 / 19 \\
97\end{array}$ & $0.5 \phi / \mathrm{kWh}$ \\
\hline $\mathrm{TX}$ & City Public Service of San Antonio & Windtricity & wind & 2000 & $3.0 \phi / \mathrm{kWh}$ \\
\hline $\mathrm{TX}$ & El Paso Electric Company & Renewable Energy Tariff & wind & 2001 & $1.92 \phi / \mathrm{kWh}$ \\
\hline UT & City of St. George & Clean Green Power & $\begin{array}{l}\text { wind, small } \\
\text { hydro }\end{array}$ & 2005 & $2.95 \phi / \mathrm{kWh}$ \\
\hline UT & Deseret Power & GreenWay & various & 2004 & $1.95 \phi / \mathrm{kWh}$ \\
\hline UT & Pacificorp: Utah Power & Blue Sky & wind & 2000 & $1.95 \phi / \mathrm{kWh}$ \\
\hline VT & Central Vermont Public Service & CVPS Cow Power & biogas & 2004 & $4.0 \phi / \mathrm{kWh}$ \\
\hline VT & Green Mountain Power & CoolHome / CoolBusiness & wind, biomass & 2002 & Contribution \\
\hline WA & Avista Utilities & Buck-A-Block & wind & 2002 & $0.33 \phi / \mathrm{kWh}$ \\
\hline WA & Benton County Public Utility District & Green Power Program & $\begin{array}{l}\text { landfill gas, } \\
\text { wind }\end{array}$ & 1999 & Contribution \\
\hline WA & Chelan County PUD & $\begin{array}{l}\text { Sustainable Natural } \\
\text { Alternative Power (SNAP) }\end{array}$ & $\begin{array}{l}\text { PV, wind, } \\
\text { micro hydro }\end{array}$ & 2001 & Contribution \\
\hline WA & Clallam County PUD & $\begin{array}{l}\text { Clallam County PUD Green } \\
\text { Power Program }\end{array}$ & landfill gas & 2001 & $0.7 \phi / \mathrm{kWh}$ \\
\hline WA & Clark Public Utilities & Green Lights & PV, wind & 2002 & $1.5 \phi / \mathrm{kWh}$ \\
\hline WA & Cowlitz PUD & $\begin{array}{l}\text { Renewable Resource } \\
\text { Energy }\end{array}$ & wind, PV & 2002 & $2.0 \phi / \mathrm{kWh}$ \\
\hline
\end{tabular}




\begin{tabular}{|c|c|c|c|c|c|}
\hline State & Utility Name & $\begin{array}{l}\text { Program } \\
\text { Name }\end{array}$ & Type & $\begin{array}{l}\text { Start } \\
\text { Date }\end{array}$ & Premium \\
\hline WA & Grant County PUD & \begin{tabular}{|l|} 
Alternative Energy \\
Resources Program
\end{tabular} & wind & 2002 & $2.0 \phi / \mathrm{kWh}$ \\
\hline WA & Grays Harbor PUD & Green Power & wind & 2002 & $3.0 \phi / \mathrm{kWh}$ \\
\hline WA & Lewis County PUD & Green Power Energy Rate & wind & 2003 & $2.0 \phi / \mathrm{kWh}$ \\
\hline WA & Mason County PUD No. 3 & Mason Evergreen Power & wind & 2003 & $2.0 \phi / \mathrm{kWh}$ \\
\hline WA & Orcas Power \& Light & Go Green & wind, hydro & 1999 & $3.5 \phi / \mathrm{kWh}$ \\
\hline WA & Pacific County PUD & Green Power & landfill gas & 2002 & $1.05 \phi / \mathrm{kWh}$ \\
\hline WA & Pacificorp: Pacific Power & Blue Sky & wind & 2000 & $1.95 \phi / \mathrm{kWh}$ \\
\hline WA & Peninsula Light & Green by Choice & wind, hydro & 2002 & $2.8 \phi / \mathrm{kWh}$ \\
\hline WA & Puget Sound Energy & Green Power Plan & $\begin{array}{l}\text { wind, PV, } \\
\text { biogas }\end{array}$ & 2002 & $2.0 \phi / \mathrm{kWh}$ \\
\hline WA & Seattle City Light & Green UP (C\&I only) & wind & 2005 & $1.5 \phi / \mathrm{kWh}$ \\
\hline WA & Seattle City Light & Seattle Green Power & PV, biogas & 2002 & Contribution \\
\hline WA & $\begin{array}{l}\text { Snohomish County Public Utility } \\
\text { District }\end{array}$ & Planet Power & wind & 2002 & $2.0 \phi / \mathrm{kWh}$ \\
\hline WA & Tacoma Power & EverGreen Options & $\begin{array}{l}\text { small hydro, } \\
\text { wind }\end{array}$ & 2000 & $1.5 \phi / \mathrm{kWh}$ \\
\hline WI & Alliant Energy & Second Nature & $\begin{array}{l}\text { wind, landfill } \\
\text { gas }\end{array}$ & 2000 & $2.0 \phi / \mathrm{kWh}$ \\
\hline WI & $\begin{array}{l}\text { Dairyland Power Cooperative: Barron } \\
\text { Electric, Bayfield/ Iron River, } \\
\text { Chippewa / Cornell Valley, Clark / } \\
\text { Greenwood, Dunn / Menomonie, Eau } \\
\text { Claire / Fall Creek, Jackson / Black } \\
\text { River Falls, Jump River / Ladysmith, } \\
\text { Oakdale, Pierce-Pepin / Ellsworth, } \\
\text { Polk-Burnett / Centuria, Price / } \\
\text { Phillips, Richland, Riverland / } \\
\text { Arcadia, St. Croix / Baldwin, Scenic } \\
\text { Rivers / Lancaster, Taylor / Medford, } \\
\text { Vernon / Westby }\end{array}$ & $\begin{array}{l}\text { Evergreen Renewable } \\
\text { Energy Program }\end{array}$ & wind & 1998 & $1.5 \phi / \mathrm{kWh}$ \\
\hline WI & $\begin{array}{l}\text { Great River Energy: Head of the } \\
\text { Lakes }\end{array}$ & $\begin{array}{l}\text { Wellspring Renewable Wind } \\
\text { Energy Program }\end{array}$ & wind & 1997 & $\begin{array}{l}1.45 \phi / \mathrm{kWh}- \\
2.0 \phi / \mathrm{kWh}\end{array}$ \\
\hline WI & Madison Gas \& Electric & Wind Power Program & wind & 1999 & $3.3 \phi / \mathrm{kWh}$ \\
\hline WI & We Energies & Energy for Tomorrow & $\begin{array}{l}\text { landfill gas, } \\
\text { hydro, wind }\end{array}$ & 1996 & $2.04 \phi / \mathrm{kWh}$ \\
\hline WI & $\begin{array}{l}\text { Wisconsin Public Power Inc. (34 of } \\
37 \text { munis offer program): Algoma, } \\
\text { Cedarburg, Florence, Kaukauna, } \\
\text { Muscoda, Stoughton, Reedsburg, } \\
\text { Oconomowoc, Waterloo, Whitehall, } \\
\text { Columbus, Hartford, Lake Mills, New } \\
\text { Holstein, Richland Center, Boscobel, } \\
\text { Cuba City, Hustisford, Sturgeon Bay, } \\
\text { Waunake, Lodi, New London, } \\
\text { Plymouth, River Falls, Sun Prairie, } \\
\text { Waupun, Eagle River, Jefferson, } \\
\text { Menasha, New Richmond, Prairie du } \\
\text { Sac, Slinger, Two Rivers, Westby }\end{array}$ & Renewable Energy Program & $\begin{array}{l}\text { small hydro, } \\
\text { wind, biogas }\end{array}$ & 2001 & $2.0 \phi / \mathrm{kWh}$ \\
\hline WI & Wisconsin Public Service & NatureWise & $\begin{array}{l}\text { wind, landfill } \\
\text { gas, biogas }\end{array}$ & 2002 & $1.86 \phi / \mathrm{kWh}$ \\
\hline $\mathrm{WI}$ & Wisconsin Public Service & Solar Wise for Schools & PV in schools & 1996 & Contribution \\
\hline
\end{tabular}




\begin{tabular}{|l|l|l|l|l|l|}
\hline State & \multicolumn{1}{|c|}{ Utility Name } & \multicolumn{1}{|c|}{$\begin{array}{c}\text { Program } \\
\text { Name }\end{array}$} & \multicolumn{1}{|c|}{ Type } & $\begin{array}{l}\text { Start } \\
\text { Date }\end{array}$ & \multicolumn{1}{c|}{ Premium } \\
\hline WY & Lower Valley Energy & Green Power & wind & 2003 & $1.17 \phi / \mathrm{kWh}$ \\
\hline WY & Pacificorp: Pacific Power & Blue Sky & wind & 2000 & $1.95 \phi / \mathrm{kWh}$ \\
\hline WY & Tri-State: Carbon Power \& Light & $\begin{array}{l}\text { Renewable Resource Power } \\
\text { Service }\end{array}$ & $\begin{array}{l}\text { wind, landfill } \\
\text { gas }\end{array}$ & 2001 & $2.5 \phi / \mathrm{kWh}$ \\
\hline WY & Yampa Valley Electric Association & Wind Energy Program & wind & 1999 & $3.0 \phi / \mathrm{kWh}$ \\
\hline
\end{tabular}




\section{8 - Competitive Green Power Offerings and Renewable Energy Certificates}

Green power marketing refers to selling green power in the competitive marketplace, in which multiple suppliers and service offerings exist. Electricity markets are now open to full competition in a number of states, while others are phasing-in competition, allowing some customers to choose their electricity supplier. As of mid-2004, competitive marketers offer green power to retail or wholesale customers in Maine, Maryland, Massachusetts, Pennsylvania, New Jersey, New York, Rhode Island, Texas, Virginia, and the District of Columbia (Figure 3.8.1).

Renewable energy certificates (RECs) - also known as green tags, renewable energy credits, or tradeable renewable certificates - present the environmental attributes of power generated from renewable electric plants. A number of organizations offer green energy certificates separate from electricity service (i.e. customers do not need to switch from their current electricity supplier to purchase these certificates). See our list below of organizations that offer green certificate products.

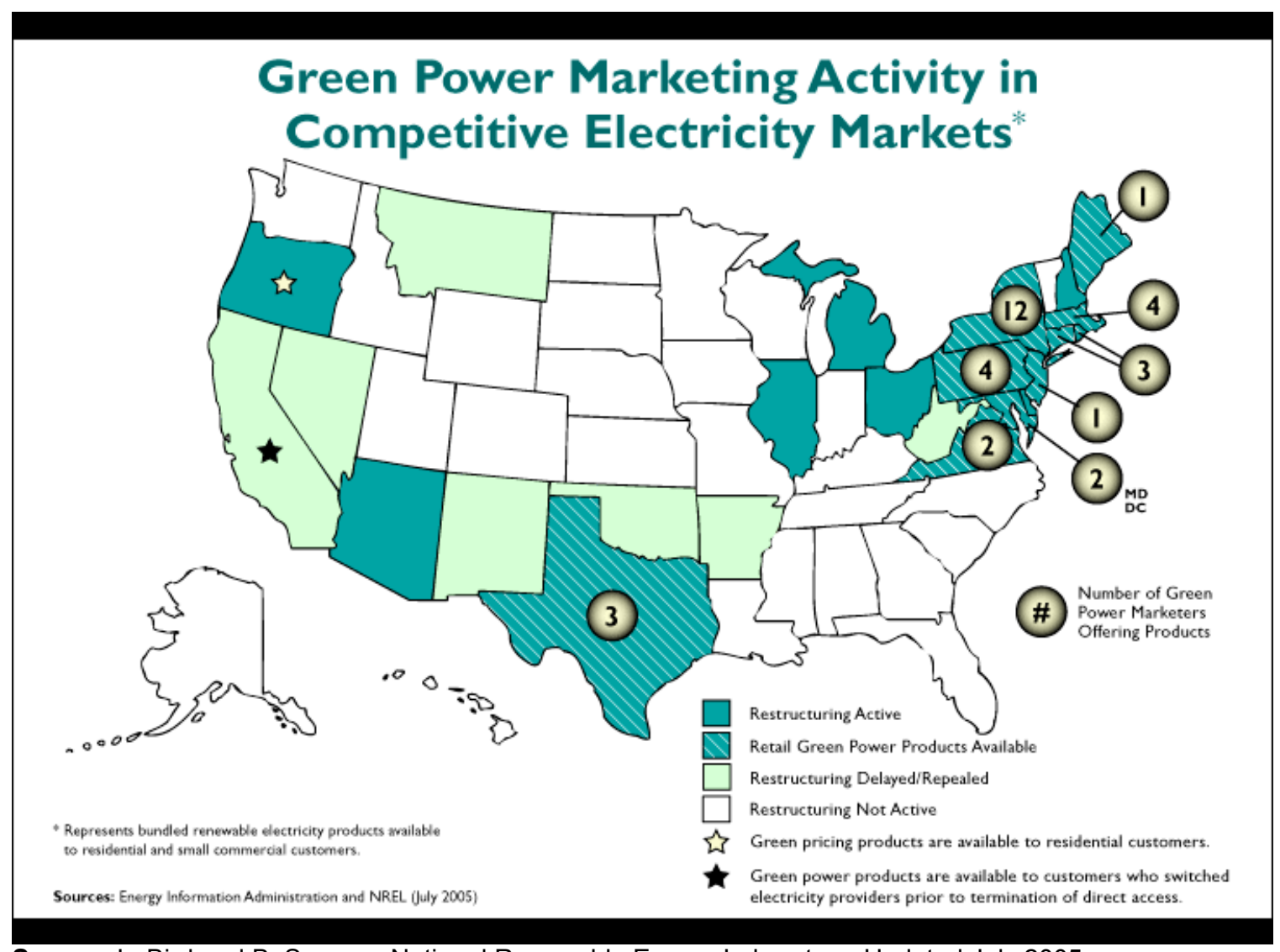

Source: L. Bird and B. Swezey, National Renewable Energy Laboratory. Updated July 2005. http://www.eere.energy.gov/greenpower/markets/marketing.shtml?page=4

Figure 3.8.1: Green Power Marketing Activity in Competitive Electricity Markets 
Based on data received from green power marketers, an estimated 200,000 retail customers were purchasing green power from competitive suppliers - or in the form of RECs - at the end of 2004. Most of these customers are purchasing green power from competitive suppliers in states with retail competition, primarily in the Northeast and Texas, including about 30,000 participants in utility/marketer programs. Of the total, fewer than 10,000 retail customers purchase REC products (Table 3.8.1), with most customers concentrated in the Mid-Atlantic and Northeast states where REC marketers tend to be most active. In competitive markets, the vast majority of customers purchasing green power are residential customers, while the fraction of nonresidential customers purchasing RECs is higher - on the order of one-fifth.

Table 3.8.1: Estimated Number of Customers Purchasing RECs or Green Power from Competitive Marketers, 2002-2004

\begin{tabular}{|l|c|c|c|}
\hline & \multicolumn{1}{|c|}{$\mathbf{2 0 0 2}$} & \multicolumn{1}{c|}{$\mathbf{2 0 0 3}$} & \multicolumn{1}{c|}{$\mathbf{2 0 0 4}$} \\
\hline Competitive Markets & $\sim 150,000$ & $>150,000$ & $>180,000$ \\
\hline RECs & $<10,000$ & $<10,000$ & $<10,000$ \\
\hline Total & $<160,000$ & $\sim 160,000$ & $\sim 190,000$ \\
\hline
\end{tabular}

Table 3.8.2: Retail Sales of Renewable Energy in Competitive Markets and RECs (million kWh)

\begin{tabular}{|l|l|c|}
\hline \multicolumn{2}{|c|}{2003} & 2004 \\
\hline Competitive Markets & na & 2,140 \\
\hline Residential & na & 510 \\
\hline Nonresidential & 1,900 & 2,650 \\
\hline Subtotal & na & 40 \\
\hline RECs & na & 1,690 \\
\hline Residential & 660 & 1,720 \\
\hline Nonresidential & 2,560 & 4,370 \\
\hline Subtotal &
\end{tabular}

na $=$ not available

An estimated 1,530 MW of new renewables capacity is used to supply competitive green power markets, or is being sold as RECs in both retail and wholesale markets; wind energy is the predominant resource type. More than $225 \mathrm{MW}$ of additional renewables capacity is planned, again dominated by wind.

An estimated 4.4 billion $\mathrm{kWh}$ of renewable energy was sold to retail customers by competitive and REC marketers. About 2.7 billion kWh of this total was sold to retail customers bundled with electricity in competitive electricity markets - a 40\% increase from 2003. This figure includes renewable energy from both existing and new sources, as well as that sold to customers in products that contain only a small percentage of renewable energy. It also includes sales of renewable energy through default utility/supplier programs or utility/marketer partnership in states with retail competition, 
which totaled 136 million $\mathrm{kWh}$. Retail sales of RECs, which are sold separate from electricity and largely derived from new renewable energy sources, grew nearly threefold, reaching 1.7 billion $\mathrm{kWh}$ in 2004.

Table 3.8.3: New Renewables Capacity Supplying Competitive Markets and Renewable Energy Certificates, 2004

\begin{tabular}{|l|c|c|c|c|}
\hline \multicolumn{1}{|c|}{ Source } & MW in Place & $\mathbf{\%}$ & MW Planned & \% \\
\hline Wind & $1,461.6$ & 95.7 & 224.8 & 99.3 \\
\hline Biomass & 59.3 & 3.9 & 1.3 & 0.6 \\
\hline Solar & 2.0 & 0.1 & 0.2 & 0.1 \\
\hline Geothermal & 5.0 & 0.3 & 0.0 & 0.0 \\
\hline Small Hydro & 0.0 & 0.0 & 0.0 & 0.0 \\
\hline Total & $1,527.9$ & 100.0 & 226.3 & 100.0 \\
\hline
\end{tabular}

Source: L.Bird and B. Swezey, Estimates of New Renewable Energy Capacity

Serving U.S. Green Power Markets (2004), National Renewable Energy Laboratory, September 2005. http://www.eere.energy.gov/greenpower/resources/tables/new_gp_cap.shtml

Table 3.8.4: Estimated Wholesale RECs Supplying Voluntary Markets, 2003

\begin{tabular}{|c|c|c|}
\hline & $\begin{array}{c}\text { Retail Sales } \\
\text { Millions of MWh }\end{array}$ & $\begin{array}{l}\text { Estimated RECs Sales } \\
\text { Millions of MWh }\end{array}$ \\
\hline Utility Green Pricing & 1.3 & 0.4 \\
\hline Competitive Markets & 1.9 & 1.9 \\
\hline Unbundled RECs & 0.7 & 0.7 \\
\hline Total Green Power Market & 3.9 & 3.0 \\
\hline
\end{tabular}

Source: L. Bird, NREL, 2004

Table 3.8.5: Voluntary Market REC Retirements in Texas and NEPOOL

\begin{tabular}{|l|r|rr|}
\hline Year & \multicolumn{2}{|c|}{$\begin{array}{c}\text { Texas Voluntary REC } \\
\text { Retirements } \\
\text { (MWh) }\end{array}$} & \multicolumn{2}{|c|}{$\begin{array}{c}\text { NEPOOL Voluntary REC } \\
\text { Retirements } \\
\text { (MWh) }\end{array}$} \\
\hline 2001 & & N/a & 0 \\
\hline 2002 & & 241,000 & 112,973 \\
\hline 2003 & & 797,000 & 56,905 \\
\hline
\end{tabular}

Sources: ERCOT 2004; NEPOOL GIS 
Table 3.8.6: Voluntary Market Wholesale REC Prices for New Sources by Type and Region (\$/MWh)

\begin{tabular}{|l|l|l|l|l|}
\hline & \multicolumn{1}{|c|}{ Wind } & \multicolumn{1}{c|}{ Solar } & \multicolumn{1}{c|}{ Biomass } & Small Hydro \\
\hline CA & $1.75-2.00$ & & 1.50 & \\
\hline WECC & $1.25-7.50$ & $30.00-150.00$ & $1.50-3.50$ & \\
\hline Central & $2.00-5.50$ & & 1.50 & \\
\hline PJM & $15.00-17.00$ & $80.00-200.00$ & $4: 00-5.00$ & \\
\hline New York & $15.00-16.00$ & & 6.00 & \\
\hline NEPOOL & 35.00 & & 45.00 & 5.00 \\
\hline SPP & $2.50-5.00$ & & & \\
\hline Southeast & & & 3.50 & \\
\hline
\end{tabular}

Sources: Evolution Markets (data for July 2003 through October 2004) and GT Energy.

Table 3.8.7: Voluntary Market Wholesale REC Prices for Existing Sources by Type and Region (\$/MWh)

\begin{tabular}{|l|l|l|l|l|l|}
\hline & Biomass & Geothermal & Hydro & Small Hydro & LIHI Hydro \\
\hline WECC & $0.25-2.50$ & $1.00-3.50$ & & & \\
\hline Central & & & & & \\
\hline PJM & & & & & \\
\hline New York & $2.00-5.00$ & & $2.00-3.00$ & $1.00-3.50$ & \\
\hline NEPOOL & & & & $2.00-4.00$ & 6.00 \\
\hline Southeast & & & & & \\
\hline
\end{tabular}

Source: Evolution Markets. Data for July 2003 through October 2004. 
Table 3.8.8: Retail Green Power Product Offerings in Competitive Electricity Markets, October 2005

\begin{tabular}{|c|c|c|c|c|c|c|}
\hline State & Company & Product Name & $\begin{array}{l}\text { Residential } \\
\text { Price } \\
\text { Premium1 }\end{array}$ & Fee & Resource Mix2 & Certification \\
\hline CT & $\begin{array}{r}\text { Community Energy } \\
\text { (CT Clean Energy } \\
\text { Options Program) }\end{array}$ & $\begin{array}{r}\text { CT Clean Energy } \\
\text { Options } 50 \% \text { or } \\
100 \% \text { of usage }\end{array}$ & $1.1 \phi / \mathrm{kWh}$ & - & $\begin{array}{r}50 \% \text { new wind, } 50 \% \\
\text { landfill gas }\end{array}$ & - \\
\hline CT & Levco & $\begin{array}{l}100 \% \text { Renewable } \\
\text { Electricity Program }\end{array}$ & $0.0 \phi / \mathrm{kWh}$ & - & $\begin{array}{r}98 \% \text { waste-to- } \\
\text { energy and hydro } \\
\text { (Class II), } 2 \% \text { new } \\
\text { solar, wind, fuel } \\
\text { cells, and landfill } \\
\text { gas }\end{array}$ & - \\
\hline CT & \begin{tabular}{|r|} 
Sterling Planet (CT \\
Clean Energy Options \\
Program)
\end{tabular} & $\begin{array}{r}\text { Sterling Select } 50 \% \\
\text { or } 100 \% \text { of usage } \\
\end{array}$ & $1.15 \phi / \mathrm{kWh}$ & - & $\begin{array}{r}33 \% \text { new wind, } 33 \% \\
\text { existing small low } \\
\text { impact hydro, } 34 \% \\
\text { new landfill gas }\end{array}$ & - \\
\hline $\mathrm{DC}$ & $\begin{array}{r}\text { PEPCO Energy } \\
\text { Services (3) }\end{array}$ & $\begin{array}{r}\text { Green Electricity } \\
10 \%, 51 \% \text { or } 100 \% \\
\text { of usage }\end{array}$ & $\begin{array}{r}1.35 \phi / \mathrm{kWh} \text { (for } \\
100 \% \text { usage) }\end{array}$ & - & landfill gas & - \\
\hline DC & $\begin{array}{r}\text { PEPCO Energy } \\
\text { Services (3) }\end{array}$ & $\begin{array}{r}\text { NewWind Energy } \\
51 \% \text { or } 100 \% \text { of } \\
\text { usage }\end{array}$ & $\begin{array}{r}2.05 \not k W h \text { (for } \\
100 \% \text { usage) }\end{array}$ & - & new wind & - \\
\hline $\mathrm{DC}$ & $\begin{array}{r}\text { Washington Gas } \\
\text { Energy Services / } \\
\text { Community Energy }\end{array}$ & $\begin{array}{r}\text { New Wind Energy } \\
(5 \%, 10 \%, 25 \%, \\
50 \%, \text { or } 100 \% \text { of } \\
\text { usage })\end{array}$ & $2.5 \phi / \mathrm{kWh}$ & - & new wind & - \\
\hline $\mathrm{ME}$ & $\begin{array}{r}\text { Maine Renewable } \\
\text { Energy/Maine } \\
\text { Interfaith Power \& } \\
\text { Light (4) }\end{array}$ & Maine Clean Power & $2.37 \phi / \mathrm{kWh}$ & - & $\begin{array}{r}100 \% \text { low impact } \\
\text { hydro }\end{array}$ & - \\
\hline $\mathrm{ME}$ & $\begin{array}{r}\text { Maine Renewable } \\
\text { Energy/Maine } \\
\text { Interfaith Power \& } \\
\text { Light (4) }\end{array}$ & $\begin{array}{r}\text { Maine Clean Power } \\
\text { Plus }\end{array}$ & $2.87 \phi / \mathrm{kWh}$ & - & $\begin{array}{r}80 \% \text { low impact } \\
\text { hydro, } 20 \% \text { wind }\end{array}$ & - \\
\hline$M$ & $\begin{array}{r}\text { PEPCO Energy } \\
\text { Services (5) }\end{array}$ & $\begin{array}{r}\text { Green Electricity } \\
10 \%, 51 \% \text { or } 100 \% \\
\text { of usage }\end{array}$ & $\begin{array}{r}2.75 \phi / \mathrm{kWh} \text { (for } \\
100 \% \text { usage) }\end{array}$ & - & landfill gas & - \\
\hline MD & $\begin{array}{r}\text { PEPCO Energy } \\
\text { Services (5) }\end{array}$ & $\begin{array}{r}\text { NewWind Energy } \\
51 \% \text { or } 100 \% \text { of } \\
\text { usage }\end{array}$ & $\begin{array}{r}3.35 \phi / \mathrm{kWh} \text { (for } \\
100 \% \text { usage) }\end{array}$ & - & new wind & - \\
\hline MD & $\begin{array}{r}\text { PEPCO Energy } \\
\text { Services (5) }\end{array}$ & $\begin{array}{r}\text { Non-residential } \\
\text { product }\end{array}$ & NA & - & $\begin{array}{r}50 \% \text { to } 100 \% \\
\text { eligible renewables }\end{array}$ & Green-e \\
\hline $\mathrm{MD}$ & $\begin{array}{r}\text { Washington Gas } \\
\text { Energy Services / } \\
\text { Community Energy }\end{array}$ & New Wind Energy & $2.5 \phi / \mathrm{kWh}$ & - & $\begin{array}{r}\text { new wind }(5 \%, \\
10 \%, 25 \%, 50 \% \text {, or } \\
100 \% \text { of usage) or } \\
100 \text { kWh blocks }\end{array}$ & - \\
\hline MA & $\begin{array}{r}\text { Cape Light Compact } \\
(6)\end{array}$ & \begin{tabular}{|l|} 
Cape Light Compact \\
Green $50 \%$ or $100 \%$
\end{tabular} & $\begin{array}{r}1.768 \phi / \mathrm{kWh} \\
\text { (for } 100 \% \\
\text { usage) }\end{array}$ & - & $\begin{array}{r}75 \% \text { small hydro, } \\
24 \% \text { new wind or } \\
\text { landfill gas, } 1 \% \text { new } \\
\text { solar }\end{array}$ & - \\
\hline MA & $\begin{array}{r}\text { Massachusetts } \\
\text { Electric/Nantucket } \\
\text { Electric/Community } \\
\text { Energy }\end{array}$ & $\begin{array}{r}\text { New Wind Energy } \\
50 \% \text { or } 100 \% \text { of } \\
\text { usage }\end{array}$ & $2.4 \phi / \mathrm{kWh}$ & - & $\begin{array}{r}50 \% \text { small hydro, } \\
50 \% \text { new wind }\end{array}$ & Green-e \\
\hline
\end{tabular}




\begin{tabular}{|c|c|c|c|c|c|c|}
\hline State & Company & Product Name & $\begin{array}{l}\text { Residential } \\
\text { Price } \\
\text { Premium1 }\end{array}$ & Fee & Resource Mix2 & Certification \\
\hline $\mathrm{MA}$ & \begin{tabular}{|l|} 
Massachusetts \\
Electric/Nantucket \\
Electric/Mass Energy \\
Consumers Alliance
\end{tabular} & $\begin{array}{l}\text { New England } \\
\text { GreenStart } 50 \% \text { or } \\
100 \% \text { of usage }\end{array}$ & $\begin{array}{l}2.4 \phi / \mathrm{kWh} \text { (for } \\
100 \% \text { usage) }\end{array}$ & - & $\begin{array}{l}75 \% \text { small hydro, } \\
19 \% \text { biomass, } 5 \% \\
\text { wind, } 1 \% \text { solar } \\
(\geq 25 \% \text { of total is } \\
\text { new) }\end{array}$ & - \\
\hline MA & $\begin{array}{l}\text { Massachusetts } \\
\text { Electric/Nantucket } \\
\text { Electric/Sterling } \\
\text { Planet }\end{array}$ & $\begin{array}{l}\text { Sterling Premium } \\
50 \% \text { or } 100 \% \text { of } \\
\text { usage }\end{array}$ & $1.35 \phi / \mathrm{kWh}$ & - & $\begin{array}{l}50 \% \text { small hydro, } \\
30 \% \text { bioenergy, } \\
15 \% \text { wind, } 5 \% \text { new } \\
\text { solar }\end{array}$ & \begin{tabular}{|l} 
Environmenta \\
Resources \\
Trust
\end{tabular} \\
\hline $\mathrm{NJ}$ & \begin{tabular}{|l} 
Green Mountain \\
Energy Company (7)
\end{tabular} & Enviro Blend & $1.0 \phi / \mathrm{kWh}$ & $\$ 3.95 / \mathrm{mo}$. & $\begin{array}{l}5 \% \text { new wind, } 0.4 \% \\
\text { solar, } 44.6 \% \\
\text { captured methane, } \\
50 \% \text { large hydro }\end{array}$ & - \\
\hline $\mathrm{NJ}$ & $\begin{array}{l}\text { PSE\&G/JCP\&L/ } \\
\text { Community Energy }\end{array}$ & $\begin{array}{l}\text { Clean Power Choice } \\
\text { Program }\end{array}$ & $1.3 \phi / \mathrm{kWh}$ & - & $\begin{array}{l}50 \% \text { wind, } 49 \% \text { low } \\
\text { impact hydro, } 1 \% \\
\text { solar }\end{array}$ & - \\
\hline $\mathrm{NJ}$ & $\begin{array}{l}\text { PSE\&G/JCP\&L/ } \\
\text { Green Mountain } \\
\text { Energy }\end{array}$ & $\begin{array}{l}\text { Clean Power Choice } \\
\text { Program }\end{array}$ & $0.9 \phi / \mathrm{kWh}$ & - & $\begin{array}{l}50 \% \text { wind, } 50 \% \text { low } \\
\text { impact hydro }\end{array}$ & - \\
\hline $\mathrm{NJ}$ & $\begin{array}{l}\text { PSE\&G/JCP\&L/ } \\
\text { Jersey-Atlantic Wind }\end{array}$ & $\begin{array}{l}\text { Clean Power Choice } \\
\text { Program }\end{array}$ & $2.9 \phi / \mathrm{kWh}$ & - & $\begin{array}{l}50 \% \text { wind, } 50 \% \text { low } \\
\text { impact hydro }\end{array}$ & - \\
\hline $\mathrm{NJ}$ & \begin{tabular}{|l} 
PSE\&G/JCP\&L/ \\
Jersey-Atlantic Wind
\end{tabular} & $\begin{array}{l}\text { Clean Power Choice } \\
\text { Program: New } \\
\text { Jersey Wind Energy }\end{array}$ & $5.5 \phi / \mathrm{kWh}$ & - & 100-kWh new wind & - \\
\hline$\overline{\mathrm{NJ}}$ & $\begin{array}{l}\text { PSE\&G/JCP\&L/ } \\
\text { Sterling Planet }\end{array}$ & $\begin{array}{l}\text { Clean Power Choice } \\
\text { Program }\end{array}$ & $1.2 \phi / \mathrm{kWh}$ & - & $\begin{array}{l}33 \% \text { wind, } 33 \% \\
\text { small hydro, } 34 \% \\
\text { bioenergy }\end{array}$ & $\begin{array}{l}\text { Environmenta } \\
\text { Resources } \\
\text { Trust }\end{array}$ \\
\hline NY & $\begin{array}{l}\text { ConEdison Solutions } \\
\text { (8) / Community } \\
\text { Energy }\end{array}$ & GREEN Power & $0.5 \phi / \mathrm{kWh}$ & - & $\begin{array}{l}25 \% \text { new wind, } \\
75 \% \text { small hydro }\end{array}$ & Green-e \\
\hline$\overline{N Y}$ & ECONnergy & Keet It Clean & $\begin{array}{l}\$ .10 / \text { day for } \\
100 \mathrm{kWh} \\
\$ .20 / \text { day for } \\
200 \mathrm{kWh}\end{array}$ & - & $100 \%$ new wind & - \\
\hline NY & $\begin{array}{l}\text { Energy Cooperative of } \\
\text { New York (9) }\end{array}$ & $\begin{array}{l}\text { fenewable } \\
\text { Electricity }\end{array}$ & $\begin{array}{l}0.5 \phi / \mathrm{kWh} \text { to } \\
0.75 \phi / \mathrm{kWh}\end{array}$ & - & $\begin{array}{l}25 \% \text { new wind, } \\
75 \% \text { existing landfill } \\
\text { gas }\end{array}$ & - \\
\hline$\overline{N Y}$ & $\begin{array}{l}\text { Long Island Power } \\
\text { Authority / Community } \\
\text { Energy }\end{array}$ & New Wind Energy & $2.5 \phi / \mathrm{kWh}$ & - & new wind & - \\
\hline NY & $\begin{array}{l}\text { Long Island Power } \\
\text { Authority / Community } \\
\text { Energy }\end{array}$ & $\begin{array}{l}\text { New Wind Energy } \\
\text { and Water }\end{array}$ & $1.3 \phi / \mathrm{kWh}$ & - & $\begin{array}{l}60 \% \text { new wind, } \\
40 \% \text { small hydro }\end{array}$ & - \\
\hline NY & $\begin{array}{l}\text { Long Island Power } \\
\text { Authority / EnviroGen }\end{array}$ & $\begin{array}{l}\text { Green Power } \\
\text { Program }\end{array}$ & $1.0 \phi / \mathrm{kWh}$ & - & $\begin{array}{l}75 \% \text { landfill gas, } \\
25 \% \text { small hydro }\end{array}$ & - \\
\hline$\overline{N Y}$ & $\begin{array}{l}\text { Long Island Power } \\
\text { Authority / Sterling } \\
\text { Planet }\end{array}$ & New York Clean & $1.0 \phi / \mathrm{kWh}$ & - & $\begin{array}{l}55 \% \text { small hydro, } \\
35 \% \text { bioenergy, } \\
10 \% \text { wind }\end{array}$ & - \\
\hline NY & $\begin{array}{l}\text { Long Island Power } \\
\text { Authority / Sterling } \\
\text { Planet }\end{array}$ & Sterling Green & $1.5 \phi / \mathrm{kWh}$ & - & $\begin{array}{l}40 \% \text { wind, } 30 \% \\
\text { small hydro, } 30 \% \\
\text { bioenergy }\end{array}$ & - \\
\hline NY & $\begin{array}{l}\text { NYSEG/Community } \\
\text { Energy }\end{array}$ & $\begin{array}{l}\text { Catch the Wind/New } \\
\text { Wind Energy }\end{array}$ & $2.5 \phi / \mathrm{kWh}$ & - & $\begin{array}{l}\text { 100-kWh blocks of } \\
\text { new wind }\end{array}$ & - \\
\hline
\end{tabular}




\begin{tabular}{|c|c|c|c|c|c|c|}
\hline State & Company & Product Name & $\begin{array}{l}\text { Residential } \\
\text { Price } \\
\text { Premium1 }\end{array}$ & Fee & Resource Mix2 & Certification \\
\hline$\overline{N Y}$ & $\begin{array}{l}\text { Niagara Mohawk / } \\
\text { Community Energy }\end{array}$ & $\begin{array}{l}60 \% \text { New Wind } \\
\text { Energy and } 40 \% \\
\text { Small Hydro }\end{array}$ & $1.0 \phi / \mathrm{kWh}$ & - & $\begin{array}{l}60 \% \text { new wind, } \\
40 \% \text { hydro }\end{array}$ & - \\
\hline$\overline{N Y}$ & $\begin{array}{l}\text { Niagara Mohawk / } \\
\text { Community Energy }\end{array}$ & NewWind Energy & $2.0 \phi / \mathrm{kWh}$ & - & new wind & - \\
\hline NY & $\begin{array}{l}\text { Niagara Mohawk / } \\
\text { EnviroGen }\end{array}$ & Think Green! & $1.0 \phi / \mathrm{kWh}$ & - & $\begin{array}{l}75 \% \text { landfill gas, } \\
25 \% \text { hydro }\end{array}$ & - \\
\hline NY & $\begin{array}{l}\text { Niagara Mohawk / } \\
\text { Sterling Planet }\end{array}$ & Sterling Green & $1.5 \phi / \mathrm{kWh}$ & - & $\begin{array}{l}40 \% \text { wind, } 30 \% \\
\text { small hydro, } 30 \% \\
\text { bioenergy }\end{array}$ & \begin{tabular}{|l|} 
Environmental \\
Resources \\
Trust
\end{tabular} \\
\hline $\mathrm{NY}$ & \begin{tabular}{|l} 
Niagara \\
Mohawk/Green \\
Mountain Energy
\end{tabular} & $\begin{array}{l}\text { Green Mountain } \\
\text { Energy Electricity }\end{array}$ & $1.3 \phi / \mathrm{kWh}$ & - & $\begin{array}{l}50 \% \text { small hydro, } \\
50 \% \text { wind }\end{array}$ & Green-e \\
\hline NY & $\begin{array}{l}\text { Rochester Gas \& } \\
\text { Electric/Community } \\
\text { Energy }\end{array}$ & $\begin{array}{l}\text { Catch the } \\
\text { Wind/NewWind } \\
\text { Energy }\end{array}$ & $2.5 \phi / \mathrm{kWh}$ & - & $\begin{array}{l}\text { 100-kWh blocks of } \\
\text { new wind }\end{array}$ & - \\
\hline$\overline{N Y}$ & $\begin{array}{l}\text { Suburban Energy } \\
\text { Services /Sterling } \\
\text { Planet }\end{array}$ & \begin{tabular}{|l|} 
Sterling Green \\
Renewable \\
Electricity
\end{tabular} & $1.5 \phi / \mathrm{kWh}$ & - & $\begin{array}{l}40 \% \text { new wind, } \\
30 \% \text { small hydro, } \\
30 \% \text { bioenergy }\end{array}$ & - \\
\hline $\mathrm{PA}$ & $\begin{array}{l}\text { Energy Cooperative of } \\
\text { Pennsylvania (10) }\end{array}$ & EcoChoice 100 & $2.78 \phi / \mathrm{kWh}$ & - & $\begin{array}{l}89 \% \text { landfill gas, } \\
10 \% \text { wind, } 1 \% \text { solar }\end{array}$ & Green-e \\
\hline PA & $\begin{array}{l}\text { Energy Cooperative of } \\
\text { Pennsylvania (10) }\end{array}$ & Wind Energy & $2.5 \phi / \mathrm{kWh}$ & - & wind & - \\
\hline PA & \begin{tabular}{|l} 
PECO \\
Energy/Community \\
Energy (10)
\end{tabular} & PECO Wind & $2.54 \phi / \mathrm{kWh}$ & - & $\begin{array}{l}\text { 100-kWh blocks of } \\
\text { new wind }\end{array}$ & - \\
\hline PA & $\begin{array}{l}\text { PEPCO Energy } \\
\text { Services (10) }\end{array}$ & $\begin{array}{l}\text { Green Electricity } \\
10 \%, 51 \% \text { or } 100 \% \\
\text { of usage }\end{array}$ & $\begin{array}{l}3.7 \phi / \mathrm{kWh} \text { (for } \\
100 \% \text { usage) }\end{array}$ & - & $100 \%$ renewable & - \\
\hline $\mathrm{PA}$ & $\begin{array}{l}\text { PEPCO Energy } \\
\text { Services (10) }\end{array}$ & $\begin{array}{l}\text { NewWind Energy } \\
51 \% \text { or } 100 \% \text { of } \\
\text { usage }\end{array}$ & $\begin{array}{l}4.48 \phi / \mathrm{kWh} \text { (for } \\
100 \% \text { usage) }\end{array}$ & - & $100 \%$ new wind & - \\
\hline $\mathrm{RI}$ & $\begin{array}{l}\text { Narragansett Electric / } \\
\text { Community Energy, } \\
\text { Inc. }\end{array}$ & $\begin{array}{l}\text { NewWind Energy } \\
50 \% \text { or } 100 \% \text { of } \\
\text { usage }\end{array}$ & $2.0 \phi / \mathrm{kWh}$ & - & $\begin{array}{l}50 \% \text { small hydro, } \\
50 \% \text { new wind }\end{array}$ & Green-e \\
\hline $\mathrm{RI}$ & $\begin{array}{l}\text { Narragansett Electric / } \\
\text { People's Power \& } \\
\text { Light }\end{array}$ & \begin{tabular}{|l} 
New England \\
GreenStart RI $50 \%$ \\
or $100 \%$ of usage
\end{tabular} & $1.5 \phi / \mathrm{kWh}$ & - & $\begin{array}{l}69 \% \text { small hydro, } \\
30 \% \text { new wind, } 1 \% \\
\text { new solar }\end{array}$ & Green-e \\
\hline $\mathrm{RI}$ & $\begin{array}{l}\text { Narragansett Electric / } \\
\text { Sterling Planet }\end{array}$ & $\begin{array}{l}\text { Sterling Supreme } \\
100 \%\end{array}$ & $1.98 \phi / \mathrm{kWh}$ & - & $\begin{array}{l}40 \% \text { small hydro, } \\
25 \% \text { biomass, } 25 \% \\
\text { new solar, } 10 \% \\
\text { wind }\end{array}$ & \begin{tabular}{|l} 
Environmental \\
Resources \\
Trust
\end{tabular} \\
\hline TX & Gexa Energy (11) & Gexa Green & $-1.1 \phi / \mathrm{kWh}$ & - & $100 \%$ renewable & - \\
\hline$T \mathrm{TX}$ & \begin{tabular}{|l} 
Green Mountain \\
Energy Company (11)
\end{tabular} & $\begin{array}{l}\text { 100\% Wind Power: } \\
\text { Reliable Rate or } \\
\text { Month-to-Month }\end{array}$ & $1.46 \phi / \mathrm{kWh}$ & $\$ 5.34 / \mathrm{mo}$. & wind & - \\
\hline$T \mathrm{TX}$ & \begin{tabular}{|l} 
Green Mountain \\
Energy Company (11)
\end{tabular} & $\begin{array}{l}\text { Pollution Free: } \\
\text { Reliable Rate or } \\
\text { Month-to-Month }\end{array}$ & $-0.03 \phi / \mathrm{kWh}$ & $\$ 5.34 / \mathrm{mo}$. & wind and hydro & - \\
\hline TX & Reliant Energy (11) & Renewable Plan & $-1.1 \phi / \mathrm{kWh}$ & - & wind & - \\
\hline VA & $\begin{array}{l}\text { PEPCO Energy } \\
\text { Services (12) }\end{array}$ & \begin{tabular}{|l|} 
Green Electricity \\
$10 \%, 51 \%$ or $100 \%$ \\
of usage
\end{tabular} & $\begin{array}{l}4.53 \phi / \mathrm{kWh} \text { (for } \\
100 \% \text { usage) }\end{array}$ & - & landfill gas & - \\
\hline
\end{tabular}




\begin{tabular}{|l|l|l|l|l|l|l|}
\hline State & \multicolumn{1}{|c|}{ Company } & Product Name & $\begin{array}{l}\text { Residential } \\
\text { Price } \\
\text { Premium1 }\end{array}$ & Fee & Resource Mix2 & Certification \\
\hline VA & $\begin{array}{l}\text { PEPCO Energy } \\
\text { Services (12) }\end{array}$ & $\begin{array}{l}\text { NewWind Energy } \\
51 \% \text { or } 100 \% \text { of } \\
\text { usage }\end{array}$ & $\begin{array}{l}5.33 \phi / \mathrm{kWh}(\mathrm{for}- \\
100 \% \text { usage) }\end{array}$ & new wind & - \\
\hline VA & $\begin{array}{l}\text { Washington Gas } \\
\text { Energy Services / } \\
\text { Community Energy }\end{array}$ & $\begin{array}{l}\text { New Wind Energy } \\
\text { Certificates }\end{array}$ & $2.5 \phi / \mathrm{kWh}$ & - & $\begin{array}{l}100 \mathrm{kWh} \text { blocks of } \\
\text { new wind }\end{array}$ & - \\
\hline
\end{tabular}

1 Prices updated as of July 2005 and may also apply to small commercial customers. Prices may differ for large commercial/industrial customers and may vary by service territory.

2 New is defined as operating or repowered after January 1, 1999 based on the Green-e TRC certification standards.

3 Offered in PEPCO service territory. Product prices are for renewal customers based on annual average costs for customers in PEPCO's service territory $(6.8 \phi / \mathrm{kWh})$.

4 Price premium is for Central Maine Power service territory based on standard offer of $7.13 \phi / \mathrm{kWh}$.

5 Product offered in Baltimore Gas and Electric and PEPCO service territories. Price is for PEPCO service territory based on price to compare of $6.55 \phi / \mathrm{kWh}$.

6 Price premium is based on a comparison to the Cape Light Compact's standard electricity product.

7 Green Mountain Energy offers products in Conectiv, JCPL, and PSE\&G service territories. Product prices are for PSE\&G (price to compare of $6.503 \phi / \mathrm{kWh}$ ).

8 Price premium is based on a comparison to ConEdison Solutions' standard electricity product in the ConEdison service territory.

9 Price premium is for Niagara Mohawk service territory. Program only available in Niagara Mohawk service territory. Premium varies depending on energy taxes and usage.

10 Product prices are for PECO service territory (price to compare of $6.21 \mathrm{\phi} / \mathrm{kWh}$ ).

11 Product prices are based on price to beat of $12.1 \phi / \mathrm{kWh}$ for TXU service territory (specifically Dallas,

Texas) (Except where noted). Except for Gexa Green, which is listed in price per kWh, prices based on 1000 kwh of usage monthly, and include monthly fees.

12 Products are available in Dominion Virginia Power service territory 
Table 3.8.9: Renewable Energy Certificate (REC) Retail Products, October 2005

\begin{tabular}{|c|c|c|c|c|c|}
\hline Certificate Marketer & Product Name & $\begin{array}{l}\text { Renewable } \\
\text { Resources }\end{array}$ & $\begin{array}{l}\text { Location of } \\
\text { Renewable } \\
\text { Resources }\end{array}$ & $\begin{array}{l}\text { Residential } \\
\text { Price } \\
\text { Premiums* }\end{array}$ & Certification \\
\hline 3 Phases Energy Services & $\begin{array}{l}\text { Green } \\
\text { Certificates }\end{array}$ & $100 \%$ new wind & Nationwide & $2.0 \phi / \mathrm{kWh}$ & Green-e \\
\hline Blue Sky Energy Corp & $\begin{array}{l}\text { Greener } \\
\text { Choice }^{\mathrm{TM}} \text { Green } \\
\text { Tags }\end{array}$ & Landfill Gas & Utah & $1.95 \phi / \mathrm{kWh}$ & - \\
\hline $\begin{array}{l}\text { Bonneville Environmental } \\
\text { Foundation }\end{array}$ & Green Tags & $\begin{array}{l}\geq 98 \% \text { new } \\
\text { wind, } \leq 1 \% \text { new } \\
\text { solar, } \leq 1 \% \text { new } \\
\text { biomass }\end{array}$ & $\begin{array}{l}\text { Washington, } \\
\text { Oregon, } \\
\text { Wyoming, } \\
\text { Montana, Alberta }\end{array}$ & $2.0 \phi / \mathrm{kWh}$ & Green-e \\
\hline Clean and Green & $\begin{array}{l}\text { Clean and Green } \\
\text { Membership }\end{array}$ & $100 \%$ new wind & National & $3.0 \phi / \mathrm{kWh}$ & Green-e \\
\hline $\begin{array}{l}\text { Clean Energy } \\
\text { Partnership/Community } \\
\text { Energy }\end{array}$ & Mid Atlantic Wind & $100 \%$ new wind & Mid Atlantic & $2.0 \phi / \mathrm{kWh}$ & Green-e \\
\hline \begin{tabular}{|l|} 
Clean Energy \\
Partnership/Sterling Planet
\end{tabular} & $\begin{array}{l}\text { National New } \\
\text { Clean Energy Mlx }\end{array}$ & $\begin{array}{l}24 \% \text { wind, } 25 \% \\
\text { biomass, } 50 \% \\
\text { landfill gas, } 1 \% \\
\text { solar }\end{array}$ & National & $0.6 \phi / \mathrm{kWh}$ & $\begin{array}{l}\text { Environmental } \\
\text { Resources Trust }\end{array}$ \\
\hline $\begin{array}{l}\text { Clean Energy } \\
\text { Partnership/Sterling Planet }\end{array}$ & $\begin{array}{l}\text { National and } \\
\text { Regional New } \\
\text { Wind }\end{array}$ & $100 \%$ new wind & National & $1.0 \phi / \mathrm{kWh}$ & $\begin{array}{l}\text { Environmental } \\
\text { Resources Trust }\end{array}$ \\
\hline Community Energy & $\begin{array}{l}\text { New Wind } \\
\text { Energy }\end{array}$ & $100 \%$ new wind & \begin{tabular}{|l|} 
Colorado, Illinois, \\
New York, \\
Pennsylvania, \\
West Virginia
\end{tabular} & $\begin{array}{l}2.0 \phi / \mathrm{kWh}- \\
2.5 \phi / \mathrm{kWh}\end{array}$ & Green-e \\
\hline $\begin{array}{l}\text { Conservation Services } \\
\text { Group }\end{array}$ & ClimateSAVE & $\begin{array}{l}95 \% \text { new wind, } \\
5 \% \text { new solar }\end{array}$ & $\begin{array}{l}\text { Kansas (wind), } \\
\text { New York (solar) }\end{array}$ & $\begin{array}{l}1.65 \phi / \mathrm{kWh}- \\
1.75 \phi / \mathrm{kWh}\end{array}$ & Green-e \\
\hline EAD Environmental & $\begin{array}{l}100 \% \text { Wind } \\
\text { Energy } \\
\text { Certificates }\end{array}$ & $100 \%$ new wind & Not specified & $1.5 \phi / \mathrm{kWh}$ & - \\
\hline EAD Environmental & $\begin{array}{l}\text { Home Grown } \\
\text { Hydro Certificates }\end{array}$ & $\begin{array}{l}100 \% \text { small } \\
\text { hydro }(<5 \mathrm{MW})\end{array}$ & New England & $1.2 \phi / \mathrm{kWh}$ & - \\
\hline Green Mountain Energy & $\begin{array}{l}\text { TBD } \\
\text { (Pennsylvania } \\
\text { REC product) } \\
\end{array}$ & $100 \%$ wind & National & $\begin{array}{l}1.7 \phi / \mathrm{kWh}- \\
2.0 \phi / \mathrm{kWh}\end{array}$ & - \\
\hline $\begin{array}{l}\text { Maine Interfaith Power \& } \\
\text { Light/BEF }\end{array}$ & $\begin{array}{l}\text { Green Tags } \\
\text { (supplied by BEF) }\end{array}$ & $\begin{array}{l}\geq 98 \% \text { new } \\
\text { wind, } \leq 1 \% \text { new } \\
\text { solar, } \leq 1 \% \text { new } \\
\text { biomass }\end{array}$ & \begin{tabular}{|l|} 
Washington, \\
Oregon, \\
Wyoming, \\
Montana, Alberta
\end{tabular} & $2.0 \phi / \mathrm{kWh}$ & - \\
\hline $\begin{array}{l}\text { Mass Energy Consumers } \\
\text { Alliance }\end{array}$ & $\begin{array}{l}\text { New England } \\
\text { Wind }\end{array}$ & $100 \%$ new wind & Massachusetts & $5.0 \phi / \mathrm{kWh}$ & - \\
\hline NativeEnergy & CoolHome & $\begin{array}{l}\text { New biogas and } \\
\text { new wind }\end{array}$ & $\begin{array}{l}\text { Vermont and } \\
\text { Pennsylvania } \\
\text { (biomass), South } \\
\text { Dakota (wind) }\end{array}$ & $\begin{array}{l}0.8 \phi / \mathrm{kWh}- \\
1.0 \phi / \mathrm{kWh}\end{array}$ & ** \\
\hline NativeEnergy & WindBuilders & $100 \%$ new wind & South Dakota & $\begin{array}{l}\sim 1.2 \phi / \mathrm{kWh}, \\
\$ 12 \text { per ton of } \\
\text { CO2 avoided }\end{array}$ & ** \\
\hline Renewable Choice Energy & American Wind & $100 \%$ new wind & Nationwide & $2.0 \phi / \mathrm{kWh}$ & Green-e \\
\hline
\end{tabular}




\begin{tabular}{|c|c|c|c|c|c|}
\hline Certificate Marketer & Product Name & $\begin{array}{l}\text { Renewable } \\
\text { Resources }\end{array}$ & $\begin{array}{l}\text { Location of } \\
\text { Renewable } \\
\text { Resources }\end{array}$ & $\begin{array}{l}\text { Residential } \\
\text { Price } \\
\text { Premiums* }\end{array}$ & Certification \\
\hline Renewable Ventures & $\begin{array}{l}\text { PVUSA Solar } \\
\text { Green } \\
\text { Certificates }\end{array}$ & $100 \%$ solar & California & $3.3 \phi / \mathrm{kWh}$ & Green-e \\
\hline SKY energy, Inc. & $\begin{array}{l}\text { Wind-e } \\
\text { Renewable } \\
\text { Energy }\end{array}$ & $100 \%$ new wind & Nationwide & $2.4 \phi / \mathrm{kWh}$ & Green-e \\
\hline Sterling Planet & Green America & \begin{tabular}{|l|}
$45 \%$ new wind, \\
$50 \%$ new \\
biomass, $5 \%$ \\
new solar
\end{tabular} & Nationwide & $1.6 \phi / \mathrm{kWh}$ & Green-e \\
\hline TerraPass Inc. & TerraPass & $\begin{array}{l}\text { Various } \\
\text { (including } \\
\text { efficiency and } \\
\text { CO2 offsets) }\end{array}$ & Nationwide & $\sim \$ 11 /$ ton CO2 & - \\
\hline Waverly Light \& Power & $\begin{array}{l}\text { lowa Energy } \\
\text { Tags }\end{array}$ & $100 \%$ wind & lowa & $2.0 \phi / \mathrm{kWh}$ & - \\
\hline WindCurrent & $\begin{array}{l}\text { Chesapeake } \\
\text { Windcurrent }\end{array}$ & $100 \%$ new wind & $\begin{array}{l}\text { Mid-Atlantic } \\
\text { States }\end{array}$ & $2.5 \phi / \mathrm{kWh}$ & Green-e \\
\hline
\end{tabular}

Premium may also apply to small commercial customers. Large users may be able to negotiate price premiums.

Most product prices are as of July 2005.

** The Climate Neutral Network certifies the methodology used to calculate the $\mathrm{CO} 2$ emissions offset. $\mathrm{NA}=$ Not applicable. 


\section{9 - Federal Agency Purchases of Green Power}

The federal government exceeded its goal of obtaining $2.5 \%$ of its electricity needs from renewable energy sources by September 30, 2005. The federal renewable energy goal was established under Executive Order 13123, issued by President Clinton in 1999. The federal government, which is the nation's largest energy consumer, purchases 2.375 billion $\mathrm{kWh}$ of renewable energy annually.

The Energy Policy Act of 2005, signed into law by President Bush on August 8, 2005, establishes a new set of federal renewable energy goals, calling for agencies to derive $3 \%$ of their electric energy from renewable sources in fiscal years 2007 through 2009, increasing to 5\% in fiscal years 2010 through 2012, and 7.5\% by 2013 and each fiscal year thereafter. 


\subsection{0 - State Incentive Programs}

Many states have policies or programs in place to support renewable energy resources, such as tax incentives; industry recruitment incentives; or grant, loan, or rebate programs. The following table lists the incentives currently available by state (Table 3.10.1).

\section{Table 3.10.1 Financial Incentives for Renewable Energy Resources by State}

\begin{tabular}{|c|c|c|}
\hline State & Tax Incentives & Grants, Loans, Rebates and Other Incentives \\
\hline $\mathrm{AL}$ & $\begin{array}{l}\text { Wood-Burning Heating System } \\
\text { Deduction (Personal) }\end{array}$ & $\begin{array}{l}\text { Renewable Fuels Development Program (Biomass, Municipal Solid } \\
\text { Waste) }\end{array}$ \\
\hline AK & & Power Project Loan Fund \\
\hline$A Z$ & $\begin{array}{l}\text { Qualifying Wood Stove Deduction; } \\
\text { Solar and Wind Energy Systems } \\
\text { Credit (Personal); Solar and Wind } \\
\text { Equipment Sales Tax Exemption } \\
\text { (Personal) }\end{array}$ & $\begin{array}{l}\text { APS - EPS Credit Purchase Program; SRP - Earthwise Solar } \\
\text { Energy; TEP - SunShare PV Buydown; UES - SunShare PV } \\
\text { Buydown }\end{array}$ \\
\hline \multicolumn{3}{|c|}{ 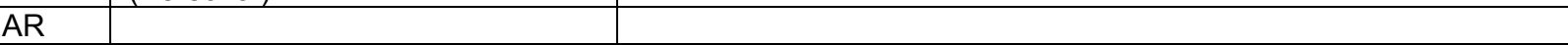 } \\
\hline $\mathrm{CA}$ & $\begin{array}{l}\text { Solar or Wind Energy System } \\
\text { Credit - Personal; Tax Deduction } \\
\text { for Interest on Loans for Energy } \\
\text { Efficiency; Solar or Wind Energy } \\
\text { System Credit - Corporate; } \\
\text { California Property Tax Exemption } \\
\text { for Solar Systems }\end{array}$ & $\begin{array}{l}\text { Emerging Renewable (Rebate) Program; SELFGEN - SELF- } \\
\text { Generation Program; Anaheim Public Utilities - PV Buydown } \\
\text { Program; Burbank Water \& Power - Residential \& Commercial } \\
\text { Solar Support; City of Palo Alto Utilities - PV Partners; Glendale } \\
\text { Water \& Power - Solar Solutions Program; IID Energy - PV } \\
\text { Solutions Rebate Program; LADWP - Solar Incentive Program; } \\
\text { Pasadena Water and Power - Solar Power Installation Rebate; } \\
\text { Redding Electric - Earth Vantage Renewable Energy Rebate } \\
\text { Program; Riverside Public Utilities - Energy Efficiency Construction } \\
\text { Incentive; Riverside Public Utilities - Residential Photovoltaic } \\
\text { Incentive Program; Roseville Electric - PV Buy Down Program; } \\
\text { SMUD Commercial/Industrial PV Rebate; SMUD - PV Pioneers } \\
\text { Residential Buy-Down; SMUD - Solar Water Heater Program } \\
\text { Rebate; Ukiah Utilities - PV Buy-Down Program } \\
\text { Marin County - Solar Rebate Program; San Diego - Residential } \\
\text { Solar Electric Incentive for Homes Destroyed in Wildfires } \\
\text { Santa Monica - Green Building Grant Program; SMUD - Solar } \\
\text { Water Heater Loan Program; } \\
\text { Supplemental Energy Payments (SEPs) }\end{array}$ \\
\hline $\mathrm{CO}$ & & $\begin{array}{l}\text { Utility PV Rebate; Holy Cross Energy WE CARE Rebates } \\
\text { Aspen Solar Pioneer Program - Solar Hot Water Rebate; Gunnison } \\
\text { County Electric - Renewable Energy Resource Loan; Aspen Solar } \\
\text { Pioneer Program - Zero-Interest Loan } \\
\text { Colorado - Aspen - Grid-Tied Micro Hydro Production Incentive }\end{array}$ \\
\hline CT & Local Option for Property Tax & $\begin{array}{l}\text { Residential Solar PV Rebate Program; Connecticut - Commercial, } \\
\text { Industrial, Institutional PV Grant Program; Connecticut - New } \\
\text { Energy Technology Program; Energy Conservation Loan; } \\
\text { Operational Demonstration Program; Renewable Energy Projects in } \\
\text { Pre-Development Program }\end{array}$ \\
\hline $\mathrm{DE}$ & & $\begin{array}{l}\text { Green Energy Program Rebates; Research and Development } \\
\text { Grants; Technology and Demonstration Grants }\end{array}$ \\
\hline $\mathrm{DC}$ & & District of Columbia Renewable Demonstration Project \\
\hline FL & $\begin{array}{l}\text { Solar Energy Equipment } \\
\text { Exemption }\end{array}$ & $\begin{array}{l}\text { Florida - Gainesville Regional Utilities - Solar Rebate Program; } \\
\text { Florida - JEA - Solar Incentive Program }\end{array}$ \\
\hline GA & & \\
\hline
\end{tabular}




\begin{tabular}{|c|c|c|}
\hline State & Tax Incentives & Grants, Loans, Rebates and Other Incentives \\
\hline $\mathrm{HI}$ & $\begin{array}{l}\text { Residential Solar and Wind } \\
\text { Energy Credit; Corporate Solar } \\
\text { and Wind Energy Credit }\end{array}$ & $\begin{array}{l}\text { HECO, MECO, HELCO - Energy \$olutions Solar Water Heater } \\
\text { Rebate; Kaua'i Island Utility Cooperative - Commercial Solar Water } \\
\text { Heating Program; Oahu - Energy \$olutions Honolulu Solar Roofs } \\
\text { Initiative Loan Program; Kauai County - Solar Water Heating Loan } \\
\text { Program; Maui County - Maui Solar Roofs Initiative Loan Program } \\
\text { for Solar Water Heating }\end{array}$ \\
\hline ID & $\begin{array}{l}\text { Solar, Wind, and Geothermal } \\
\text { Deduction (Personal) }\end{array}$ & $\begin{array}{l}\text { Renewable Energy Equipment Sales Tax Refund; BEF - Renewable } \\
\text { Energy Grant; BEF - Solar 4R Schools; Low-Interest Loans for } \\
\text { Renewable Energy Resource Program }\end{array}$ \\
\hline IL & $\begin{array}{l}\text { Special Assessment for } \\
\text { Renewable Energy Systems }\end{array}$ & Illinois Clean Energy Community Foundation Grants \\
\hline IN & $\begin{array}{l}\text { Renewable Energy Systems } \\
\text { Exemption }\end{array}$ & $\begin{array}{l}\text { Alternative Power \& Energy Grant Program; Distributed Generation } \\
\text { Grant Program (DGGP); Energy Education and Demonstration } \\
\text { Grant Program; Energy Efficiency and Renewable Energy (EERE) } \\
\text { Set-Aside }\end{array}$ \\
\hline IA & $\begin{array}{l}\text { Renewable Energy Production } \\
\text { Tax Credit (Personal); Renewable } \\
\text { Energy Production Tax Credit } \\
\text { (Corporate); Wind Energy } \\
\text { Equipment Exemption; Local } \\
\text { Option Special Assessment of } \\
\text { Wind Energy Devices; Methane } \\
\text { Gas Conversion Property Tax } \\
\text { Exemption; Property Tax } \\
\text { Exemption for Renewable Energy } \\
\text { Systems }\end{array}$ & $\begin{array}{l}\text { Grants for Energy Efficiency and Renewable Energy Research; } \\
\text { Alternate Energy Revolving Loan Program; lowa Building Energy } \\
\text { Management Program (lowa Energy Bank) }\end{array}$ \\
\hline KS & $\begin{array}{l}\text { Renewable Energy Property Tax } \\
\text { Exemption }\end{array}$ & State Energy Program Grants \\
\hline$\overline{\mathrm{KY}}$ & & Solar Water Heater Loan Program \\
\hline LA & Solar Energy System Exemption & \\
\hline ME & & $\begin{array}{l}\text { Solar Rebate Program; Renewable Resources Matching Fund } \\
\text { Program }\end{array}$ \\
\hline MD & $\begin{array}{l}\text { Personal Income Tax Credit for } \\
\text { Green Buildings; Corporate } \\
\text { Income Tax Credit for Green } \\
\text { Buildings; Wood Heating Fuel } \\
\text { Exemption; Local Option - } \\
\text { Corporate Property Tax Credit; } \\
\text { Special Property Assessment }\end{array}$ & $\begin{array}{l}\text { Solar Energy Grant Program; Community Energy Loan Program; } \\
\text { State Agency Loan Program; Montgomery County - Clean Energy } \\
\text { Rewards Program }\end{array}$ \\
\hline MA & $\begin{array}{l}\text { Alternative Energy and Energy } \\
\text { Conservation Patent Exemption } \\
\text { (Personal); Renewable Energy } \\
\text { State Income Tax Credit; } \\
\text { Alternative Energy and Energy } \\
\text { Conservation Patent Exemption } \\
\text { (Corporate); Solar and Wind } \\
\text { Energy System Deduction; Solar } \\
\text { and Wind Power Systems Excise } \\
\text { Tax Exemption; Renewable } \\
\text { Energy Equipment Sales Tax } \\
\text { Exemption; Local Property Tax } \\
\text { Exemption }\end{array}$ & $\begin{array}{l}\text { Commercial, Industrial, \& Institutional Initiative Grants; Small } \\
\text { Renewables Initiative Rebate; Matching Grants for Communities }\end{array}$ \\
\hline $\mathrm{Ml}$ & $\begin{array}{l}\text { Alternative - Energy Personal } \\
\text { Property Tax Exemption; }\end{array}$ & $\begin{array}{l}\text { Community Energy Project Grants; Energy Efficiency Grants; Large- } \\
\text { Scale PV Demonstration Project Grants; Michigan Biomass Energy } \\
\text { Program Grants; Solar Domestic Hot Water System Rebate } \\
\text { Program; Small Business P2 Loan Program }\end{array}$ \\
\hline $\mathrm{MN}$ & $\begin{array}{l}\text { Solar-Electric (PV) Sales Tax } \\
\text { Exemption; Wind Sales Tax } \\
\text { Exemption; Wind and Solar- }\end{array}$ & $\begin{array}{l}\text { State of Minnesota Solar-Electric (PV) Rebate Program; Great River } \\
\text { Energy - Solar-Electric (PV) Rebate Program; Minnesota Power } \\
\text { Solar-Electric (PV) Rebate Program; Renewable Development Fund }\end{array}$ \\
\hline
\end{tabular}




\begin{tabular}{|c|c|c|}
\hline State & Tax Incentives & Grants, Loans, Rebates and Other Incentives \\
\hline & Electric (PV) Systems Exemption & $\begin{array}{l}\text { Grants; Agricultural Improvement Loan Program for Wind Energy; } \\
\text { Energy Investment Loan Program; Value-Added Stock Loan } \\
\text { Participation Program } \\
\text { Renewable Energy Production Incentives }\end{array}$ \\
\hline MS & & Energy Investment Loan Program \\
\hline $\mathrm{MO}$ & Wood Energy Production Credit & Missouri Schools Going Solar; Energy Loan Program \\
\hline MT & $\begin{array}{l}\text { Residential Alternative Energy } \\
\text { System Tax Credit; Residential } \\
\text { Geothermal Systems Credit; } \\
\text { Alternative Energy Investment } \\
\text { Corporate Tax Credit; Corporate } \\
\text { Property Tax Reduction for } \\
\text { New/Expanded Generating } \\
\text { Facilities; Generation Facility } \\
\text { Corporate Tax Exemption; } \\
\text { Renewable Energy Systems } \\
\text { Exemption }\end{array}$ & $\begin{array}{l}\text { NorthWestern Energy - USB Renewable Energy Fund; BEF - } \\
\text { Renewable Energy Grant; BEF - Solar 4R Schools; Alternative } \\
\text { Energy Revolving Loan Program }\end{array}$ \\
\hline $\mathrm{NE}$ & & Dollar and Energy Savings Loans \\
\hline NV & $\begin{array}{l}\text { Renewable Energy/Solar Sales } \\
\text { Tax Exemption; Property Tax } \\
\text { Abatement for Green Buildings; } \\
\text { Renewable Energy Producers } \\
\text { Property Tax Abatement; } \\
\text { Renewable Energy Systems } \\
\text { Property Tax Exemption }\end{array}$ & Solar Generations PV Rebate Program \\
\hline $\mathrm{NH}$ & $\begin{array}{l}\text { Local Option Property Tax } \\
\text { Exemption for Renewable Energy }\end{array}$ & \\
\hline $\mathrm{NJ}$ & $\begin{array}{l}\text { Solar and Wind Energy Systems } \\
\text { Exemption }\end{array}$ & $\begin{array}{l}\text { New Jersey Clean Energy Rebate Program; Renewable Energy } \\
\text { Advanced Power Program; Renewable Energy Economic } \\
\text { Development Program (REED); Renewable Energy Business } \\
\text { Venture Assistance Program (REBVAP); Clean Energy Financing } \\
\text { for Local Schools and Governments }\end{array}$ \\
\hline NM & $\begin{array}{l}\text { Renewable Energy Production } \\
\text { Tax Credit; Biomass Equipment } \\
\text { and Materials Deduction; }\end{array}$ & Clean Energy Grants Program; Schools with Sol \\
\hline NY & $\begin{array}{l}\text { Solar and Fuel Cell Tax Credit; } \\
\text { Solar Cells Tax Exemption; Solar, } \\
\text { Wind and Biomass Energy } \\
\text { Systems Exemption }\end{array}$ & $\begin{array}{l}\text { Energy \$mart New Construction Program; PV Incentive Program; } \\
\text { Wind Incentive Program; LIPA - Solar Pioneer Program; } \\
\text { Renewables R\&D Grant Program; Energy \$mart Loan Fund }\end{array}$ \\
\hline NC & $\begin{array}{l}\text { Renewable Energy Tax Credit - } \\
\text { Personal; Renewable Energy Tax } \\
\text { Credit - Corporate; Active Solar } \\
\text { Heating and Cooling Systems } \\
\text { Exemption }\end{array}$ & Energy Improvement Loan Program (EILP) \\
\hline ND & $\begin{array}{l}\text { Geothermal, Solar and Wind } \\
\text { Personal Credit; Geothermal, } \\
\text { Solar, and Wind Corporate Credit; } \\
\text { Hydrogen and Large Wind Sales } \\
\text { Tax Exemption; Geothermal, } \\
\text { Solar, and Wind Property } \\
\text { Exemption; Large Wind Property } \\
\text { Tax Reduction }\end{array}$ & \\
\hline $\mathrm{OH}$ & $\begin{array}{l}\text { Conversion Facilities Corporate } \\
\text { Tax Exemption; Conversion } \\
\text { Facilities Sales Tax Exemption; } \\
\text { Conversion Facilities Property Tax } \\
\text { Exemption }\end{array}$ & Residential Renewable Energy Grants; Renewable Energy Loans \\
\hline
\end{tabular}




\begin{tabular}{|c|c|c|}
\hline State & Tax Incentives & Grants, Loans, Rebates and Other Incentives \\
\hline OK & $\begin{array}{l}\text { Zero-Emission Facilities } \\
\text { Production Tax Credit }\end{array}$ & \\
\hline OR & $\begin{array}{l}\text { Residential Energy Tax Credit; } \\
\text { Business Energy Tax Credit; } \\
\text { Renewable Energy Systems } \\
\text { Exemption }\end{array}$ & $\begin{array}{l}\text { Energy Trust Solar Electric Buy-Down Program; Energy Trust Solar } \\
\text { Water Heating Buy-Down Program; Ashland - Solar Electric } \\
\text { Program; Ashland Electric Utility - The Bright Way to Heat Water } \\
\text { Rebate; EPUD - Solar Water Heater Program Rebate; EWEB - } \\
\text { Energy Management Services Rebate; EWEB - The Bright Way To } \\
\text { Heat Water Rebate; OTEC - Photovoltaic Rebate Program; Energy } \\
\text { Trust Open Solicitation Program; BEF - Renewable Energy Grant; } \\
\text { BEF - Solar 4R Schools; Small Scale Energy Loan Program } \\
\text { (SELP); Ashland Electric Utility - The Bright Way to Heat Water } \\
\text { Loan; EPUD - Solar Water Heater Program Loan; EWEB - Energy } \\
\text { Management Services Loan; EWEB - The Bright Way To Heat } \\
\text { Water Loan }\end{array}$ \\
\hline$\overline{\mathrm{PA}}$ & & $\begin{array}{l}\text { Sustainable Development Fund Solar PV Grant Program (PECO } \\
\text { Territory); Pennsylvania Energy Harvest Grant Program; } \\
\text { Metropolitan Edison Company SEF Grants (FirstEnergy Territory); } \\
\text { Penelec SEF of the Community Foundation for the Alleghenies } \\
\text { Grant Program (FirstEnergy Territory); SEF of Central Eastern } \\
\text { Pennsylvania Grant Program (PP\&L Territory); Sustainable } \\
\text { Development Fund Grant Program (PECO Territory); West Penn } \\
\text { Power SEF Grant Program; Metropolitan Edison Company SEF } \\
\text { Loans (FirstEnergy Territory); Penelec SEF of the Community } \\
\text { Foundation for the Alleghenies Loan Program (FirstEnergy } \\
\text { Territory); SEF of Central Eastern Pennsylvania Loan Program } \\
\text { (PP\&L Territory); Sustainable Development Fund Commercial } \\
\text { Financing Program (PECO Territory); West Penn Power SEF } \\
\text { Commercial Loan Program }\end{array}$ \\
\hline $\mathrm{RI}$ & $\begin{array}{l}\text { Residential Renewable Energy } \\
\text { Tax Credit; Renewable Energy } \\
\text { Sales Tax Exemption; Solar } \\
\text { Property Tax Exemption }\end{array}$ & $\begin{array}{l}\text { PV \& Wind Rebate Program; Small Customer Incentive Program for } \\
\text { Green Power Marketers; RFP for Purchase/Sale of Renewable } \\
\text { Electricity to Large Customers } \\
\text { Renewable Generation Supply Incentive }\end{array}$ \\
\hline SC & & Residential Solar Initiative for EarthCraft Homes Rebate \\
\hline SD & $\begin{array}{l}\text { Renewable Energy Systems } \\
\text { Exemption; Wind Energy Property } \\
\text { Tax Exemption }\end{array}$ & \\
\hline TN & Wind Energy Systems Exemption & Small Business Energy Loan Program \\
\hline TX & $\begin{array}{l}\text { Solar Energy Device Franchise } \\
\text { Tax Deduction; Renewable } \\
\text { Energy Systems Property Tax } \\
\text { Exemption }\end{array}$ & $\begin{array}{l}\text { Austin Energy - Home Energy Air Conditioning and Appliance } \\
\text { Rebates; Austin Energy - Solar Rebate Program }\end{array}$ \\
\hline UT & $\begin{array}{l}\text { Renewable Energy Systems Tax } \\
\text { Credit - Personal; Renewable } \\
\text { Energy Systems Tax Credit - } \\
\text { Corporate; Renewable Energy } \\
\text { Sales Tax Exemption } \\
\end{array}$ & \\
\hline VT & Sales Tax Exemption & Solar \& Small Wind Incentive Program; CVPS Biomass Grants \\
\hline VA & $\begin{array}{l}\text { Local Option Property Tax } \\
\text { Exemption for Solar }\end{array}$ & Virginia Small Wind Incentives Program (VSWIP) \\
\hline WA & Sales and Use Tax Exemption & $\begin{array}{l}\text { Clallam County PUD - Solar Rebate Program; Clark Public Utilities } \\
\text { - Solar Water Heater Rebate Program; Grays Harbor PUD - Solar } \\
\text { Water Heating Rebate; Klickitat PUD - Solar Rebate; Orcas Power } \\
\text { \& Light - Photovoltaic Rebate; Puget Sound Energy - Solar PV } \\
\text { System Rebate; Franklin PUD - Photovoltaic and Solar Water } \\
\text { Heating Rebate; }\end{array}$ \\
\hline WV & $\begin{array}{l}\text { Tax Exemption for Wind Energy } \\
\text { Generation; Special Assessment } \\
\text { for Wind Energy Systems }\end{array}$ & \\
\hline
\end{tabular}




\begin{tabular}{|l|l|l|}
\hline State & \multicolumn{1}{|c|}{ Tax Incentives } & \multicolumn{1}{c|}{ Grants, Loans, Rebates and Other Incentives } \\
\hline WI & $\begin{array}{l}\text { Solar and Wind Energy } \\
\text { Equipment Exemption }\end{array}$ & $\begin{array}{l}\text { Focus on Energy - Cash-Back Reward; Wisconsin Public Power, } \\
\text { Inc. - Residential Renewable Energy Rebate; Focus on Energy - } \\
\text { Grant Programs; Focus on Energy - Zero-Interest Loans; Wisconsin } \\
\text { Public Power, Inc. - Residential Renewable Energy Loan }\end{array}$ \\
\hline WY & $\begin{array}{l}\text { Renewable Energy Sales Tax } \\
\text { Exemption }\end{array}$ & Photovoltaic Incentive Program \\
\hline
\end{tabular}

Source: North Carolina Solar Center, Database of State Incentives for Renewable Energy,

http://www.dsireusa.org/summarytables/financial.cfm?\&CurrentPagelD=7, November 2005. 


\section{Table 4.1 - Projections of Renewable Electricity Net Capacity}

(Gigawatts)

\begin{tabular}{|c|c|c|c|c|c|c|c|}
\hline \multirow[b]{2}{*}{ Renewable Energy } & \multirow[t]{2}{*}{ Data Sources } & \multicolumn{6}{|c|}{ Projections } \\
\hline & & $\underline{2006}$ & $\underline{2010}$ & $\underline{2015}$ & $\underline{2020}$ & $\underline{2025}$ & $\underline{2030}$ \\
\hline \multirow[t]{3}{*}{ Geothermal } & AEO2006 - Reference Case & 2.23 & 2.56 & 3.19 & 4.61 & 6.02 & 6.64 \\
\hline & AEO2006 - High Renewables & & 2.80 & & 6.19 & & 9.14 \\
\hline & EERE GPRA FY07 & & 2.21 & 2.61 & 3.53 & 4.88 & \\
\hline \multirow[t]{3}{*}{ Wind } & AEO2006 - Reference Case & 11.56 & 16.27 & 17.71 & 18.81 & 19.80 & 20.10 \\
\hline & AEO2006 - High Renewables & & 16.27 & & 18.87 & & 22.63 \\
\hline & EERE GPRA FY07 & & 8.91 & 18.98 & 77.66 & 135.85 & \\
\hline \multirow[t]{3}{*}{ Solar ${ }^{1}$} & AEO2006 - Reference Case & 0.67 & 1.17 & 1.31 & 1.47 & 1.71 & 2.62 \\
\hline & AEO2006 - High Renewables & & 1.17 & & 1.47 & & 2.87 \\
\hline & EERE GPRA FY07 & & 1.97 & 6.27 & 31.16 & 68.86 & \\
\hline \multirow[t]{3}{*}{ Hydroelectric } & AEO2006 - Reference Case & 78.31 & 78.32 & 78.37 & 78.53 & 78.53 & 78.53 \\
\hline & AEO2006 - High Renewables & & 78.33 & & 78.41 & & 78.76 \\
\hline & EERE GPRA FY07 & & 79.21 & 79.21 & 79.21 & 79.21 & \\
\hline \multirow[t]{3}{*}{$\begin{array}{l}\text { Biomass/Wood } \\
\text { (excludes cogen) }\end{array}$} & AEO2006 - Reference Case & 2.09 & 2.15 & 2.15 & 2.46 & 3.45 & 4.63 \\
\hline & AEO2006 - High Renewables & & 2.20 & & 3.96 & & 10.55 \\
\hline & EERE GPRA FY07 & & 1.83 & 2.01 & 2.62 & 4.57 & \\
\hline \multirow[t]{3}{*}{ MSW and LFG } & AEO2006 - Reference Case & 3.55 & 3.78 & 3.92 & 4.02 & 4.11 & 4.14 \\
\hline & AEO2006 - High Renewables & & 3.79 & & 4.03 & & 4.14 \\
\hline & EERE GPRA FY07 ${ }^{2}$ & & 3.83 & 3.84 & 3.92 & 3.93 & \\
\hline \multirow[t]{3}{*}{ Total Renewable Energy } & AEO2006 - Reference Case & 102.92 & 109.26 & 112.12 & 115.93 & 120.21 & 123.95 \\
\hline & AEO2006 - High Renewables & & 109.82 & & 119.81 & & 137.09 \\
\hline & EERE GPRA FY07 ${ }^{3}$ & & 98.54 & 115.53 & 196.25 & 225.38 & \\
\hline
\end{tabular}

Sources: EIA Annual Energy Outlook 2006, DOE/EIA-0383 (2006) (Washington, D.C., February 2006), Tables A16 and D7. Total Renewable Capacity GPRA projections provided by OnLocation, February 2006.

Notes: OnLocation GPRA07 benefits estimates do not estimate any programmatic influence on biomass power, because the Biomass Program has been redirected away from biomass power to integrated biorefinery technologies. "Total" represents portfolio case values, while individual program values represent each program case. The portfolio case accounts for program interactions and micro-price feedback effects. The GPRA FY07 modeling effort uses the NEMS model, which uses the EIA AEO 2005 as the baseline for its analysis.

${ }^{1}$ Solar-thermal and photovoltaic energy.

${ }^{2}$ EERE does not have an R\&D program for biomass, LFG/MSW, so they are not included in GPRA projections.

${ }^{3}$ Biomass, MSW, and LFG are not included in the portfolio value. The portfolio values do not equal the summed values of the individual programs, as the portfolio analysis accounts for program interactions and micro-price feedback effects. Total includes biomass combined heat and power and on-site electricity-only plants for industrial and commercial sectors not detailed above. 


\section{Table 4.2 - Projections of Renewable Electricity Net Generation}

(Billion Kilowatthours)

\author{
Data Sources \\ Data Sources
}

\section{Renewable Energy}

Geothermal

Geothermal

Wind

Solar $^{1}$

Hydroelectric

Biomass/Wood (without cogeneration)

\author{
AEO2006 - Reference Case \\ AEO2006 - High Renewables \\ EERE GPRA FY07
}

AEO2006 - Reference Case

AEO2006 - High Renewables

EERE GPRA FY07

AEO2006 - Reference Case

AEO2006 - High Renewables

EERE GPRA FY07

AEO2006 - Reference Case

AEO2006 - High Renewables

EERE GPRA FY07
MSW and LFG
AEO2006 - High Renewables
EERE GPRA FY07
AEO2006 - Reference Case
AEO2006 - High Renewables
EERE GPRA FY0 $7^{2}$
Total Renewable Energy

AEO2006 - Reference Case

\begin{tabular}{rrrrrr}
\multicolumn{7}{c}{ Projections } \\
$\underline{\mathbf{2 0 0 6}}$ & $\underline{\mathbf{2 0 1 0}}$ & $\underline{\mathbf{2 0 1 5}}$ & $\underline{\mathbf{2 0 2 0}}$ & $\underline{\mathbf{2 0 2 5}}$ & $\underline{\mathbf{2 0 3 0}}$ \\
14.91 & 17.51 & 22.84 & 34.01 & 46.74 & 52.70 \\
& 19.16 & & 47.91 & & 73.01 \\
& 12.30 & 15.60 & 23.50 & 35.00 & \\
& & & & & \\
35.25 & 50.87 & 55.98 & 59.82 & 63.48 & 64.51 \\
& 50.87 & & 59.97 & & 73.90 \\
& 25.80 & 64.60 & 309.40 & 558.60 & \\
& & & & & \\
1.19 & 2.35 & 2.69 & 3.10 & 3.68 & 5.71 \\
& 2.36 & & 3.10 & & 6.25 \\
& 3.90 & 12.80 & 63.10 & 151.10 &
\end{tabular}

$293.13 \quad 301.40$

301.82

302.87

303.06

303.27

301.40

302.15

304.46

303.60

303.70

304.00

304.30

18.87

44.67
45.45

44.80

48.59

51.30

57.83

59.94

95.96

27.20

29.60

32.10

39.30

25.29

27.13
27.13

28.20

29.06

29.75

30.03

27.70

27.80

29.08

30.04

417.45

475.75

490.86

515.15

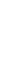

544.91

539.06

559.14

479.65

$400.70 \quad 454.70 \quad 742.60 \quad 927.90$
$400.70 \quad 454.70 \quad 742.60 \quad 927.90$

Sources: EIA Annual Energy Outlook 2006, DOE/EIA-0383 (2006) (Washington, D.C., February 2006), Tables A16 and D7. Renewable generation GPRA projections provided by OnLocation, February 2006.

Notes: OnLocation GPRA07 benefits estimates do not estimate any programmatic influence on biomass power, because the Biomass Program has been redirected away from biomass power to integrated biorefinery technologies. "Total" represents portfolio case values, while individual program values represent each program case. The portfolio case accounts for program interactions and micro-price feedback effects. The GPRA FY07 modeling effort uses the NEMS model, which uses the EIA AEO 2005 as the baseline for its analysis.

${ }^{1}$ Solar-thermal and photovoltaic energy.

${ }^{2}$ EERE does not have an R\&D program for biomass, LFG/MSW, so they are not included in GPRA projections.

${ }^{3}$ Biomass, MSW, and LFG are not included in the portfolio value. The portfolio values do not equal the summed values of the individual programs, as the portfolio analysis accounts for program interactions and micro-price feedback effects. 


\section{Table 4.3 - Projections of Renewable Electricity Carbon Dioxide Emissions Savings}

(Million Metric Tons Carbon Equivalent per Year)

\section{Data Sources}

Renewable Energy

Geothermal

Wind

Solar $^{1}$

Hydroelectric

Biomass/Wood

MSW and LFG

$$
\begin{aligned}
& \text { AEO2006 - Reference Case } \\
& \text { AEO2006 - High Renewables } \\
& \text { EERE GPRA FY07 }
\end{aligned}
$$

AEO2006 - Reference Case

AEO2006 - High Renewables

EERE GPRA FY07

AEO2006 - Reference Case

AEO2006 - High Renewables

EERE GPRA FY07

AEO2006 - Reference Case

AEO2006 - High Renewables

EERE GPRA FY07

AEO2006 - Reference Case

AEO2006 - High Renewables

EERE GPRA FY07

AEO2006 - Reference Case

AEO2006 - High Renewables

EERE GPRA FY07 ${ }^{2}$

Total Renewable Energy

AEO2006 - Reference Case

AEO2006 - High Renewables

EERE GPRA FY $07^{3}$

\section{Projections}

$\underline{2006}$

2.87

3.48
3.81

4.22

5.59
7.87

7.17

6.88

2.44

2.88

3.86

5.37

6.79

10.10

10.34

9.83

9.74

8.42

9.85

9.65

$\begin{array}{llll}5.12 & 11.93 & 50.84 & 85.69\end{array}$

0.23

0.47
0.47

0.50

0.51

0.56

0.75

0.51

0.82

0.77

2.36

10.37

23.18

$56.43 \quad 59.86$

55.75

49.77

46.49

39.60

59.86

49.65

39.75

60.30

56.10

$49.96 \quad 46.68$

3.63

8.87

8.27

7.98

7.87

7.55

9.03

9.85

12.53

5.40

5.47

5.27

6.03

4.87

5.39

5.21

4.78

4.56

3.92

5.39

4.78

3.92

5.50

5.13

4.68

4.39

80.36

94.49

90.67

84.65

82.69

73.00

95.27

89.54

83.39

79.59

$83.99122 .03 \quad 142.34$
Heat Rate

Carbon Coefficient
$\mathrm{Btu} / \mathrm{kWh}$

MMTCE/Tbtu

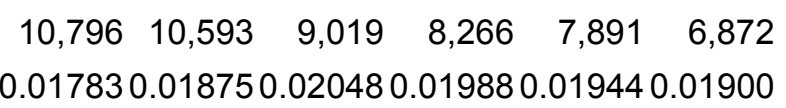

Sources: Generation data: EIA Annual Energy Outlook 2006, DOE/EIA-0383 (06) (Washington, D.C., February 2006), Tables A16 and F8. Renewable generation GPRA projections provided by OnLocation, February 2006. Heat Rate and Carbon Coefficienct data based on GPRA 2003 Data Call.

Carbon emission coefficients and heat rates for 2006-2025: U.S. Department of Energy, GPRA2003 Data Call, Appendix B, pages B-13 and B-16, (September 14, 2001). 2030 values are NREL estimates based on trend. 


\section{Notes:}

Carbon emissions savings based on calculation: (10^9 kWh) * (Btu/kWh) * (TBtu/10^12 Btu) * (MMTCE/TBtu)

${ }^{1}$ Solar-thermal and photovoltaic energy.

${ }^{2}$ EERE does not have an R\&D program for LFG/MSW, so they are not included in GPRA projections

${ }^{3}$ Biomass, MSW, and LFG are not included in the portfolio value. The portfolio values do not equal the summed values of the individual programs, as the portfolio analysis accounts for program interactions and micro-price feedback effects. 


\section{Table 5.1 - U.S. Total and Delivered Energy (Overview)}

(Quadrillion Btu per year)

\section{0

$\underline{2000}$ \\ $\underline{2001}$ \\ $\underline{2002}$}

2003

$\underline{2010}$

$\underline{2015}$

$\underline{2020}$

$\underline{2025}$

$\underline{2030}$

Total Consumption by Source 1

Petroleum ${ }^{2}$

34.20

Natural Gas

20.39

38.26

38.19

38.23

38.81

$\begin{array}{l:ll}39.83 & 43.14 & 45.69\end{array}$

Coal $^{3}$

15.39

19.74

23.91

23.62

23.07

22.98

24.04

26.67

48.14

50.57

$27.70 \quad 27.78$

53.58

\begin{tabular}{l|l}
23.66 & 25.09
\end{tabular}

25.66

27.65

30.89

27.66

23.54
7.86

8.03

8.14

7.96

Renewable $^{4}$

$5.49 \quad 6.13$

6.16

$\begin{array}{l:l}8.23 & 8.44\end{array}$

8.66

9.09

9.09

34.49

$\begin{array}{l:ll}6.12 & 7.08 & 7.43\end{array}$

8.00

8.61

9.09

Other $^{5}$

$0.07 \quad-0.03$

0.06

5.33

5.84
-0.01

6.08
-0.07

$\begin{array}{l:l}0.04 & 0.07\end{array}$

0.08

0.05

0.05

9.02

Total Primary

\subsection{9}

\section{Residential}

Commercial

15.85

$\begin{array}{lll}84.71 & 98.96 & 96.47\end{array}$

$97.87 \quad 98.31$

$\begin{array}{l:l}99.73 & 107.87\end{array}$

114.18

120.63

126.99

133.88

\section{Industrial}

Transportation

10.59

17.06

20.53

20.29

20.91

21.20

\begin{tabular}{l|l|l|}
21.18 & 22.99 & 24.07 \\
\hline
\end{tabular}

$\begin{array}{lll}25.17 & 25.88 & 26.64\end{array}$

$17.18 \quad 17.37$

$17.58 \quad 17.45$

\begin{tabular}{l|ll}
17.51 & 19.51 & 21.23
\end{tabular}

23.02

25.88
24.82

26.73

$\begin{array}{llll}34.70 & 32.53 & 32.53 & 32.56\end{array}$

33.25

34.46

35.60

36.95

38.77

40.58

\begin{tabular}{l|rrrrr}
27.79 & 30.90 & 33.29 & 35.50 & 37.52 & 39.93
\end{tabular}

Total Primary ${ }^{6}$

$\begin{array}{ll}78.70 & 22.42 \\ 78.29 & 84.71\end{array}$

$98.96 \quad 96.47$

$26.85 \quad 27.10$

99.73

107.87

114.18

120.63

$126.99 \quad 133.88$

$\begin{array}{lrrrr}\text { Residential } & 7.50 & 6.60 & 7.20 & 6.91 \\ \text { Commercial } & 4.10 & 3.85 & 4.22 & 4.04 \\ \text { Industrial } & 22.67 & 21.21 & 22.80 & 21.80 \\ \text { Transportation }^{\text {Total Delivered }} & 19.66 & 22.37 & 26.49 & 26.22 \\ & 53.93 & 54.03 & 60.72 & 58.96\end{array}$

$\begin{array}{rr}6.89 & 7.19 \\ 4.10 & 4.26 \\ 21.77 & 21.48 \\ 26.79 & 27.03 \\ 59.54 & 59.95\end{array}$

$\begin{array}{r:rr}7.02 & 12.25 & 12.81 \\ 4.07 & 9.00 & 9.85 \\ 22.08 & 26.67 & 27.72 \\ 27.71 & 30.70 & 33.09 \\ 60.88 & 78.62 & 83.46\end{array}$

13.31

$13.64 \quad 14.04$

$\begin{array}{lll}10.66 & 11.50 \quad 12.44\end{array}$

$28.91 \quad 30.58 \quad 32.19$

$35.30 \quad 37.31 \quad 39.72$

Total Delivered ${ }^{6}$

$53.93-54.03$

Sources: EIA, Annual Energy Outlook 2006, DOE/EIA-0383(2006) (Washington, D.C., February 2006), Tables A1 and A2; EIA, Annual Energy Review 2004, DOE/EIA-0384(2004) (Washington, D.C., August 2005), Tables 2.1a-f.

\section{Notes:}

${ }^{1}$ For historical figures, these values include the electric-power sector's consumption.

${ }^{2}$ Includes natural gas plant liquids, crude oil consumed as a fuel, and nonpetroleum-based liquids for blending, such as ethanol.

${ }^{3}$ Includes coal in all sectors, as well as net imports of coal coke in the industrial sector.

${ }^{4}$ Includes grid-connected electricity from conventional hydroelectric; wood and wood waste; landfill gas; municipal solid waste; other biomass; wind; photovoltaic and solar-thermal sources; nonelectric energy from renewable sources, such as active and passive solar systems, and wood for residential heating; and both the ethanol and gasoline components of E85 (which, due to seasonal adjustments in mix, is E74, on average), but not lower percentage blends of ethanol (e.g. E10). Excludes electricity imports using renewable sources and nonmarketed renewable energy. 
${ }^{5}$ For historical figures, this value includes hydroelectric pumped storage and electricity net imports - except in 2004, where it only shows electricity net imports (AER 2004 no longer includes hydroelectric pumped storage). For forecasted figures, this value includes net electricity imports, methanol, and liquid hydrogen.

${ }^{6}$ For historical figures, this value does not include the electric-power sector's consumption.

7 All 2004 figures are preliminary. 
Table 5.2 - Electricity Flow Diagram (Quadrillion Btu)

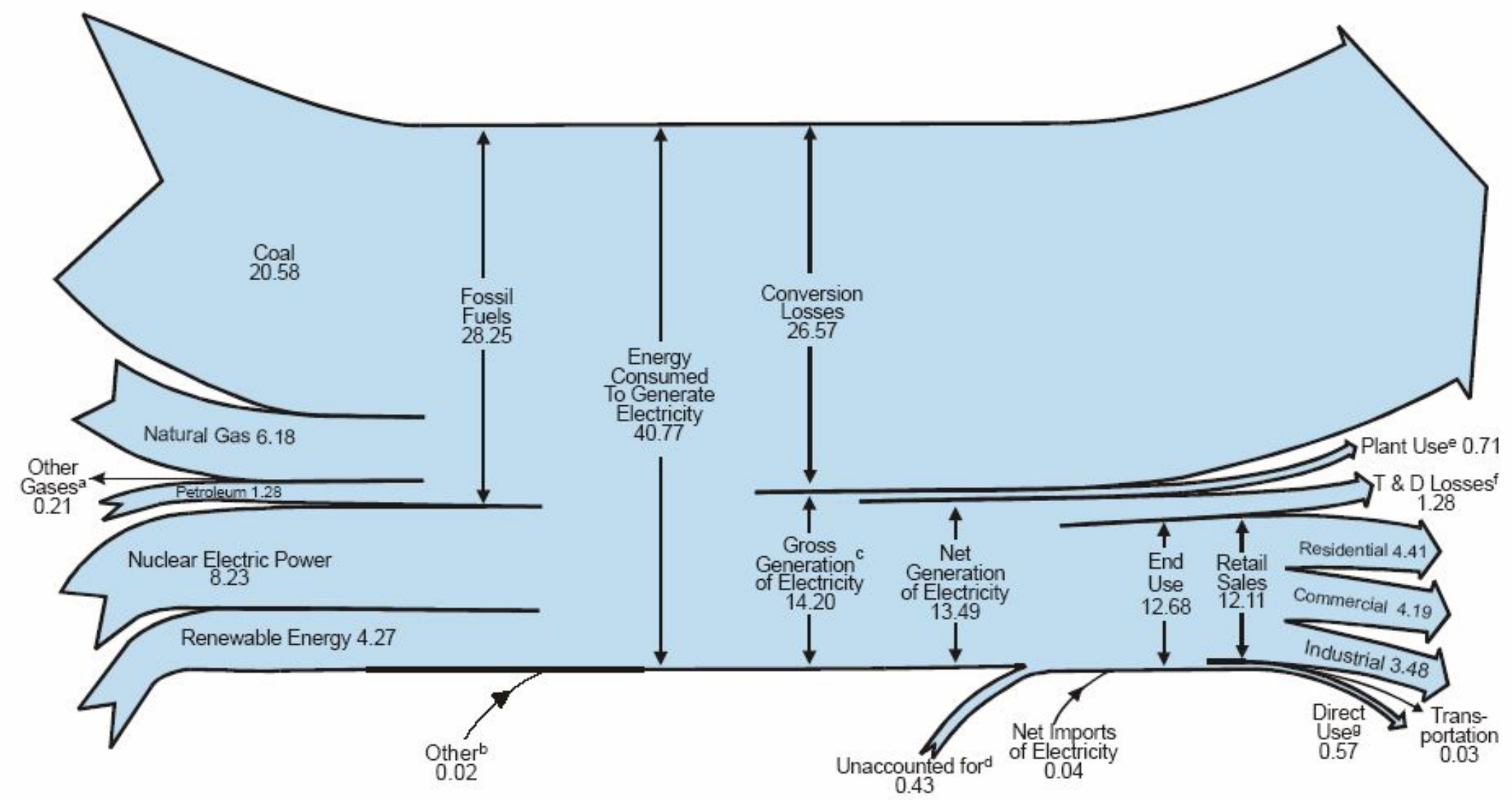

Source: EIA, Annual Energy Review 2004, DOE/EIA-0384(2004) (Washington, D.C., August 2005), Diagram 5.

Notes:

a Blast furnace gas, propane gas, and other manufactured and waste gases derived from fossil fuels.

b Batteries, chemicals, hydrogen, pitch, purchased steam, sulfur and miscellaneous technologies.

e Electric energy used in the operation of power plants, estimated as $5 \%$ of gross generation.

f Transmission and distribution losses (electricity losses that occur between the point of generation and delivery to the customer) are estimated as $9 \%$ of gross generation. 
$g$ Use of electricity that is 1) self-generated, 2) produced by either the same entity that consumes the power or an affiliate, and 3) used in direct support of a service or industrial process located within the same facility or group of facilities that house the generating equipment. Direct use is exclusive of station use.

d Data collection frame differences and sampling error.

Totals may not equal sum of components, due to independent rounding. 
Table 5.3 - Electricity Overview

(Billion Kilowatthours, unless otherwise noted)

1980

1990

$\underline{2003}$

$2004^{7}$

$\underline{2010}$

$\underline{2015}$

$\underline{2020}$

$\underline{2025}$

$\underline{2030}$

Electric-Power Sector

Generation 1

$\begin{array}{rrr}2,286 & 2,901 & 3,638 \\ 3 & 137 & 164 \\ 2,290 & 3,038 & 3,802\end{array}$

$3,580 \quad 3,698$

3,721

3,794

4,196

4,501

4,827

5,121

5,497

End-Use Sector Generation

2,290

3,737

3,858

3,883

3,953

4,388

4,727

5,108

5,491

5,926

Capability (gigawatts)

Electric-Power Sector ${ }^{2}$

End-Use Sector ${ }^{3}$

579

Total Capability

710
NA $\quad 24$

782

819
29

876

919

$579 \quad 734$

812

848

905

949

\begin{tabular}{r|r}
938 & 988 \\
30 & 32 \\
968 & 1,021
\end{tabular}

965
37

$1,098 \quad 1,186$

Imports from Canada/Mexico

Exports to Canada/Mexico

$\begin{array}{rrrrr}25 & 18 & 49 & 39 & 36 \\ 4 & 16 & 15 & 16 & 14 \\ 216 & 203 & 243 & 226 & 253 \\ & & & & \\ 2,094 & 2,713 & 3,421 & 3,370 & 3,463 \\ \text { NA } & 125 & 171 & 163 & 166 \\ 2,094 & 2,838 & 3,592 & 3,533 & 3,629\end{array}$

30
24
233
3,488
168
3,656

$\begin{array}{r:r}34 & 42 \\ 22 & 21 \\ 248 & \mathrm{NA} \\ & \\ 3,551 & 3,978 \\ 166 & 177 \\ 3,717 & 4,155\end{array}$

$1,002 \quad 1,072$

1,154

64

1,250

Loss and Unaccounted for $^{4}$

Retail Sales $^{5}$

Total Use

2,094

$3,629 \quad 3,656$

$\begin{array}{l:l}3,717 & 4,155\end{array}$

$\begin{array}{rrrr}41 & 29 & 28 & 27 \\ 18 & 15 & 13 & 13 \\ \text { NA } & \text { NA } & \text { NA } & \text { NA } \\ & & & \\ 4,300 & 4,629 & 4,956 & 5,341 \\ 192 & 214 & 252 & 278 \\ 4,491 & 4,844 & 5,208 & 5,619\end{array}$

Sources: EIA, Annual Energy Outlook 2006, DOE/EIA-0383(2006) (Washington, D.C., February 2005), Tables A8, A9, and A10; EIA, Annual Energy Review 2004, DOE/EIA-0384(2004) (Washington, D.C., August 2005), Tables 8.1, 8.11a, 8.11b, and 8.11d.

Notes:

${ }^{1}$ Electricity-only and combined-heat-and-power (CHP) plants within the NAICS 22 category whose primary business is to sell electricity - or electricity and heat - to the public.Through 1988, data are for electric utilities only; beginning in 1989, data are for electric utilities and independent power producers.

2 Through 1988, data are for net summer capacity at electric utilities only. Beginning in 1989, data also include net summer capacity at independent power producers. All data after 1989 include electric-sector combined-heat-and-power (CHP) plants.

${ }^{3}$ Commercial and industrial combined-heat-and-power (CHP) and electricity-only plants; and small on-site generating systems in the residential, commercial, and industrial sectors used primarily for own-use generation, but which may also sell some power to the grid. Data begins in 1989.

${ }^{4}$ Electricity losses that occur between the point of generation and delivery to the customer, and data collection frame differences and nonsampling error.

${ }^{5}$ Electricity retail sales to ultimate customers reported by electric utilities and other energy-service providers.

${ }^{6}$ Commercial and industrial facility use of on-site net electricity generation; and electricity sales among adjacent or colocated facilities for which revenue information is not available.

$\mathrm{NA}=$ not available 


\section{Table 5.4 - Consumption of Fossil Fuels by Electric Generators}

\begin{tabular}{|c|c|c|c|c|c|c|c|c|c|c|c|c|}
\hline & $\underline{1980}$ & $\underline{1990}$ & $\underline{2000}$ & $\underline{2001}$ & $\underline{2002}$ & $\underline{2003}$ & $\underline{2004^{8}}$ & $\underline{2010}$ & $\underline{2015}$ & $\underline{2020}$ & $\underline{2025}$ & $\underline{2030}$ \\
\hline Coal (million short tons) ${ }^{1}$ & 569 & 781 & 983 & 962 & 975 & 1,003 & 1,013 & 1,140 & 1,161 & 1,235 & 1,354 & 1,502 \\
\hline Distillate Fuel Oil (million barrels) ${ }^{2}$ & 29 & 16 & 30 & 29 & 22 & 27 & 18 & 40 & 40 & 41 & 44 & 46 \\
\hline Residual Fuel Oil (million barrels) ${ }^{3}$ & 391 & 183 & 138 & 159 & 105 & 137 & 141 & 117 & 116 & 117 & 118 & 128 \\
\hline Petroleum Coke (million short tons) & 0.2 & 1.0 & 3.2 & 3.3 & 5.7 & 5.7 & 6.8 & NA & NA & NA & NA & NA \\
\hline Other Liquids (million barrels) ${ }^{4}$ & NA & 0.02 & 0.4 & 0.4 & 1.2 & 1.9 & 2.0 & NA & NA & NA & NA & NA \\
\hline Total Petroleum (million barrels) ${ }^{5}$ & 421 & 205 & 184 & 205 & 156 & 195 & 195 & 157 & 156 & 158 & 162 & 173 \\
\hline Natural Gas (billion cubic feet) & 3,682 & 3,147 & 5,014 & 5,142 & 5,408 & 4,909 & 5,217 & 5,509 & 7,142 & 7,459 & 7,052 & 6,381 \\
\hline \multicolumn{13}{|c|}{ Stocks of Coal and Petroleum (end of year) ${ }^{6}$} \\
\hline Coal (million short tons) & 183 & 156 & 102 & 138 & 142 & 122 & 107 & NA & NA & NA & NA & NA \\
\hline Petroleum (million barrels) ${ }^{7}$ & 136 & 84 & 41 & 57 & 52 & 53 & 50 & NA & NA & NA & NA & NA \\
\hline
\end{tabular}

Sources: EIA, Annual Energy Outlook 2006, DOE/EIA-0383(2006) (Washington, D.C., February 2006), Tables A2, A13, and A15; EIA, Annual Energy Review 2004, DOE/EIA-0384(2004) (Washington, D.C., August 2005), Table 8.5b and 8.8.

Notes:

Data is for electric-power sector consumption only. Data include fuel consumption to produce electricity by combined-heat-and-power plants. Through 1988, consumption data are for electric utilities only. Beginning in 1989, consumption data also include independent power producers.

${ }^{1}$ Anthracite, bituminous coal, subbituminous coal, lignite, waste coal, and synthetic coal.

${ }^{2}$ Light fuel oil (Nos. 1, 2, and 4). For 1949-1979, data are for gas turbine and internal combustion plant use of petroleum. For 19802000 , electric utility data also include small amounts of kerosene and jet fuel. Forecast values calculated from quadrillion Btu using conversion factor $5.825 \mathrm{MMBtu} / \mathrm{barrel}$.

${ }^{3}$ Heavy fuel oil (Nos. 5 and 6). For 1949-1979, data are for steam plant use of petroleum. For 1980-2000, electric utility data also include a small amount of fuel oil No. 4. Forecast values calculated from quadrillion Btu using conversion factor 6.287 MMBtu/barrel.

${ }^{4}$ Jet fuel, kerosene, other petroleum liquids, and waste oil.

${ }^{5}$ Petroleum coke is converted from short tons to barrels by multiplying by 5 .

In forecasted values, total petroleum is calculated sum.

${ }^{6}$ Through 1998, data are for electric utilities only. Beginning in 1999, data are for electric utilities and independent power producers.

${ }^{7}$ Includes distillate fuel oil, residual fuel oil, other liquids, and petroleum coke.

${ }^{8}$ All 2004 figures are preliminary

$\mathrm{NA}=$ not available 


\section{Table 5.5 - Electric-Power Sector Energy Consumption}

(Trillion Btu)

\begin{tabular}{|c|c|c|c|c|c|c|c|c|c|c|c|c|}
\hline & $\underline{1980}$ & 1990 & $\underline{2000}$ & $\underline{2001}$ & $\underline{2002}$ & $\underline{2003}$ & $\underline{2004^{5}}$ & $\underline{2010}$ & $\underline{2015}$ & $\underline{2020}$ & $\underline{2025}$ & $\underline{2030}$ \\
\hline Coal & 12,123 & 16,235 & 20,185 & 19,494 & 19,733 & 20,137 & 20,227 & 22,919 & 23,352 & 25,018 & 27,542 & 30,742 \\
\hline Natural Gas & 3,810 & 3,224 & 5,120 & 5,271 & 5,522 & 5,009 & 5,351 & 5,647 & 7,320 & 7,645 & 7,228 & 6,541 \\
\hline Petroleum & 2,634 & 1,281 & 1,145 & 1,270 & 955 & 1,199 & 1,196 & 971 & 960 & 972 & 998 & 1,068 \\
\hline Other Gas ${ }^{1}$ & NA & 6 & 19 & 9 & 25 & 30 & 30 & NA & NA & NA & NA & NA \\
\hline Total Fossil Fuels & 18,567 & 20,746 & 26,470 & 26,044 & 26,235 & 26,374 & 26,804 & 29,537 & 31,633 & 33,635 & 35,768 & 38,351 \\
\hline Nuclear Electric Power & 2,739 & 6,104 & 7,862 & 8,033 & 8,143 & 7,959 & 8,232 & 8,442 & 8,659 & 9,089 & 9,089 & 9,088 \\
\hline Hydroelectric Pumped Storage ${ }^{2}$ & --- & -36 & -57 & -90 & -88 & -88 & $--^{6}$ & NA & NA & NA & NA & NA \\
\hline Conventional Hydroelectric & 2,867 & 3,014 & 2,768 & 2,209 & 2,650 & 2,781 & 2,673 & 2,983 & 2,985 & 2,994 & 2,994 & 2,994 \\
\hline Wood & 3 & 106 & 126 & 116 & 141 & 156 & 158 & 518 & 522 & 566 & 584 & 633 \\
\hline Waste & 2 & 180 & 294 & 314 & 353 & 337 & 334 & 335 & 349 & 360 & 369 & 372 \\
\hline Geothermal & 110 & 326 & 296 & 289 & 305 & 303 & 302 & 393 & 567 & 918 & 1,333 & 1,538 \\
\hline Solar ${ }^{3}$ & NA & 4 & 5 & 6 & 6 & 5 & 6 & 10 & 13 & 15 & 18 & 21 \\
\hline Wind & NA & 29 & 57 & 70 & 105 & 115 & 143 & 524 & 577 & 616 & 654 & 665 \\
\hline Total Renewable Energy & 2,982 & 3,658 & 3,547 & 3,003 & 3,560 & 3,697 & 3,616 & 4,763 & 5,013 & 5,470 & 5,953 & 6,223 \\
\hline Electricity Imports & 71 & 8 & 115 & 75 & 78 & 22 & 39 & 74 & 79 & 49 & 50 & 48 \\
\hline Other ${ }^{4}$ & NA & 0.08 & 1.28 & 0.00 & 6.96 & 15.57 & 0.09 & NA & NA & NA & NA & NA \\
\hline Total Primary Consumption & 24,359 & 30,517 & 37,995 & 37,154 & 38,022 & 38,068 & 38,692 & 42,817 & 45,383 & 48,244 & 50,860 & 53,710 \\
\hline
\end{tabular}

\section{Notes:}

Data are for fuels consumed to produce electricity at both electricity-only and at combined-heat-and-power plants. Through 1988, data are for consumption at electric utilities only. Beginning in 1989, data also include consumption at independent power producers.

${ }^{1}$ Blast furnace gas, propane gas, and other manufactured and waste gases derived from fossil fuels.

${ }^{2}$ Pumped storage facility production minus energy used for pumping. 1980 data included in Conventional Hydroelectric.

${ }^{3}$ Solar-thermal and photovoltaic energy.

${ }^{4}$ Batteries, chemicals, hydrogen, pitch, purchased steam, sulfur, and miscellaneous technologies.

${ }^{5}$ All 2004 figures are preliminary 
${ }^{6}$ Starting with AER 2004 (August 2005), energy consumed by hydroelectric pumped storage plants is no longer included. According to EIA, the change was made because most of the electricity used to pump water into elevated storage reservoirs is generated by plants other than pumpedstorage plants; thus, the associated energy is already accounted for in other data columns in the tables (such as conventional hydroelectric power, coal, and natural gas). The data book has kept historical record of pumped storage hydroelectric pumped storage plants, because the information is useful to some analysts.

$\mathrm{NA}=$ not available 


\section{Table 5.6 - Fossil-Fuel Generation by Age of Generating Units}

(Megawatts)

$\begin{array}{lrrrrrrrrr} & \mathbf{1 9 8 0} & \underline{\mathbf{1 9 9 0}} & \underline{\mathbf{1 9 9 9}} & \underline{\mathbf{2 0 0 0}} & \underline{\mathbf{2 0 0 1}} & \underline{\mathbf{2 0 0 2}} & \underline{\mathbf{2 0 0 3}} & \underline{\mathbf{2 0 0 4}} & \underline{\mathbf{2 0 0 5}} \\ 0-5 & 91,001 & 39,870 & 34,466 & 54,274 & 90,877 & 155,534 & 204,504 & 218,854 & 233,119 \\ 6-10 & 136,236 & 54,270 & 42,215 & 44,042 & 42,164 & 37,735 & 33,121 & 33,234 & 33,976 \\ 11-20 & 145,618 & 224,879 & 102,855 & 92,854 & 87,057 & 82,977 & 83,140 & 81,085 & 81,465 \\ 21-30 & 99,223 & 143,868 & 226,166 & 221,690 & 210,982 & 196,464 & 175,461 & 156,694 & 156,078 \\ 31-40 & 21,042 & 93,450 & 128,613 & 141,055 & 155,292 & 172,139 & 188,274 & 205,136 & 204,382 \\ 41-50 & 4,023 & 14,701 & 80,859 & 86,582 & 91,321 & 94,204 & 95,560 & 93,156 & 89,731 \\ >50 & 4,232 & 2,566 & 8,291 & 11,634 & 15,259 & 18,161 & 24,487 & 33,967 & 31,676 \\ \text { Total: } & 501,376 & 573,603 & 623,465 & 652,129 & 692,952 & 757,214 & 804,546 & 822,128 & 830,427\end{array}$

Source: PowerDat, @ 2005, Platts, a division of the McGraw-Hill companies.

\section{Notes:}

Total MW does not equal fossil-fuel generation capacity cited in Table 6.1. Capacity reported in this table is nameplate capacity. 


\section{Table 5.7 - Nuclear Generation by Age of Generating Units}

(Megawatts)

$\begin{array}{lrrrrrrrrr} & \mathbf{1 9 8 0} & \underline{\mathbf{1 9 9 0}} & \underline{\mathbf{1 9 9 9}} & \underline{\mathbf{2 0 0 0}} & \underline{\mathbf{2 0 0 1}} & \underline{\mathbf{2 0 0 2}} & \underline{\mathbf{2 0 0 3}} & \underline{\mathbf{2 0 0 4}} & \underline{\mathbf{2 0 0 5}} \\ 0-5 & 16,289 & 30,408 & 1,270 & 1,270 & 0 & 0 & 0 & 0 & 0 \\ 6-10 & 33,989 & 25,628 & 4,810 & 1,215 & 2,485 & 2,485 & 1,270 & 1,270 & 1,270 \\ 11-20 & 6,413 & 48,929 & 54,432 & 56,036 & 51,537 & 49,189 & 47,200 & 40,278 & 31,435 \\ 21-30 & 309 & 6,073 & 44,558 & 44,597 & 46,859 & 43,105 & 41,420 & 39,315 & 40,533 \\ 31-40 & 0 & 0 & 2,143 & 4,095 & 6,332 & 12,435 & 17,324 & 26,351 & 32,940 \\ \text { Total } & 57,000 & 111,039 & 107,214 & 107,214 & 107,214 & 107,214 & 107,214 & 107,214 & 106,177\end{array}$

Source: PowerDat, @ 2005, Platts, a division of the McGraw-Hill companies.

Notes:

Total MW does not equal nuclear-generation capacity cited in Table 6.1.

Capacity reported in this table is nameplate capacity. 


\section{Table 5.8 - Operational Renewable Energy Generating Capacity}

(Megawatts)

\begin{tabular}{|c|c|c|c|c|c|c|}
\hline & $\underline{1980}$ & $\underline{1990}$ & $\underline{2000}$ & $\underline{2001}$ & $\underline{2002}$ & $\underline{\mathbf{2 0 0 3}}^{1}$ \\
\hline Agricultural Residues ${ }^{2}$ & 40 & 165 & 373 & 373 & 373 & 373 \\
\hline BioGas $^{3}$ & 18 & 361 & 933 & 999 & 1,030 & 1,053 \\
\hline Municipal Solid Waste ${ }^{4}$ & 263 & 2,172 & 2,970 & 2,970 & 2,970 & 3,000 \\
\hline Timber Residues ${ }^{5}$ & 3,576 & 6,305 & 7,447 & 7,458 & 7,497 & 7,497 \\
\hline Bioenergy Total $^{6}$ & 3,897 & 9,003 & 11,722 & 11,800 & 11,869 & 11,922 \\
\hline Geothermal & 802 & 2,540 & 2,779 & 2,779 & 2,779 & 2,779 \\
\hline Photovoltaic $^{7}$ & 0.025 & 4.170 & 27.645 & 38.452 & 59.703 & 67.710 \\
\hline Solar Thermal & 0 & 274 & 354 & 354 & 354 & 354 \\
\hline Hydro $^{8}$ & 80,491 & 90,955 & 94,324 & 94,335 & 94,335 & 94,356 \\
\hline Wind & 0.06 & 1,569 & 2,780 & 4,623 & 5,078 & 5,090 \\
\hline Total & 85,190 & 104,344 & 111,987 & 113,930 & 114,475 & 114,569 \\
\hline
\end{tabular}

Source: Renewable Electric Plant Information System (REPiS Database), Version 7, National Renewable Energy Laboratory, 2003, http://www.nrel.gov/analysis/repis/.

\section{Notes:}

Totals do not equal renewable generation capacity cited in Table 6.1.

${ }^{1} 2003$ data is preliminary; it is not verified at time of data book release

${ }^{2}$ Agricultural residues, cannery wastes, nut hulls, fruit pits, nut shells

${ }^{3}$ Biogas, alcohol (includes butahol, ethanol, and methanol), bagasse, hydrogen, landfill gas, livestock manure, wood gas (from wood gasifier)

${ }^{4}$ Municipal solid waste (includes industrial and medical), hazardous waste, scrap tires, wastewater sludge, refused-derived fuel

${ }^{5}$ Timber and logging residues (Includes tree bark, wood chips, saw dust, pulping liquor, peat, tree pitch, wood or wood waste)

${ }^{6}$ There are an additional $65.45 \mathrm{MW}$ of ag waste, $5.445 \mathrm{MW}$ of bio gas, and $483.31 \mathrm{MW}$ of wood residues that are

not accounted for here, because they have no specific online date.

${ }^{7}$ There are an additional 3.4 MW of photovoltaic capacity that are not accounted for here, because they have no specific online date.

${ }^{8}$ There are an additional $24 \mathrm{MW}$ of hydroelectric capacity that are not accounted for here, because they have no specific online date. 


\section{Table 5.9 - Number of Utilities by Class of Ownership and Nonutilities}

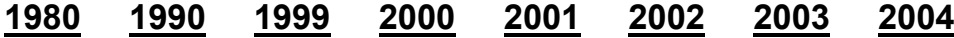

Investor-Owned Utilities

Federally Owned Utilities

Cooperatively Owned Utilities ${ }^{1}$

Other Publicly Owned Utilities

Total Number of Utilities

$\begin{array}{rrrrrrrr}240 & 266 & 238 & 240 & 232 & 230 & 223 & 220 \\ 41 & 10 & 9 & 9 & 9 & 9 & 9 & 9 \\ 936 & 951 & 901 & 894 & 889 & 882 & 885 & 884 \\ 1,753 & 2,010 & 2,012 & 2,013 & 2,015 & 2,012 & 2,015 & 2,015 \\ 2,970 & 3,237 & 3,160 & 3,156 & 3,145 & 3,120 & 3,154 & 3,150\end{array}$

Nonutilities

NA $\quad$ NA $\quad 381 \quad 446 \quad 1,380 \quad 1,500 \quad 1,538 \quad 1,150$

Power Marketers

$\begin{array}{llllllll}\text { NA } & \text { NA } & 155 & 134 & 127 & 136 & 147 & 153\end{array}$

Sources: EIA, The Changing Structure of the Electric Power Industry 2000: An Update (historical); EIA 861 report (1999+ for utilities) - http://www.eia.doe.gov/cneaf/electricity/page/eia861.html; and Form EIA-906 and EIA-920 databases (2001+ for IPPs) - http://www.eia.doe.gov/cneaf/electricity/page/eia906 920.html

\section{Notes:}

${ }^{1}$ Co-ops operate in all states except Connecticut, Hawaii, Rhode Island, and the District of Columbia $\mathrm{NA}=$ not available

1999 and 2000 for nonutilities exclude commercial and industrial generators, while 2001-2004 include commercial and industrial generators. 
Table 5.10 - Top 10 U.S. Investor-Owned Utilities \& Power Marketers

1990

Utility by Sales (Million kWh) Rank Million kWh

Florida Power \& Light Co.

Georgia Power Co.

Duke Energy Corp

Virginia Electric \& Power Co

TXU Electric Co. ${ }^{1}$

Commonwealth Edison Co.

Alabama Power Co.

Pacific Gas \& Electric Co.

Southern California Edison Co.

PacifiCorp

53,953

58,359

52,122

78,340

70,852

38,081

70,597

70,063
Rank Million kWh

40,288

1990

Utility by Revenue (Million \$) Rank Million \$

Florida Power \& Light Co.

26,513

TXU Electric Co. ${ }^{1}$

Consolidated Edison Co-NY Inc $5 \quad 4,385$

Commonwealth Edison Co. 35,668

Virginia Electric \& Power Co. $10 \quad 3,299$

Georgia Power Co.

Duke Energy Corp

Reliant Energy HL\&P ${ }^{1}$
2001

\begin{abstract}
Rank Million \$ Rank
\end{abstract}

$4 \quad 6,065$

$\begin{array}{ll}4 & 6,065 \\ 2 & 6,988\end{array}$

36,433

17,416

$6 \quad 5,286$

$5 \quad 5,723$

94,022

84,283

$12 \quad 3,151$

$7 \quad 4,743$
$3 \quad 7,302$

$4 \quad 7,171$

$2 \quad 7,748$

$1 \quad 7,782$

$6 \quad 5,622$

$5 \quad 5,703$

$7 \quad 4,340$

$8 \quad 4,305$

$9 \quad 4,159$

$10 \quad 5,622$ $\underline{2000}$

Rank Million kWh

88,128

74,434
2001

\begin{tabular}{rr}
2 & 90,495 \\
5 & 72,545 \\
4 & 72,977 \\
7 & 67,858 \\
1 & 102,526 \\
3 & 76,918 \\
9 & 49,338 \\
12 & 46,680 \\
8 & 52,034 \\
11 & 47,708 \\
\hline
\end{tabular}

53,726

65,294

100,885

77,176

52,068

72,121

73,686

$43 \quad 18,859$
2002

Rank Million kWh

195,543

$3 \quad 75,432$

$4 \quad 75,362$

$\underline{2003}$

Rank Million kWh

99,339

75,018

73,763

72,197

79,050

68,384

52,208

47,881

52,229

48,339

$\underline{2003}$

Rank $\frac{2002}{\text { Million } \$}$

27,028

Ran
2004

Rank Million kWh

199,144

77,904

75,775

75,141

71,544

66,419

54,244

53,897

49,123

48,816

$\underline{2004}$

$\underline{2004}$

8,342

6,738

6,434

5,648

5,154

5,028

5,015

4,777

4,502

3,915

${ }^{1}$ In 2002, electric industry restructuring commenced in Texas and both TXU and Reliant became Power Marketers

Source: EIA, Electric Sales and Revenue, DOE/EIA -0540 (00) (Washington, D.C., December 2005), Table 10 (2005) and Table 17 (previous years) 
Table 5.11 - Top 10 Independent Power Producers Worldwide

(Megawatts)

\section{Company}

SUEZ Energy International

(formerly Tractebel Electricity \& Gas Int'I)

AES

ENEL SpA.

Calpine

Dominion Generation

Entergy Wholesale Operations

Reliant

Mirant

NRG Energy

Edison Mission Energy ${ }^{1}$
2002 Capacity (MW) 2003 Capacity (MW) 2004 Capacity (MW)

$\begin{array}{lll}50,000 & 48,317 & 46,841 \\ 55,660 & 44,917 & 44,000 \\ 46,456 & 45,744 & 42,000 \\ 19,319 & 29,891 & 32,149 \\ 23,830 & 24,408 & 28,146 \\ 21,323 & 30,000 & 27,086 \\ 22,349 & 19,442 & 18,737 \\ 22,100 & 23,254 & 17,889 \\ 20,954 & 21,200 & 15,400 \\ 18,688 & 18,733 & 8,834\end{array}$

${ }^{1}$ In 2004, Edison Mission Energy sold most of its international power-generating assets.

Source: Company 10K SEC filings at http://www.sec.gov/ accessed 2/06 
Table 5.12 - Utility Mergers and Acquisitions

\section{$\begin{array}{llllllllll}1994 & 1995 & 1996 & 1997 & 1998 & 1999 & \underline{2000} & \underline{2001} & \underline{2002} & \underline{2003}\end{array}$ \\ $\underline{2004}$}

Mergers/Acquisitions

IOU-IOU

Co-op-Co-op

IOU-Co-op

IOU-Gas ${ }^{1}$

Muni-Muni

Muni-Co-op

Power Authority-IOU

Nonutility-IOU

Nonutility-Muni

TransCo-IOU T assets

Foreign-IOU ${ }^{2}$

Total

4
4

2
2

Related Activities

Name Changes

New Holding Company

Moved Headquarters

Ceased Operations

Source: Calculated from Electrical World, Directory of Electric Power Producers, The McGraw-Hill Companies

\section{Notes:}

${ }^{1}$ Gas local distribution company, pipeline, or developer

${ }^{2}$ Excludes Canadian mergers and acquisitions. Includes foreign acquisition of U.S. companies

${ }^{3}$ Includes pending mergers and acquisitions 
Table 5.13a - North American Electric Reliability Council Map for the United States

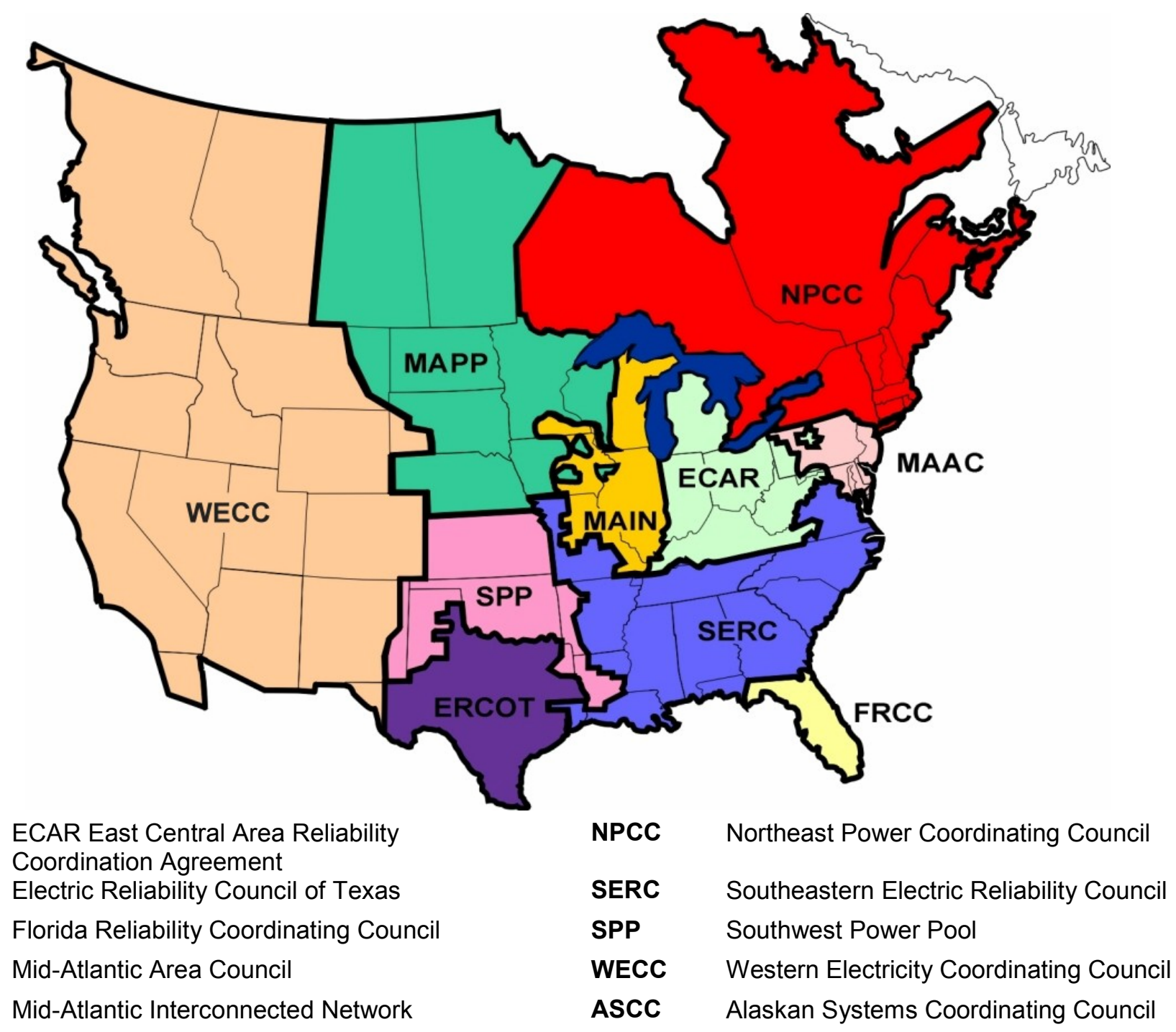

MAPP Mid-Continent Area Power Pool

Source: North American Electric Reliability Council, www.nerc.com 
Table 5.13b - Census Regions

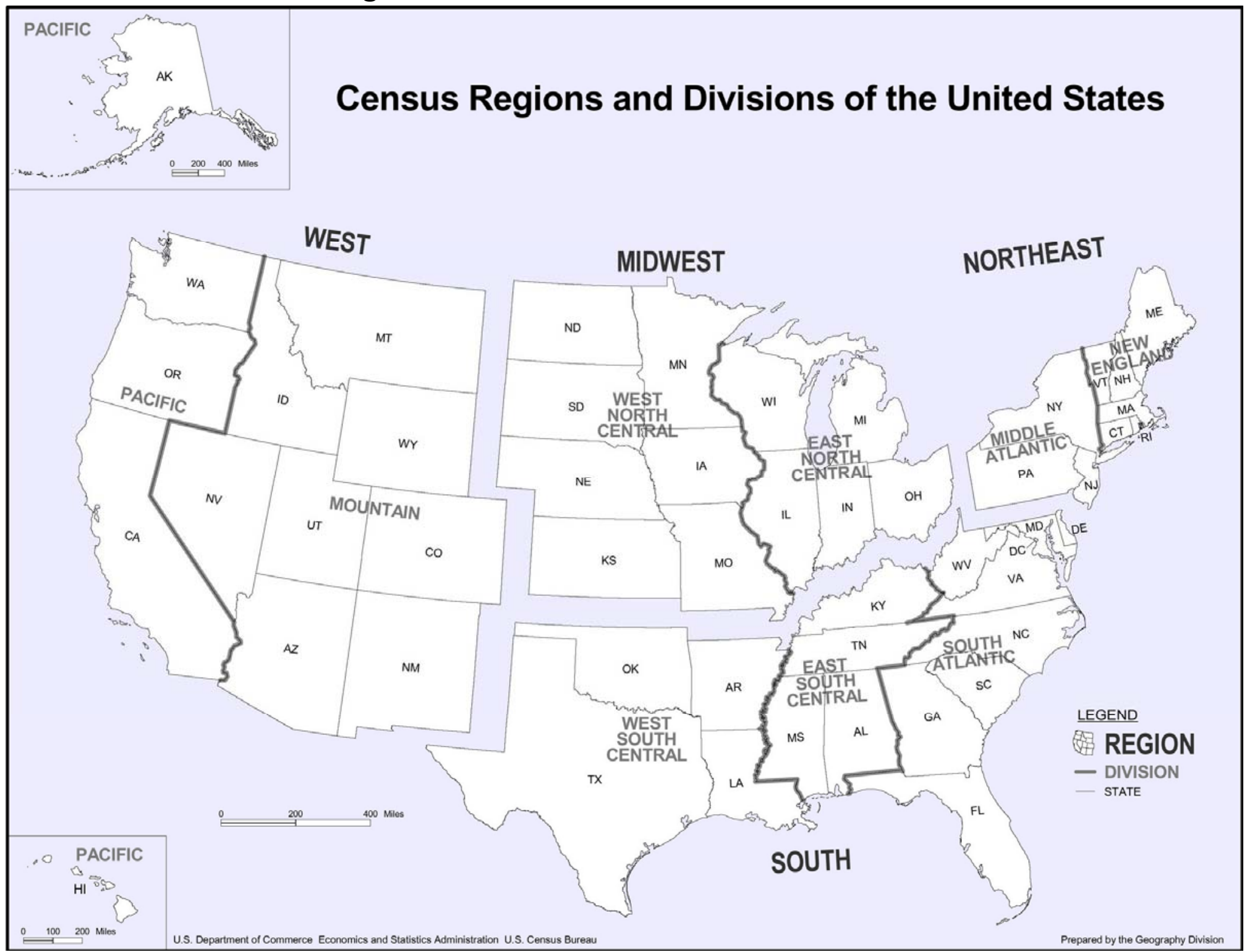

Source: U.S. Department of Commerce, Bureau of the Census, www.census.gov 

Table 6.1 - Electric Net Summer Capability (All Sectors)

(Gigawatts)

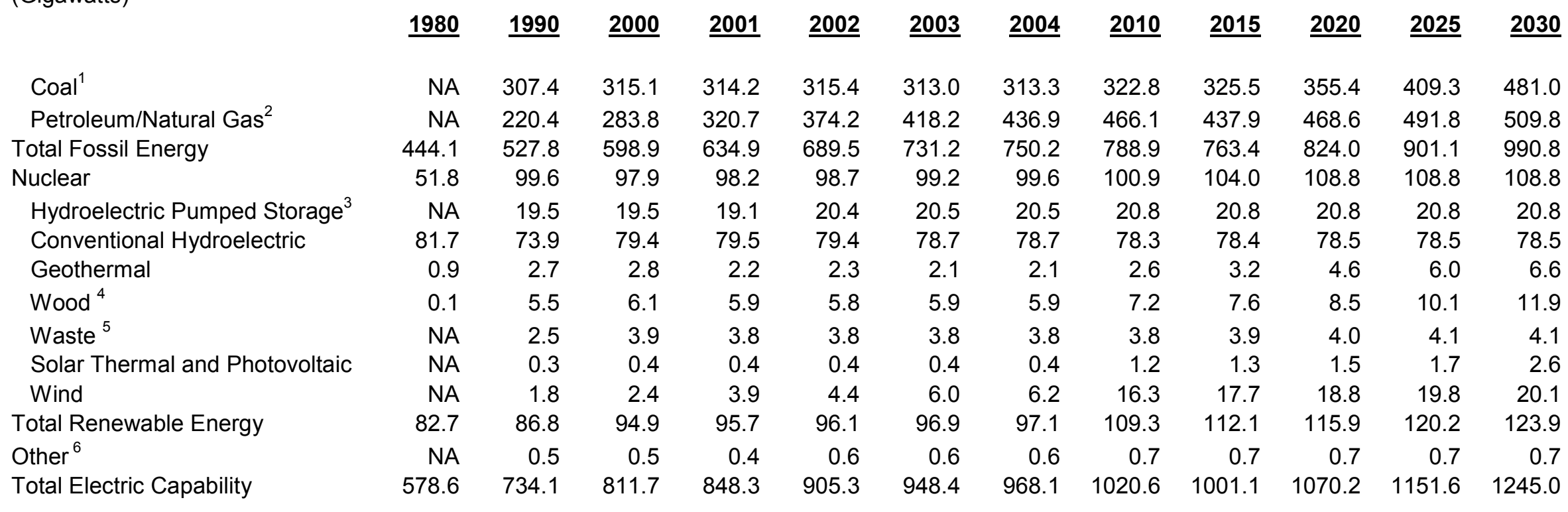

Sources: EIA, Annual Energy Outlook 2006 DOE/EIA-0383 (2006) (Washington, D.C., February 2006), Tables A9, A16; EIA, Annual Energy Review 2004, DOE/EIA-0384(2004) (Washington, D.C., August 2005), Table 8.11a.

\section{Notes:}

Data include electricity-only and combined-heat-and-power (CHP) plants whose primary business is to sell electricity - or electricity and heat - to the public. Through 1988, data are for net summer capacity at electric utilities only. Beginning in 1989, data also include net summer capacity at independent power producers and the commercial and industrial (end-use) sectors.

${ }^{1}$ Anthracite, bituminous coal, subbituminous coal, lignite, waste coal, and synthetic coal.

${ }^{2}$ Petroleum, natural gas, distillate fuel oil, residual fuel oil, petroleum coke, jet fuel, kerosene, other petroleum, waste oil, supplemental gaseous fuels, blast furnace gas, propane gas, and other manufactured and waste gases derived from fossil fuels. Includes natural gas-fired distributed generation.

${ }^{3}$ Pumped storage included in Conventional Hydro prior to 1989.

${ }^{4}$ Wood, black liquor, and other wood waste. Includes projections for energy crops after 2010. Includes other biomass in projections.

${ }^{5}$ Municipal solid waste, landfill gas, sludge waste, tires, agricultural byproducts, and other biomass. Waste included in Wood prior to 1985.

${ }^{6}$ Includes batteries, chemicals, hydrogen, pitch, sulfur, purchased steam, fuel cells, and miscellaneous technologies.

$\mathrm{NA}=$ not available 


\title{
Table 6.2 - Electricity-Only Plant Net Summer Capability
}

\author{
(Gigawatts)
}

\begin{tabular}{|c|c|c|c|c|c|c|c|c|c|c|c|c|}
\hline & $\underline{1980}$ & $\underline{1990}$ & $\underline{2000}$ & $\underline{2001}$ & $\underline{2002}$ & $\underline{2003}$ & $\underline{2004}$ & $\underline{2010}$ & $\underline{2015}$ & $\underline{2020}$ & $\underline{2025}$ & $\underline{2030}$ \\
\hline Petroleum/Natural Gas ${ }^{3}$ & NA & 198.7 & 243.9 & 279.4 & 325.1 & 362.9 & 378.9 & 409.4 & 379.1 & 407.3 & 428.1 & 443.9 \\
\hline Nuclear & NA & 99.6 & 97.9 & 98.2 & 98.7 & 99.2 & 99.6 & 100.9 & 104.0 & 108.8 & 108.8 & 108.8 \\
\hline Hydroelectric Pumped Storage ${ }^{4}$ & NA & 19.5 & 19.5 & 19.1 & 20.4 & 20.5 & 20.5 & 20.8 & 20.8 & 20.8 & 20.8 & 20.8 \\
\hline Conventional Hydroelectric & NA & 73.3 & 78.2 & 78.4 & 78.3 & 77.9 & 77.9 & 77.7 & 77.8 & 77.9 & 77.9 & 77.9 \\
\hline Waste $^{6}$ & NA & 1.9 & 2.8 & 3.0 & 3.0 & 2.8 & 2.9 & 3.5 & 3.7 & 3.8 & 3.8 & 3.9 \\
\hline Solar Thermal and Photovoltaic & NA & 0.3 & 0.4 & 0.4 & 0.4 & 0.4 & 0.4 & 0.5 & 0.6 & 0.7 & 0.8 & $0 . c$ \\
\hline Wind & NA & 1.8 & 2.4 & 3.6 & 4.4 & 6.0 & 6.0 & 16.3 & 17.7 & 18.8 & 19.8 & 20.1 \\
\hline Total Renewable Energy & NA & 80.9 & 88.1 & 89.1 & 89.7 & 90.6 & 90.7 & 102.7 & 105.1 & 108.2 & 111.8 & 114.1 \\
\hline Other & NA & 0.0 & 0.0 & 0.0 & 0.0 & 0.0 & 0.0 & 0.0 & 0.0 & 0.0 & 0.0 & 0.0 \\
\hline Total Electric Capability ${ }^{7}$ & NA & 698.6 & 754.5 & 790.8 & 839.2 & 876.3 & 893.1 & 947.5 & 924.0 & 986.0 & 1055.2 & 1140.7 \\
\hline
\end{tabular}

Sources: EIA, Annual Energy Outlook 2006 DOE/EIA-0383 (2006) (Washington, D.C., February 2006), Tables A9, A16; EIA, Annual Energy Review 2003, DOE/EIA-0384(2003) (Washington, D.C., September 2004), Table 8.11c.

Notes:

Data are for electricity-only plants in the electric-power sector, whose primary business is to sell electricity to the public. Through 1988 , data are for net summer capacity at electric utilities only. Beginning in 1989, data also include net summer capacity at independent power producers.

${ }^{1}$ Anthracite, bituminous coal, subbituminous coal, lignite, waste coal, and synthetic coal.

${ }^{2}$ Petroleum, natural gas, distillate fuel oil, residual fuel oil, petroleum coke, jet fuel, kerosene, other petroleum, waste oil, supplemental gaseous fuels, blast furnace gas, propane gas, and other manufactured and waste gases derived from fossil fuels. Includes natural gas-fired distributed generation.

${ }^{3}$ Pumped storage included in Conventional Hydro prior to 1989.

${ }^{4}$ Wood, black liquor, and other wood waste. Includes projections for energy crops after 2010. Includes other biomass in projections.

${ }^{5}$ Municipal solid waste, landfill gas, sludge waste, tires, agricultural byproducts, and other biomass. Waste included in Wood prior to 1985.

${ }^{6}$ Includes batteries, chemicals, hydrogen, pitch, sulfur, purchased steam, fuel cells, and miscellaneous technologies.

$\mathrm{NA}=$ not available 


\section{Table 6.3 - Combined-Heat-and-Power Plant Net Summer Capability}

(Gigawatts)

\begin{tabular}{|c|c|c|c|c|c|c|c|c|c|c|c|c|}
\hline & $\underline{1980}$ & 1990 & $\underline{2000}$ & $\underline{2001}$ & $\underline{2002}$ & $\underline{2003}$ & $\underline{2004}$ & $\underline{2010}$ & $\underline{2015}$ & $\underline{2020}$ & $\underline{2025}$ & $\underline{2030}$ \\
\hline Coal $^{2}$ & NA & 7.5 & 10.0 & 9.1 & 9.5 & 10.0 & 9.9 & 9.1 & 10.5 & 14.5 & 23.6 & 27.9 \\
\hline Petroleum/Natural Gas ${ }^{3}$ & NA & 21.7 & 39.9 & 41.3 & 49.1 & 55.3 & 58.0 & 56.7 & 58.7 & 61.4 & 63.7 & 65.9 \\
\hline Total Fossil Energy & NA & 29.2 & 49.9 & 50.4 & 58.6 & 65.3 & 67.9 & 65.8 & 69.3 & 75.9 & 87.3 & 93.8 \\
\hline Nuclear & NA & 0.0 & 0.0 & 0.0 & 0.0 & 0.0 & 0.0 & 0.0 & 0.0 & 0.0 & 0.0 & 0.0 \\
\hline Hydroelectric Pumped Storage & NA & 0.0 & 0.0 & 0.0 & 0.0 & 0.0 & 0.0 & 0.0 & 0.0 & 0.0 & 0.0 & 0.0 \\
\hline Conventional Hydroelectric & NA & 0.6 & 1.1 & 1.1 & 1.1 & 0.8 & 0.8 & 0.7 & 0.7 & 0.7 & 0.7 & 0.7 \\
\hline Geothermal & NA & 0.0 & 0.0 & 0.0 & 0.0 & 0.0 & 0.0 & 0.0 & 0.0 & 0.0 & 0.0 & 0.0 \\
\hline Wood $^{4}$ & NA & 4.6 & 4.9 & 4.6 & 4.7 & 4.7 & 4.8 & 5.0 & 5.5 & 6.0 & 6.6 & 7.3 \\
\hline Waste ${ }^{5}$ & NA & 0.4 & 0.6 & 0.5 & 0.5 & 0.5 & 0.5 & 0.3 & 0.3 & 0.3 & 0.3 & 0.3 \\
\hline Solar Thermal and Photovoltaic & NA & 0.0 & 0.0 & 0.0 & 0.0 & 0.0 & 0.0 & 0.6 & 0.7 & 0.8 & 0.9 & 1.7 \\
\hline Wind & NA & 0.0 & 0.0 & 0.3 & 0.0 & 0.0 & 0.0 & 0.0 & 0.0 & 0.0 & 0.0 & 0.0 \\
\hline Total Renewable Energy & NA & 5.3 & 6.1 & 5.8 & 5.8 & 5.6 & 5.6 & 7.0 & 7.5 & 8.1 & 8.8 & 10.3 \\
\hline Other & NA & 0.5 & 0.5 & 0.4 & 0.6 & 0.6 & 0.6 & 0.7 & 0.7 & 0.7 & 0.7 & 0.7 \\
\hline Total Electric Capability ${ }^{6}$ & NA & 35.5 & 57.2 & 57.4 & 65.6 & 72.1 & 75.0 & 73.4 & 77.5 & 84.7 & 96.8 & 104.8 \\
\hline
\end{tabular}

Sources: EIA, Annual Energy Outlook 2006 DOE/EIA-0383 (2006) (Washington, D.C., February 2006), Tables A9, A16; EIA, Annual Energy Review 2004, DOE/EIA-0384(2004) (Washington, D.C., August 2005), Table 8.11c.

Notes:

Includes combined-heat-and-power (CHP) plants whose primary business is to sell electricity and heat to the public. Includes electric utility CHP plants. Also includes commercial and industrial CHP and a small number of commercial electricity-only plants.

${ }^{1}$ Anthracite, bituminous coal, subbituminous coal, lignite, waste coal, and synthetic coal.

${ }^{2}$ Petroleum, natural gas, distillate fuel oil, residual fuel oil, petroleum coke, jet fuel, kerosene, other petroleum, waste oil, supplemental gaseous fuels, blast furnace gas, propane gas, and other manufactured and waste gases derived from fossil fuels. Includes natural gas fired distributed generation.

${ }^{3}$ Pumped storage included in Conventional Hydro prior to 1989.

${ }^{4}$ Wood, black liquor, and other wood waste. Includes projections for energy crops after 2010. Includes other biomass in projections.

${ }^{5}$ Municipal solid waste, landfill gas, sludge waste, tires, agricultural byproducts, and other biomass. Waste included in Wood prior to 1985.

${ }^{6}$ Includes batteries, chemicals, hydrogen, pitch, sulfur, purchased steam, fuel cells, and miscellaneous technologies.

NA = not available 


\section{Table 6.4 - Regional Noncoincident ${ }^{1}$ Peak Loads and Capacity Margin}

(Megawatts, except as noted)

\begin{tabular}{|c|c|c|c|c|c|c|c|c|c|c|c|c|}
\hline rt & 年 & . & (1). & & & & & & & & & \\
\hline ECAR & 79,258 & 92,033 & 100,235 & 102,996 & 98,487 & 102,423 & 67,097 & 84,546 & 85,485 & 87,300 & 86,332 & 87,972 \\
\hline ERCOT & 42,737 & 57,606 & 55,201 & 56,248 & 59,996 & 61,432 & 35,815 & 44,641 & 44,015 & 45,414 & 42,702 & 43,556 \\
\hline FRCC & NA & 37,194 & 39,062 & 40,696 & 40,475 & 42,705 & NA & 38,606 & 40,922 & 45,635 & 36,841 & 45,418 \\
\hline MAAC & 42,613 & 49,477 & 54,015 & 55,569 & 53,566 & 56,886 & 36,551 & 43,256 & 39,458 & 46,551 & 45,625 & 45,471 \\
\hline MAIN & 40,740 & 52,552 & 56,344 & 56,396 & 56,988 & 57,868 & 32,461 & 41,943 & 40,529 & 42,412 & 41,719 & 42,409 \\
\hline SERC & 121,943 & 156,088 & 149,293 & 158,767 & 153,110 & 157,961 & 117,448 & 139,146 & 135,182 & 141,882 & 137,972 & 141,176 \\
\hline SPP & 52,541 & 40,199 & 40,273 & 39,688 & 40,367 & 40,089 & 38,949 & 30,576 & 29,614 & 30,187 & 28,450 & 28,469 \\
\hline WECC $^{2}$ (U.S.) & 97,389 & 114,602 & 109,119 & 119,074 & 122,537 & 122,870 & 94,252 & 97,324 & 96,622 & 95,951 & 102,020 & 104,393 \\
\hline Contiguous U.S. & 546,331 & 678,413 & 687,812 & 714,565 & 709,375 & 729,013 & 484,231 & 588,426 & 576,312 & 604,986 & 593,874 & 611,478 \\
\hline ASCC (Alaska) & 463 & NF & NF & $\mathrm{NF}$ & NF & NF & 613 & NF & NF & NF & $\mathrm{NF}$ & NF \\
\hline Hawaii & $\mathrm{NF}$ & NF & NF & $N F$ & NF & NF & NF & NF & NF & NF & NF & NF \\
\hline
\end{tabular}

Source: EIA, Annual Energy Review 2003, DOE/EIA-0384(2003) (Washington, D.C., September 2004), Table 8.12.

\section{Notes:}

$\mathrm{NF}=$ data not filed, $\mathrm{NA}=$ not available

2003 data are forecast estimates.

${ }^{1}$ Noncoincident peak load is the sum of two or more peak loads on individual systems that do not occur at the same time interval.

${ }^{2}$ Renamed from WSCC in 2002

${ }^{3}$ The percent by which planned generating capacity resources are expected to be greater (or less) than estimated net internal demand at the time of expected peak summer (or winter) demand. Net internal demand does not include estimated demand for direct control load management and customers with interruptible service agreements. 
Table 6.5 - Electric-Generator Cumulative Additions and Retirements

(Gigawatts) $^{1}$

$\underline{2010} \underline{2015} \quad \underline{2020} \quad \underline{2025} \quad \underline{2030}$

\section{Cumulative Planned}

Additions

Coal Steam

Other Fossil Steam ${ }^{2}$

Combined Cycle

Combustion Turbine/Diesel

Nuclear

Pumped Storage

Fuel Cells

Renewable Sources ${ }^{3}$

Distributed Generation ${ }^{4}$

Total Planned Additions

$\begin{array}{rrrrr}8.3 & 9.3 & 9.3 & 9.3 & 9.3 \\ 0.1 & 0.1 & 0.1 & 0.1 & 0.1 \\ 25.7 & 25.7 & 25.7 & 25.7 & 25.7 \\ 5.3 & 5.3 & 5.3 & 5.3 & 5.3 \\ 0.0 & 0.0 & 0.0 & 0.0 & 0.0 \\ 0.0 & 0.0 & 0.0 & 0.0 & 0.0 \\ 0.0 & 0.0 & 0.0 & 0.0 & 0.0 \\ 10.0 & 11.0 & 11.1 & 11.2 & 11.4 \\ 0.0 & 0.0 & 0.0 & 0.0 & 0.0 \\ 49.4 & 51.5 & 51.6 & 51.7 & 51.8\end{array}$

\begin{tabular}{|c|c|c|c|c|c|}
\hline \multicolumn{6}{|l|}{$\begin{array}{l}\text { Cumulative Unplanned } \\
\text { Additions }\end{array}$} \\
\hline Coal Steam & 3.4 & 7.0 & 32.9 & 77.7 & 145.1 \\
\hline Other Fossil Steam $^{2}$ & 0.0 & 0.0 & 0.0 & 0.0 & 0.0 \\
\hline Combined Cycle & 0.0 & 5.5 & 29.9 & 41.9 & 46.8 \\
\hline Combustion Turbine/Diesel & 4.7 & 11.6 & 21.5 & 31.3 & 46.2 \\
\hline Nuclear & 0.0 & 2.2 & 6.0 & 6.0 & 6.0 \\
\hline Pumped Storage & 0.0 & 0.0 & 0.0 & 0.0 & 0.0 \\
\hline Fuel Cells & 0.0 & 0.0 & 0.0 & 0.0 & 0.0 \\
\hline Renewable Sources $^{3}$ & 0.4 & 1.7 & 4.8 & 8.3 & 10.4 \\
\hline Distributed Generation $^{4}$ & 0.2 & 0.6 & 1.4 & 2.4 & 5.5 \\
\hline Total Unplanned Additions & 8.8 & 28.6 & 96.5 & 167.7 & 260.0 \\
\hline \multicolumn{6}{|l|}{ Cumulative Retirements } \\
\hline Coal Steam & 3.0 & 6.8 & 6.8 & 6.8 & 6.8 \\
\hline Other Fossil Steam ${ }^{2}$ & 2.0 & 37.9 & 44.0 & 45.1 & 49.0 \\
\hline Combined Cycle & 0.6 & 0.6 & 0.6 & 0.6 & 0.6 \\
\hline Combustion Turbine/Diesel & 1.4 & 8.2 & 8.2 & 8.2 & 8.2 \\
\hline Nuclear & 0.0 & 0.0 & 0.0 & 0.0 & 0.0 \\
\hline Pumped Storage & 0.0 & 0.0 & 0.0 & 0.0 & 0.0 \\
\hline Fuel Cells & 0.0 & 0.0 & 0.0 & 0.0 & 0.0 \\
\hline Renewable Sources ${ }^{3}$ & 0.1 & 0.1 & 0.1 & 0.1 & 0.1 \\
\hline Total Retirements & 7.1 & 53.6 & 59.8 & 60.8 & 64.7 \\
\hline
\end{tabular}

Sources: EIA, Annual Energy Outlook 2006, DOE/EIA-0383 (2006) (Washington, D.C., February 2006), Table A9.

Notes:

${ }^{1}$ Additions and retirements since December 31, 2001.

2 Includes oil-, gas-, and dual-fired capability.

${ }^{3}$ Includes conventional hydroelectric, geothermal, wood, wood waste, municipal solid waste, landfill gas, other biomass, solar, and wind power.

${ }^{4}$ Primarily peak load capacity fueled by natural gas. 


\begin{tabular}{|c|c|c|c|c|c|c|c|c|}
\hline $\begin{array}{l}\text { Voltage } \\
\text { (kilovolts) }\end{array}$ & $\underline{1980}$ & $\underline{1990}$ & $\underline{1999}$ & $2000^{2}$ & $\underline{2001}^{2}$ & $2002^{2}$ & $2003^{2}$ & $2004^{2}$ \\
\hline 230 & NA & 70,511 & 76,762 & 76,437 & 80,515 & 81,252 & 82,238 & 81,992 \\
\hline 345 & NA & 47,948 & 49,250 & 51,025 & 53,855 & 54,827 & 54,195 & 55,429 \\
\hline 500 & NA & 23,958 & 26,038 & 25,000 & 27,343 & 27,587 & 27,407 & 28,011 \\
\hline 765 & NA & 2,428 & 2,453 & 2,426 & 2,518 & 2,560 & 2,560 & 2,560 \\
\hline Total & NA & 144,845 & 154,503 & 154,888 & 164,231 & 166,226 & 166,400 & 167,992 \\
\hline
\end{tabular}

Sources: EIA, Electricity Transmission Fact Sheets, http://www.eia.doe.gov/cneaf/electricity/page/fact_sheets/transmission.html; NERC, Electricity Supply and Demand Database, 2005, http://www.nerc.com/ esd/Brochure.pdf

Notes:

${ }^{1}$ Circuit miles of $\mathrm{AC}$ lines $230 \mathrm{kV}$ and above.

${ }^{2}$ Data includes both existing and planned transmission lines 


\section{Table 7.1 - Electricity Net Generation}

(Billion Kilowatthours)

\begin{tabular}{|c|c|c|c|c|c|c|c|c|c|c|c|}
\hline$\underline{1980}$ & $\underline{1990}$ & $\underline{2000}$ & $\underline{2001}$ & $\underline{2002}$ & $\underline{2003}$ & $\underline{2004}$ & $\underline{2010}$ & $\underline{2015}$ & $\underline{2020}$ & $\underline{2025}$ & 2030 \\
\hline 1,162 & 1,594 & 1,966 & 1,904 & 1,933 & 1,974 & 1,976 & 2,218 & 2,277 & 2,505 & 2,896 & 3,381 \\
\hline 246 & 127 & 111 & 125 & 95 & 119 & 118 & 105 & 104 & 107 & 108 & \\
\hline 346 & 373 & 601 & 639 & 691 & 650 & 700 & 774 & 1,018 & 1,102 & $\begin{array}{l}1,069 \\
0\end{array}$ & 1590 \\
\hline NA & 10 & 14 & 9 & 11 & 16 & 15 & 12 & & 12 & 12 & \\
\hline 1,754 & 2,104 & 2,692 & 2,677 & 2,730 & 2,759 & 2,809 & 3,108 & $3,4 \uparrow 1$ & 3,725 & 4,085 & 4,497 \\
\hline 251 & 577 & 754 & 769 & 780 & 764 & 789 & 809 & 829 & 871 & $87^{\prime}$ & \\
\hline NA & -4 & -6 & -9 & -9 & -9 & -8 & -9 & -9 & -9 & $\begin{array}{l}0 \\
0\end{array}$ & \\
\hline 279 & 293 & 276 & 217 & 264 & 276 & 270 & 301 & 302 & 303 & 303 & \\
\hline 5 & 15 & 14 & 14 & 14 & 14 & 14 & 18 & & & 47 & \\
\hline 0 & 33 & 38 & 35 & 39 & 38 & 37 & 76 & 79 & 86 & 103 & \\
\hline 0 & 13 & 23 & 22 & 23 & 24 & 23 & 27 & 28 & 29 & 30 & \\
\hline NA & 0 & 0 & 1 & 1 & 1 & 1 & 2 & $20_{0}$ & 3 & & \\
\hline NA & 3 & 6 & 7 & 10 & 11 & 14 & 51 & & & 3 & 65 \\
\hline 285 & 357 & 356 & 295 & 351 & 363 & 359 & 476 & 491 & 515 & 54 & \\
\hline NA & NA & NA & NA & NA & NA & NA & -177 & -192 & -214 & -252 & \\
\hline NA & 4 & 5 & 5 & 6 & 6 & 6 & 12 & & 12 & 12 & \\
\hline 2,290 & 3,038 & 3,802 & 3,737 & 3,858 & 3,883 & 3,953 & 4,388 & 4,727 & 5,108 & 5,491 & 5,926 \\
\hline
\end{tabular}

Coal ${ }^{1}$
Petroleum $^{2}$
Natural Gas $^{3}$
Other Gases $^{4}$
Total Fossil Energy
Nuclear
Hydroelectric Pumped Storage $^{5}$
Conventional Hydroelectric $^{6}$
Geothermal $^{7}$
Wood
${ }^{7}$
Waste
Solar Thermal and Photovoltaic
Wind
Total Renewable Energy
Generation for Own Use
${ }^{8}$
Other ${ }^{10}$
Total Electricity Generation

Sources: EIA, Annual Energy Review 2004, DOE/EIA-0384(2004) (Washington, D.C., August 2005), Table 8.2a; and EIA, Annual Energy Outlook 2006, DOE/EIA-0383(2006) (Washington, D.C., February 2006), Tables A8 and A16.

\section{Notes:}

Data include electricity-only and combined-heat-and-power (CHP) plants, whose primary business is to sell electricity - or electricity and heat - to the public. Through 1988, data are for generation at electric utilities only. Beginning in 1989, data also include generation at independent power producers and the commercial and industrial (end-use) sectors.

${ }^{1}$ Anthracite, bituminous coal, subbituminous coal, lignite, waste coal, and synthetic coal.

${ }^{2}$ Distillate fuel oil, residual fuel oil, petroleum coke, jet fuel, kerosene, other petroleum, and waste oil.

${ }^{3}$ Natural gas, including a small amount of supplemental gaseous fuels. Forecast data include electricity generation from fuel cells.

${ }^{4}$ Blast furnace gas, propane gas, and other manufactured and waste gases derived from fossil fuels (including refinery and still gas).

${ }^{5}$ Pumped-storage facility production, minus energy used for pumping. Data for 1980 included in conventional hydroelectric power.

${ }^{6}$ Hydroelectric data through 1988 are for generation at electric utilities and industrial plants only; beginning in 1989, data also include generation at independent power producers and commercial plants.

${ }^{7}$ Wood, black liquor, and other wood waste.

${ }_{9}^{8}$ Municipal solid waste, landfill gas, sludge waste, tires, agricultural byproducts, and other biomass.

${ }^{9}$ Includes nonutility and end-use sector generation for own use.

${ }^{10}$ Batteries, chemicals, hydrogen, pitch, purchased steam, sulfur, and miscellaneous technologies.

$\mathrm{NA}=$ not available 
Table 7.2 - Net Generation at Electricity-Only Plants

(Billion Kilowatthours)

\begin{tabular}{|c|c|c|c|c|c|c|c|c|c|c|c|c|}
\hline & $\underline{1980}$ & $\underline{1990}$ & $\underline{2000}$ & $\underline{2001}$ & $\underline{2002}$ & $\underline{2003}$ & $\underline{2004}$ & $\underline{2010}$ & $\underline{2015}$ & $\underline{2020}$ & $\underline{2025}$ & $\underline{2030}$ \\
\hline Coal $^{1}$ & 1,162 & 1,560 & 1,911 & 1,852 & 1,881 & 1,916 & 1,916 & 2,164 & 2,209 & 2,405 & 2,728 & 3,178 \\
\hline Petroleum $^{2}$ & 246 & 118 & 98 & 113 & 83 & 109 & 108 & 90 & 89 & 90 & 93 & 99 \\
\hline Natural Gas ${ }^{3}$ & 346 & 265 & 399 & 427 & 457 & 421 & 486 & 533 & 743 & 814 & 775 & 691 \\
\hline Other Gases ${ }^{4}$ & NA & 0 & 0 & 0 & 0 & 0 & 0 & NA & NA & NA & NA & NA \\
\hline Total Fossil Energy & 1,754 & 1,942 & 2,408 & 2,392 & 2,422 & 2,446 & 2,510 & 2,787 & 3,041 & 3,310 & 3,596 & 3,968 \\
\hline Nuclear & 251 & 577 & 754 & 769 & 780 & 764 & 789 & 809 & 829 & 871 & 871 & 871 \\
\hline Hydroelectric Pumped Storage ${ }^{5}$ & NA & -4 & -6 & -9 & -9 & -9 & -8 & -9 & -9 & -9 & -9 & -9 \\
\hline Conventional Hydroelectric ${ }^{6}$ & 276 & 290 & 271 & 214 & 260 & 272 & 264 & 297 & 297 & 298 & 299 & 299 \\
\hline Geothermal & 5 & 15 & 14 & 14 & 14 & 14 & 14 & 18 & 23 & 34 & 47 & 53 \\
\hline Wood $^{7}$ & 0.3 & 6 & 7 & 7 & 7 & 7 & 7 & 45 & 45 & 49 & 51 & 58 \\
\hline Waste ${ }^{8}$ & 0.2 & 10 & 18 & 17 & 17 & 18 & 18 & 25 & 26 & 27 & 28 & 28 \\
\hline Solar Thermal and Photovoltaic & NA & 0.4 & 0.5 & 0.5 & 0.6 & 0.5 & 0.6 & 1 & 1 & 1 & 2 & 2 \\
\hline Wind & NA & 3 & 6 & 7 & 10 & 11 & 14 & 51 & 56 & 60 & 63 & 65 \\
\hline Total Renewable Energy & 282 & 324 & 316 & 259 & 311 & 323 & 319 & 436 & 448 & 469 & 489 & 504 \\
\hline Other ${ }^{10}$ & 0 & 0 & 0 & 0 & 1 & 1 & 3 & NA & NA & NA & NA & NA \\
\hline Total Electricity Generation & 2,286 & 2,840 & 3,473 & 3,411 & 3,505 & 3,525 & 3,611 & 4,020 & 4,306 & 4,638 & 4,945 & 5,332 \\
\hline
\end{tabular}

Sources: EIA, Annual Energy Review 2004, DOE/EIA-0384(2004) (Washington, D.C., August 2005),Table 8.2c; and EIA, Annual Energy Outlook 2006, DOE/EIA-0383(2006) (Washington, D.C., February 2006), Tables A8 and A16.

Notes:

Data are for electricity-only plants in the electric-power sector whose primary business is to sell electricity to the public. Through 1988 , data are for generation at electric utilities only. Beginning in 1989, data also include generation at independent power producers.

${ }^{1}$ Anthracite, bituminous coal, subbituminous coal, lignite, waste coal, and synthetic coal.

${ }^{2}$ Distillate fuel oil, residual fuel oil, petroleum coke, jet fuel, kerosene, other petroleum, and waste oil.

${ }^{3}$ Natural gas, including a small amount of supplemental gaseous fuels. Forecast data include electricity generation from fuel cells.

${ }_{5}^{4}$ Blast furnace gas, propane gas, and other manufactured and waste gases derived from fossil fuels (including refinery and still gas).

${ }^{5}$ Pumped-storage facility production, minus energy used for pumping. Data for 1980 included in conventional hydroelectric power.

${ }^{6}$ Hydroelectric data through 1988 are for generation at electric utilities and industrial plants only; beginning in 1989, data also include generation at independent power producers and commercial plants.

${ }^{7}$ Wood, black liquor, and other wood waste.

${ }^{8}$ Municipal solid waste, landfill gas, sludge waste, tires, agricultural byproducts, and other biomass.

${ }^{9}$ Includes nonutility and end-use sector generation for own use.

${ }^{10}$ Batteries, chemicals, hydrogen, pitch, purchased steam, sulfur, and miscellaneous technologies.

$\mathrm{NA}=$ not available 
Table 7.3 - Electricity Generation at Combined-Heat-and-Power Plants

(Billion Kilowatthours)

\begin{tabular}{|c|c|c|c|c|c|c|c|c|c|c|c|c|}
\hline & $\underline{1980}$ & $\underline{1990}$ & $\underline{2000}$ & $\underline{2001}$ & $\underline{2002}$ & $\underline{2003}$ & $\underline{2004}$ & $\underline{2010}$ & $\underline{2015}$ & $\underline{2020}$ & $\underline{2025}$ & $\underline{2030}$ \\
\hline Coal $^{1}$ & NA & 34 & 56 & 52 & 52 & 58 & 61 & 53 & 68 & 99 & 168 & 203 \\
\hline Petroleum $^{2}$ & NA & 9 & 13 & 12 & 11 & 11 & 10 & 15 & 15 & 17 & 15 & 16 \\
\hline Natural Gas ${ }^{3}$ & NA & 108 & 202 & 212 & 234 & 229 & 213 & 241 & 275 & 288 & 294 & 299 \\
\hline Other Gases ${ }^{4}$ & NA & 10 & 14 & 9 & 11 & 15 & 15 & 4 & 4 & 5 & 5 & 5 \\
\hline Total Fossil Energy & NA & 161 & 284 & 285 & 309 & 313 & 299 & 313 & 363 & 408 & 482 & 522 \\
\hline Nuclear & NA & 0 & 0 & 0 & 0 & 0 & 0 & 0 & 0 & 0 & 0 & 0 \\
\hline Hydroelectric Pumped Storage ${ }^{5}$ & NA & 0 & 0 & 0 & 0 & 0 & 0 & 0 & 0 & 0 & 0 & 0 \\
\hline Conventional Hydroelectric ${ }^{6}$ & NA & 3 & 4 & 3 & 4 & 4 & 5 & 4 & 4 & 4 & 4 & 4 \\
\hline Geothermal & NA & 0 & 0 & 0 & 0 & 0 & 0 & 0 & 0 & 0 & 0 & 0 \\
\hline Wood $^{7}$ & NA & 27 & 30 & 29 & 31 & 30 & 30 & 32 & 35 & 38 & 51 & 45 \\
\hline Waste $^{8}$ & NA & 3 & 6 & 5 & 5 & 6 & 5 & 2 & 2 & 2 & 2 & 2 \\
\hline Solar Thermal and Photovoltaic & NA & 0 & 0 & 0 & 0 & 0 & 0 & 1 & 1 & 2 & 2 & 4 \\
\hline Wind & NA & 0 & 0 & 0 & 0 & 0 & 0 & 0 & 0 & 0 & 0 & 0 \\
\hline Total Renewable Energy & NA & 33 & 40 & 36 & 41 & 40 & 40 & 40 & 43 & 46 & 50 & 55 \\
\hline Other ${ }^{9}$ & NA & 4 & 5 & 5 & 4 & 5 & 3 & 12 & 12 & 12 & 12 & 12 \\
\hline Total Electricity Generation & NA & 198 & 329 & 326 & 354 & 358 & 342 & 364 & 417 & 466 & 543 & 589 \\
\hline
\end{tabular}

Sources: EIA, Annual Energy Review 2004, DOE/EIA-0384(2004) (Washington, D.C., August 2005), Table 8.2c and 8.2d; and EIA, Annual Energy Outlook 2006, DOE/EIA-0383(2006) (Washington, D.C., February 2006), Tables A8 and A16.

Notes:

Includes combined-heat-and-power (CHP) plants, whose primary business is to sell electricity and heat to the public. Includes electric utility CHP plants. Also includes commercial and industrial CHP and a small number of commercial and industrial (end-use sectors) electricity-only plants.

${ }^{1}$ Anthracite, bituminous coal, subbituminous coal, lignite, waste coal, and synthetic coal.

${ }^{2}$ Distillate fuel oil, residual fuel oil, petroleum coke, jet fuel, kerosene, other petroleum, and waste oil.

${ }^{3}$ Natural gas, plus a small amount of supplemental gaseous fuels that cannot be identified separately. Forecast data include electricity generation from fuel cells.

${ }^{4}$ Blast furnace gas, propane gas, and other manufactured and waste gases derived from fossil fuels (including refinery and still gas).

${ }^{5}$ Pumped-storage facility production, minus energy used for pumping.

${ }^{6}$ Includes CHP plants that use multiple sources of energy, including hydropower.

${ }^{7}$ Wood, black liquor, and other wood waste.

${ }^{8}$ Municipal solid waste, landfill gas, sludge waste, tires, agricultural byproducts, and other biomass.

${ }^{9}$ Batteries, chemicals, hydrogen, pitch, purchased steam, sulfur, and miscellaneous technologies.

NA = not available 
Table 7.4 - Generation and Transmission/Distribution Losses

(Billion kWh)

$\begin{array}{rrrrrrrrrrrr}\underline{\mathbf{1 9 8 0}} & \underline{\mathbf{1 9 9 0}} & \underline{\mathbf{2 0 0 0}} & \underline{\mathbf{2 0 0 1}} & \underline{\underline{\mathbf{2 0 0 2}}} & \underline{\underline{\mathbf{2 0 0 3}}} & \underline{\mathbf{2 0 0 4}} & \underline{\mathbf{2 0 1 0}} & \underline{\mathbf{2 0 1 5}} & \underline{\mathbf{2 0 2 0}} & \underline{\mathbf{2 0 2 5}} & \underline{\mathbf{2 0 3 0}} \\ 2,290 & 3,038 & 3,802 & 3,737 & 3,858 & 3,883 & 3,953 & 4,211 & 4,536 & 4,893 & 5,240 & 5,648 \\ 4,859 & 6,316 & 7,809 & 7,617 & 7,798 & 7,756 & 8,006 & 8,339 & 8,764 & 9,232 & 9,652 & 10,094 \\ \text { NA } & 219 & 258 & 243 & 266 & 257 & 271 & 251 & 254 & 274 & 294 & 317\end{array}$

Sources: Calculated from EIA, Annual Energy Review 2004, DOE/EIA-0384(2004) (Washington, D.C., August 2005), Tables 8.1, 8.2a, and 8.4a; and EIA, Annual Energy Outlook 2006, DOE/EIA-0383(2006) (Washington, D.C., February 2006), Tables A2 and A8.

Notes:

${ }^{1}$ Generation Losses for all years are calculated by calculating a Gross Generation value in billion kWh by multiplying the energy input in trillion Btu by (1000/3412) and subtracting the Net Generation in billion kWh from the Gross Generation estimate.

2 Transmission and Distribution Losses= Electricity Needed to be Transmitted- Electricity Sales, where Electricity Needed to be Transmitted = Total Generation from Electric Generators + Cogenerators + Net Imports - Generation for Own Use. Represents energy losses that occur between the point of generation and delivery to the customer, and data collection frame differences and nonsampling error.

$\mathrm{NA}=$ not available 


\section{Table 7.5 - Electricity Trade}

(Billion Kilowatthours)

Interregional Electricity Trade

Gross Domestic Firm Power Trade

Gross Domestic Economy Trade

$\begin{array}{rrrrrrrrrrrr}\text { NA } & \text { NA } & \text { NA } & 143 & 139 & 137 & 142 & 105 & 82 & 51 & 38 & 38 \\ \text { NA } & \text { NA } & \text { NA } & 182 & 174 & 215 & 233 & 231 & 200 & 168 & 165 & 158 \\ \text { NA } & \text { NA } & \text { NA } & 325 & 313 & 352 & 376 & 337 & 283 & 219 & 203 & 196\end{array}$

International Electricity Trade

Firm Power Imports from Mexico and

Canada

Economy Imports from Mexico and

Canada

Gross Imports from Mexico and Canada

$\begin{array}{rrr}\text { NA } & \text { NA } & \text { NA } \\ \text { NA } & \text { NA } & \text { NA } \\ 25 & 18 & 49 \\ & & \\ \text { NA } & \text { NA } & \text { NA } \\ \text { NA } & \text { NA } & \text { NA } \\ 4 & 16 & 15\end{array}$

1210

$10 \quad 11$

26

27

19

123

2

$22 \quad 40$

39

$\begin{array}{lll}29 & 27 & 26\end{array}$

Firm Power Exports to Mexico and Canada

Economy Exports to Mexico and Canada

Gross Exports to Canada and Mexico

4

$\begin{array}{rrr}7 & 6 & 5 \\ 10 & 9 & 19 \\ 16 & 14 & 24\end{array}$

7
16
23

1
20

1
17
18

Sources: EIA, Annual Energy Review 2004, DOE/EIA-0384(2004) (Washington, D.C., August 2005), Table 8.1; and EIA, Annual Energy Outlook 2006, DOE/EIA-0383(2006) (Washington, D.C., February 2006), Table A10.

Notes:

All data are from EIA AEO except Gross Imports and Exports for 1980-2004.

$\mathrm{NA}=$ not available 


\section{Table 8.1 - Electricity Sales}

(Billion Kilowatthours)

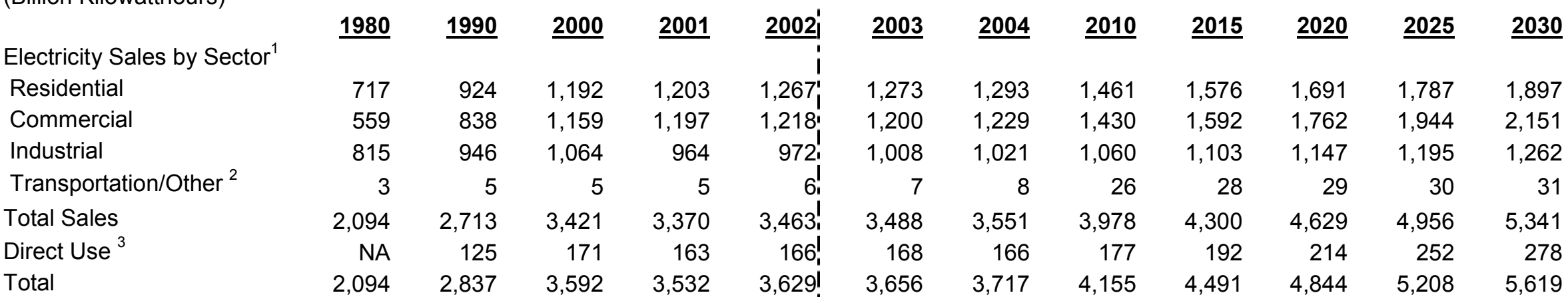

Sources: 2010-2030 - EIA, Annual Energy Outlook 2006, DOE/EIA-0383(2006) (Washington, D.C., February 2006), Table A8; 1980-2004 - EIA, Annual Energy Review 2004, DOE/EIA-0384(2004) (Washington, D.C., August 2005), Table 8.9.

\section{Notes:}

${ }^{1}$ Electricity retail sales to ultimate customers reported by electric utilities and other energy-service providers.

2 "Other" includes public street and highway lighting, other sales to public authorities, sales to railroads and railways, and interdepartmental sales through 2002. Transportation-sector sales reported starting in 2010.

${ }^{3}$ Commercial and industrial facility use of on-site net electricity generation; and electricity sales among adjacent or colocated facilities for which revenue information is not available. 


\section{Table 8.2 - Demand-Side Management}

$\begin{array}{rrrrrrr}\underline{\mathbf{1 9 8 0}} & \underline{\mathbf{1 9 9 0}} & \underline{\mathbf{2 0 0 0}} & \underline{\mathbf{2 0 0 1}} & \underline{\mathbf{2 0 0 2}} & \underline{\mathbf{2 0 0 3}} & \underline{\mathbf{2 0 0 4}} \\ \text { NA } & \text { NA } & 10,027 & 11,928 & 9,516 & 9,323 & 9,260 \\ \text { NA } & \text { NA } & 12,873 & 13,027 & 13,420 & 13,581 & 14,272 \\ \text { NA } & 13,704 & 22,901 & 24,955 & 22,936 & 22,904 & 23,532 \\ \text { NA } & 20,458 & 53,701 & 54,762 & 54,075 & 50,265 & 54,710 \\ \text { NA } & 1,562 & 1,694 & 1,723 & 1,690 & 1,325 & 1,557\end{array}$

Load Management Peak Load Reductions (MW)

Energy Efficiency Peak Load Reductions (MW) ${ }^{2}$

Total Peak Load Reductions (MW)

Energy Savings (Million kWh)

Costs (Million 2004\$)

NA

, 694

1,557

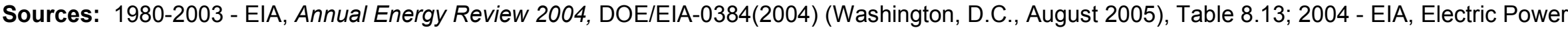
Annual 2004 Tables, (Washington, D.C., December 2005), Table 9.1, 9.2, 9.4, 9.6, and 9.7 http://www.eia.doe.gov/cneaf/electricity/epa/epat9p1.html

Notes:

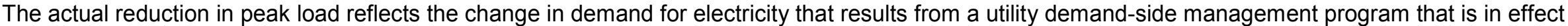

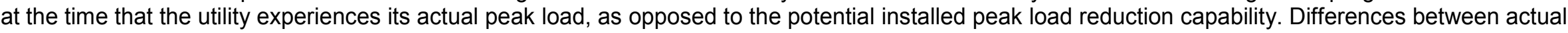
and potential peak reduction result from changes in weather, economic activity, and other variable conditions.

${ }^{1}$ Load management includes programs such as direct load control and interruptible load control; and, beginning in 1997, "other types" of demand-side

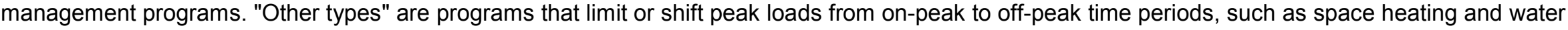
heating storage systems.

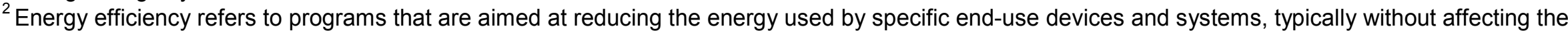
services provided. From 1989 to 1996, energy efficiency includes "other types" of demand-side management programs. Beginning in 1997, these programs are included under load management.

${ }^{3}$ Historical data converted to 2004 dollars using EIA Annual Energy Review 2004, Appendix D. 
Table 8.3 - Electricity Sales, Revenue, and Consumption by Census Division and State, 2004

Census Division and State

New England

Connecticut

Maine

Massachusetts

New Hampshire

Rhode Island

Vermont

Middle Atlantic

New Jersey

New York

Pennsylvania

East North Central

Illinois

Indiana

Michigan

Ohio

Wisconsin

West North Central

lowa

Kansas

Minnesota

Missouri

Nebraska

North Dakota

South Dakota
Average Electricity

Revenue Revenue Consumption

Sales (MWh) $\quad$ (million \$) $(\phi / \mathrm{kWh}) \quad$ (kWh/person)
Census Division and State

$\begin{array}{rrrrl}\mathbf{1 2 5 , 2 4 9} & \mathbf{1 3 , 2 8 4} & \mathbf{1 0 . 6} & \mathbf{8 , 7 9 6} & \text { East South Central } \\ 32,215 & 3,305 & 10.3 & 9,177 & \text { Alabama } \\ 12,368 & 1,198 & 9.7 & 9,359 & \text { Kentucky } \\ \mathbf{5 6 , 1 4 2} & 6,045 & 10.8 & 8,774 & \text { Mississippi } \\ 10,973 & 1,248 & 11.4 & 8,377 & \text { Tennessee } \\ \mathbf{7 , 8 8 8} & 865 & 11.0 & 7,329 & \text { West South Central } \\ 5,664 & 624 & 11.0 & 9,090 & \text { Arkansas } \\ \mathbf{3 6 6 , 1 7 6} & \mathbf{3 7 , 6 7 9} & \mathbf{1 0 . 3} & \mathbf{9 , 0 6 3} & \text { Louisiana } \\ \mathbf{7 7 , 5 9 3} & 7,984 & 10.3 & 8,900 & \text { Oklahoma } \\ 145,082 & 18,209 & 12.6 & 7,535 & \text { Texas } \\ 143,501 & 11,486 & 8.0 & 11,545 & \text { Mountain } \\ \mathbf{5 7 1 , 1 5 1} & \mathbf{3 7 , 9 2 0} & \mathbf{6 . 6} & \mathbf{1 2 , 3 7 4} & \text { Arizona } \\ 139,254 & 9,465 & 6.8 & 10,910 & \text { Colorado } \\ 103,094 & 5,749 & 5.6 & 16,437 & \text { Idaho } \\ 106,606 & 7,401 & 6.9 & 10,533 & \text { Montana } \\ 154,221 & 10,629 & 6.9 & 13,453 & \text { Nevada } \\ \mathbf{6 7 , 9 7 6} & 4,677 & 6.9 & 12,278 & \text { New Mexico } \\ \mathbf{2 6 1 , 0 3 0} & \mathbf{1 6 , 0 9 5} & \mathbf{6 . 2} & \mathbf{1 3 , 1 7 3} & \text { Utah } \\ \mathbf{4 0 , 9 0 3} & 2,619 & 6.4 & 13,789 & \text { Wyoming } \\ 37,127 & 2,364 & 6.4 & 13,527 & \text { Pacific Contiguous } \\ \mathbf{6 3 , 3 4 0} & 3,950 & 6.2 & 12,340 & \text { California } \\ \mathbf{7 4 , 0 5 4} & 4,494 & 6.1 & 12,767 & \text { Oregon } \\ 25,876 & 1,475 & 5.7 & 14,712 & \text { Washington } \\ \mathbf{1 0 , 5 1 6} & 599 & 5.7 & 16,518 & \text { Noncontiguous } \\ \mathbf{9 , 2 1 4} & 594 & 6.4 & 11,875 & \text { Alaska }\end{array}$

Average Electricity

Revenue Revenue Consumption Sales (MWh) (million \$) ( $\quad$ /kWh) (kWh/person)

319,085
86,871
86,521
46,033
99,661
494,966
43,672
79,737
50,942
320,615
237,632
66,933
46,724
21,809
12,957
31,312
19,846
24,512
13,540
378,382
252,764
45,636
79,982
16,520
5,788

$\begin{array}{rrr}\mathbf{1 8 , 6 1 8} & \mathbf{5 . 8} & \mathbf{1 8 , 1 1 4} \\ 5,278 & 6.1 & 19,060 \\ 4,004 & 4.6 & 20,732 \\ 3,221 & 7.0 & 15,759 \\ 6,115 & 6.1 & 16,713 \\ \mathbf{3 6 , 9 5 2} & \mathbf{7 . 5} & \mathbf{1 4 , 6 8 3} \\ 2,475 & 5.7 & 15,714 \\ 5,682 & 7.1 & 17,627 \\ 3,313 & 6.5 & 14,358 \\ 25,482 & 7.9 & 14,025 \\ \mathbf{1 6 , 3 0 6} & \mathbf{6 . 9} & \mathbf{1 1 , 7 1 1} \\ \mathbf{4 , 9 8 5} & 7.4 & 11,270 \\ 3,247 & 6.9 & 10,015 \\ \mathbf{1 , 0 8 5} & 5.0 & 15,260 \\ 830 & 6.4 & 13,848 \\ 2,681 & 8.6 & 12,967 \\ 1,409 & 7.1 & 10,291 \\ 1,395 & 5.7 & 9,925 \\ 674 & 5.0 & 26,585 \\ \mathbf{3 6 , 4 0 7} & \mathbf{9 . 6} & \mathbf{8 , 2 1 5} \\ \mathbf{2 8 , 9 3 5} & 11.4 & 6,996 \\ 2,833 & 6.2 & 12,534 \\ \mathbf{4 , 6 3 8} & 5.8 & 12,720 \\ \mathbf{2 , 3 2 1} & \mathbf{1 4 . 0} & \mathbf{2 , 8 3 2} \\ \mathbf{6 3 6} & 11.0 & \mathbf{1 , 2 7 0}\end{array}$




$\begin{array}{lrrrrrrr}\text { South Atlantic } & \mathbf{7 7 8 , 0 2 6} & \mathbf{5 4 , 8 7 4} & \mathbf{7 . 1} & \mathbf{1 3 , 9 7 3} & \text { Hawaii } & 10,732 & 1,685 \\ \text { Delaware } & 11,761 & 885 & 7.5 & 13,943 & \text { U.S. Total } & \mathbf{3 , 5 4 8 , 2 1 8} & \mathbf{2 7 0 , 4 5 6} \\ \text { District of Columbia } & 11,415 & 852 & 7.5 & 225,943 & & \mathbf{7 . 6} \\ \text { Florida } & 218,584 & 17,835 & 8.2 & 12,287 & \\ \text { Georgia } & 129,466 & 8,525 & 6.6 & 14,270 & \\ \text { Maryland } & 66,892 & 4,785 & 7.2 & 11,944 & \\ \text { North Carolina } & 125,657 & 8,756 & 7.0 & 14,471 & \\ \text { South Carolina } & 79,908 & 4,972 & 6.2 & 18,780 & \\ \text { Virginia } & 105,424 & 6,780 & 6.4 & 13,931 & \\ \text { West Virginia } & 28,919 & 1,483 & 5.1 & 15,917 & \end{array}$

Sources: EIA, Electric Sales and Revenue 2004 Spreadsheets, Data Tables, http://www.eia.doe.gov/cneaf/electricity/esr/esr_sum.html Tables 1b, 1c, 1d, and U.S. Census Bureau, Annual Estimates of the Population for the United States and States, and for Puerto Rico: April 1, 2000 to July 1, 2005 (NST-

EST2004-01) - State Population Estimates 2005, http://www.census.gov/popest/states/tables/NST-EST2005-01.xls

Notes:

Revenue in 2004 dollars.

Includes bundled and unbundled consumers 


\section{Table 9.1 - Price of Fuels Delivered to Electric Generators}

(2004 Dollars per Million Btu) ${ }^{1}$

\begin{tabular}{|c|c|c|c|c|c|c|c|c|c|c|c|c|}
\hline & $\underline{1980}$ & $\underline{1993}$ & $\underline{2000}$ & $\underline{2001}$ & $\underline{2002}$ & $\underline{2003}$ & $\underline{2004}$ & $\underline{2010}$ & $\underline{2015}$ & $\underline{2020}$ & $\underline{2025}$ & $\underline{2030}$ \\
\hline Distillate Fuel & NA & NA & NA & NA & NA & 6.65 & 9.23 & 9.04 & 9.02 & 9.62 & 10.05 & 10.28 \\
\hline Residual Fuel $^{2}$ & NA & 2.88 & 4.48 & 3.87 & 3.44 & 4.40 & 4.29 & 5.70 & 5.72 & 6.02 & 6.43 & 6.73 \\
\hline Natural Gas ${ }^{3}$ & NA & 3.11 & 4.61 & 4.70 & 3.67 & 5.46 & 5.96 & 5.46 & 5.08 & 5.40 & 5.87 & 6.26 \\
\hline Steam Coal ${ }^{4}$ & NA & 1.69 & 1.29 & 1.29 & 1.29 & 1.29 & 1.36 & 1.48 & 1.40 & 1.39 & 1.44 & 1.51 \\
\hline Fossil Fuel Average ${ }^{5}$ & NA & 1.93 & 1.86 & 1.81 & 1.56 & 2.31 & 2.57 & 2.41 & 2.41 & 2.46 & 2.50 & 2.49 \\
\hline
\end{tabular}

Sources: EIA, Annual Energy Outlook 2006, DOE/EIA-0383(2006) (Washington, D.C., February 2006), Table A3; and EIA, Electric Power Annual 2004, DOE/EIA-0348(2004) (Washington, D.C., November 2005), Table 4.5.

Notes:

Includes electricity-only and combined-heat-and-power plants whose primary business is to sell electricity - or electricity and heat - to the public.

Data are for steam-electric plants with a generator nameplate capacity of 50 or more megawatts.

Beginning in 2002, data from the Form EIA-423, "Monthly Cost and Quality of Fuels for Electric Plants Report" for independent power producers and combined-heat-and-power producers are included in this data dissemination. Prior to 2002, these data were not collected; the data for 2001 and previous years include only data collected from electric utilities via the FERC Form 423.

${ }^{1}$ Historical data converted to 2003\$/MMBtu using EIA Annual Energy Review 2003, Appendix D.

${ }^{2}$ 1990-2003 data are for distillate fuel oil (all diesel and No. 1, No. 2, and No. 4 fuel oils), residual fuel oil (No. 5 and No. 6 fuel oils and bunker C fuel oil), jet fuel, kerosene, petroleum coke (converted to liquid petroleum), and waste oil.

${ }^{3}$ Natural gas, including a small amount of supplemental gaseous fuels that cannot be identified separately.

${ }^{4}$ Anthracite, bituminous coal, subbituminous coal, lignite, waste coal, and synthetic coal.

${ }^{5}$ Weighted average price.

$\mathrm{NA}=$ not available 


\section{Table 9.2 - Electricity Retail Sales}

(Billion Kilowatthours)

\begin{tabular}{lrrrrrrr|rrrrrr} 
& $\mathbf{1 9 8 0}$ & $\underline{\mathbf{1 9 9 0}}$ & $\underline{\mathbf{2 0 0 0}}$ & $\underline{\mathbf{2 0 0 1}}$ & $\underline{\underline{\mathbf{2 0 0 2}}}$ & $\underline{\underline{\mathbf{2 0 0 3}}}$ & $\underline{\underline{\mathbf{2 0 0 4}}}$ & $\underline{\underline{\mathbf{2 0 1 0}}}$ & $\underline{\underline{\mathbf{2 0 1 5}}}$ & $\underline{\underline{\mathbf{2 0 2 0}}}$ & $\underline{\underline{\mathbf{2 0 2 5}}}$ & $\underline{\underline{\mathbf{2 0 3 0}}}$ \\
Retail Sales & 1 & & & & & & & & & & & & \\
Residential & 717 & 924 & 1,192 & 1,203 & 1,267 & 1,273 & 1,293 & 1,461 & 1,576 & 1,691 & 1,787 & 1,897 \\
Commercial $^{2}$ & 559 & 838 & 1,159 & 1,197 & 1,218 & 1,200 & 1,229 & 1,430 & 1,592 & 1,762 & 1,944 & 2,151 \\
Industrial $^{3}$ & 815 & 946 & 1,064 & 964 & 972 & 1,008 & 1,021 & 1,060 & 1,103 & 1,147 & 1,195 & 1,262 \\
Transportation $^{4}$ & 3 & 5 & 5 & 5 & 6 & 7 & 8 & 26 & 28 & 29 & 30 & 31 \\
Total $^{5}$ & 2,094 & 2,713 & 3,421 & 3,370 & 3,463 & 3,488 & 3,551 & 4,155 & 4,491 & 4,844 & 5,208 & 5,619
\end{tabular}

Sources: EIA, Annual Energy Outlook 2006, DOE/EIA-0383 (2006), (Washington, D.C., February 2006), Table A8; and EIA, Annual Energy Review 2004, DOE/EIA-0384(2004) (Washington, D.C., September 2005), Table 8.9.

\section{Notes:}

${ }^{1}$ Electricity retail sales to ultimate customers reported by electric utilities and, beginning in 1996, other energy-service providers.

${ }^{2}$ Commercial sector, including public street and highway lighting, interdepartmental sales, and other sales to public authorities.

${ }^{3}$ Industrial sector. Through 2002, excludes agriculture and irrigation; beginning in 2003, includes agriculture and irrigation.

${ }^{4}$ Transportation sector, including sales to railroads and railways.

${ }^{5}$ The sum of "Residential," "Commercial," "Industrial," and "Transportation." 


\section{Table 9.3 - Prices of Electricity Sold}

(2003 cents per Kilowatthour) ${ }^{1}$

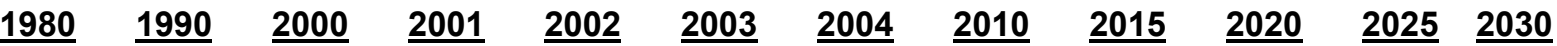

Price by End-Use Sector ${ }^{2}$

Residential

$\begin{array}{rrrrrrrrrrrr}10.8 & 10.4 & 8.9 & 9.1 & 8.8 & 8.9 & 8.9 & 8.5 & 8.3 & 8.3 & 8.4 & 8.5 \\ 11.0 & 9.7 & 8.0 & 8.4 & 8.2 & 8.1 & 8.2 & 7.6 & 7.4 & 7.5 & 7.7 & 7.8 \\ 7.4 & 6.3 & 5.0 & 5.3 & 5.1 & 5.2 & 5.1 & 5.3 & 5.1 & 5.2 & 5.4 & 5.4 \\ 9.6 & 8.5 & 7.1 & 7.4 & 7.0 & 7.7 & 6.5 & 7.1 & 6.9 & 7.0 & 7.1 & 7.2 \\ 9.4 & 8.7 & 7.4 & 7.7 & 7.5 & 7.6 & 7.6 & 7.3 & 7.1 & 7.2 & 7.4 & 7.5\end{array}$

Price by Service Category ${ }^{2}$

Generation

$\begin{array}{llllllllllll}\text { NA } & \text { NA } & \text { NA } & \text { NA } & \text { NA } & 5.0 & 5.8 & 4.7 & 4.6 & 4.8 & 5.0 & 5.1 \\ \text { NA } & \text { NA } & \text { NA } & \text { NA } & \text { NA } & 0.5 & 0.5 & 0.6 & 0.6 & 0.7 & 0.7 & 0.7 \\ \text { NA } & \text { NA } & \text { NA } & \text { NA } & \text { NA } & 2.1 & 2.0 & 2.0 & 1.9 & 1.9 & 1.8 & 1.8\end{array}$

Distribution

Sources: EIA, Annual Energy Outlook 2006, DOE/EIA-0383 (2006), (Washington, D.C., February 2006), Table A8; and EIA, Annual Energy Review 2004, DOE/EIA-0384(2004) (Washington, D.C., August 2005), Table 8.10.

\section{Notes:}

For 1980, data are for selected Class A utilities whose electric operating revenues were $\$ 100$ million or more during the previous year.

For 1990, data are for a census of electric utilities. For 2000 onward, data also include energy-service providers selling to retail customers ${ }^{1}$ Historical data real prices expressed in chained (2004) dollars, calculated by using gross domestic product implicit price deflators using EIA Annual Energy Review 2004 Appendix D.

${ }^{2}$ Prices represent average revenue per kilowatthour.

${ }^{3}$ Public street and highway lighting, other sales to public authorities, sales to railroads and railways and interdepartmental sales.

$\mathrm{NA}=$ not available 


\section{Table 9.4 - Revenue from Electric-Utility Retail Sales by Sector}

(Millions of 2004 Dollars)

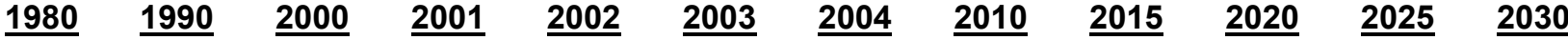

\begin{tabular}{|c|c|c|c|c|c|c|c|c|c|c|c|c|}
\hline esid & 77,598 & 0 & 1 & 9 & 1 & 113 & & & 13 & & & \\
\hline om & 1,537 & 1,624 & 93,235 & 100,369 & 99,536 & 97,760 & 100,369 & 08,680 & 117,808 & 132,150 & 9,688 & 78 \\
\hline ial & 60,399 & 9,455 & 53,448 & 51,368 & 49,331 & 52,803 & 52,173 & 56,180 & 56,259 & 59,658 & 64,533 & 68,16 \\
\hline Transportation/Other & & 289 & 424 & 355 & 372 & 420 & 542 & 519 & 1,846 & 1,932 & 2,030 & 2,13 \\
\hline II Sectors ${ }^{2}$ & $\begin{array}{l}91,1 \\
\text {. }\end{array}$ & 419 & 19 & 0,731 & 9,589 & 34,29 & 68,811 & 3,315 & 18,86 & 48,74 & 385,39 & 21,4 \\
\hline
\end{tabular}

Sources: Calculated from EIA, Annual Energy Outlook 2006, DOE/EIA-0383 (2006), (Washington, D.C., February 2006), Table A8; EIA, Annual Energy Review 2004, DOE/EIA-0384 (2004) (Washington, D.C., August 2005), Tables 8.9 and 8.10.

\section{Notes:}

1 "Other" includes public street and highway lighting, other sales to public authorities, sales to railroads and railways, and interdepartmental sales through 2003.Transportation-sector revenue reported starting in 2010.

${ }^{2}$ For 1980 , data are for selected Class A utilities whose electric operating revenues were $\$ 100$ million or more during the previous year. For 1990, data are for a census of electric utilities. For 2000 onward, data also include energy-service providers selling to retail customers 
Table 9.5 - Revenue from Sales to Ultimate Consumers by Sector, Census Division, and State, 2004

(Millions of 2004 Dollars)

\begin{tabular}{|c|c|c|c|c|c|c|c|c|c|c|c|}
\hline $\begin{array}{l}\text { Census Division/ } \\
\text { State }\end{array}$ & $\begin{array}{l}\text { Residen- } \\
\text { tial }\end{array}$ & $\begin{array}{l}\text { Commer- } \\
\text { cial }\end{array}$ & Industrial & Other $^{1}$ & All Sectors ${ }^{2}$ & $\begin{array}{l}\text { Census Division/ } \\
\text { State }\end{array}$ & $\begin{array}{l}\text { Residen- } \\
\text { tial }\end{array}$ & $\begin{array}{l}\text { ommer- } \\
\text { cial }\end{array}$ & Industrial & Other $^{1}$ & All Sectors $^{2}$ \\
\hline New England & 5,560 & 5,696 & 1,995 & 33 & 13,284 & East South Central & 7,934 & 5,551 & 5,134 & 0 & 18,618 \\
\hline Connecticut & 1,537 & 1,332 & 423 & 14 & 3,305 & Alabama & 2,295 & 1,506 & 1,477 & 0 & 5,278 \\
\hline Maine & 527 & 428 & 244 & - & 1,198 & Kentucky & 1,538 & 1,034 & 1,432 & 0 & 4,004 \\
\hline Massachusetts & 2,323 & 2,858 & 844 & 19 & 6,045 & Mississippi & 1,444 & 1,019 & 759 & 0 & 3,221 \\
\hline New Hampshire & 535 & 480 & 233 & - & 1,248 & Tennessee & 2,657 & 1,992 & 1,466 & 0 & 6,115 \\
\hline Rhode Island & 366 & 373 & 126 & - & 865 & West South Central & 16,701 & 11,299 & 8,945 & 7 & 36,952 \\
\hline Vermont & 273 & 226 & 126 & - & 624 & Arkansas & 1,150 & 605 & 720 & 0 & 2,475 \\
\hline Middle Atlantic & 14,890 & 17,221 & 5,266 & 302 & 37,679 & Louisiana & 2,324 & 1,710 & 1,646 & 1 & 5,682 \\
\hline New Jersey & 3,148 & 3,793 & 1,012 & 32 & 7,984 & Oklahoma & 1,520 & 1,116 & 677 & 0 & 3,313 \\
\hline New York & 6,890 & 9,654 & 1,455 & 210 & 18,209 & Texas & 11,707 & 7,867 & 5,902 & 6 & 25,482 \\
\hline Pennsylvania & 4,853 & 3,774 & 2,799 & 60 & 11,486 & Mountain & 6,732 & 5,975 & 3,596 & 3 & 16,306 \\
\hline East North Central & 14,847 & 12,855 & 10,187 & 32 & 37,920 & Arizona & 2,447 & 1,901 & 637 & 0 & 4,985 \\
\hline Illinois & 3,638 & 3,570 & 2,232 & 25 & 9,465 & Colorado & 1,307 & 1,343 & 596 & 1 & 3,247 \\
\hline Indiana & 2,277 & 1,448 & 2,022 & 1 & 5,749 & Idaho & 446 & 294 & 344 & 0 & 1,085 \\
\hline Michigan & 2,759 & 2,925 & 1,717 & 0 & 7,401 & Montana & 319 & 321 & 190 & 0 & 830 \\
\hline Ohio & 4,251 & 3,510 & 2,864 & 5 & 10,629 & Nevada & 1,034 & 752 & 895 & 0 & 2,681 \\
\hline Wisconsin & 1,922 & 1,401 & 1,353 & - & 4,677 & New Mexico & 488 & 609 & 312 & 0 & 1,409 \\
\hline West North Central & 7,044 & 5,505 & 3,544 & 1 & 16,095 & Utah & 528 & 551 & 314 & 2 & 1,395 \\
\hline lowa & 1,132 & 731 & 756 & - & 2,619 & Wyoming & 163 & 203 & 308 & 0 & 674 \\
\hline Kansas & 962 & 893 & 510 & - & 2,364 & Pacific Contiguous & 13,990 & 16,307 & 6,063 & 46 & 36,407 \\
\hline Minnesota & 1,624 & 1,287 & 1,038 & 1 & 3,950 & California & 10,628 & 13,554 & 4,710 & 43 & 28,935 \\
\hline Missouri & 2,185 & 1,648 & 661 & 0 & 4,494 & Oregon & 1,293 & 1,010 & 529 & 1 & 2,833 \\
\hline Nebraska & 610 & 497 & 369 & - & 1,475 & Washington & 2,069 & 1,742 & 825 & 3 & 4,638 \\
\hline
\end{tabular}




\begin{tabular}{|c|c|c|c|c|c|c|c|c|c|c|c|}
\hline North Dakota & 249 & 225 & 124 & - & 599 & $\begin{array}{l}\text { Pacific } \\
\text { Noncontiguous }\end{array}$ & 828 & 874 & 619 & 0 & 2,321 \\
\hline South Dakota & 283 & 224 & 87 & - & 594 & Alaska & 256 & 286 & 94 & 0 & 636 \\
\hline South Atlantic & 27,510 & 18,973 & 8,310 & 80 & 54,874 & Hawaii & 571 & 588 & 526 & 0 & 1,685 \\
\hline Delaware & 378 & 300 & 207 & - & 885 & U.S. Total & 116,037 & 100,255 & 53,661 & 504 & 270,456 \\
\hline District of Columbia & 147 & 670 & 13 & 22 & 852 & & & & & & \\
\hline Florida & 10,086 & 6,601 & 1,140 & 7 & 17,835 & & & & & & \\
\hline Georgia & 4,016 & 2,912 & 1,587 & 9 & 8,525 & & & & & & \\
\hline Maryland & 2,181 & 1,304 & 1,269 & 31 & 4,785 & & & & & & \\
\hline North Carolina & 4,369 & 2,871 & 1,516 & - & 8,756 & & & & & & \\
\hline South Carolina & 2,267 & 1,390 & 1,315 & - & 4,972 & & & & & & \\
\hline Virginia & 3,397 & 2,530 & 843 & 10 & 6,780 & & & & & & \\
\hline West Virginia & 670 & 394 & 419 & 0 & 1,483 & & & & & & \\
\hline
\end{tabular}

Source: EIA, Electric Sales and Revenue 2004 Spreadsheets, Data Tables, http://www.eia.doe.gov/cneaf/electricity/esr/esr_tabs.html, Table 1c.

\section{Notes:}

${ }^{1}$ Includes sales for public street and highway lighting, to public authorities, railroads and railways, and interdepartmental sales.

${ }^{2}$ Includes bundled and unbundled consumers. 


\section{Table 9.6 - Production, Operation, and Maintenance Expenses for Major U.S.}

\section{Investor-Owned and Publicly Owned Utilities}

(Million of Nominal Dollars)

Production Expenses
Cost of Fuel
Purchased Power
Other Production Expenses
Total Production Expenses

\section{$\underline{1990}$}

Investor-Owned Utilities

$1995 \quad 2000 \quad 2002 \quad 2003$

$\begin{array}{llllll}32,635 & 29,122 & 32,555 & 24,132 & 26,476 & 28,678\end{array}$

$\begin{array}{llllll}20,341 & 29,981 & 61,969 & 58,828 & 62,173 & 67,354\end{array}$

$\begin{array}{lllllll}9,526 & 9,880 & 12,828 & 7,688 & 7,532 & 8,256\end{array}$

$\begin{array}{llllll}62,502 & 68,983 & 107,352 & 90,649 & 96,181 & 104,288\end{array}$

\section{Operation and Maintenance Expenses}

Transmission Expenses

Distribution Expenses

Customer Accounts Expenses

Customer Service and Information Expenses

Sales Expenses

Administrative and General Expenses

Total Electric Operation and Maintenance Expenses

$\begin{array}{rrr}1,130 & 1,425 & 2,6 \\ 2,444 & 2,561 & 3,1 \\ 3,247 & 3,613 & 4,24 \\ 1,181 & 1,922 & 1,839 \\ 212 & 348 & \\ 10,371 & 13,028 & 13,0 \\ 18,585 & 22,897 & 25,3 \\ & \\ 48(2004) & \text { (Washington, } \\ \text { December 2002), Table } \\ \text { ber 1995), Table } 8 \text { and Tab } \\ \text { ber 2000), Table 10 and } \\ \text { Ter 2001), Table 10 and }\end{array}$

Source: EIA, Electric Power Annual 2004, DOE/EIA-0348(2004) (Washington, D.C., November 2005), Tables 8.1, 8.3, and 8.4; and EIA, Electric Power Annual 2001, DOE/EIA-0348(2001) (Washington, D.C., December 2002), Table 8.1; EIA, Financial Statistics of Major US Publicly Owned Electric Utilities 1994, DOE/EIA-0437(94)/2 (Washington, D.C., December 1995), Table 8 and Table 17; EIA, Financial Statistics of Major US Publicly Owned Electric Utilities 1999, DOE/EIA-0437(99)/2 (Washington, D.C., November 2000), Table 10 and Table 21; EIA, Financial Statistics of Major US Publicly Owned Electric Utilities 2000, DOE/EIA-0437(00)/2 (Washington, D.C., November 2001), Table 10 and Table 21.; EIA, Public Electric Utility Database (Form EIA-412) 2002 and 2003.

\section{Notes:}

${ }_{2}^{1}$ Publicly Owned Utilities include generator and nongenerator electric utilities.

${ }^{2}$ Totals may not equal sum of components, because of independent rounding.

${ }^{3}$ Collection of Form EIA-412 has been suspended, data for 2004 not available. 



\section{Table 9.6a - Operation and Maintenance Expenses for Major}

\section{U.S. Investor-Owned Electric Utilities}

(Million of Nominal Dollars, unless otherwise indicated)

$\begin{array}{lrrrrrr} & \underline{\mathbf{1 9 9 0}} & \underline{\mathbf{1 9 9 5}} & \underline{\mathbf{2 0 0 0}} & \underline{\mathbf{2 0 0 2}} & \underline{\mathbf{2 0 0 3}} & \underline{\underline{\mathbf{2 0 0 4}}} \\ \text { Utility Operating Expenses } & 142,471 & 165,321 & 210,324 & 188,745 & 197,459 & 207,161 \\ \text { Electric Utility } & 127,901 & 150,599 & 191,329 & 171,291 & 175,473 & 182,337 \\ \text { Operation } & 81,086 & 91,881 & 132,662 & 116,374 & 122,723 & 131,962 \\ \text { Production } & 62,501 & 68,983 & 107,352 & 90,649 & 96,181 & 104,287 \\ \text { Cost of Fuel } & 32,635 & 29,122 & 32,555 & 24,132 & 26,476 & 28,678 \\ \text { Purchased Power } & 20,341 & 29,981 & 61,969 & 58,828 & 62,173 & 67,354 \\ \text { Other } & 9,526 & 9,880 & 12,828 & 7,688 & 7,532 & 8,256 \\ \text { Transmission } & 1,130 & 1,425 & 2,699 & 3,494 & 3,585 & 4,519 \\ \text { Distribution } & 2,444 & 2,561 & 3,115 & 3,113 & 3,185 & 3,301 \\ \text { Customer Accounts } & 3,247 & 3,613 & 4,246 & 4,165 & 4,180 & 4,087 \\ \text { Customer Service } & 1,181 & 1,922 & 1,839 & 1,821 & 1,893 & 2,012 \\ \text { Sales } & 212 & 348 & 403 & 261 & 234 & 238 \\ \text { Administrative and General } & 10,371 & 13,028 & 13,009 & 12,872 & 13,466 & 13,519 \\ \text { Maintenance } & 11,779 & 11,767 & 12,185 & 10,843 & 11,141 & 11,774 \\ \text { Depreciation } & 14,889 & 19,885 & 22,761 & 17,319 & 16,962 & 16,373 \\ \text { Taxes and Other } & 20,146 & 27,065 & 23,721 & 26,755 & 24,648 & 22,228 \\ \text { Other Utility } & 14,571 & 14,722 & 18,995 & 17,454 & 21,986 & 24,823\end{array}$

\section{Operation (Mills per}

Kilowatthour) $^{1}$

Nuclear

10.04

9.43

8.41

8.54

8.86

8.3

Fossil Steam

2.21

2.38

2.31

2.54

2.50

2.68

Hydroelectric and Pumped

Storage

3.35

3.69

4.74

5.07

4.50

5.05

Gas Turbine and Small Scale ${ }^{2}$

8.76

3.57

4.57

2.72

2.76

2.73

Maintenance (Mills per

Kilowatthour) ${ }^{1}$

Nuclear

5.68

5.21

4.93

5.04

5.23

5.38

Fossil Steam

2.97

2.65

$2.45 \quad 2.68$

2.73

2.96

Hydroelectric and Pumped

Storage

2.58

2.19

2.99

3.58

3.01

3.64

Gas Turbine and Small Scale ${ }^{2}$

12.23

4.28

$3.50 \quad 2.38$

2.26

2.16

Source: EIA, Electric Power Annual 2004, DOE/EIA-0348(2004) (Washington, D.C., November 2005), Tables 8.1 and 8.2; and EIA, Electric Power Annual 2001, Tables 8.1 and 8.2.

Notes:

${ }^{1}$ Operation and maintenance expenses are averages, weighed by net generation.

${ }^{2}$ Includes gas turbine, internal combustion, photovoltaic, and wind plants. 


\section{Table 9.6b - Operation and Maintenance Expenses for Major U.S. Publicly Owned Generator and Nongenerator Electric Utilities \\ (Million of Nominal Dollars, except employees)}

\author{
Production Expenses \\ Steam Power Generation \\ Nuclear Power Generation \\ Hydraulic Power Generation \\ Other Power Generation \\ Purchased Power \\ Other Production Expenses \\ Total Production Expenses ${ }^{1}$
}

\section{Operation and Maintenance Expenses}

Transmission Expenses

Distribution Expenses

Customer Accounts Expenses

Customer Service and Information Expenses

Sales Expenses

Administrative and General Expenses

Total Electric Operation and Maintenance Expenses

Total Production and Operation and Maintenance Expenses

\section{Fuel Expenses in Operation}

Steam Power Generation

Nuclear Power Generation

Other Power Generation

Total Electric Department Employees ${ }^{2}$

$\begin{array}{rrrrr}\underline{\mathbf{1 9 9 0}} & \underline{\mathbf{1 9 9 5}} & \underline{\mathbf{2 0 0 0}} & \underline{\mathbf{2 0 0 2}} & \underline{\mathbf{2 0 0 3}} \\ & & & & \\ 3,742 & 3,895 & 5,420 & 6,558 & 7,539 \\ 1,133 & 1,277 & 1,347 & 1,646 & 1,739 \\ 205 & 261 & 332 & 746 & 785 \\ 196 & 231 & 603 & 1,144 & 1,100 \\ 10,542 & 11,988 & 16,481 & 24,446 & 26,078 \\ 155 & 212 & 225 & 1,647 & 1,285 \\ 15,973 & 17,863 & 24,398 & 36,188 & 38,526\end{array}$

$\begin{array}{rrrrr}604 & 663 & 845 & 951 & 977 \\ 950 & 630 & 854 & 1,000 & 1,044 \\ 375 & 448 & 662 & 700 & 754 \\ 75 & 120 & 233 & 354 & 311 \\ 29 & 30 & 82 & 84 & 95 \\ 1,619 & 2,127 & 2,097 & 2,594 & 2,742 \\ 3,653 & 4,018 & 4,772 & 5,683 & 5,923 \\ 19,626 & 22,651 & 30,100 & 44,813 & 47,165\end{array}$

$\begin{array}{rrrrr}2,395 & 2,163 & 4,150 & 4,818 & 5,624 \\ 242 & 222 & 316 & 433 & 398 \\ 113 & 101 & 373 & 754 & 771 \\ & & & & \\ \text { N/A } & 73,172 & 71,353 & 93,520 & 92,752\end{array}$

Source: EIA, Financial Statistics of Major US Publicly Owned Electric Utilities 1994, DOE/EIA-0437(94)/2 (Washington, D.C., December 1995), Table 8 and Table 17; EIA, Financial Statistics of Major U.S. Publicly Owned Electric Utilities 1999, DOE/EIA-0437(99)/2 (Washington, D.C., November 2000), Table 10 and Table 21; EIA, Financial Statistics of Major U.S. Publicly Owned Electric Utilities 2000, DOE/EIA-0437(00)/2 (Washington, D.C., November 2001), Table 10 and Table 21; EIA, Public Electric Utility Database (Form EIA-412) 2002 and 2003; EIA, Electric Power Annual 2003, DOE/EIA-0348(2003) (Washington, D.C., December 2004), Tables 8.3 and 8.4

Notes: EIA suspended collection of this dataset in 2004.

${ }^{1}$ Totals may not equal sum of components, because of independent rounding.

${ }^{2}$ Number of employees was not submitted by some publicly owned electric utilities, because the number of electric utility employees could not be separated from the other municipal employees, or the electric utility outsourced much of the work.

$N A=$ not available 


\section{Table 9.7 - Environmental Compliance Equipment Costs}

(Nominal Dollars)

Average Flue Gas Desulfurization Costs

$\begin{array}{lllllll}1990 & 1995 & 2000 & 2001 & \underline{2002} & \underline{2003} & \underline{2004}\end{array}$

at Utilities

Average Operation \& Maintenance Costs

(mills/kWh)

Average Installed Costs $(\$ / \mathrm{kW})$

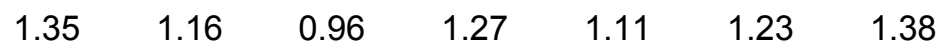

$\begin{array}{lllllll}118 & 126 & 124 & 131 & 124 & 124 & 145\end{array}$

Source: Electric Power Annual 2004, Table 5.3., DOE/EIA-0348(04) (November 2005). EIA, Electric Power Annual 2001, DOE/EIA-0348(01) (March 2003), Table 5.3.

Notes:

Includes plants under the Clean Air Act that were monitored by the Environmental Protection Agency, even if sold to an unregulated entity.

These data are for plants with a fossil-fueled, steam-electric capacity of 100 megawatts or more. 
Table 10.1 - Consumer Price Estimates for Energy Purchases

(2004 Dollars, per Million Btu) ${ }^{1}$

\begin{tabular}{|c|c|c|c|c|c|c|c|c|c|c|}
\hline & 1970 & 1980 & 1990 & $\underline{2000}$ & $\underline{2005}$ & $\underline{2010}$ & $\underline{2015}$ & $\underline{2020}$ & $\underline{2025}$ & $\underline{2030}$ \\
\hline Coal & 1.49 & 2.92 & 1.98 & 1.34 & 1.52 & 1.51 & 1.43 & 1.42 & 1.46 & 1.53 \\
\hline Natural Gas & 2.32 & 5.73 & 5.07 & 6.08 & 9.60 & 7.19 & 6.60 & 6.93 & 7.47 & 7.98 \\
\hline Distillate Fuel & 4.56 & 13.42 & 10.19 & 10.67 & 15.28 & 13.30 & 13.72 & 14.07 & 14.52 & 15.04 \\
\hline Jet Fuel & 2.87 & 12.74 & 7.54 & 7.14 & 12.64 & 9.67 & 9.87 & 10.49 & 10.92 & 11.53 \\
\hline Liquified Petroleum Gases & 5.74 & 11.30 & 8.97 & 11.03 & 18.04 & 13.39 & 13.19 & 14.38 & 15.66 & 16.90 \\
\hline Motor Gasoline & 11.20 & 19.71 & 12.10 & 13.00 & 18.60 & 16.52 & 16.34 & 17.02 & 17.49 & 17.92 \\
\hline Residual Fuel & 1.65 & 7.77 & 4.21 & 4.68 & 6.79 & 6.07 & 6.03 & 6.31 & 6.75 & 7.12 \\
\hline Other $^{2}$ & 5.42 & 14.10 & 7.72 & 7.54 & NA & NA & NA & NA & NA & NA \\
\hline Petroleum Total & 6.76 & 14.82 & 9.91 & 10.73 & 15.28 & 13.30 & 13.72 & 14.07 & 14.52 & 15.04 \\
\hline Nuclear Fuel & 0.71 & 0.86 & 0.89 & 0.50 & N/A & $N / A$ & $N / A$ & N/A & N/A & $\mathrm{N} / \mathrm{A}$ \\
\hline Wood and Waste & 5.07 & 4.53 & 1.72 & 1.73 & $\mathrm{~N} / \mathrm{A}$ & $\mathrm{N} / \mathrm{A}$ & $\mathrm{N} / \mathrm{A}$ & $\mathrm{N} / \mathrm{A}$ & $\mathrm{N} / \mathrm{A}$ & $\mathrm{N} / \mathrm{A}$ \\
\hline Primary Energy Total ${ }^{3}$ & 4.25 & 9.15 & 5.90 & 6.18 & 13.61 & 11.52 & 11.40 & 11.89 & 12.35 & 12.86 \\
\hline Electric Utility Fuel & 1.26 & 3.52 & 1.95 & 1.78 & NA & NA & NA & NA & NA & NA \\
\hline Electricity Purchased by End Users & 19.58 & 27.94 & 25.64 & 21.69 & 24.44 & 21.43 & 20.87 & 21.23 & 21.69 & 22.00 \\
\hline \multirow[t]{2}{*}{ Total Energy ${ }^{3}$} & 6.49 & 13.80 & 10.94 & 11.18 & 15.57 & 13.32 & 13.16 & 13.66 & 14.14 & 14.64 \\
\hline & 1.49 & 2.92 & 1.98 & 1.34 & 1.52 & 1.51 & 1.43 & 1.42 & 1.46 & 1.53 \\
\hline
\end{tabular}

Sources: EIA, Annual Energy Outlook 2006, DOE/EIA-0383 (2006), (Washington, D.C., February 2006), Table A3; and EIA, Annual Energy Review 2004, DOE/EIA-0384 (2004) (Washington, D.C., August 2005), Table 3.3.

Notes:

${ }^{1}$ Historical data converted to 2004\$/MMBtu using GDP deflators from EIA, Annual Energy Review 2004, DOE/EIA-0384(2004) (Washington, D.C., September 2005), Table D.1.

${ }^{2}$ Consumption-weighted average price for asphalt and road oil, aviation gasoline, kerosene, lubricants, petrochemical feedstocks, petroleum coke, special naphthas, waxes, and miscellaneous petroleum products.

${ }^{3}$ The "Primary Energy Total" and "Total Energy" prices include consumption-weighted average prices for coal coke imports and coal coke exports that are not shown in the other columns.

$\mathrm{NA}=$ not available 


\section{Table 10.2 - Economy-Wide Indicators}

(Billions of 2000 Chain Weighted Dollars, unless otherwise noted)

\begin{tabular}{|c|c|c|c|c|c|c|c|c|c|}
\hline & 1980 & 1990 & $\underline{2000}$ & 2004 & $\underline{2010}$ & $\underline{2015}$ & 2020 & $\underline{2025}$ & $\underline{2030}$ \\
\hline GDP Chain Type Price Index $(2000=1.000)$ & 0.541 & 0.816 & 1.000 & 1.091 & 1.235 & 1.398 & 1.597 & 1.818 & 2.048 \\
\hline Real Gross Domestic Product & 5,162 & 7,113 & 9,817 & 10,756 & 13,043 & 15,082 & 17,541 & 20,123 & 23,112 \\
\hline Real Consumption & 3,374 & 4,770 & 6,739 & 7,589 & 9,128 & 10,373 & 11,916 & 13,555 & 15,352 \\
\hline Real Investment & 645 & 895 & 1,736 & 1,810 & 2,259 & 2,713 & 3,293 & 4,025 & 4,985 \\
\hline Real Government Spending & 1,115 & 1,530 & 1,722 & 1,952 & 2,150 & 2,296 & 2,464 & 2,631 & 2,838 \\
\hline Real Exports & 324 & 553 & 1,096 & 1,118 & 1,831 & 2,671 & 3,776 & 5,083 & 6,833 \\
\hline Real Imports & 311 & 607 & 1,476 & 1,719 & 2,295 & 2,857 & 3,659 & 4,734 & 6,156 \\
\hline Real Disposable Personal Income & 3,858 & 5,324 & 7,194 & 8,004 & 9,622 & 11,058 & 13,057 & 15,182 & 17,562 \\
\hline Consumer Price Index $(2002=1.000)$ & 0.824 & 1.307 & 1.722 & 1.889 & 2.153 & 2.464 & 2.862 & 3.310 & 3.783 \\
\hline Unemployment Rate (percent) & 7.1 & 5.6 & 4.0 & 5.5 & 4.7 & 4.6 & 4.4 & 4.8 & 4.9 \\
\hline Housing Starts (millions) & 1.3 & 1.2 & 1.6 & 2.1 & 2.0 & 2.0 & 1.9 & 1.8 & 1.8 \\
\hline \multicolumn{10}{|l|}{ Gross Output } \\
\hline Total Industrial & & & & 5,643 & 6,355 & 7,036 & 7,778 & 8,589 & 9,578 \\
\hline Non-Manufacturing & & & & 1,439 & 1,572 & 1,689 & 1,808 & 1,926 & 2,069 \\
\hline Manufacturing & & & & 4,204 & 4,783 & 5,347 & 5,969 & 6,664 & 7,509 \\
\hline Energy-Intensive Manufacturing & & & & 1,161 & 1,265 & 1,350 & 1,441 & 1,529 & 1,627 \\
\hline Non-Energy-Intensive Manufacturing & & & & 3,044 & 3,518 & 3,997 & 4,528 & 5,135 & 5,882 \\
\hline Population (all ages, millions) & 226.5 & 248.8 & 281.4 & 294.1 & 310.1 & 323.5 & 337.0 & 350.6 & 364.8 \\
\hline Employment Non-Agriculture (millions) & 95.9 & 115.6 & 134.4 & 131.4 & 142.1 & 147.6 & 156.2 & 164.2 & 173.6 \\
\hline Employment Manufacturing (millions) & 20.4 & 19.2 & 17.5 & 14.3 & 14.0 & 13.5 & 13.3 & 12.9 & 12.6 \\
\hline
\end{tabular}

Sources: EIA, Annual Energy Outlook 2006, DOE/EIA-0383(2006) (Washington, D.C., February 2006), Table A19; EIA, Annual Energy Review 2003, DOE/EIA-0384(2003) (Washington, D.C., October 2004), Table D1, Bureau Of Economic Analysis, National Income and Products Accounts Tables (NIPA), Tables 1.1.4, 1.1.6, 2.1, and 6.4 B-D, http://www.bea.doc.gov/bea/dn/nipaweb/NIPATablelndex.asp, Department of Labor, Bureau of Labor Statistics, Current Population Survey, Current Population Survey, Household Data Annual Averages,

http://www.bls.gov/cps/cpsa2003.pdf, National Association of Home Builders,

http://www.nahb.org/generic.aspx?sectionID=130\&genericContentID=554. 


\section{Table 10.3 - Composite Statements of Income for Major U.S. Publicly Owned Generator}

and Investor-Owned Electric Utilities, 2004

(Million 2004 Dollars)

$\begin{array}{lll}\frac{\text { Investor-Owned }}{\text { Electric Utilities }} & \text { Publicly Owned Generator } & \text { Cooperative Borrower } \\ \text { Electric Utilities } & \text { 1,2 } & \text { Owned Electric Utilities }\end{array}$

$\begin{array}{lrrr}\text { Operating Revenue - Electric } & 213,539 & 46,360 & 30,650 \\ \text { Operating Expenses - Electric } & 182,337 & 41,118 & 27,828 \\ \text { Operation Including Fuel } & 131,962 & 32,737 & 25,420 \\ \text { Production } & 104,287 & 26,813 & 20,752 \\ \text { Transmission } & 4,519 & 977 & 665 \\ \text { Distribution } & 3,301 & 1,044 & 1,860 \\ \text { Customer Accounts } & 4,180 & 754 & 595 \\ \text { Customer Service } & 2,012 & 311 & 141 \\ \text { Sales } & 238 & 95 & 80 \\ \text { Administrative and General } & 13,519 & 1,327 \\ \text { Maintenance } & 11,774 & 2,742 & \mathrm{NA} \\ \text { Depreciation and Amortization } & 16,373 & 2,504 & 2,182 \\ \text { Taxes and Tax Equivalents } & 22,228 & 4,555 & 226 \\ \text { Net Electric Operating Income } & 33,158 & 1,323 & 2,822\end{array}$

Source: EIA, Electric Power Annual 2004, DOE/EIA-0348(2003), (Washington, D.C., November 2005), Tables 8.1, 8.3, 8.4, and 8.6. Note:

${ }_{1}^{1}$ The data represent those utilities meeting a threshold of 150 million kilowatthours of customer sales or resale for the two previous years.

${ }^{2}$ Values for 2003. In 2004, Form EIA-412 has been suspended until further notice. Includes utilities with and without generating facilities.

$\mathrm{NA}=$ not available 
Table 11.1 - Emissions from Electricity Generators

(Thousand short tons of gas)

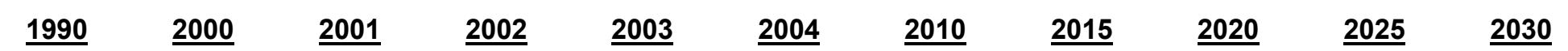

Coal Fired

Carbon Dioxide

\begin{tabular}{|c|c|c|c|c|c|c|c|c|c|c|}
\hline $1,674,521$ & $2,090,644$ & $2,034,867$ & $2,043,795$ & $2,086,014$ & $2,087,667$ & $2,367,580$ & $2,412,270$ & $2,583,310$ & $2,843,355$ & $3,170,875$ \\
\hline 15,220 & 10,623 & 10,004 & 9,732 & NA & NA & NA & NA & NA & NA & NA \\
\hline 5,642 & 4,563 & 4,208 & 4,094 & NA & NA & NA & NA & NA & NA & NA \\
\hline 11 & 13 & 13 & 13 & 13 & 13 & NA & NA & NA & NA & NA \\
\hline 25 & 31 & 31 & 31 & 31 & 32 & NA & NA & NA & NA & NA \\
\hline 111,223 & 100,200 & 111,885 & 85,870 & 107,034 & 107,365 & 82,091 & 81,142 & 82,153 & 84,251 & 90,185 \\
\hline 639 & 482 & 529 & 343 & NA & NA & NA & NA & NA & NA & NA \\
\hline 221 & 166 & 170 & 130 & NA & NA & NA & NA & NA & NA & NA \\
\hline 1 & 1 & 1 & 1 & 1 & 1 & NA & NA & NA & NA & NA \\
\hline 1 & 1 & 1 & 1 & 1 & 1 & NA & NA & NA & NA & $A$ \\
\hline
\end{tabular}

Gas Fired

Sulfur Dioxide

Nitrogen Oxide

Methane

Nitrous Oxide

Petroleum Fired

Carbon Dioxide

Sulfur Dioxide

Nitrogen Oxide

Methane

Nitrous Oxide

Carbon Dioxide

Sulfur Dioxide

Nitrogen Oxide

Methane

Nitrous Oxide

Other ${ }^{1}$

Carbon Dioxide

Sulfur Dioxide 2

Nitrogen Oxide 2

Methane

Nitrous Oxide 3

194,999
1
565
0
0

310,190

319,119

336,866

232

262

359

422

1

$$
1
$$

NA NA

$\begin{array}{rr}\text { NA } & \text { NA } \\ 55 & 210\end{array}$

NA

326,174

327,857

4

44,001

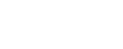

379,553

$270 \quad N A$
1

NA
NA
1
1

NA
NA
NA
NA

NA NA

NA

NA

NA

NA

NA

NA

NA NA

$$
\text { NA }
$$$$
\text { NA }
$$

NA

NA

NA

NA

NA

$\begin{array}{llll}49 & 59 & 55 & 210\end{array}$

NA

NA
NA
NA
1

14,290

15,024

15,806

16,535

16,834

NA

NA

NA

NA

NA

NA

$\begin{array}{ll}235 & 180 \\ \text { NA } & \text { NA }\end{array}$

NA

NA

NA

NA

NA

NA

NA NA

NA

NA

NA

Total

Carbon Dioxide

Sulfur Dioxide

\begin{abstract}
15,909
\end{abstract}
$\begin{array}{rrr}2,512,498 & 2,478,216 & 2,480,862 \\ 11,396 & 10,850 & 10,293\end{array}$

$511,9472,533$

$2,791,819 \quad 2,933,621 \quad 3,1$

NA

NA

NA 


\begin{tabular}{|c|c|c|c|c|c|c|c|c|c|c|c|}
\hline Nitrogen Oxide & 6,663 & 5,330 & 4,917 & 4,699 & 4,119 & 3,742 & 2,585 & 2,312 & 2,345 & 2,379 & 2,390 \\
\hline Mercury & NA & NA & NA & 50,081 & 50,695 & 53,306 & 41,595 & 26,503 & 20,653 & 18,283 & 16,872 \\
\hline Nitrous Oxide & 26 & 33 & 33 & 33 & 33 & 33 & NA & NA & NA & NA & NA \\
\hline
\end{tabular}

Sources: EIA, Annual Energy Outlook 2006, DOE/EIA-0383 (2005) (Washington, D.C., February 2006), Tables A8 and A18; EIA, Emissions of Greenhouse Gases in the United States 2004, DOE/EIA-0573(2003) (Washington, D.C., November 2005) Tables 10, 17, 25, 29; and EPA, National Emission Inventory Air Pollutant Emission Trends, "Average Annual Emissions, All Criteria Pollutants," August 2004, http://www.epa.gov/ttn/chief/trends/index.html.

\section{Notes:}

Emissions from electric-power sector only.

${ }^{1}$ Emissions total less than 500 tons.

${ }^{2}$ Emissions from plants fired by other fuels; includes internal-combustion generators.

${ }_{4}^{3}$ Emissions from wood-burning plants.

${ }^{4}$ Sulfur hexafluoride (SF6) is a colorless, odorless, nontoxic, and nonflammable gas used as an insulator in electric T\&D equipment. SF6 has a 100 -year global warming potential that is 22,200 times that of carbon dioxide and has an atmospheric lifetime of 3,200 years.

$\mathrm{NA}=$ not available 


\title{
Table 11.2 - Installed Nameplate Capacity of Utility Steam-Electric Generators With Environmental Equipment
}

(Megawatts)

Coal Fired
Particulate Collectors
Cooling Towers
Scrubbers
Total $^{1}$

\author{
1990
}

$\underline{2000}$

$\underline{2001}$

$\underline{2002}$

$\underline{2003}$

$\underline{2004}$

315,681
134,199
69,057
317,522

321,636
146,093
89,675
328,741

329,187

329,459

328,587

155,158

154,747

154,750

99,257

97,804
329,187

98,363

328,587

\section{NA}

NA

NA

NA

Petroleum and Gas Fired

Particulate Collectors

Cooling Towers

33,639
28,359
65
59,372

31,090
29,427
0
57,697

31,575

29,879

29,422

55,770

34,649

45,747

310

310

Total $^{1}$

59,372

61,634

71,709

81,493

NA

NA

NA

NA

Total

Particulate Collectors
Cooling Towers
Scrubbers
Total $^{1}$

$\begin{array}{rr}349,319 & 352,727 \\ 162,557 & 175,520 \\ 69,122 & 89,675 \\ 376,894 & 386,438\end{array}$

360,762
189,396
97,988
390,821

359,338
200,497
98,673
401,168

358,009

355,782

210,928

214,989

99,567

101,492

Source: EIA, Annual Energy Review 2004, DOE/EIA-0384(2004) (Washington, D.C., September 2005), Table 12.8. 2004 Total Data: EIA Electric Power Annual. DOE/EIA-0348(2004), http://www.eia.doe.gov/cneaf/electricity/epa/epat5p2.html, Table 5.2.

\section{Notes:}

${ }^{1}$ Components are not additive, because some generators are included in more than one category.

Through 2000, data are for electric utilities with fossil-fueled, steam-electric capacity of 100 megawatts or greater. Beginning in 2001, data are for electric utilities and unregulated generating plants (independent power producers, commercial plants, and industrial plants) with fossil-fueled or combustible renewable steam-electric capacity of 100 megawatts or greater.

$\mathrm{NA}=$ not available 
Table 11.3 - EPA-Forecasted Nitrogen Oxide, Sulfur Dioxide, and Mercury Emissions from Electric Generators

\begin{tabular}{|c|c|c|c|c|c|c|c|c|}
\hline & \multicolumn{4}{|c|}{ EPA Base Case 2004} & \multicolumn{4}{|c|}{ EPA CAIR Case 2004} \\
\hline & $\underline{2007}$ & $\underline{2010}$ & $\underline{2015}$ & $\underline{2020}$ & $\underline{2007}$ & $\underline{2010}$ & $\underline{2015}$ & $\underline{2020}$ \\
\hline $\mathrm{SO}_{2}$ (Thousand Tons) & 10,374 & 9,908 & 9,084 & 8,876 & 7,733 & 6,351 & 5,227 & 4,480 \\
\hline NOx (Thousand Tons) & 3,665 & 3,679 & 3,721 & 3,758 & 3,600 & 2,453 & 2,212 & 2,231 \\
\hline $\mathrm{CO}_{2}$ (Thousand Tons) & 2,391 & 2,470 & 2,599 & 2,796 & 2,365 & 2,452 & 2,571 & 2,776 \\
\hline
\end{tabular}

Source: Environmental Protection Agency (EPA), Runs Table for EPA Modeling Applications 2004, using IPM http://www.epa.gov/airmarkets/epaipm/iaqr.html, EPA Base Case for 2004 Analyses http://www.epa.gov/airmarkets/epa-ipm/iaqr/basecase2004.zip, and 2004 CAIR Case Final 2004 http://www.epa.gov/airmarkets/epa-ipm/iaqr/cair2004_final.zip

Notes:

Analytical Framework of IPM - EPA uses the Integrated Planning Model (IPM) to analyze the projected impact of environmental policies on the electric-power sector in the 48 contiguous states and the District of Columbia. Developed by ICF Resources Incorporated, and used to support public and private-sector clients, IPM is a multiregional, dynamic, deterministic linear programming model of the U.S. electric-power sector. - The model provides forecasts of least-cost capacity expansion, electricity dispatch, and emission-control strategies for meeting energy demand and environmental, transmission, dispatch, and reliability constraints. IPM can be used to evaluate the cost and emissions impacts of proposed policies to limit emissions of sulfur dioxide $\left(\mathrm{SO}_{2}\right)$, nitrogen oxides $(\mathrm{NOx})$, carbon dioxide $\left(\mathrm{CO}_{2}\right)$, and mercury $(\mathrm{Hg})$ from the electric-power sector 


\section{Table 11.4 - Origin of 2004 Allowable $\mathrm{SO}_{2}$ Emissions Levels}

\section{Number of $\mathrm{SO}_{2}$}

Allowances

\section{Type of Allowance Allocation}

Initial Allocation

Allowance Auctions

Opt-in Allowances

TOTAL 2004 ALLOCATION

Banked Allowances

TOTAL 2004 ALLOWABLE

\section{Explanation of Allowance Allocation Type}

$9,191,897$ Initial allocation is the number of allowances granted to units, based on the product of their historic utilization and emissions rates specified in the Clean Air Act.

250,000 The allowance auction provides allowances to the market that were set aside in a Special Allowance Reserve when the initial allowance allocation was made.

99,188 Opt-in Allowances are provided to units entering the program voluntarily. There were 11 optin units in 2004.

\section{$9,541,085$}

$8,646,818$

Banked Allowances are those allowances accrued in a unit's account from previous years, which can be used for compliance in 2004 or any future year.

\section{$18,187,903$}

Source: EPA, Acid Rain Program 2004 Progress Report, Document EPA-430-R-05-011, November 2005,

Figure 4. http://www.epa.gov/airmarkets/cmprpt/arp04/2004report.pdf 


\section{Table 12.1 - Renewable Energy Impacts Calculation}

\section{Conversion Formula:}

Step 1

Step 2

Step 3
Capacity (A) x Capacity Factor (B) x Annual Hours (C) = Annual Electricity Generation (D) Annual Electricity Generation $(D) \times$ Competing Heat Rate $(E)=$ Annual Output $(F)$ Annual Output (F) x Emissions Coefficient $(G)=$ Annual Emissions Displaced $(H)$
Technology
(A) Capacity (kW)
(B) Capacity Factor (\%)
(C) Annual Hours
(D) Annual Electricity Generation (kWh)
(E) Competing Heat Rate (Btu/kWh)
(F) Annual Output (Trillion Btu)
(G) Carbon Coefficient (MMTCB/Trillion Btu)
(H) Annual Carbon Displaced (MMTC)

\begin{tabular}{rrrrrr} 
Wind & Geothermal & Biomass & $\underline{\text { Hydropower }}$ & PV & Solar Thermal \\
\cline { 2 - 4 } $11,558,205$ & $2,232,495$ & $6,594,096$ & $78,312,583$ & 280,355 & 388,893 \\
$36.0 \%$ & $90.0 \%$ & $80.0 \%$ & $44.2 \%$ & $22.5 \%$ & $24.4 \%$ \\
8,760 & 8,760 & 8,760 & 8,760 & 8,760 & 8,760 \\
$36,449,954,187$ & $17,600,991,128$ & $46,211,427,727$ & $303,176,455,525$ & $552,579,314$ & $831,235,472$ \\
10,107 & 10,107 & 10,107 & 10,107 & 10,107 & 10,107 \\
368 & 178 & 467 & 3,064 & 6 & 8 \\
0.01783 & 0.01783 & 0.01783 & 0.01783 & 0.01783 & 0.01783 \\
6.569 & 3.172 & 8.328 & 54.635 & 0.100 & 0.128
\end{tabular}

\section{Sources:}

Capacity: Projected values for the year 2006 from EIA, Annual Energy Outlook 2006, DOE/EIA-0383 (2006) (Washington, D.C., February 2006), Table A16, 2005.

Capacity factors: Hydropower calculated from EIA, Annual Energy Outlook 2005, DOE/EIA-0383 (2005) (Washington, D.C., February 2005$)$, Table A16. All others based on DOE, Renewable Energy Technology Characterizations, EPRI TR-109496, 1997, and program data.

Heat Rate: EIA, Annual Energy Review 2004, DOE/EIA-0384(2004) (Washington, D.C., August 2005), Table A6.

Carbon Coefficient: DOE, GPRA2003 Data Call, Appendix B, page B-16, 2003.

\section{Notes:}

For illustrative purposes only, displacement of fossil generation depends on power system generation portfolio and dispatch order.

Capacity values exclude combined-heat-and-power (CHP) data, but include end-use sector (industrial and commercial) non-CHP data.

Competing heat rate from Fossil-Fueled Steam-Electric Plants heat rate. 


\section{Table 12.2 - Number of Home Electricity Needs Met Calculation}

$$
\text { Conversion Formula: } \quad \text { Step } 1 \quad \text { Capacity }(A) \times \text { Capacity Factor }(B) \times \text { Annual Hours }(C)=\text { Annual Electricity Generation }(D)
$$

Step 2 Annual Electricity Generation $(D) /$ Average Consumption $(E)=$ Number of Households $(F)$

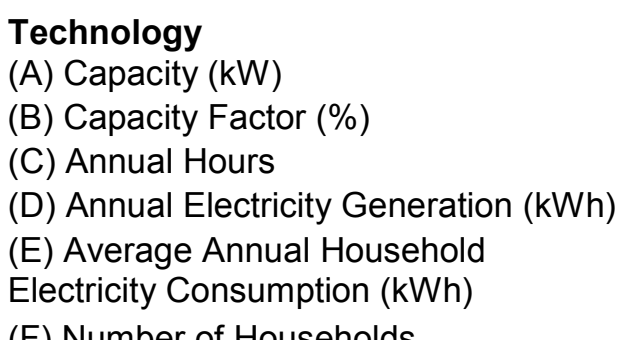

$\begin{array}{rrr}\frac{\text { Wind }}{11,558,205} & \text { Geothermal } & \text { Biomass } \\ 36.0 \% & 90,232,495 & 6,594,096 \\ 8,760 & 8,760 & 80.0 \% \\ 8,760 \\ 36,449,954,187 & 17,600,991,128 & 46,211,427,727 \\ & & \\ 11,586 & 11,586 & 11,586 \\ 3,148,804 & 1,520,497 & 3,992,068\end{array}$

$\begin{array}{r}\text { Hydropower } \\ \hline 78,312,583 \\ 44.2 \% \\ 8,760 \\ \hline 176,455,525\end{array}$

$303,176,455,525$

11,586
$26,190,515$

$\begin{array}{rr}\text { PV } & \text { Solar Thermal } \\ 280,355 & 388,893 \\ 22.5 \% & 24.4 \% \\ 8,760 & 8,760 \\ 52,579,314 & 831,235,472 \\ & \\ 11,586 & 11,586 \\ 47,736 & 71,808\end{array}$

Sources: Capacity: Projected values for the year 2006 from EIA, Annual Energy Outlook 2006, DOE/EIA-0383 (2006) (Washington, D.C., February 2006), Table A16, 2006.

Capacity factors: Hydropower calculated from EIA, Annual Energy Outlook 2005, DOE/EIA-0383 (2005) (Washington, D.C., February 2005), Table A16. All others based on DOE, Renewable Energy Technology Characterizations, EPRI TR-109496, 1997, and program data.

Household electricity consumption: Calculated from EIA, Annual Energy Outlook 2006, DOE/EIA-0383 (2006) (Washington, D.C., February), Tables A4 and A8, 2006.

Notes:

For illustrative purposes only.

Capacity values exclude combined-heat-and-power (CHP) data, but include end-use sector (industrial and commercial) non-CHP data. 


\section{Table 12.3 - Coal-Displacement Calculation}

Conversion Formula: $\quad$ Step $1 \quad$ Capacity $(A)$ x Capacity Factor $(B)$ x Annual Hours $(C)=$ Annual Electricity Generation $(D)$

Step $2 \quad$ Annual Electricity Generation $(D) \times$ Conversion Efficiency $(E)=$ Total Output $(F)$

Step 3 Total Output (F) / Fuel Heat Rate (G) = Quantity Fuel (H)
Technology
(A) Capacity (kW)
(B) Capacity Factor
$(\%)$
(C) Annual Hours
(D) Annual Electricity
Generation (kWh)
(E) Competing Heat
Rate (Btu/kWh)
(F) Total Output
(Million Btu)
(G) Coal Heat Rate
(Btu per short ton)
(H) Coal (short tons)

Wind
$11,558,205$
$36.0 \%$
8,760
$36,449,954,187$
10,107
$368,399,686$
$20,411,000$
$18,049,076$

\begin{tabular}{r} 
Geothermal \\
\hline $2,232,495$ \\
$90.0 \%$ \\
8,760 \\
$17,600,991,128$ \\
10,107 \\
$177,893,217$ \\
$20,411,000$ \\
$8,715,556$
\end{tabular}

Biomass
$6,594,096$
$80.0 \%$
8,760
$46,211,427,727$
10,107
$467,058,900$
$20,411,000$
$22,882,705$
Hydropower
$78,312,583$
$44.2 \%$
8,760

$303,176,455,525$

10,107

$3,064,204,435$

$20,411,000$

$150,125,150$

$22,882,705$

$\begin{array}{rr}\underline{\text { PV }} & \text { Solar Thermal } \\ 280,355 & 388,893 \\ 22.5 \% & 24.4 \% \\ 8,760 & 8,760 \\ 552,579,314 & 831,235,472 \\ & 10,107 \\ 10,107 & 8,401,296 \\ 5,584,919 & 20,411,000 \\ 20,411,000 & 411,606\end{array}$

Sources: Capacity: EIA, Annual Energy Outlook 2006, DOE/EIA-0383 (2006) (Washington, D.C., February 2006), Table A16, 2006.

Capacity factors: Hydropower calculated from EIA, Annual Energy Outlook 2005, DOE/EIA-0383 (2005) (Washington, D.C., February 2005), Table A16. All others based on DOE, Renewable Energy Technology Characterizations, EPRI TR-109496, 1997 and Program data.

Conversion Efficiency: EIA, Annual Energy Review 2004, DOE/EIA-0384(2003) (Washington, D.C., August 2005), Table A6.

Heat Rate: Annual Energy Outlook 2006, DOE/EIA-0383 (2006) (Washington, D.C., February 2006), Table H1.

\section{Notes:}

For illustrative purposes only, displacement of fossil generation depends on power system generation portfolio and dispatch order.

Capacity values exclude combined-heat-and-power (CHP) data, but include end-use sector (industrial and commercial) non-CHP data. 


\section{Table 12.4 - National $\mathrm{SO}_{2}$ and Heat Input Data}

1980

$\mathrm{SO}_{2}$ (lbs)

$\mathrm{SO}_{2}$ Heat Factor (Ib/MMBtu)

$\mathrm{NO}_{x}$ (lbs)

$\mathrm{NO}_{\mathrm{x}}$ Heat Factor (Ib/MMBtu)

Heat (MMBtu)

$34,523,334,000$

1.935

$17,838,745,941$
1985

\section{$32,184,330,000$}

1.748

$18,414,433,865$

$\underline{1990}$
$31,466,566,000$
1.599

$-$

$19,684,094,492$
1995

$23,671,357,600$

1.081

$11,682,226,600$

0.534

$21,889,662,875$ $\underline{2000}$

$22,404,150,534$

0.875

$12,024,262,800$

0.470

$25,606,076,726$
2004

$20,518,221,256$

0.778

10,209,031,650 $26,358,516,161$

Source: EPA, Clean Air Markets Web site - Data and Maps, Emissions section, http://cfpub.epa.gov/gdm/ accessed February 2006. 
Table $12.5-\mathrm{SO}_{2}, \mathrm{NOx}, \mathrm{CO}_{2}$ Emission Factors for Coal-Fired and Noncoal-Fired Title IV Affected Units

\begin{tabular}{|c|c|c|c|c|c|c|c|c|c|}
\hline & 1996 & 1997 & $\underline{1998}$ & $\underline{1999}$ & 2000 & 2001 & 2002 & 2003 & $\underline{2004}$ \\
\hline \multicolumn{10}{|c|}{$\mathrm{SO}_{2}(\mathrm{lbs} / \mathrm{mmBtu})$} \\
\hline Coal & 1.241 & 1.245 & 1.222 & 1.166 & 1.036 & 1.008 & 0.976 & 0.968 & 0.941 \\
\hline Noncoal & 0.246 & 0.256 & 0.318 & 0.267 & 0.200 & 0.220 & 0.126 & & \\
\hline Total & 1.096 & 1.093 & 1.058 & 0.999 & 0.875 & 0.843 & 0.794 & & \\
\hline \multicolumn{10}{|c|}{$\mathrm{NO}_{\mathrm{x}}(\mathrm{lbs} / \mathrm{mmBtu})$} \\
\hline Coal & 0.568 & 0.559 & 0.532 & 0.487 & 0.444 & 0.425 & 0.408 & 0.375 & 0.340 \\
\hline Noncoal & 0.221 & 0.234 & 0.251 & 0.244 & 0.210 & 0.176 & 0.128 & & \\
\hline Total & 0.518 & 0.509 & 0.481 & 0.442 & 0.399 & 0.373 & 0.348 & & \\
\hline \multicolumn{10}{|c|}{$\mathrm{CO}_{2}(\mathrm{lbs} / \mathrm{mmBtu})$} \\
\hline Coal & 206.377 & 205.537 & 205.677 & 205.586 & 205.646 & 205.627 & 205.672 & 201.741 & 201.513 \\
\hline Noncoal & 132.731 & 130.804 & 131.685 & 132.001 & 133.110 & 130.159 & 126.858 & & \\
\hline Total & 195.682 & 194.056 & 192.256 & 191.956 & 191.672 & 189.809 & 188.813 & & \\
\hline
\end{tabular}

Source: EPA, Acid Rain Program Compliance Report 2001, Emission Scorecard, updated April 2004, Table 1,

http://www.epa.gov/airmarkets/emissions/score01/index.html, and EPA, Clean Air Markets Web site - Data and Maps, Emissions section, http://cfpub.epa.gov/gdm/ accessed March 2006. 


\section{Table 12.6a - Sulfur Dioxide Uncontrolled Emission Factors, Electricity Generators}

\begin{tabular}{ll} 
Fuel & \multicolumn{1}{c}{ Emissions } \\
Agricultural Byproducts & Lbs per ton \\
Blast Furnace Gas & Lbs per MMCF \\
Bituminous Coal* & Lbs per ton \\
Black Liquor & Lbs per ton *** \\
Distillate Fuel Oil* $^{*}$ & Lbs per MG \\
Jet Fuel $^{*}$ & Lbs per MG \\
Kerosene $^{*}$ & Lbs per MG \\
Landfill Gas $^{*}$ & Lbs per MMCF \\
Lignite Coal* $^{*}$ & Lbs per ton \\
Municipal Solid Waste & Lbs per ton \\
Natural Gas & Lbs per MMCF \\
Other Biomass Gas & Lbs per MMCF \\
Other Biomass Liquids & Lbs per MG \\
Other Biomass Solids & Lbs per ton \\
Other Gases & Lbs per MMCF \\
Other & Lbs per MMCF \\
Petroleum Coke* & Lbs per ton \\
Propane Gas & Lbs per MMCF \\
Residual Fuel Oil* & Lbs per MG \\
Synthetic Coal & Lbs per ton \\
Sludge Waste & Lbs per ton \\
Subbituminous Coal* & Lbs per ton $* * *$ \\
Tire Derived Fuel* & Lbs per ton \\
Waste Coal & Lbs per ton \\
Wood Waste Liquids & Lbs per MG \\
Wood Waste Solids & Lbs per ton \\
Waste Oil* & Lbs per MG \\
&
\end{tabular}

Cyclone
0.08
3.5
38
7
142
142
142
3.5
30
1.7
0.6
3.5
1.42
0.08
3.5
0.6
39
0.6
157
38
2.8
35
38
38
1.42
0.08
147

\begin{tabular}{rrrrr}
$\begin{array}{c}\text { Fluidized } \\
\text { Bed }\end{array}$ & $\begin{array}{c}\text { Opposed } \\
\text { Firing }\end{array}$ & $\begin{array}{c}\text { Spreader } \\
\text { Stoker }\end{array}$ & Tangential & All Other \\
0.35 & 0.08 & 0.08 & 0.08 & 0.08 \\
3.1 & 3.5 & 3.5 & 3.5 & 3.5 \\
0.7 & 38 & 38 & 38 & 38 \\
14.2 & 7 & 7 & 7 & 7 \\
14.2 & 142 & 142 & 142 & 142 \\
14.2 & 142 & 142 & 142 & 142 \\
0.35 & 142 & 142 & 142 & 142 \\
1 & 3.5 & 3.5 & 3.5 & 3.5 \\
0.17 & 30 & 30 & 30 & 30 \\
0.06 & 1.7 & 1.7 & 1.7 & 1.7 \\
0.35 & 0.6 & 0.6 & 0.6 & 0.6 \\
1.42 & 3.5 & 3.5 & 3.5 & 3.5 \\
0.01 & 1.42 & 1.42 & 1.42 & 1.42 \\
0.35 & 0.08 & 0.08 & 0.08 & 0.08 \\
0.06 & 3.5 & 3.5 & 3.5 & 3.5 \\
3.9 & 0.6 & 0.6 & 0.6 & 0.6 \\
0.06 & 39 & 39 & 39 & 39 \\
15.7 & 0.6 & 0.6 & 0.6 & 0.6 \\
3.1 & 157 & 157 & 157 & 157 \\
0.28 & 38 & 38 & 38 & 38 \\
3.1 & 2.8 & 2.8 & 2.8 & 2.8 \\
3.8 & 35 & 38 & 35 & 35 \\
3.1 & 38 & 38 & 38 & 38 \\
1.42 & 38 & 38 & 38 & 38 \\
0.01 & 0.42 & 1.42 & 1.42 & 1.42 \\
14.7 & 147 & 0.08 & 0.08 & 0.08 \\
& & 147 & 147 & 147 \\
\hline & & & &
\end{tabular}


Source: EIA, Electric Power Annual 2004, DOE/EIA-0348(2004) November 2005, Table A1.

Notes:

${ }^{1}$ Lbs = pounds, MMCF = million cubic feet, MG = thousand gallons .

* For these fuels, emissions are estimated by multiplying the emissions factor by the physical volume of fuel and the sulfur percentage of the fuel (other fuels do not require the sulfur percentage in the calculation). Note that EIA data do not provide a sulfur content for TDF. The value used (1.56 percent) is from http://www.epa.gov/appcdwww/aptb/EPA-600-R-01-109A.pdf, Table A-11.

** Source is EPA emission factors reported in http://www.epa.gov/ttn/chief/ap42/ and http://www.epa.gov/ttn/chief/software/fire/index.html.

*** Although SLW and BLQ consist substantially of liquids, these fuels are measured and reported to EIA in tons. 


\section{Table 12.6b - Nitrogen Oxide Uncontrolled Emissions Factors, Electricity Generators}

\begin{tabular}{|c|c|c|c|c|c|c|c|}
\hline \multirow[b]{2}{*}{$\begin{array}{c}\text { Fuel } \\
\text { Agricultural Byproducts }\end{array}$} & \multirow[b]{2}{*}{$\begin{array}{l}\text { Emissions Units } \\
\text { Lbs per ton }\end{array}$} & \multicolumn{6}{|c|}{ Boiler Type/Firing Configuration ${ }^{1}$} \\
\hline & & $\begin{array}{r}\text { Cyclone } \\
1.20\end{array}$ & $\begin{array}{l}\text { Fluidized } \\
\text { Bed } \\
1.20\end{array}$ & $\begin{array}{l}\text { Opposed } \\
\text { Firing } \\
1.20\end{array}$ & $\begin{array}{c}\text { Spreader } \\
\text { Stoker } \\
1.20\end{array}$ & $\begin{array}{r}\text { Tangential } \\
1.20\end{array}$ & $\begin{array}{l}\text { All Other } \\
1.20\end{array}$ \\
\hline Blast Furnace Gas & Lbs per MMCF & 15.40 & 15.40 & 15.40 & 15.40 & 15.40 & 15.40 \\
\hline Bituminous Coal & Lbs per ton & 33.00 & 5.00 & 22.00 & 11.00 & $15.0[14.0]$ & $22.0[31.0]$ \\
\hline Black Liquor & Lbs per ton ${ }^{* * *}$ & 1.50 & 1.50 & 1.50 & 1.50 & 1.50 & 1.50 \\
\hline Distillate Fuel Oil & Lbs per MG & 24.00 & 24.00 & 24.00 & 24.00 & 24.00 & 24.00 \\
\hline Jet Fuel & Lbs per MG & 24.00 & 24.00 & 24.00 & 24.00 & 24.00 & 24.00 \\
\hline Kerosene & Lbs per MG & 24.00 & 24.00 & 24.00 & 24.00 & 24.00 & 24.00 \\
\hline Landfill Gas & Lbs per MMCF & 72.40 & 72.40 & 72.40 & 72.40 & 72.40 & 72.40 \\
\hline Lignite Coal & Lbs per ton & 15.00 & 3.60 & 13.00 & 5.80 & 7.10 & $7.1[13.0]$ \\
\hline Municipal Solid Waste & Lbs per ton & 5.90 & 5.90 & 5.90 & 5.90 & 5.90 & 5.90 \\
\hline Natural Gas & Lbs per MMCF & 280.00 & 280.00 & 280.00 & 280.00 & 170.00 & 280.00 \\
\hline Other Biomass Gas & Lbs per MMCF & 72.40 & 72.40 & 72.40 & 72.40 & 72.40 & 72.40 \\
\hline Other Biomass Liquids & Lbs per MG & 1.66 & 1.66 & 1.66 & 1.66 & 1.66 & 1.66 \\
\hline Other Biomass Solids & Lbs per ton & 1.20 & 1.20 & 1.20 & 1.20 & 1.20 & 1.20 \\
\hline Other Gases & Lbs per MMCF & 14.90 & 14.90 & 14.90 & 14.90 & 14.90 & 14.90 \\
\hline Other & Lbs per MMCF & 1.50 & 1.50 & 1.50 & 1.50 & 1.50 & 1.50 \\
\hline Petroleum Coke & Lbs per ton & 21.00 & 21.00 & 21.00 & 21.00 & 21.00 & 21.00 \\
\hline Propane Gas & Lbs per MMCF & 19.00 & 19.00 & 19.00 & 19.00 & 19.00 & 19.00 \\
\hline Residual Fuel Oil & Lbs per MG & 47.00 & 47.00 & 47.00 & 47.00 & 32.00 & 47.00 \\
\hline Synthetic Coal & Lbs per ton & 33.00 & 5.00 & 22.00 & 11.00 & 15.00 & 22.00 \\
\hline Sludge Waste & Lbs per ton & 5.00 & 5.00 & 5.00 & 5.00 & 5.00 & 5.00 \\
\hline Subbituminous Coal & Lbs per ton ${ }^{* * *}$ & 17.00 & 5.00 & 12.00 & 8.80 & 8.40 & $12.0[24.0]$ \\
\hline
\end{tabular}




\begin{tabular}{|c|c|c|c|c|c|c|c|}
\hline Tire Derived Fuel & Lbs per ton & 33.00 & 5.00 & 22.00 & 11.00 & 15.00 & 22.00 \\
\hline Waste Coal & Lbs per ton & 21.70 & 21.70 & 21.70 & 21.70 & 21.70 & 21.70 \\
\hline Wood Waste Liquids & Lbs per MG & 1.66 & 1.66 & 1.66 & 1.66 & 1.66 & 1.66 \\
\hline Wood Waste Solids & Lbs per ton & 1.50 & 1.50 & 1.50 & 1.50 & 1.50 & 1.50 \\
\hline Waste Oil & Lbs per MG & 19.00 & 19.00 & 19.00 & 19.00 & 19.00 & 19.00 \\
\hline
\end{tabular}

Source: EIA, Electric Power Annual 2004, DOE/EIA-0348(2004) November 2005, Table A1.

Notes:

${ }^{1}$ All Dry-Bottom Boilers, Except Wet-Bottom as indicated by values in brackets

${ }^{2} \mathrm{Lbs}=$ pounds, MMCF = million cubic feet, MG = thousand gallons.

** Source is EPA emission factors reported in http://www.epa.gov/ttn/chief/ap42/ and http://www.epa.gov/ttn/chief/software/fire/index.html.

${ }^{* * *}$ Although Sludge Waste and Black Liquor consist substantially of liquids, these fuels are measured and reported to EIA in tons. 
Table 12.6c - Uncontrolled Carbon Dioxide Emissions Factors, Electricity Generators

\begin{tabular}{lr} 
Fuel & \multicolumn{2}{c}{ Factor } \\
& (Ibs of CO2 per MMBtu) \\
Blast Furnace Gas & 116.97 \\
Bituminous Coal & 205.45 \\
Distillate Fuel Oil & 161.27 \\
Geothermal & 0.34 \\
Jet Fuel & 159.41 \\
Kerosene & 159.41 \\
Landfill Gas & 115.12 \\
Lignite Coal & 215.53 \\
Municipal Solid Waste & 14.63 \\
Natural Gas & 116.97 \\
Other Biomass Gas & 115.11 \\
Other Gases & 141.54 \\
Petroleum Coke & 225.13 \\
Propane Gas & 139.04 \\
Residual Fuel Oil & 173.72 \\
Synthetic Coal & 205.45 \\
Subbituminous Coal & 212.58 \\
Waste Coal & 205.16 \\
Waste Oil & 163.61
\end{tabular}

Source: EIA, Electric Power Annual 2004, DOE/EIA-0348(2004), November 2005, Table A1.

* $\mathrm{CO}_{2}$ factors do not vary by boiler type or firing configuration. 


\section{Table 12.7 - Global Warming Potentials (GWP)}

(100-year time horizon)

Gas

Carbon dioxide $(\mathrm{CO} 2)$

Methane $\left(\mathrm{CH}_{4}\right)^{1}$

Nitrous oxide $\left(\mathrm{N}_{2} \mathrm{O}\right)$

HFC-23

HFC-32

HFC-125

$\mathrm{HFC}-134 \mathrm{a}$

HFC-143a

HFC-152a

HFC-227ea

HFC-236fa

HFC-4310mee

$\mathrm{CF}_{4}$

$\mathrm{C}_{2} \mathrm{~F}_{6}$

$\mathrm{C}_{4} \mathrm{~F}_{10}$

$\mathrm{C}_{6} \mathrm{~F}_{14}$

$\mathrm{SF}_{6}$
GWP

SAR

21

310

11,700

650

2,800

1,300

3,800

140

2,900

6,300

1,300

6,500

9,200

7,000

7,400

23,900

Source: EPA, Inventory of U.S. Greenhouse Gas Emissions and Sinks: 1990-2003, EPA 430-R-05-003 (Final Version: April 2005$)$, Table ES-1.

Notes:

The GWP of a greenhouse gas is the ratio of global warming, or radiative forcing - both direct and indirect - from one unit mass of a greenhouse gas to that of one unit mass of carbon dioxide over a period of time.

GWP from Intergovernmental Panel and Climate Change (IPCC) Second Assessment Report (SAR) and Third Assessment Report (TAR).

Although the GWPs have been updated by the IPCC, estimates of emissions presented in this report use the GWPs from the Second Assessment Report. The UNFCCC reporting guidelines for national inventories were updated in 2002, but continue to require the use of GWPs from the SAR so that current estimates of aggregated greenhouse gas emissions for 1990 through 2001 are consistent with estimates developed prior to the

publication of the TAR. Therefore, to comply with international reporting standards under the UNFCCC, official emission estimates are reported by the United States using SAR GWP values.

${ }^{1}$ The methane GWP includes direct effects and those indirect effects, due to the production of tropospheric ozone and stratospheric water vapor. The indirect effect due to the production of $\mathrm{CO}_{2}$ is not included. 
Table 12.8 - Approximate Heat Content of Selected

Fuels for Electric-Power Generation

\section{Fossil Fuels ${ }^{1}$}

Residual Oil (million Btu per barrel) $\quad 6.287$

Distillate Oil (million Btu per barrel) $\quad 5.799$

Natural Gas (Btu per million cubic $\mathrm{ft}$ ) 1,027

Coal (million Btu per Short Ton) 20.411

Biomass Materials ${ }^{2}$

Switchgrass Btu per pound $\quad 7,341$

Bagasse, Btu per pound $\quad 6,065$

Rice Hulls, Btu per pound $\quad 6,575$

Poultry Litter, Btu per pound $\quad 6,187$

Solid wood waste, Btu per pound $\quad 6,000-8,000$

\section{Sources:}

1. EIA, Annual Energy Outlook 2006, DOE/EIA-0383 (2006) (Washington, D.C., February 2006), Table G1.

2. Animal Waste Screening Study, Electrotek Concepts Inc., Arlington, VA. June 2001. 


\section{Table 12.9 - Approximate Heat Rates for Electricity}

(Btu per Kilowatthour)

(980

Fossil-Fueled Steam-Electric Plants ${ }^{1,2}$

10,388

$\underline{1990}$

$\underline{2000}$

2001

$\underline{2002}$

$\underline{2003}$

$\underline{2004}$

Nuclear Steam-Electric Plants ${ }^{3}$

10,908

10,402

10,201

10,146

10,119

10,107

10,107

Geothermal Energy Plants ${ }^{4}$

21,639

21,096

21,017

21,017

21,017

21,017

10,439

Source: EIA, Annual Energy Review 2004, DOE/EIA-0384 (2004) (Washington, D.C., August 2005), Table A6 Notes:

${ }^{1}$ Through 2000, used as the thermal conversion factor for wood and waste electricity net generation at electric utilities. For all years, used as the thermal conversion factor for hydro, solar, and wind electricity net generation.

${ }^{2}$ Through 2000, heat rates are for fossil-fueled steam-electric plants at electric utilities. Beginning in 2001 , heat rates are for all fossil-fueled plants at electric utilities and independent power producers.

${ }^{3}$ Used as the thermal-conversion factor for nuclear electricity net generation.

${ }^{4}$ Used as the thermal-conversion factor for geothermal electricity net generation. 


\section{Table 12.10 - Heating Degree-Days by Month}

$1980 \quad \underline{1990} \quad \underline{2000} \quad \underline{2001} \quad \underline{2002} \quad \underline{2003} \quad \underline{2004} \quad \underline{\text { Normal }}^{1}$

$\begin{array}{lrrrrrrrr}\text { January } & 887 & 728 & 886 & 935 & 778 & 944 & 957 & 917 \\ \text { February } & 831 & 655 & 643 & 725 & 670 & 801 & 769 & 732 \\ \text { March } & 680 & 535 & 494 & 669 & 624 & 572 & 487 & 593 \\ \text { April } & 338 & 321 & 341 & 302 & 282 & 344 & 302 & 345 \\ \text { May } & 142 & 184 & 115 & 115 & 185 & 165 & 105 & 159 \\ \text { June } & 49 & 29 & 29 & 29 & 23 & 41 & 28 & 39 \\ \text { July } & 5 & 6 & 12 & 8 & 3 & 4 & 5 & 9 \\ \text { August } & 10 & 10 & 12 & 6 & 8 & 5 & 16 & 15 \\ \text { September } & 54 & 56 & 69 & 71 & 38 & 62 & 42 & 77 \\ \text { October } & 316 & 246 & 244 & 267 & 299 & 261 & 241 & 282 \\ \text { November } & 564 & 457 & 610 & 400 & 561 & 477 & 484 & 539 \\ \text { December } & 831 & 789 & 1,005 & 696 & 813 & 784 & 788 & 817 \\ \text { Total } & 4,707 & 4,016 & 4,460 & 4,223 & 4,284 & 4,460 & 4,224 & 4,524\end{array}$

Source: EIA, Annual Energy Review 2004, DOE/EIA-0384(2004) (Washington, D.C., August 2005), Table 1.7

Notes:

${ }^{1}$ Based on calculations of data from 1971-2000

- This table excludes Alaska and Hawaii. - Degree-days are relative measurements of outdoor air temperature. Heating degree-days are deviations below the mean daily temperature of $65^{\circ} \mathrm{F}$. For example, a weather station recording a mean daily temperature of $40^{\circ} \mathrm{F}$ would report 25 heating degree-days. - Temperature information recorded by weather stations is used to calculate statewide degree-day averages based on resident state population. Beginning in 2002, data are weighted by the estimated 2000 population. The population-weighted state figures are aggregated into Census divisions and the national average. Web Pages: • For data not shown for 1951-1969, see http://www.eia.doe.gov/emeu/aer/overview.html.• For current data, see http://www.eia.doe.gov/emeu/mer/overview.html. Sources: • 1949 2003 and Normals-U.S. Department of Commerce, National Oceanic and Atmospheric Administration (NOAA), National Climatic Data

Center, Asheville, North Carolina, Historical Climatology Series 5-1. • 2004-Energy Information Administration, Monthly Energy Review, February 2004-January 2005 issues, Table 1.10, which reports data from NOAA, National Weather Service Climate Prediction Center, Camp Springs, Maryland. 


\section{Table 12.11 - Cooling Degree-Days by Month}

\section{0}

$1990 \quad \underline{2000}$

\section{$\underline{2001}$ \\ $\underline{2002}$}

$\underline{2003}$

$\underline{2004}$

Normal $^{1}$

January

February

March

April

May

June

July

August

September

October

November

December

Total

$\begin{array}{rrrr}9 & 15 & 10 & 3 \\ 4 & 14 & 10 & 12 \\ 13 & 21 & 25 & 11 \\ 23 & 29 & 28 & 37 \\ 95 & 86 & 131 & 114 \\ 199 & 234 & 221 & 220 \\ 374 & 316 & 284 & 302 \\ 347 & 291 & 302 & 333 \\ 192 & 172 & 156 & 138 \\ 42 & 57 & 50 & 46 \\ 10 & 16 & 8 & 18 \\ 5 & 9 & 4 & 11 \\ 1,313 & 1,260 & 1,229 & 1,245\end{array}$

8
6
17
53
92
242
369
331
202
57
11
5
1,393

$\begin{array}{rr}5 & 5 \\ 7 & 5 \\ 24 & 26 \\ 30 & 41 \\ 110 & 140 \\ 187 & 208 \\ 336 & 310 \\ 345 & 254 \\ 156 & 178 \\ 65 & 69 \\ 21 & 17 \\ 4 & 6 \\ 1,281 & 1,260\end{array}$

9
8
18
30
97
213
321
290
155
53
15
8
1,215

Source: EIA, Annual Energy Review 2004, DOE/EIA-0384(2004) (Washington, D.C., August 2005), Table 1.8

Notes:

${ }^{1}$ Based on calculations of data from 1971-2000

- This table excludes Alaska and Hawaii. - Degree-days are relative measurements of outdoor air temperature. Cooling degree-days are deviations above the mean daily temperature of $65^{\circ} \mathrm{F}$. For example, a weather station recording a mean daily temperature of $78^{\circ} \mathrm{F}$ would report 13 cooling degree-days. - Temperature information recorded by weather stations is used to calculate statewide degree-day averages based on resident state population. Beginning in 2002, data are weighted by the estimated 2000 population. The population-weighted state figures are aggregated into Census divisions and the national average. Web Pages: • For data not shown for 1951-1969, see http://www.eia.doe.gov/emeu/aer/overview.html. • For current data, see http://www.eia.doe.gov/emeu/mer/overview.html. Sources: • 1949-2003 and Normals-U.S. Department of Commerce, National Oceanic and Atmospheric Administration (NOAA), National Climatic Data Center, Asheville, North Carolina, Historical Climatology Series 5-2. • 2004-Energy Information Administration, Monthly Energy Review, February 2004-January 2005 issues, Table 1.11, which reports data from NOAA, National Weather Service Climate Prediction Center, Camp Springs, Maryland. 


\section{1 - Geographic Information System (GIS) Maps}

A Geographical Information System (GIS) is a computer-based system used to manipulate, manage, and analyze multidisciplinary geographic and related attribute data. The GIS system is composed of hardware, software, data, and expertise. A GIS system allows the user to perform several tasks, including data capture, data management, data manipulation, data analysis, and presentation of results in graphic or report forms.

All information in GIS is linked to a spatial reference used to store and access data. GIS data layers can be recombined or manipulated, and analyzed with other layers of information. The GIS allows identification of relationships between features, within a common layer or across layers - and data can be queried or manipulated based on the tabular and/or the spatial characteristics.

One set of maps (Figures 13.1, 13.3, 13.5, and 13.7) illustrates the natural renewable resource for the United States by quality of the resource. The transmission grid and the major load centers are overlaid on the resource maps. The major load centers represent the areas in the United States where the vast majority of electricity demand exists (large metropolitan areas). The maps featured here are simplified to make them easier to read. Higher-resolution resource maps are available online (see Online Resources later in this chapter.

One of the challenges facing renewable energy is that, in many cases, areas with excellent renewable energy resources have little demand for electricity - while many major load centers are far from areas with good renewable resources.

The other set of maps (Figures 13.2, 13.4, 13.6, and 13.8) shows the installed generating capacity from 1996 through 2005 by state. A number in the state shows generating capacity in MW, and a bar chart in the state shows the generating capacity over time.

\section{Biomass}

Biomass power utilizes biomass such as wood, agricultural waste, and yard waste through combustion. The biomass fuel is either directly combusted in a boiler, or gasified and then combusted, or turned into a liquid fuel that can be combusted (see the Biomass section of Chapter 2 for more detail on biomass technologies).

\section{Natural Resource}

The majority of biomass resources exist east of the Continental Divide (Figure 13.1). Biomass resources are derived from the vegetation. Because the western part of the United States has sparse vegetation, the biomass resource in the Western states is generally poor. The Eastern states have much higher-quality resources; and many major load centers in Eastern states are near areas with excellent biomass resources. Alaska has limited biomass resources, while Hawaii has excellent biomass resources on some of the islands. 


\section{Installed Capacity}

Biomass-generating capacity was nearly level during the past decade, with a slight decline in the past few years (Figure 13.2). The largest states, in terms of generating capacity, are Florida (1,051 MW), California (799 MW), and Maine (788 MW).

\section{Geothermal}

Geothermal technologies for power generation utilize heat from underground sources to generate electricity. Plants are currently operating in the Western United States (see the Geothermal section of Chapter 2 for more details on geothermal technologies).

\section{Natural Resource}

The majority of high-quality geothermal resources exist in the western part of the United States - and, in particular, the Southwest (Figure 13.3). Most of the major load areas in the Eastern states are not near any high-quality geothermal resources. The Western states are more promising, as several of the major load centers are in - or close to - high-quality geothermal resources. A good supply of high-quality geothermal resources exists in sparsely populated areas in the West. Alaska and Hawaii both have some areas with excellent geothermal resources.

\section{Installed Capacity}

Geothermal generation is currently located in three Western states (Figure 13.4). California is by far the largest (2,802 MW), followed by Nevada (272 MW) and Utah (38MW).

\section{Solar}

The two most commonly deployed solar power technologies are photovoltaic (PV) and concentrating solar thermal power (CSP) (see the Solar section of Chapter 2 for more information on solar technologies).

\section{Natural Resource}

The southern parts of the United States, and especially the southwest, have the greatest potential for solar energy (Figure 13.5). This is determined largely by latitude and weather patterns. Solar resources generally decline in quality, moving east and north from the Southwest. The Northeast, as a whole, generally has moderate-quality solar resources. Alaska has moderate solar resources, while Hawaii has good - to very good - solar resources.

\section{Installed Capacity}

This map features concentrating solar thermal power (CSP) generating capacity (Figure 13.6). Total CSP-generating capacity is virtually unchanged over the past decade.

California has the most CSP generating capacity, by far $(418 \mathrm{MW})$, followed by Arizona (10 MW), New York (0.5 MW), Nevada (0.3 MW), and Pennsylvania (0.3 MW). 


\section{Wind}

Wind power utilizes naturally occurring wind patterns to drive turbines that generate electricity (see the Wind section of Chapter 2 for more information on wind power technologies).

\section{Natural Resource}

The wind resources of the United States fall into two major categories: 1) onshore, and 2) offshore. So far, most of the wind resource assessments focused on onshore wind. Most of the best onshore wind resource is in the Midwestern states (Figure 13.7). Many of the major load centers in the Eastern states are not located near good wind resources, while some Western load centers are located close to high-quality wind resources.

\section{Installed Capacity}

Wind power is the most consistently growing renewable energy technology among those featured in this chapter (Figure 13.8). California is the largest state, in terms of capacity $(2,150 \mathrm{MW})$, with Texas close behind (1,995 MW). Iowa, the third-largest state (836 MW), has less than half the capacity of the largest states. Wind-generating capacity is growing rapidly in many states.

\section{Online Resources}

For more GIS information, including dynamic maps, GIS data, and analysis tools - as well as downloadable high-resolution maps - please see the NREL GIS Web site at http://www.nrel.gov/gis 


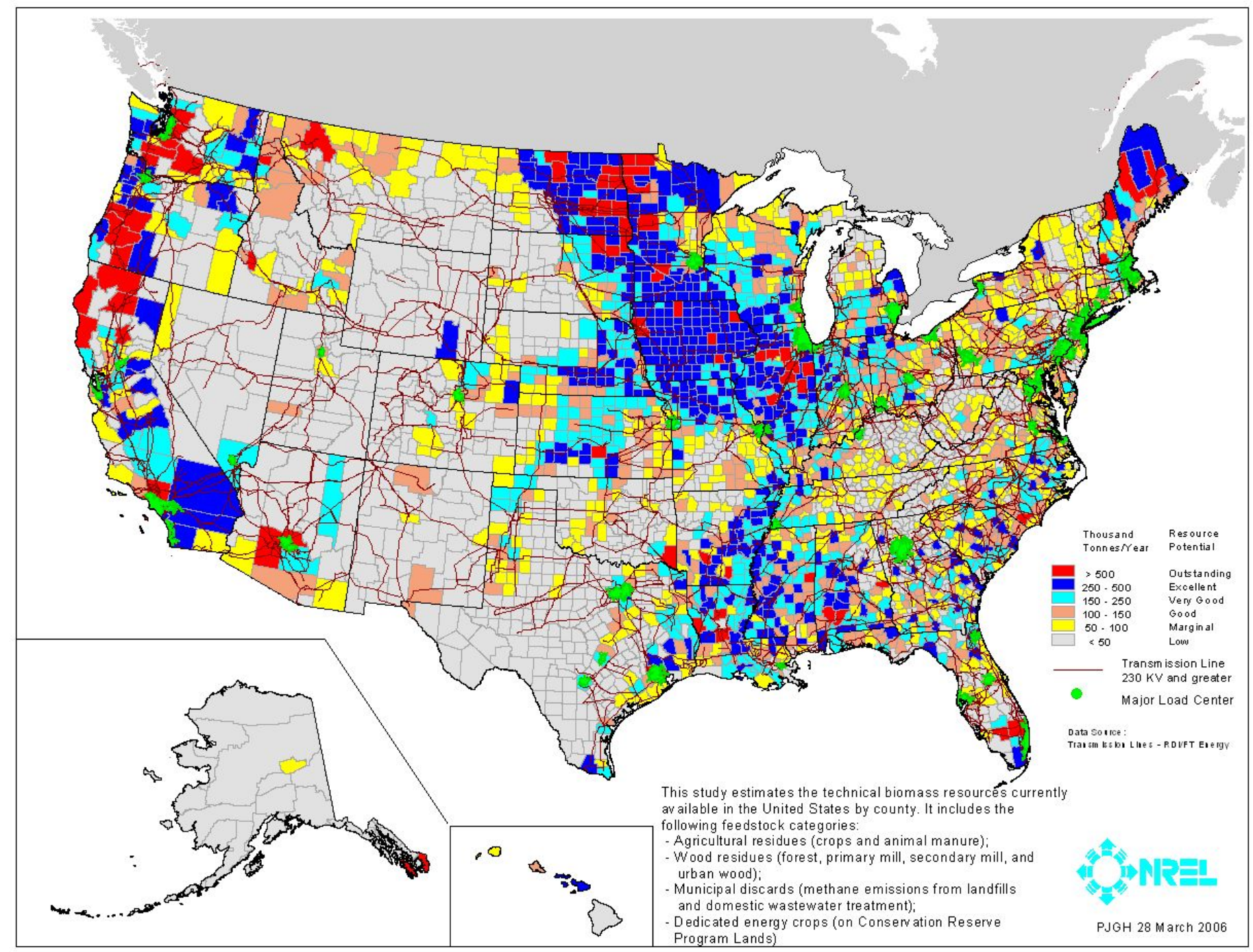

Figure 13.1. Biomass Resources, Transmission, and Load Centers 


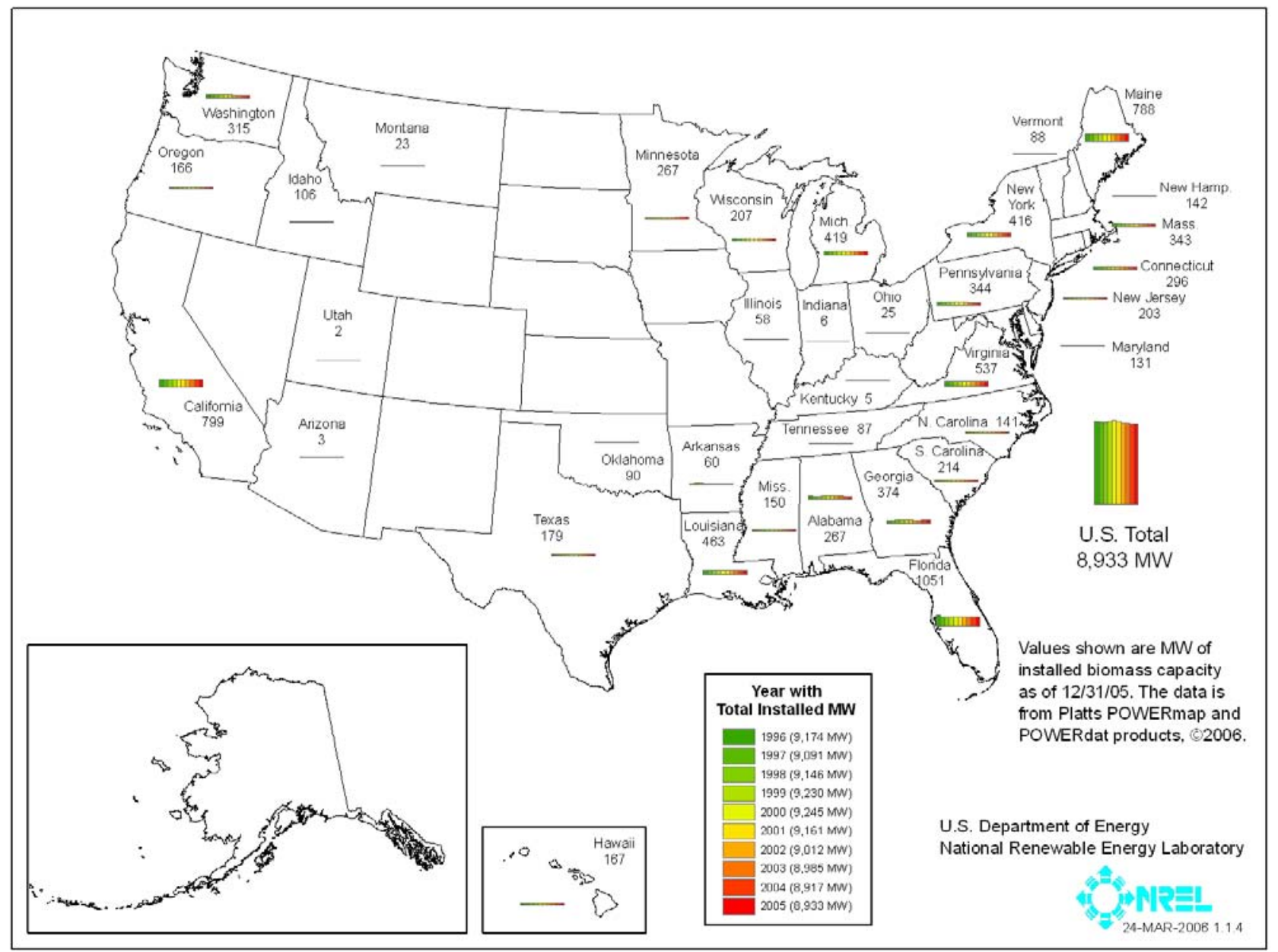

Figure 13.2. Installed Biomass Generating Capacity 


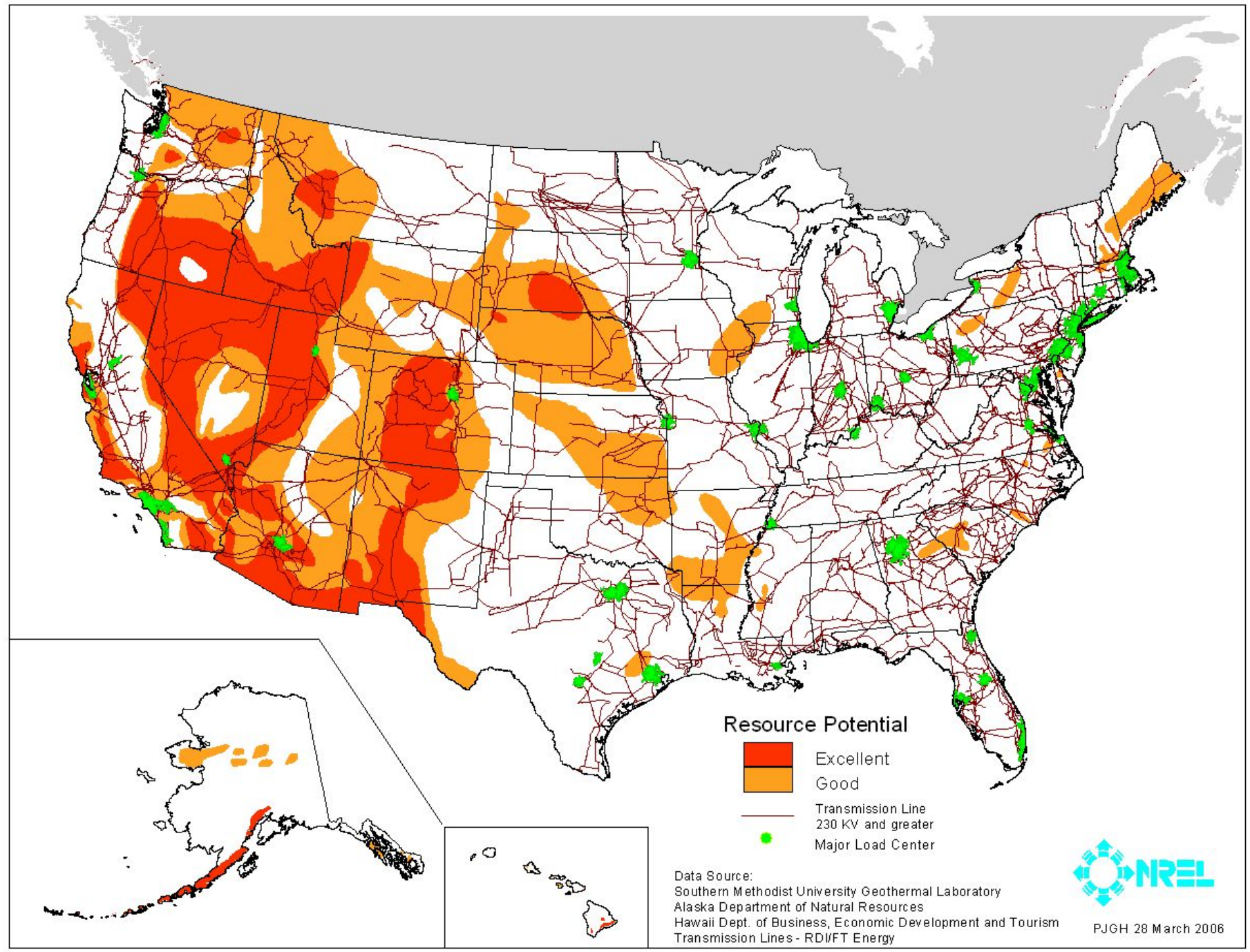

Figure 13.3. Geothermal Resources, Transmission, and Load Centers 


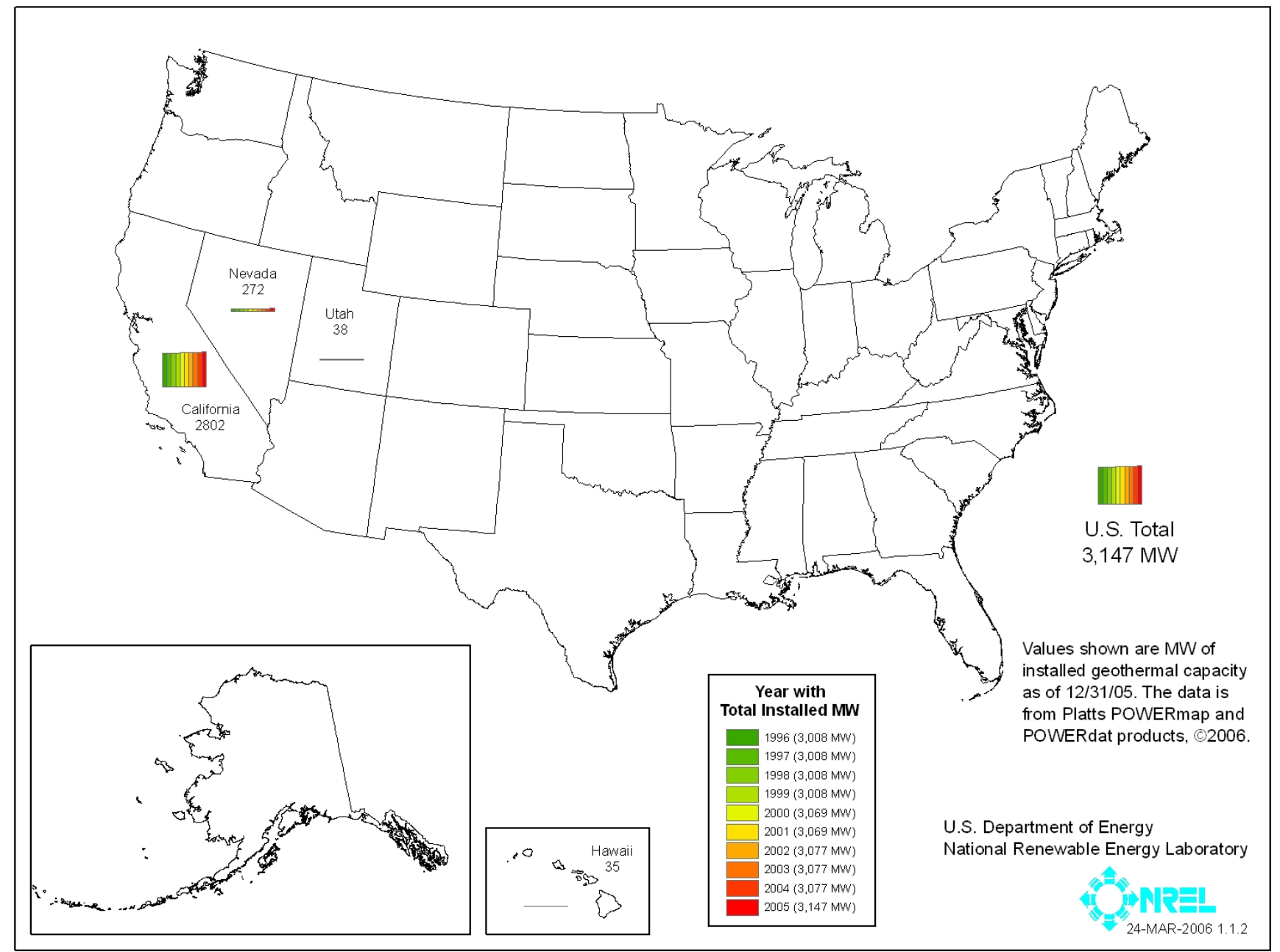

Figure 13.4. Installed Geothermal Generating Capacity 


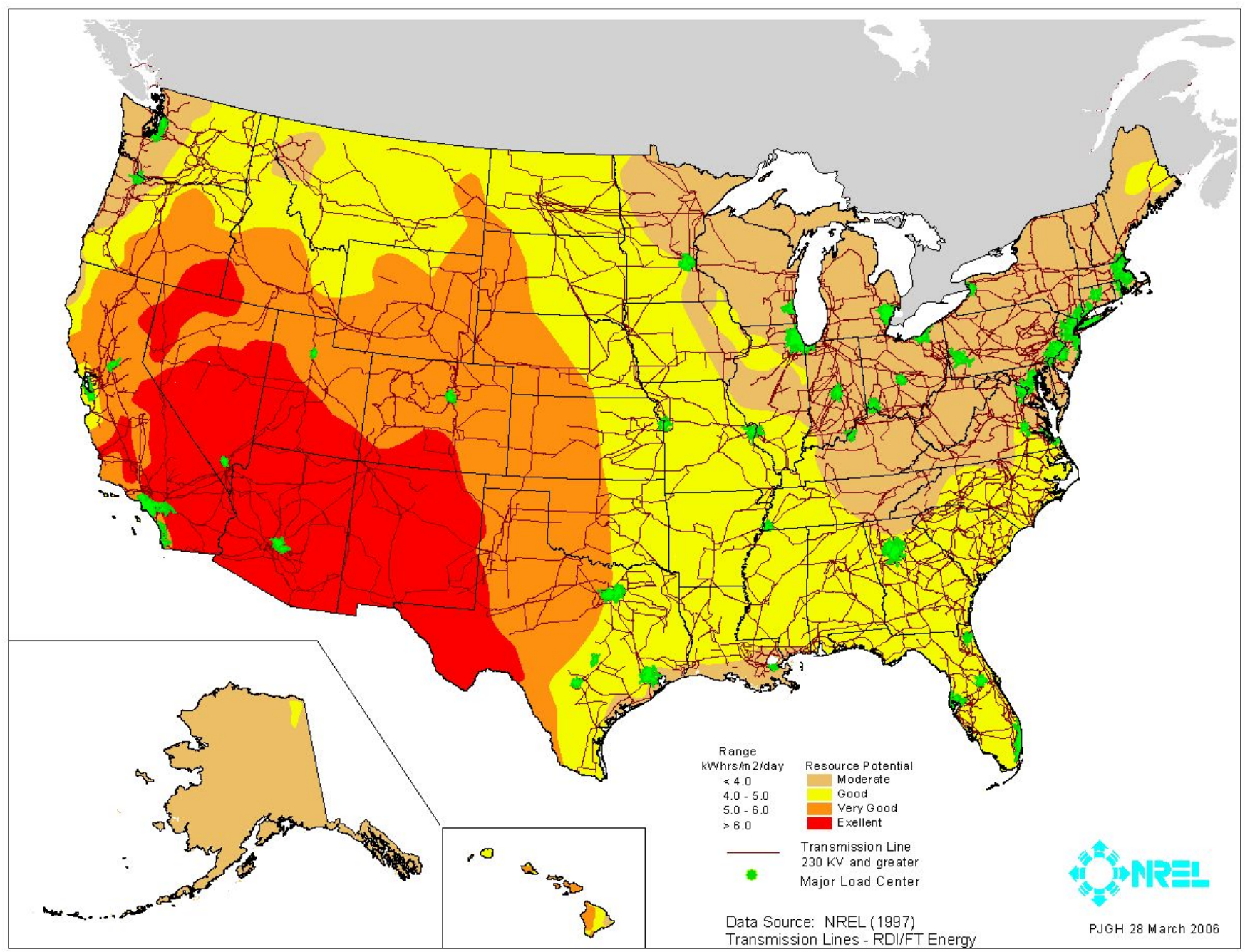

Figure 13.5. Direct Normal Solar Resources, Transmission, and Load Centers 


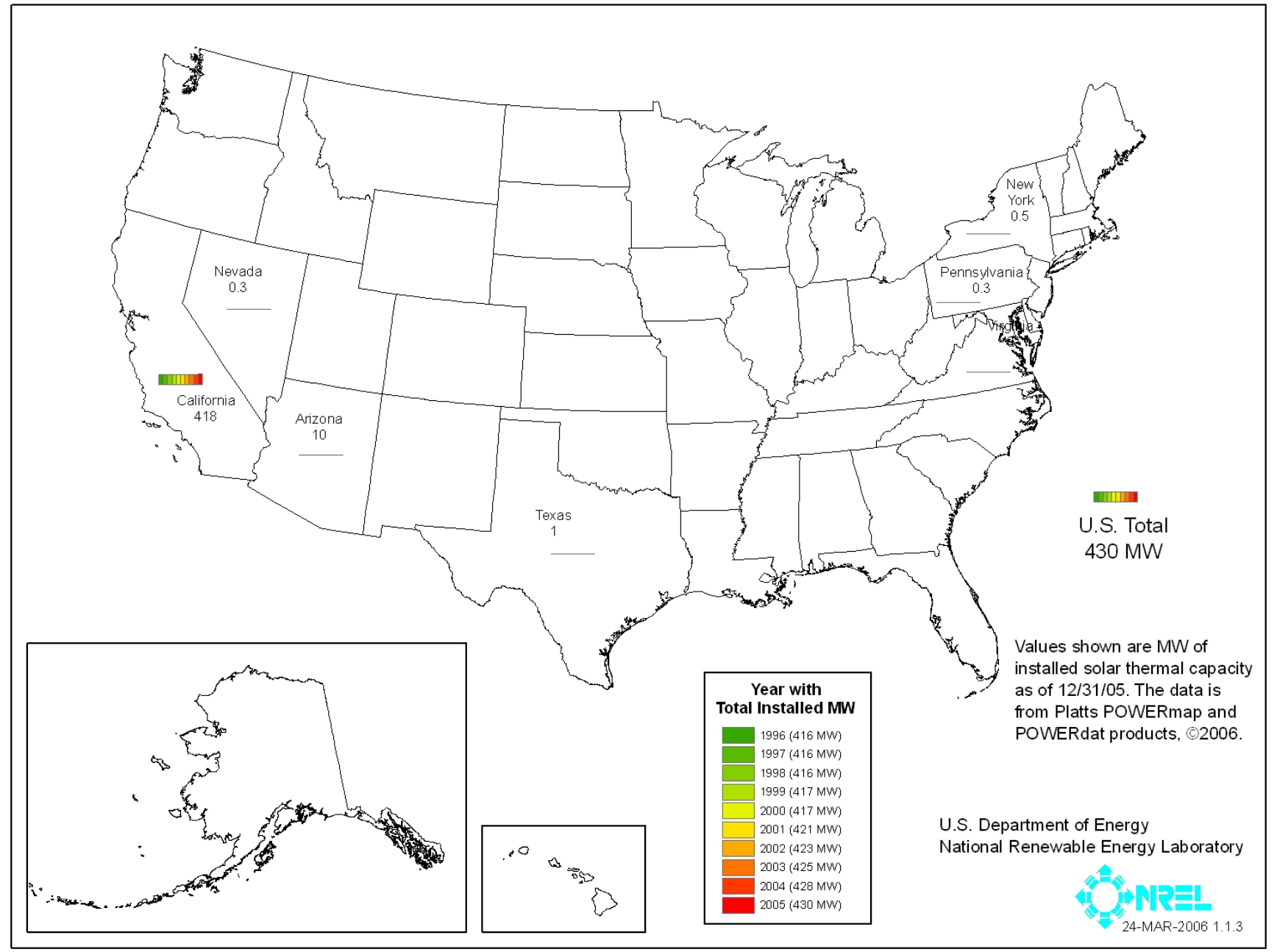

Figure 13.6. Installed CSP Generating Capacity 


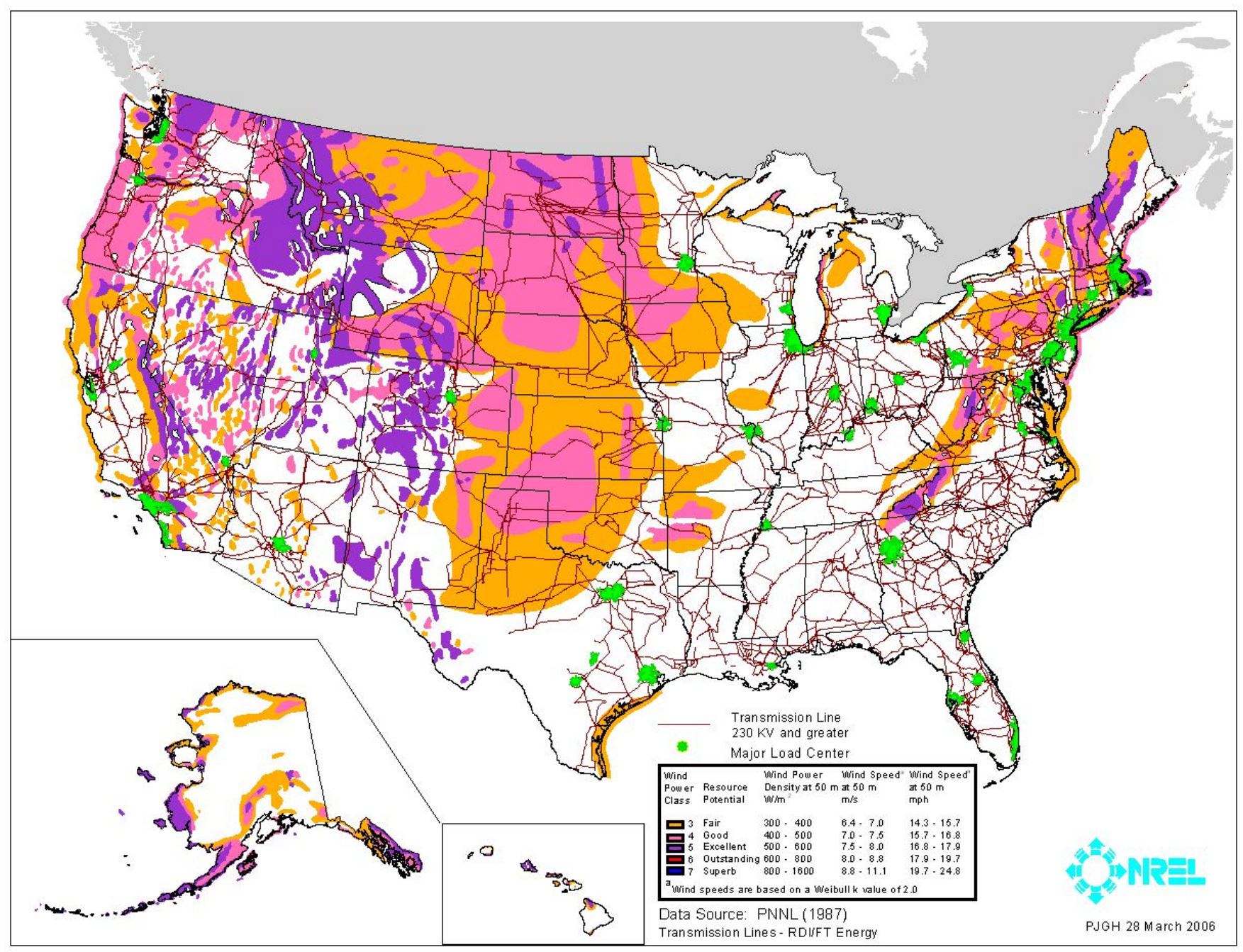

Figure 13.7. Wind Resources, Transmission, and Load Centers 


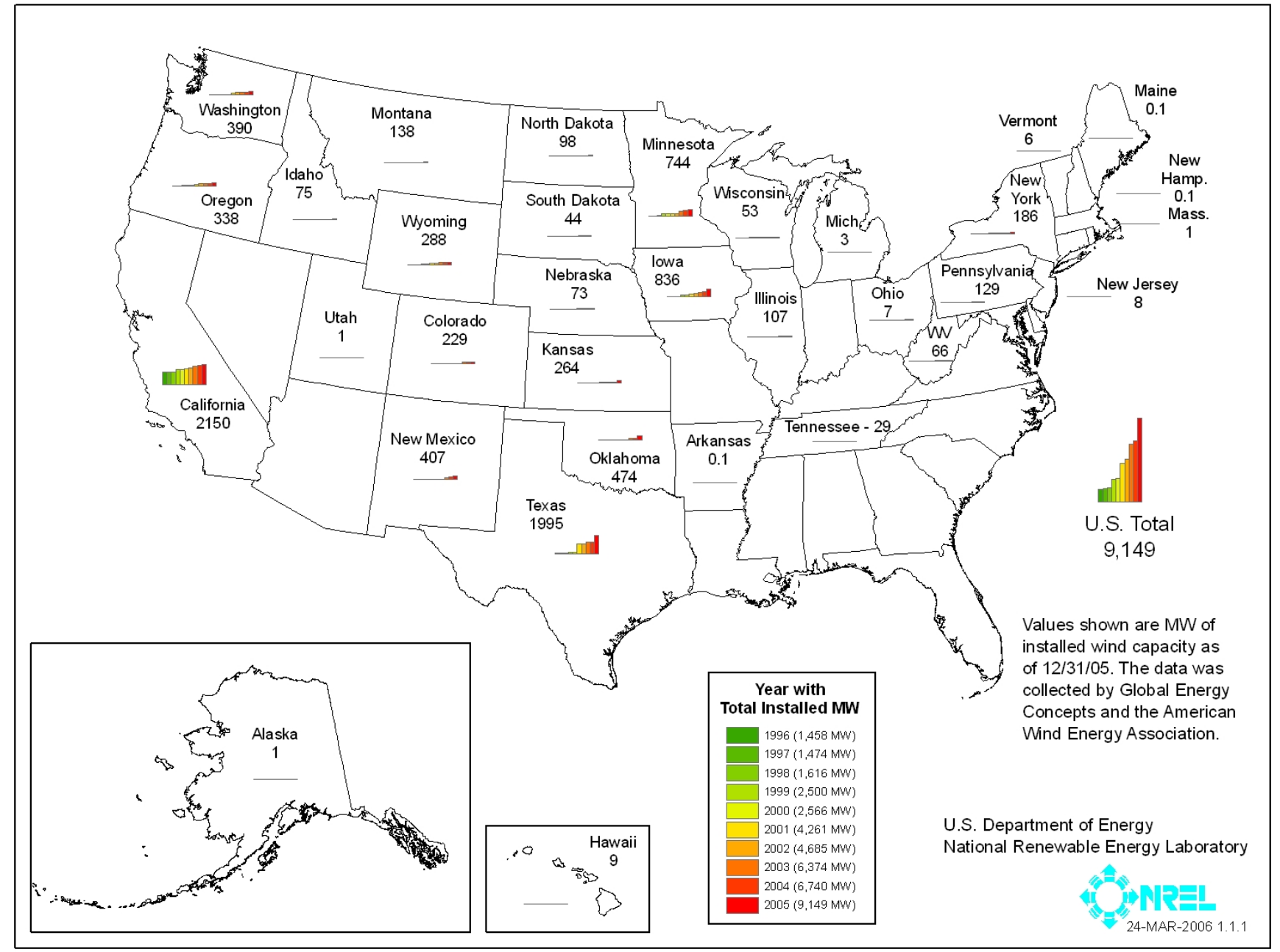

Figure 13.8. Installed Wind Generating Capacity 


\section{REPORT DOCUMENTATION PAGE}

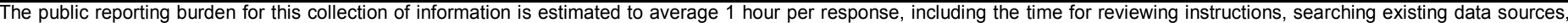

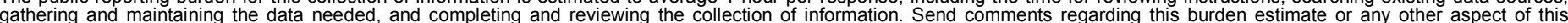

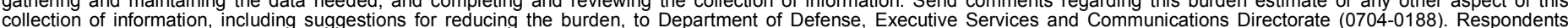

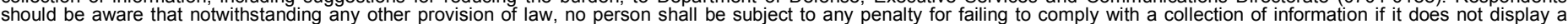

should be aware that notwithstandin

PLEASE DO NOT RETURN YOUR FORM TO THE ABOVE ORGANIZATION.

\begin{tabular}{l|l|l|} 
1. REPORT DATE $(D D-M M-Y Y Y Y)$ & 2. REPORT TYPE & 3. DATES COVERED (FrOm - TO)
\end{tabular}

August 2006

Technical Report

4. TITLE AND SUBTITLE

Power Technologies Energy Data Book_Fourth Edition

5a. CONTRACT NUMBER

DE-AC36-99-G010337

5b. GRANT NUMBER

5c. PROGRAM ELEMENT NUMBER

6. AUTHOR(S)

Compiled by Jørn Aabakken

5d. PROJECT NUMBER

NREL/TP-620-39728

5e. TASK NUMBER

WUA3.1000

5f. WORK UNIT NUMBER
7. PERFORMING ORGANIZATION NAME(S) AND ADDRESS(ES)

National Renewable Energy Laboratory

1617 Cole Blvd.

Golden, CO 80401-3393
8. PERFORMING ORGANIZATION REPORT NUMBER

NREL/TP-620-39728

9. SPONSORING/MONITORING AGENCY NAME(S) AND ADDRESS(ES)

10. SPONSOR/MONITOR'S ACRONYM(S) NREL

11. SPONSORING/MONITORING AGENCY REPORT NUMBER

12. DISTRIBUTION AVAILABILITY STATEMENT

National Technical Information Service

U.S. Department of Commerce

5285 Port Royal Road

Springfield, VA 22161

\section{SUPPLEMENTARY NOTES}

\section{ABSTRACT (Maximum 200 Words)}

This report, prepared by NREL's Strategic Energy Analysis Center, includes up-to-date information on power technologies, including complete technology profiles. The data book also contains charts on electricity restructuring, power technology forecasts, electricity supply, electricity capability, electricity generation, electricity demand, prices, economic indicators, environmental indicators, and conversion factors.

\section{SUBJECT TERMS}

data book; power technologies; electricity restructuring; power technology forecasts and comparisons; electricity supply; electricity capability; electricity generation; electricity demand; prices; economic indicators; environmental indicators; conversion factors; Jørn Aabakken

\begin{tabular}{|l|l|l|l|l|}
\hline \multicolumn{3}{|l|}{ 16. SECURITY CLASSIFICATION OF: } & 17. LIMITATION \\
OF ABSTRACT & 18. & $\begin{array}{c}\text { NUMBER } \\
\text { OF PAGES }\end{array}$ \\
\hline $\begin{array}{l}\text { a. REPORT } \\
\text { Unclassified }\end{array}$ & $\begin{array}{c}\text { b. ABSTRACT } \\
\text { Unclassified }\end{array}$ & $\begin{array}{c}\text { c. THIS PAGE } \\
\text { Unclassified }\end{array}$ & $\begin{array}{c}\text { UL } \\
\end{array}$ &
\end{tabular}

19a. NAME OF RESPONSIBLE PERSON

19b. TELEPHONE NUMBER (Include area code) 